\title{
A taxonomic revision of Araceae tribe Potheae (Pothos, Pothoidium and Pedicellarum) for Malesia, Australia and the tropical Western Pacific
}

\author{
P.C. Boyce and A. Hay
}

\begin{abstract}
Boyce, P.C. ${ }^{1}$ and Hay, A. ${ }^{2}\left({ }^{1}\right.$ Herbarium, Royal Botanic Gardens, Kew, Richmond, Surrey, TW9 3AE, U.K. and Department of Agricultural Botany, School of Plant Sciences, The University of Reading, Whiteknights, P.O. Box 221, Reading, RS6 6AS, U.K.; '2Royal Botanic Gardens, Mrs Macquarie's Road, Sydney, NSW 2000, Australia) 2001. A taxonomic revision of Araceae tribe Potheae (Pothos, Pothoidium and Pedicellarum) for Malesia, Australia and the tropical Western Pacific. Telopea 9(3): 449-571. A regional revision of the three genera comprising tribe Potheae (Araceae: Pothoideae) is presented, largely as a precursor to the account for Flora Malesiana; 46 species are recognized (Pothos 44, Pothoidium 1, Pedicellarum 1) of which three Pothos (P. laurifolius, P. oliganthus and P. volans) are newly described, one (P. longus) is treated as insufficiently known and two (P. sanderianus, P. nitens) are treated as doubtful. Pothos latifolius L. is excluded from Araceae [= Piper sp.]. The following new synonymies are proposed: Pothos longipedunculatus Ridl. non Engl. = P. brevivaginatus; $P$. acuminatissimus $=P$. dolichophyllus; $P$. borneensis $=P$. insignis; $P$. scandens var. javanicus, P. macrophyllus and $P$. vrieseanus $=P$. junghuhnii; $P$. rumphii $=$ P. tener $;$ P. lorispathus $=P$. leptostachyus; $P$. kinabaluensis $=P$. longivaginatus; $P$. merrillii and $P$. ovatifolius var. simalurensis $=P$. ovatifolius; $P$. sumatranus, $P$. korthalsianus, $P$. inaequalis and $P$. jacobsonii $=P$. oxyphyllus. Relationships within Pothos and the taxonomic robustness of the satellite genera are discussed. Keys to the genera and species of Potheae and the subgenera and supergroups of Pothos for the region are provided. All species are illustrated.
\end{abstract}

\section{Contents}

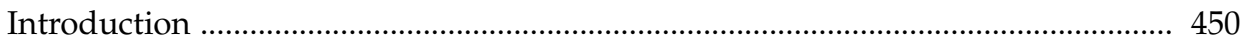

Life form and shoot architecture .............................................................................. 451

Reproductive phase architecture and informal infrageneric classification ............ 454

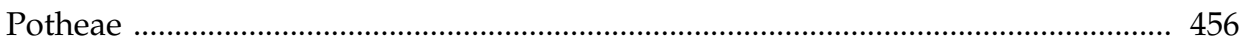

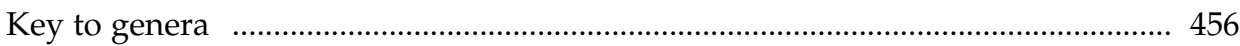

Key to subgenera and supergroups of Pothos …………………………………... 456

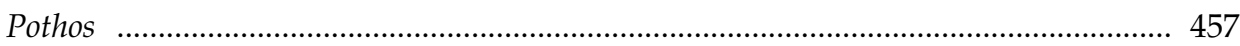

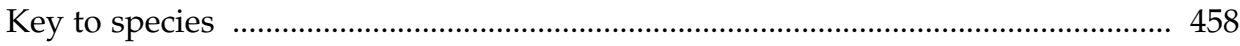

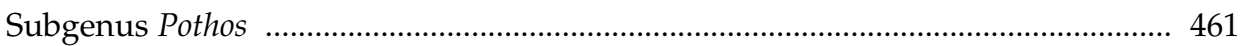

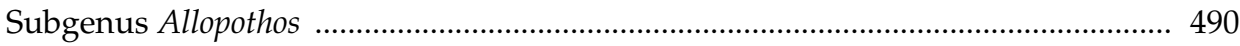

Pedicellarum …........................................................................................................ 554

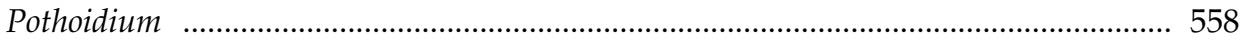




Insufficiently known species
Doubtful species .
Newly excluded species
Previously excluded species
Acknowledgments
Leferences

\section{Introduction}

The tribe Potheae (sensu Mayo et al. 1997) is a palaeotropical and palaeosubtropical assemblage of three very similar, possibly inseparable, predominantly forest-dwelling root-climbing lianescent genera. Besides Pothos L. (the largest genus, with 56 species), the other genera, both unispecific, are Pothoidium Schott and Pedicellarum M. Hotta. The tribe is the only Old World member of the subfamily Pothoideae, which otherwise includes neotropical Anthurium Schott, the largest genus in the Araceae.

Pothos species are subtropical and tropical and distributed from Madagascar to Western Oceania (east to Vanuatu), and China (north to Hubei) to Australia (south to eastern Queensland and eastern New South Wales). The most species and greatest morphological diversity are met with in Indomalesia and concentrated on Borneo. Pedicellarum is endemic to Borneo; Pothoidium is distributed through Maluku, Sulawesi and the Philippines.

Linnaeus $(1753,1763)$ treated Pothos as a genus of climbing aroids with bisexual flowers. Subsequently many climbing (and some non-climbing) aroids were included to form a widely heterogeneous assemblage. Early in the 19th century Schott recognized that Pothos was 'unnatural' as then defined, and in a series of papers (Schott 1832, 1856-1857, 1860) redefined bisexual-flowered aroid genera, at the same time erecting Pothoidium (Schott 1857). The modern circumscription of Pothos is essentially that of Schott.

Schott (1856-1857) established two subgenera, Pothos ('Eupothos') and Allopothos based on branching architecture, leaf shape and inflorescence presentation. Engler (1905) further subdivided Schott's subgenera (calling them sections) into seven series based on inflorescence and flowering shoot characters. While accepting Schott's subgenera, no attempt is made here to formally follow Engler's series as there is rather little overlap between that classification and ours. However, Allopothos (sensu Engler) comprises two distinct groups, those with a spadix of congested flowers (here termed the 'Allopothos supergroup') and those with scattered flowers (the 'Goniurus supergroup'). Recognition of these at an informal level is convenient for the purposes of aiding identification. Current molecular work by P.B. may illuminate whether or not these groups are natural.

The last full revision of Pothos and Pothoidium was that of Engler (1905). Since then several regional reviews have been published (e.g., Li 1979; Sivadasan 1982; Nicolson 1988). This is the third paper in a series intended to complete an alpha-taxonomy of the genus. Revisions of the species for New Guinea, Solomon Islands and Australia (Hay 1995) and Thailand and Indochina (Boyce 2000) have been published and others are being prepared for each of India and the western Himalaya, and Madagascar. 


\section{Life form and shoot architecture}

All species of Potheae are root-climbers (sensu Schimper 1903). Although they are frequently referred to as epiphytes on herbarium labels, no species is yet known to be a true epiphyte. However, it is nearly impossible to ascertain whether the plants remain in contact with the ground throughout their life cycle or whether for at least some of the time they lose contact with the ground, i.e. that they are hemi-epiphytes (see Croat 1990: 11; Putz \& Holbrook 1986). Part of the problem with life-form observations is that it is seldom easy to trace a mass of interlaced adherent stems back to a single source of ground contact and virtually impossible to ascribe the points of ground contact to a particular time in the plant's development.

Mature plants of Pothos display an at times bewildering range of shoot architecture. To date very few field observations have been made but from what has been done it is clear that some potentially useful systematic characters are present. Pothos scandens, P. grandis (subgen. Pothos), P. insignis, P. ovatifolius ('Allopothos supergroup') and $P$. curtisii ('Goniurus supergroup'), are the only species for which tolerably comprehensive shoot architecture observations exist and from which the following summary can be made.

In common with many Araceae lianes (see Schimper 1903: 193), species of tribe Potheae display temporal and spatial differentiation of shoot function with corresponding phases of shoot architecture (see Blanc 1977a \& b, 1978, 1980). All five Pothos species investigated (and Pothoidium and Pedicellarum) have at least five phases of shoot architecture (Fig. 1). A sixth, reiterative phase has been observed in some species.

1. On germination (Fig. 1A) a monopodial leafless (minute cataphylls present) threadlike, shade-seeking (skototropic; see Strong \& Ray 1975) creeper (eocaul) is produced.

2. Once this shoot begins to climb (Fig. 1B) a monopodial, leafy (shingling or not; see Madison (1977) and Boyce \& Poulsen (1994)), juvenile phase develops.

3. This in turn (Fig. 1C) leads to a monopodial, leafy, adherent sterile mature phase.

4. Sympodial, usually free, fertile shoots arise from the sterile mature phase (Fig. 1D).

5. Both mature sterile and fertile shoots can give rise (Fig. 1E) to a terminal extension consisting of a monopodial foliage-leafless flagelliform foraging shoot whose function appears to be to propagate the individual vegetatively by seeking and colonizing suitable climbing surfaces. These foraging shoots can arise in a variety of positions but are most often seen at the tips of free or adherent branches.

6. A reiteration phase may invigorate the plant by re-enacting phases 3 and 4 .

These phases are described in more detail below. Preliminary investigations of Pothos shoot architecture can be found in Boyce \& Poulsen (1994), Boyce \& Nguyen (1995), Boyce \& Hay (1998) and Boyce (2000).

\section{Establishment - phases 1 and 2}

The eocaul is capable of extending for a considerable distance along the forest floor and although the green stem is presumably capable of photosynthesis, at least in the initial stages it appears to depend partly on food reserves in the large seeds. Field observations suggest that the function of the eocaul is to locate a climbing host on which to establish juvenile shoots. It is apparent that once this function is satisfied the eocaul soon withers. The question is unanswered whether the eocaul always dies before the juvenile shoot sends down feeder roots and re-establishes contact with the ground or whether there is a period when the plant is separated from the ground. 
If the latter, then many Pothos species should be classed as secondary hemi-epiphytes (see Putz \& Holbrook, 1986).

Once a suitable vertical surface is encountered, the shoot alters its mode of growth and attaches itself to the substrate by means of short clasping roots arising from either the nodes or internodes; it can therefore be termed a root-climber (see Schimper 1903). At this stage the juvenile shoot also begins to produce foliage leaves. In P. scandens and $P$. grandis (subgen. Pothos) these are similar to adult leaves in appearance, although more congested and smaller; these species are thus homeophyllous. Pothos curtisii and P. ovatifolius (subgen. Allopothos) produce a juvenile root-climber with sub-orbicular imbricating leaves arranged in the manner of the tiles or shingles of a roof ('shingleclimber') and of very different appearance to leaves produced later in the life cycle; these species are thus heterophyllous. Mode of establishment is not known for P. insignis (subgen. Allopothos).

Subsequent growth and maturation - phases 3 and 4

Initially all branches produced are adherent. In all species observed, growth can continue in this manner for a considerable time, the adherent shoots climbing high into the canopy (where conditions permit), giving rise to branches from older lower portions, but usually not branching distally unless the shoot tip is damaged. These adherent stems are referred to as 'mature sterile' in the descriptions to follow. In $P$. scandens and $P$. grandis, by the time the plant has reached $2-3 \mathrm{~m}$ in height, nonadherent irregularly sympodial (i.e. terminating without flowering) side branches have usually begun to develop. These branches are plagiotropic, often repeatedly branching to form extensive curtains of foliage pendent under their own weight, and are referred to here as fertile shoots. It is from the leaf axils of these plagiotropic branches that the flowering shoots arise. The juvenile stage of $P$. curtisii behaves similarly to that of $P$. scandens, the major difference being that the shingle growth is of limited duration (usually climbing to no more than $3 \mathrm{~m}$, often considerably less) before the plant abruptly begins producing leaves of the adult form. That transformation is often accompanied by extensive branching, with both adherent and free shoots arising, and the plant often comes to form a mass of interlacing branches ('hammock'). Pothos ovatifolius conforms to the basic pattern but needs to reach a far greater height before the onset of the production of flowering shoots; it is seldom found in flower lower than $5 \mathrm{~m}$, and frequently reaches the tops of tall trees $(20 \mathrm{~m}+)$ before the onset of flowering.

Foraging - phase 5

The sterile mature phase occasionally transforms terminally into a foraging flagellum with a few leaf-like cataphylls and reduced foliage-leaves at first but soon becoming naked with slightly prominent nodes up to $10 \mathrm{~cm}$ distant. This stem forages for several metres until a suitable climbing surface is encountered and does not branch unless damaged apically when it then branches from the nearest healthy node. The foraging stem occasionally roots sparsely from the nodes but always roots prolifically on resumption of the climbing habit. Occasionally fertile mature shoots transform terminally into a foraging flagellum.

Reiteration - phase 6

A possible sixth phase, a modified version of the sterile mature growth, has been observed in $P$. scandens, $P$. macrocephalus, $P$. repens, $P$. chinensis and Pothoidium lobbianum. In these species (and undoubtedly others also) the sterile mature growth phase occasionally produces enormously robust lateral branches in which the leaves, while of conventional shape and size, are tightly imbricated and not spreading. These branches are also notable for the mass of adherent roots that arise from them. The 
factors triggering this modified growth phase are not known. It might represent another form of foraging shoot and based on observations of P. repens in Vietnam, Boyce \& Nguyen (1995) speculated that these reiteration shoots might serve as a means to rejuvenate ageing plants in which the quantity of high-climbing stems had become too great for the functioning root mass.

\section{Architectural differentiation between subgenera of Pothos}

Main architectural patterns are shared between the genera of Potheae and the subgenera of Pothos. However there is some incomplete architectural differentiation of the subgenera of Pothos.

\section{Subgenus Pothos}

All species investigated $(P$. scandens, $P$. repens, $P$. longipes, $P$. chinensis, $P$. grandis) pass through an eocaul phase. While the eocaul is not known for all species in the subgenus, for those where it is known it alters into a climber with closely arranged or nearly overlapping leaves of much the same shape as those of the mature growth phases. The eocaul phase appears to be monopodial but also produces simple branching systems by reiteration (sensu Hallé et al. 1978). The transition between the seedling and sterile mature phases is gradual with leaves becoming progressively larger. The mature sterile phase is a densely leafy, later naked, appressed monopodial climber rooting copiously from the nodes. The sterile mature growth phase does not branch terminally unless damaged whereupon it reiterates from a node usually some distance back from the damaged apex.

At some point the sterile mature phase begins to produce fertile mature shoots from lateral buds in the leaf axil. These fertile shoots are sympodial, of varying determinate lengths, and often branch to several orders from lateral buds. They are generally moderately leafy, later becoming naked below. Fertile mature shoots eventually produce much-abbreviated lateral shoots consisting of a minute prophyll and one to several cataphylls and terminate in one to several sequential or more or less synchronously produced inflorescences.

\section{Subgenus Allopothos}

Once a climbing surface is reached by the eocaul all but one ( $P$. brassii) species of this subgenus investigated produce a distinctive shingle climber bearing ovate to lanceolate, almost sessile, distichously arranged leaves overlapping in the manner of roof tiles. This phase is closely attached to the substrate by roots arising from the nodes and occasionally produces geotropic feeder roots that reach the ground. The shingle phase eventually undergoes an abrupt transformation when adult leaves are produced with long petioles and lanceolate to elliptic laminae. The sterile mature shoots continue growth and often branch repeatedly from the lower parts, especially in P. luzonensis (Goniurus supergroup). Sterile mature shoots are often scandent, rooting at distant nodes and occasionally form hammocks (extensively branched aerial stem masses) in the canopy. Eventually sterile mature stems branch from below the leaf (or node if the stem is already leafless), giving rise to sympodial fertile shoots. These fertile shoots, although initially produced from the mature sterile stem, later themselves give rise to new fertile (enrichment) shoots that are produced from post fertile portions, usually the older mid-portions, the whole structure eventually forming a much-branched system. Each plant may bear many such systems and each is capable of producing a succession of inflorescences. The length of these individual branches and the degree of leaf development varies between species groups. 


\section{Reproductive phase architecture and informal infrageneric classification}

Architecture of the flowering phase is very variable in the Potheae, and we have used it here as the basis for a preliminary classification below subgenus level. Here we combine an outline of infrageneric classification with summarised descriptions of reproductive phase architecture. Although no molecular studies have been published as yet, such work is underway by the senior author (P.B.) that may test these groupings. The species represented in each group are listed below (species occurring outside the review region are in square brackets).

\section{Subgenus Pothos}

P. scandens group (P. scandens)

Solitary inflorescences are borne terminally on non-reiterating short lateral flowering shoots bearing cataphylls but no foliage leaves and arising in the axils of most leaves of a flowering branch. They flower synchronously and each fertile branch seems to function as an integrated compound inflorescence. Unispecific group with an IndoWest Malesian distribution (extending to Madagascar).

P. junghuhnii group (P. clavatus, P. cylindricus P. gracillimus, P. hellwigii, P. junghuhnii, P. longipes, P. macrocephalus, P. papuanus, P. versteegii, P. zippelii), [P. chinensis, P. gigantipes, $P$. grandis, P. hookeri, P. kerrii, P. pilulifer $]$

Inflorescences few and irregularly positioned. All species have rather large scattered inflorescences that seem to function as separate 'flowers'. Fertile portion of spadix may either be sessile (P. clavatus, P. gracillimus, $P$. hellwigii, P. papuanus, $P$. versteegii, $P$. zippelii) or stipitate (P. junghuhnii, P. grandis, P. gigantipes, P. kerrii, P. pilulifer, P. hookeri, P. macrocephalus, P. chinensis). A geographically widespread group with species from northern Vietnam (P. grandis) to Papuasia (P. papuanus).

$P$. repens group [P. repens]

Fertile shoots borne terminally or from several distal leaf axils on long plagiotropic or pendent sterile mature shoots. Central and north Indochina, southern China (including Hainan and Hong Kong).

\section{Subgenus Allopothos}

Allopothos supergroup

Spadix with congested flowers.

P. tener group (P. tener, P. dolichophyllus, P. ovatifolius, P. leptostachyus)

Inflorescences erect, large, carried on plagiotropic leafy (rarely on cataphyllary), shoots, arising from upper parts or tips of sterile mature stems. Widespread from Thailand through Malesia to the tropical western Pacific.

P. barberianus group (P. atropurpurascens, P. barberianus, P. brevivaginatus, P. englerianus, P. kingii, P. lancifolius, P. longivaginatus, P. mirabilis, P. philippinensis, P. salicifolius, P. volans and P. wallichii), [P. crassipedunculatus, P. thomsonianus]

Inflorescences held beneath the shoot on deflexed peduncles or on long, arching peduncles. Disjunct between the Indian subcontinent and West Malesia.

P. oxyphyllus group (P. brassii, P. brevistylus, P. inaequilaterus, P. laurifolius, and P. oxyphyllus)

Solitary to few erect small inflorescences usually on foliage-leafless (or on leafy shoots). Disjunct between West Malesia and Australia. As well as being geographically disjunct, Australian Pothos brassii somewhat differs architecturally in only flowering 
terminally on leafy shoots, although its inflorescences match well those of, e.g., $P$. brevistylus. Its inclusion here is very provisional.

\section{P. insignis group (P. insignis)}

Pothos insignis is remarkable in producing inflorescences carried on greatly elongated robust orthotropic or diageotropic perennial clinging fertile shoots clothed with large inflated cataphylls and arising from lower, often leafless, parts of sterile mature stems. These shoots are interpreted here as a specialized type of synflorescence (see Boyce \& Poulsen 1994). The fertile shoots are morphologically similar to the sixth vegetative shoot phase noted for subgen. Pothos and Pothoidium. This is an architecturally isolated group with no clear links to other groups. Borneo and Southern Philippines (Palawan).

P. polystachyus group (P. polystachyus, P. cuspidatus, and P. falcifolius)

Inflorescences carried on a plagiotropic or pendent, sympodial, much branched ?perennial cataphylliferous branches. East Malesia.

Goniurus supergroup (P. beccarianus, P. curtisii, P. luzonensis, P. motleyanus, P. oliganthus), [P. armatus, P. remotiflorus]

Spadix with scattered flowers. Inflorescences carried on much abbreviated stems clothed in minute cataphylls and arising from the mid-parts (rarely the tips) of sterile mature stems. In P. curtisii these lateral shoots arise from beneath the leaf axil (or node) and are elaborated by sympodial branching into leafless, sometimes highly complex, compact or lax synflorescences bearing two to many inflorescences simultaneously, or sometimes single inflorescences in series. Synflorescences are usually borne along or at the end of leafy branches or, more rarely on older leafless parts of the stem. Disjunct between the Indian Subcontinent, West Malesia and the Philippines.

\section{Pedicellarum}

The Goniurus supergroup (and in particular P. oliganthus) is of interest since it forms a 'bridge' between Pothos and Pedicellarum. The floral characters used to maintain Pedicellarum (latrorse anther dehiscence, fused perigon elements and the presence of a 'receptacle' in Pedicellarum) all occur in various species of the Goniurus supergroup, although not all in one species. Considering the characters cited above, Pedicellarum would appear to belong in the Goniurus supergroup. [A combination for this species in Pothos was made by Grayum $(1984: 64 ; 1992)$ but it was not effectively published].

It seems reasonable to suggest that either Pedicellarum should be merged into a somewhat expanded concept of Pothos, or species comprising the Goniurus supergroup should be removed from Pothos and merged with Pedicellarum. In the latter case, the generic name Goniurus C. Presl would have priority. A decision will be made in the light of molecular studies currently being carried out.

\section{Pothoidium}

Pothoidium has functionally unisexual spadices arranged seemingly in panicles and maturing sequentially. The structure of the fertile shoots is not yet clearly understood, however. It is possible that they are developed by the reduction of all the leaves of a leafy fertile shoot system to minute prophylls and cataphylls and that the panicle-like synflorescence is hence to be regarded as an aggregate structure. Pothos repens and Pothoidium are vegetatively almost identical. Depauperate flowering specimens of Pothoidium greatly resemble robust plants of $P$. repens. Interpretation of Pothoidium inflorescences suggests that $P$. lobbianum is functionally dioecious. 'Male' spadices have flowers with prominently visible anthers and an apparently sterile ovary. 'Female' spadices have flowers with a large unilocular fertile ovary and no stamens. Flowers of Pothos species are always bisexual with a trilocular ovary. 
It is tempting to regard Pothoidium as a derived offshoot of subgen. Pothos in which functional dioecy has arisen. Nevertheless there is some geographical disjunction between Pothoidium (Moluccas, Sulawesi, Philippines, and Taiwan) and the putatively related species in subgen. Pothos (P. repens, northern Indo-China, SW China). The nature of the relationship of Pothoidium to Pothos may also be made clearer by current molecular studies.

\section{Potheae}

Potheae Engl. Nova Acta Acad. Leopold.-Carol. 39: 140 (1876) ('Pothoeae') \& in A. \& C. DC, Monogr. Phan. 2: 78-94 (1879) ('Pothoeae'); Engl. \& Prantl, Nat. Pflanzenfam. T.2, Ab.3: 112-114 (1889); Engl. in Engl., Pflanzenr. 21 (IV.23B): 20 (1905) ('Pothoeae'); Mayo et al., Genera of Araceae, 98 (1997).

Subtribe Pothineae ('Pothoineae') Schott, Prodr. Syst. Aroid., 558 (1860); Engl. in A. \& C. DC, Monogr. Phan. 2: 78-94 (1879).

Shrubby climbing herbs, with tough woody stems, main shoot monopodial, flowering shoots axillary or infra-axillary; leaves distichous; petiole sheath long and often broad, flattened and apically auriculate (reduced in Pedicellarum and Pothos 'Goniurus'); flowers bisexual, rarely functionally unisexual, perigoniate, (2-)3-merous; tepals (4-)6, free or fused; stamens 6, free, pollen monosulcate; ovules 1 per locule, anatropous, stigma sessile, usually umbonate; embryo large, endosperm absent.

Distribution - Three genera, Madagascar to southern China, western Oceania and eastern Australia.

\section{Key to genera}

1a. Ovary 3-locular; locules 1-ovulate; flowering shoot with inflorescences always axillary or infra- axillary, if terminal then inflorescence solitary on a leafy shoot; flowers bisexual ...... 2

1b. Ovary 1-locular; flowering shoots terminating in a branching system of spadices; flowers usually (always?) functionally unisexual

Pothoidium

2a. Flowers sessile; tepals free, very rarely united

Pothos

2b. Flowers pedicellate; tepals connate

Pedicellarum

\section{Key to subgenera and supergroups of Pothos}

1a. Petiole lamina-like, without a sheath and with a slight apical articulation with the lamina, occasionally much reduced. Inflorescences arising in the leaf axils, rarely terminal on shoots subgenus Pothos

1b. Petiole sheathing for much of its length, conspicuously geniculate at the apex. Inflorescences mostly arising from below the leaf axils, or terminally on leafy shoots, rarely in leaf axils .... subgenus Allopothos 2

2a. Spadix with congested flowers arranged in a dense spiral Allopothos supergroup

2b. Spadix with scattered flowers arranged in a loose spiral Goniurus supergroup 


\section{Pothos}

Pothos L., Sp. Pl. (1753) 968 \& edn 2 (1763) 1373-1374, 1675; Schott in Schott \& Endl., Melet. Bot. (1832) 21; Endl., Gen. Pl. 3 (1837) 239; Kunth, Enum. Pl. 3 (1841) 65-66; Schott, Aroideae (1856-1857) 21-25, t.31-56 \& Gen. Aroid. (1858) 95 \& Prodr. Syst. Aroid. (1860) 558-575); Engl. in A. \& C. DC, Monogr. Phan. 2 (1879) 78-94; Benth. \& Hook.f., Gen. Pl. 3(2) (1883) 999; Engl. \& Prantl, Nat. Pflanzenfam. T.2, Ab.3 (1889) 113-114 \& Nat. Pflanzenfam. Nachtr. 1 (1897) 58; Engl. in Engl., Pflanzenr. 21 (IV.23B) (1905) 21-44; Engl. \& Prantl, Nat. Pflanzenfam. Nachtr. 3 (1908) 28; Mayo et al., Genera of Araceae (1997) 98-99, pl.5, 108, a. [- Tapanava Adanson, Fam. 2 (1763) 470, nom. superfl.] - Type: Pothos scandens L.

Goniurus C. Presl, Epimel. Bot. (1851, '1849') 244. — Type: Goniurus luzonensis C. Presl [= Pothos luzonensis (C. Presl) Schott].

[Potha O. Kuntze, Rev. Gen. 2 (1891) 742, orth. var.].

Small to very large, very slender to robust, probably rarely secondarily hemi-epiphytic (see Croat 1990: 11; Putz \& Holbrook 1986), root-climbing, homeo- or heterophyllous, tough, fibrous lianes. Shoots usually clearly differentiated into adherent, physiognomically monopodial (see Boyce 1998, Boyce \& Nguyen 1995, Boyce \& Poulsen 1994, Boyce \& Hay 1998, Boyce 2000, Hay 1995) non-flowering, and free, sympodial or physiognomically monopodial flowering shoots, often highly ramified, arising from the leaf axil (subgen. Pothos) or beneath it (subgen. Allopothos); seedling, where known, a cataphyll-bearing but otherwise leafless, photosynthesising threadlike eocaul; adult plants often producing flagelliform, leafless (cataphyll-bearing), skototropic, foraging shoots; juvenile plants sometimes shingle-leaved (subg. Allopothos; juveniles not described for most species); internodes (except at the beginning of branches) much longer than thick, nodes on free shoots occasionally bearing roots modified into spines. Leaf blades simple, entire, very narrowly lanceolate to broadly ovate, often asymmetrical (subg. Allopothos), with reticulate venation, the primary lateral veins on each side of the midrib traversed by one or more intramarginal veins running \pm from the base and from about midway along the midrib to the apex or first to the distal margins and then to the apex; petiole either with a narrow, \pm clasping sheath and a conspicuous apical geniculum (subg. Allopothos), or broad, flattened and lamina-like with a small apical articulation (subg. Pothos), the leaf then resembling that of some Citrus. Inflorescences solitary (subgen. Pothos) or terminal on leafy branches (subgen. Allopothos), more usually arranged on lateral short shoots bearing cataphylls (subgen. Allopothos), these short shoots usually simple with a single inflorescence, sometimes elaborated by sympodial branching into usually leafless, sometimes highly complex, compact or lax synflorescences bearing two to many inflorescences flowering in series; synflorescences (if present) borne along or at the end of leafy branches, sometimes persisting on older leafless parts of the stem or sometimes arising there. Spathe mostly rather inconspicuous, ovate to lorate or greatly attenuate, opening wide and held away from the spadix, often fully reflexed, green to dirty white or yellow or deep purple. Spadix sessile or stipitate, tapering-cylindrical to spherical. Flowers bisexual, congested to scattered, with a perianth of usually 6 , rarely 4 , free tepals or the perianth completely united and the flowers sunken in pits on the spadix with the perianth resembling a centrally perforated operculum over the pit; stamens 6, rarely 4, with flattened filaments and extrorse anthers, thecae elongate to globose; ovary trilocular, the locules uniovulate, ovules anatropous on an axile placenta at the base of the septum; stigma punctiform, discoid-hemispheric or umbonate, mostly sessile. Fruit a 1-3-seeded berry ripening from dark green through yellow to variously red, individually distinct, very large relative to spadix; seeds large, exalbuminous, testa smooth; embryo macropodal. Pollen monosulcate, ellipsoid- 
oblong, small [mean $21 \mu \mathrm{m}$, range 16-25 $\mu \mathrm{m}$ ], exine foveolate to reticulate or subrugulate, the muri psilate or minutely tuberculate (Grayum 1984, 1992). Chromosomes: $2 \mathrm{n}=24,36$ (Petersen 1989).

Distribution - 56 species distributed from Madagascar to Vanuatu and from China (as far north as Hubei) to Australia (as far south as New South Wales). In Malesia: 37 species.

Habitat - Bole climbing, occasionally lithophytic, root-climbing lianes or rarely secondary hemi-epiphytes in low to upper-mid-elevation tropical or subtropical seasonal to perhumid evergreen forest.

\section{Key to species}

(including the species of Pothoidium and Pedicellarum)

1a. Petiole lamina-like, without a sheath and with a slight apical articulation with the blade, occasionally much reduced; inflorescences arising in the leaf axils, rarely terminal on shoots

b. Petiole sheathing for much of its length, conspicuously geniculate at the apex; inflorescences mostly arising from below the leaf axils, or terminally on leafy shoots

a. Inflorescences several to many, borne in a terminal branching system on either the primary or subsidiary tips of long pendent shoots, lower inflorescences axillary to a foliage leaf, upper ones either subtended by cataphyll or without subtending leaf. Maluku, Sulawesi, Philippines 43. Pothoidium lobbianum

2b. Inflorescences solitary in the leaf axil, rarely terminal on leafy shoots 3

3a. Spadix stipe sharply bent at anthesis, fertile portion of spadix held adjacent to peduncle. Malay Peninsula to Philippines 1. Pothos scandens

3b. Spadix stipe \pm straight at anthesis

4a. Petiole less than one sixth of the length of the blade. New Guinea ...... 7. Pothos versteegii

$4 \mathrm{~b}$. Petiole over one quarter of to exceeding the length of the blade

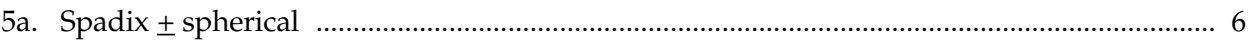

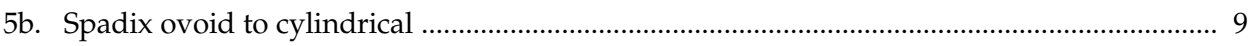

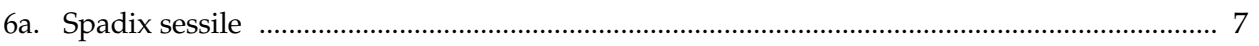

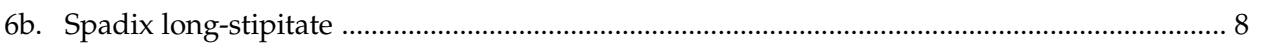

7a. Apex of peduncle abruptly expanded at union with spadix. West New Guinea

7b. Peduncle gradually thickened along its length. New Guinea, Bismarck Archipelago, Solomons

8a. Petiole greatly exceeding the blade; inflorescences arising at all but the basal-most leaf axils of flowering branch; peduncle orange-yellow, stipe pale green and the spathe white. Sumatera (Riau), Thailand (Yala \& Narathiwat), Peninsular Malaysia 6. Pothos macrocephalus

8b. Petiole shorter than to equalling the blade; inflorescences arising from the distal leaf axils of fertile shoots; peduncle and stipe purple, spathe tending to green or purple. Sumatera, Java, Sarawak?

9a. Spadix ovoid 10

9b. Spadix cylindrical 11

10a. Blade very narrowly lanceolate, c. $5 \mathrm{~mm}$ wide; spadix c. $3 \mathrm{~mm}$ diam. New Guinea ................ 
10b. Blade more or less elliptic, c. 1-3 cm wide; spadix c. 7 mm diam. Maluku, New Guinea, Solomons

11a. Spadix stipitate (very rarely sessile); inflorescences arising in the axils mostly of distal leaves of a flowering branch, only rarely terminal on leafy branchlets; petiole usually longer than the blade. Warm temperate to tropical eastern Australia .... 10. Pothos longipes

11b. Spadix sessile; inflorescence terminal or lateral; petiole longer to shorter than the blade. Not in Australia

12a. Inflorescence always terminal on a leafy shoot; spathe lanceolate; petiole usually longer than the blade. Sabah, Sulawesi and the Philippines

11. Pothos cylindricus

12b. Inflorescence usually lateral on a (sometimes sympodially branched) short shoot in distal leaf axils; spathe oblong-ovate to oblong-lanceolate; petiole usually shorter than to equalling the blade. Papuasia

9. Pothos papuanus

13a. Spadix with scattered flowers arranged in a loose spiral 14

13b. Spadix with congested flowers arranged in a dense spiral 19

14a. Flowers stipitate, each with a prominent receptacle; tepals fused, forming a cup. Borneo 42. Pedicellarum paiei

14b. Flowers sessile, lacking a receptacle; tepals free

15a. Spadix 0.4-1.2 cm long; flowers usually 3, seldom more than 5, per inflorescence. Sarawak

15b. Spadix 3.5-19.8 cm long; flowers many per inflorescence 41. Pothos oliganthus

16a. Spadix smooth, glabrous. Philippines (Luzon, Samar) 39. Pothos luzonensis

16b. Spadix roughened or pubescent

17a. Petioles up to $10.5 \mathrm{~cm}$ long with a conspicuous sheath; leaf blades stiffly chartaceous spadix roughened. Sumatera (Sumatera Utara \& Jambi), Thailand (Narathiwat), Peninsular Malaysia, Singapore

38. Pothos curtisii

17b. Petiole up to $5 \mathrm{~cm}$ long, sheath not conspicuous; leaf blades thinly or stiffly coriaceous, spadix pubescent.

18a. Leaf blade stiffly coriaceous, very short ginger-tomentose abaxially, base obtuse to slightly cordate; primary lateral veins arising at $70-85^{\circ}, 2$ intramarginal veins per side, $2-20 \mathrm{~mm}$ from blade margin, arising from just above base of the midrib, remaining \pm parallel to margin, terminating at the tip of the blade. Borneo

40. Pothos motleyanus

18b. Leaf blade coriaceous, glabrous and pale green abaxially, base acute to obtuse. NW Borneo 37. Pothos beccarianus

19a. Peduncle ascending. 20

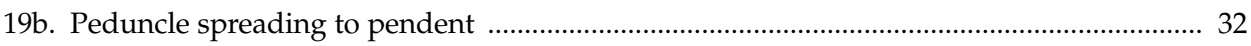

20a. Inflorescences almost always at the tips of leafy shoots....................................................... 21

20b. Inflorescences carried on a climbing, plagiotropic or pendent, sympodial, simple or much branched cataphylliferous branches

21a. Inflorescence small; spathe c. $2 \mathrm{~cm}$ long; spadix, c. $2 \mathrm{~cm}$ long. Australia (NE Queensland)

21b. Inflorescence medium to large; spathe exceeding $2.5 \mathrm{~cm}$ and mostly exceeding $10 \mathrm{~cm}$; spadix exceeding $2.5 \mathrm{~cm}$ and mostly exceeding $5 \mathrm{~cm}$. Not in Australia

22a. Spadix sessile. Philippines

22b. Spadix stipitate

23a. Leaf blade stiffly chartaceous to coriaceous, (3-)8.5-27 × (2.5-)7-27 cm, spreading, oblong ovate to very broadly ovate, oblique, sometimes profoundly so, base broadly rounded to narrowly cordate. Sumatera (P. Simeulue), W Malaysia (P. Tioman), Sarawak, Sabah, Philippines 
23b. Leaf blade chartaceous, oblong-elliptic to ovate-oblong or elliptic, base acute to rounded 24

24a. Peduncle 2.7-5 cm; spathe 2.5-10; stipe $0.8-1.5$, fertile portion of spadix 5-6.5 $\mathrm{cm}$. Thailand (Yala), Sumatera (Aceh), Peninsular Malaysia (Pahang), Borneo

15. Pothos leptostachyus

24b. Peduncle 10-20 cm; spathe 11-27; stipe 2-4, fertile portion of spadix 10-22 cm. Sulawesi, Maluku, New Guinea, Solomon Islands and Vanuatu 12. Pothos tener

25a. Inflorescences carried on simple greatly elongated orthotropic to diageotropic clinging shoots clothed with large inflated cataphylls and arising from lower, often leafless, parts of sterile mature stems. Borneo, Philippines (Palawan) ................................ 33. Pothos insignis

25b. Inflorescences carried on much-branched, moderately elongated, free shoots clothed with leaves or with small, not or barely inflated cataphylls. Sumatera, Peninsular Malaysia, Java, Borneo, Philippines (excluding Palawan). Maluku, New Guinea 26

26a. Leaves glaucous abaxially; spathe fleshy, deep purple, glossy. Brunei Darussalam 31. Pothos laurifolius

26b. Leaves not glaucous abaxially; spathe not fleshy. Borneo, Maluku, New Guinea, Philippines

27a. Inflorescences carried on moderately elongated, free shoots clothed with leaves; stigma with a long slender persistent style. Borneo 30. Pothos brevistylus

27b. Inflorescences carried on much-branched, moderately elongated, free shoots clothed with small, not or barely inflated cataphylls; stigma flat. Sumatera, Peninsular Malaysia, Java, Philippines (excluding Palawan), Maluku, New Guinea

28a. Spadix markedly tapering. Maluku, western New Guinea 36. Pothos falcifolius

28b. Spadix cylindrical. New Guinea, Philippines 29

29a. Spadix sessile. Papua Barat (Jayapura), NE Papua New Guinea (W Sepik) ...................... 30

29b. Spadix sessile or briefly stipitate. Sumatera, Peninsular Malaysia, Java, Philippines ......... 31

30a. Inflorescences multiple, borne on lax (foliage-)leafless sympodial branch systems. NE Papua New Guinea (W Sepik) 35. Pothos polystachyus

30b. Inflorescences solitary or paired, rarely few together. Papua Barat (Jayapura)

31a. Spadix fertile portion $2.5-4 \times 0.2-0.4 \mathrm{~cm}$. Sumatera, Peninsular Malaysia, Java

28. Pothos oxyphyllus

31b. Spadix fertile portion $1-2 \times 0.2-0.4 \mathrm{~cm}$, Philippines 29. Pothos inaequilaterus

32a. Peduncle stout, twisted basally to carry inflorescence beneath the shoot ............................ 33

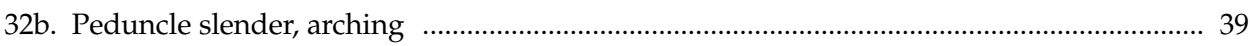

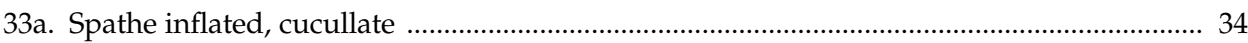

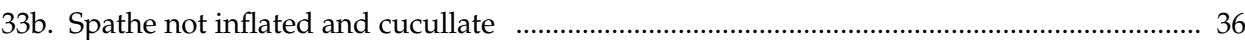

34a. Inflorescence on a foliage-leafless shoot arising below a foliage leaf; spathe $3-4 \mathrm{~cm}$ long. Sumatera ……............................................................................ 20. Pothos englerianus

34b. Inflorescence on a foliage-leafless in the axils of distal leaves, occasionally from such shoots arising (persisting?) on leafless older stems or terminal on leafy shoots; spathe $4-11 \mathrm{~cm}$ long. Not Sumatera

35a. Leaf tip abruptly cuspidate; spathe thin-textured, white, purple-flushed. Borneo

35b. Leaf tip attenuate-mucronate, acute or attenuate; spathe softly-leathery, deep purple inside and out. Thailand (south peninsular), Peninsular Malaysia 22. Pothos kingii 
36a. Peduncle 2-4 cm long; spathe lorate, strongly reflexed, appressed to peduncle. Sumatera, Peninsular Malaysia and Borneo 16. Pothos barberianus

36b. Peduncle $8-45 \mathrm{~cm}$ long; spathe lorate to triangular, reflexed, spreading or erect 37

37a. Peduncle 8-12 cm long; spadix decurrent on peduncle; spathe erect over spadix. Philippines 19. Pothos philippinensis

37b. Peduncle $12-45 \mathrm{~cm}$ long; spadix sessile or briefly stipitate, not decurrent; spathe reflexed to erect

38a. Spathe lorate, strongly reflexed, appressed to peduncle; spadix sessile. Borneo 17. Pothos longivaginatus

38b. Spathe triangular-lanceolate, spreading; spadix briefly stipitate. Sumatera 24. Pothos brevivaginatus

39a. Leaf blade very narrow elongate lanceolate-elliptic, stiffly coriaceous. Peninsular Malaysia

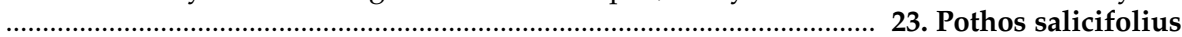

39b. Leaf blade not as above 40

40a. Spathe 19-37 cm long, enormously elongate-lanceolate, drooping and twisting into two or more graceful elongate spirals, base long-decurrent for up to $5 \mathrm{~cm}$ on peduncle. Borneo ....

27. Pothos mirabilis

40b. Spathe not as above 41

41a. Spathe lorate, spreading to weakly reflexing; spadix stipitate (5.2-)6-7.7 cm long. Peninsular Malaysia, Java, Borneo 25. Pothos wallichii

41b. Spathe ovate-triangular to lanceolate; spadix sessile $2-5 \mathrm{~cm}$ long 42

42a. Peduncle $6-7 \mathrm{~cm}$ long, very slender; spathe $4-5 \times 0.9-1.5 \mathrm{~cm}$, broadly ovate-triangularlanceolate, thinly papery; spadix $2-3 \mathrm{~cm}$ long. Sarawak and Brunei Darussalam 26. Pothos volans

42b. Peduncle $1.5-5 \mathrm{~cm}$, stout; spathe $2.5-10$ lanceolate, slightly softly-leathery; spadix $1.5-5 \mathrm{~cm}$ long. Peninsular Malaysia 18. Pothos lancifolius

\section{Subgenus Pothos}

Pothos subgen. Eupothos Schott, Aroideae 1 (1853) 21. - Pothos sect. Eupothos Engl. in A. \& C. DC., Monogr. Phan. 2 (1879) 78. - [Pothos series Scandentes Engl., Pflanzenr. 21(IV.23B) (1905) 22, nom. superfl. pro ser. typ. )]. - Type: Pothos scandens L.

Pothos series Papuani Engl., Pflanzenr. 21(IV.23B) (1905) 22. - Type: Pothos papuanus [Becc. ex] Engl.(lecto selected here). Lectotypifications of these series are based on the typifications implicit in the names Engler used.

Pothos series Loureiriani Engl. Pflanzenr. 21(IV.23B) (1905) 22. - Type: Pothos loureirii Hook. \& Arn. (lecto selected here).

Pothos series Longipedes Engl., Pflanzenr. 21(IV.23B) (1905) 22. - Type: Pothos longipes Schott (lecto selected here).

\section{Pothos scandens L.}

Pothos scandens L., Sp. Pl. (1753) 698 \& Sp. Pl. edn 2 (1763) 1373-1374, 1675; Schott in Schott \& Endl., Melet. Bot. (1832) 21; Endl., Gen. Pl. 3 (1837) 239; Kunth, Enum. Pl. 3 (1841) 65-66; Miq., Flora Ned. Indië 3 (1856) 178; Schott, Aroideae 1 (1856-7) 22, t.33 \& Gen. Aroid. (1858) t.95 \& Prodr. Syst. Aroid. (1860) 563; Engl. in A. \& C. DC, Monogr. Phan. 2 (1879) 84; Hook.f., Fl. Brit. Ind. 6 (1893) 551-552; Engl. in Engl., Pflanzenr. 21 (IV.23B) (1905) 26-27; Ridl., Mat. Fl. Malay Penins. 3 (1907) 48; Koorders, Exkursfl. 
Java, 1 (1911) 251; Ridl, Fl. Malay Penins. 5 (1925) 127-128; Henderson, Malayan Wild Flowers, Monocots (1954) 238-239 not as to Fig.143A; Boyce, Blumea 45 (2000) 180-186, figs 9a, 9b. - Type: Herb. Hermann 4: 39, No. 329 (lecto BM; selected by Suresh et. al. (1983)).

Pothos hermaphroditus (Blanco) Merr., Sp. Blancoanae (1918) 90; Backer \& Bakh.f., Fl. Java, 3 (1968) 104. — Batis hermaphrodita Blanco, Fl. Filip. ed.1 (1837) 791. - Type: Philippines, Luzon, Laguna Prov., Mt Maquiling, Nov 1912, Merrill, Sp. Blanco. No. 57 (K, neo, designated by Boyce (2000: 184)).

[Pothos longifolius C. Presl, Epimel. Bot. (1849) 242; Schott, Aroideae (1856-1857) 22, t.34 \& Prodr. Syst. Aroid.(1860) 563-564; Engl. in A. \& C. DC, Monogr. Phan. 2 (1879) 82-83 \& in Engl., Pflanzenr. 21 (IV.23B) (1905) 25, nom. illeg., non Pothos longifolius Hoffmans., Verz. Pfl. 102: Nachtr. 3 (1826) 53 (Mexico) nec Pothos longifolius Link \& Otto ex Steud., Nom. ed. 2 (1841) 391 (Venezuela). — Type: Philippines, Luzon, Tayabas, Cuming 682 (PRG, holo; iso BM, E, G, K, P)].

Pothos angustifolius C. Presl, Epimel. Bot. (1849) 243; Schott, Aroideae (1856-1857) 21, t. 31 \& Prodr. Syst. Aroid. (1860) 559; Engl. in A. \& C. DC, Monogr. Phan. 2 (1879) 81-82 \& in Engl., Pflanzenr. 21 (IV.23B) (1905) 23-24. - Type: Myanmar, between Moulmine \& Martaban, Helfer sub Herb. East India Co. no. 5944 (holotype not found; iso C, K, L, P).

[Pothos microphyllus C. Presl, Epimel. Bot. (1849) 243 ; Schott, Prodr. Syst. Aroid. (1860) 559-560; Engl. in A. \& C. DC, Monogr. Phan. 2 (1879) 94, nom. illeg., non Pothos microphyllus Hook., Curt. Bot. Mag., (1829) t.2953 (Brazil). — Type: Myanmar, between Moulmine \& Martaban, Helfer sub Herb. East India Co. no. 5942 (PRG, holo; iso K, P)].

Pothos leptospadix de Vriese in Miq., Pl. Jungh. 1 (1851) 105; Schott, Prodr. Syst. Aroid. (1860) 568. - Type: Indonesia, Sumatera, Angkola, near Tobing, Junghuhn s.n. (L, holo).

Pothos scandens L. var. zeylanicus de Vriese, Pl. Jungh. 1 (1851) 103. — Type: Sri Lanka, Splitgerber 27 (L, holo).

Pothos scandens L. var. sumatranus de Vriese, Pl. Jungh. 1 (1851) 103. — Type: Indonesia, Sumatera, Junghuhn s.n. (L, holo).

Pothos roxburghii de Vriese in Miq., Pl. Jungh. (1851) 103; Miq., Flora Ned. Indië 3 (1856) 178-179; Schott, Aroideae (1856) 22 \& Prodr. Syst. Aroid. (1860) 565; Engl. in A. \& C. DC, Monogr. Phan. 2 (1879) 81 \& in Engl., Pflanzenr. 21 (IV.23B) (1905) 24-25; Backer \& Bakh.f., Fl. Java, 3 (1968) 104. [- Pothos longipedunculatus Engl. in Engl., Pflanzenr. 21 (IV.23B) (1905) 27, nom. superfl. pro P. roxburghii - see Notes]. - Type: Bangladesh, Sylhet, Wallich 4435D (L, lecto; selected here).

Pothos chapelieri Schott, Aroideae (1857-1857) 22, t.35 \& Prodr. Syst. Aroid. (1860) 564; Engl. in A. \& C. DC, Monogr. Phan. 2 (1879) 80 \&. in Engl., Pflanzenr. 21 (IV.23B) (1905) 24. - Type: Madagascar, Chapelier s.n. (B十?).

Pothos exiguiflorus Schott, Aroideae (1856-1857) 21, t.41 \& Prodr. Syst. Aroid. (1860) 561-562. - Type: India, Maharashtra, Concan, 1850, Stocks s.n. (K, holo; iso C).

Pothos cognatus Schott, Aroideae (1856-1857) 22, t.42 \& Prodr. Syst. Aroid. (1860) 562. - Pothos scandens L. var. cognatus (Schott) Engl. in A. \& C. DC., Monogr. Phan. 2 (1879) 84; Engl. in Engl., Pflanzenr. 21 (IV.23B) (1905) 26-27. - Type: India, Meghalaya, Khasia Hills, Hooker \& Thomson s.n. (K, holo).

Pothos zollingerianus Schott, Oesterr. Bot. Wochenbl. 5 (1855) 19; Miq., Flora Ned. Indië 3 (1856) 178. - Pothos zollingeri ('zollingerii') Schott, Aroideae (1856-1857) 21, t.32 \& Prodr. Syst. Aroid. (1860) 559-560; Engl. in A. \& C. DC, Monogr. Phan. 2 (1879) 85-86, orth. var. - Pothos scandens L. var. zollingerianus (Schott) Engl. in Engl, Pflanzenr. 21 
(IV. 23B) (1905) 26. - Type: Indonesia, Java, near Bandung, G. Ardjuno, 19 Sep 1844, Zollinger 2275 (L, holo; iso BM, P).

Pothos horsfieldii Miq., Fl. Ned. Indië 3 (1856) 178; Schott, Prodr. Syst. Aroid. (1860) 560-561. - Pothos angustifolius Reinw. ex Miq., Bot. Zeit. 14 (1856) 561, nom. illeg., non Pothos angustifolius C. Presl, Epimel. Bot. 243 (1849) (Myanmar). - Type: Indonesia, Java, Surokerto, 1802-1818, Horsfield s.n. (K, holo; iso A, BM).

Pothos decipiens Schott, Bonplandia 7 (1859) 165 \& Prodr. Syst. Aroid. (1860) 562-563. Type: India, W Bengal, probably near Calcutta, Voigt s.n. (C, holo).

Pothos fallax Schott, Prodr. Syst. Aroid. (1860) 559-560. — Type: Indonesia, S Kalimantan, Banjarmassin ('Bangarmassing'), 1857-1858, Motley 1194 (K, holo).

Pothos scandens L. fm. angustior Engl. Bot. Tidsskr. 24 (1902) 272. - Type: Thailand, Klong Munse, 7 Feb 1900, Schmidt 853 (C, lecto, selected by Boyce (2000: 181)).

Pothos scandens L. var. helferianus Engl. in Engl., Pflanzenr. 21 (IV.23B) (1905) 26. Type: Myanmar: Taninthari, Mergui, between Moulmine \& Martaban, Helfer sub Herb. East India Co. no. 5942 (K, lecto; isolecto P, selected by Boyce (2000: 181)).

[Pothos auriculatus S.Y. Hu, nom. nud. in sched. GH, MO].

[Pothos leschenaultii Buchet, nom. nud. in sched. P].

[Pothos nosibeensis Buchet, nom. nud. in sched. L, P].

[Pothos scandens L. var. falconeri Buchet, nom. nud. in sched. P].

[Pothos scandens L. var. godefroyi Buchet, nom. nud. in sched. P].

[Pothos scandens L. var. macrospadix Buchet, nom. nud. in sched. P]

Slender to moderately robust, homeophyllous, root-climbing liane. Shoot system welldifferentiated into adherent, non-flowering and free, often greatly elongated, lateral flowering branches; eocaul not observed; seedling with leaves congested, subshingling but not different in shape to those of adult shoots. Leaves bright to deepgreen adaxially, paler abaxially, drying dull green to brownish; petiole $2-14 \times 0.5-2 \mathrm{~cm}$, lamina-like, obovate-oblong to linear-oblong, base decurrent, apex truncate, rounded or auriculate; blade $2-10 \times 3-14 \mathrm{~cm}$, ovate to elliptic or lanceolate, base rounded to acute, apex attenuate-mucronate; primary lateral veins arising at $20-45^{\circ}$, intramarginal veins 2 per side. Inflorescence solitary in the axils of middle and distal leaves, borne on condensed shoots bearing a minute prophyll and a few 3-10 $\mathrm{mm}$ long (sequentially longer) cataphylls; peduncle 3-15 $\times 0.5-2 \mathrm{~mm}$, slender, erect to spreading, green to purple-tinged. Spathe 4-8 $\times 4-7 \mathrm{~mm}$, ovate, concave, margins variously inrolled, base short or somewhat long-clawed, apex rounded to acute with a tiny rather stout mucro, greenish to maroon. Spadix stipitate; stipe 5-10×c. $1 \mathrm{~mm}$, erect, the distal part erect to bent through $270^{\circ}$, greenish to maroon; fertile portion $4-10 \times 3.5-10 \mathrm{~mm}$, globose or ovoid to subclavate, yellow-green to off-white. Flowers c. 1-2 mm diam.; tepals 6, free; stamens 6 . Infructescence with 1-5 berries; fruit 10-17.5 × 10-14 mm, obclavate, midgreen ripening to deep scarlet; seeds c. 3-6 mm diam., ellipsoid to compressedglobose. - Figs. 1, 2.

Distribution - Widespread from Madagascar, through India and the Himalaya to SW China, south through Indochina. In Malesia: Peninsular Malaysia and Sumatera (in Sumatera only known from P. Simeulue), Borneo (Brunei and Sabah) and the Philippines.

Habitat - On trees and rocks in primary and secondary wet to dry lowland to hill evergreen tropical to subtropical forest, occasionally on sea cliffs, in hedges or scrub or 


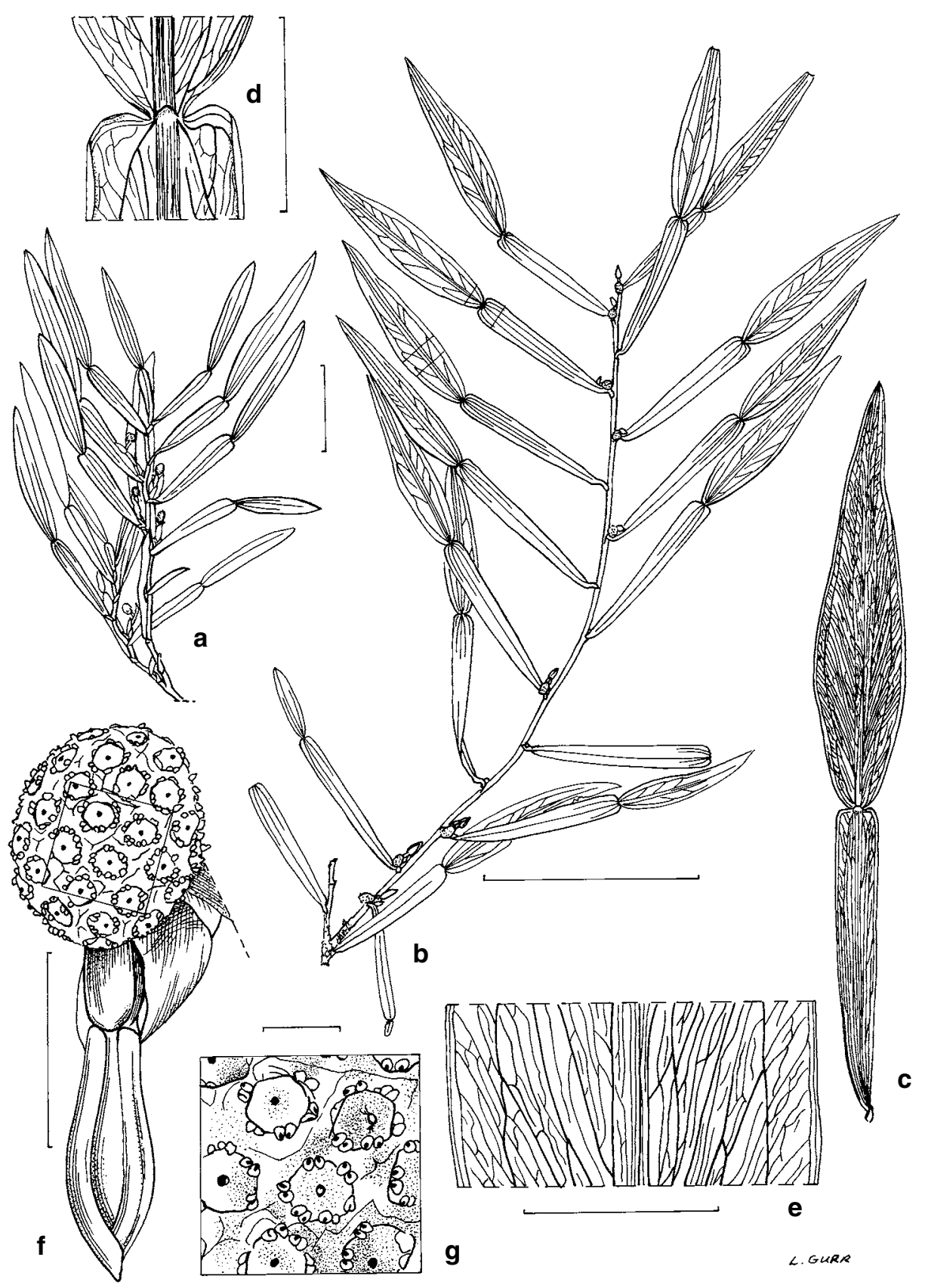

Fig. 1. Pothos scandens. $\mathbf{a}$, fertile shoot; $\mathbf{b}$, fertile shoot; $\mathbf{c}$, whole leaf; $\mathbf{d}$, detail of junction of lamina and petiole; e, venation detail; f, inflorescence; g, spadix detail: a, Helfer 5943; b-e, Collins 1730; $\mathrm{f}-\mathrm{e}$, Bogner 156. Scale bar: $\mathrm{a}=20 \mathrm{~mm} ; \mathrm{b}=100 \mathrm{~mm} ; \mathrm{c}=40 \mathrm{~mm} ; \mathrm{d}=10 \mathrm{~mm}$; $=10 \mathrm{~mm}$; $\mathrm{f}=5 \mathrm{~mm} ; \mathrm{g}=1 \mathrm{~mm}$. 


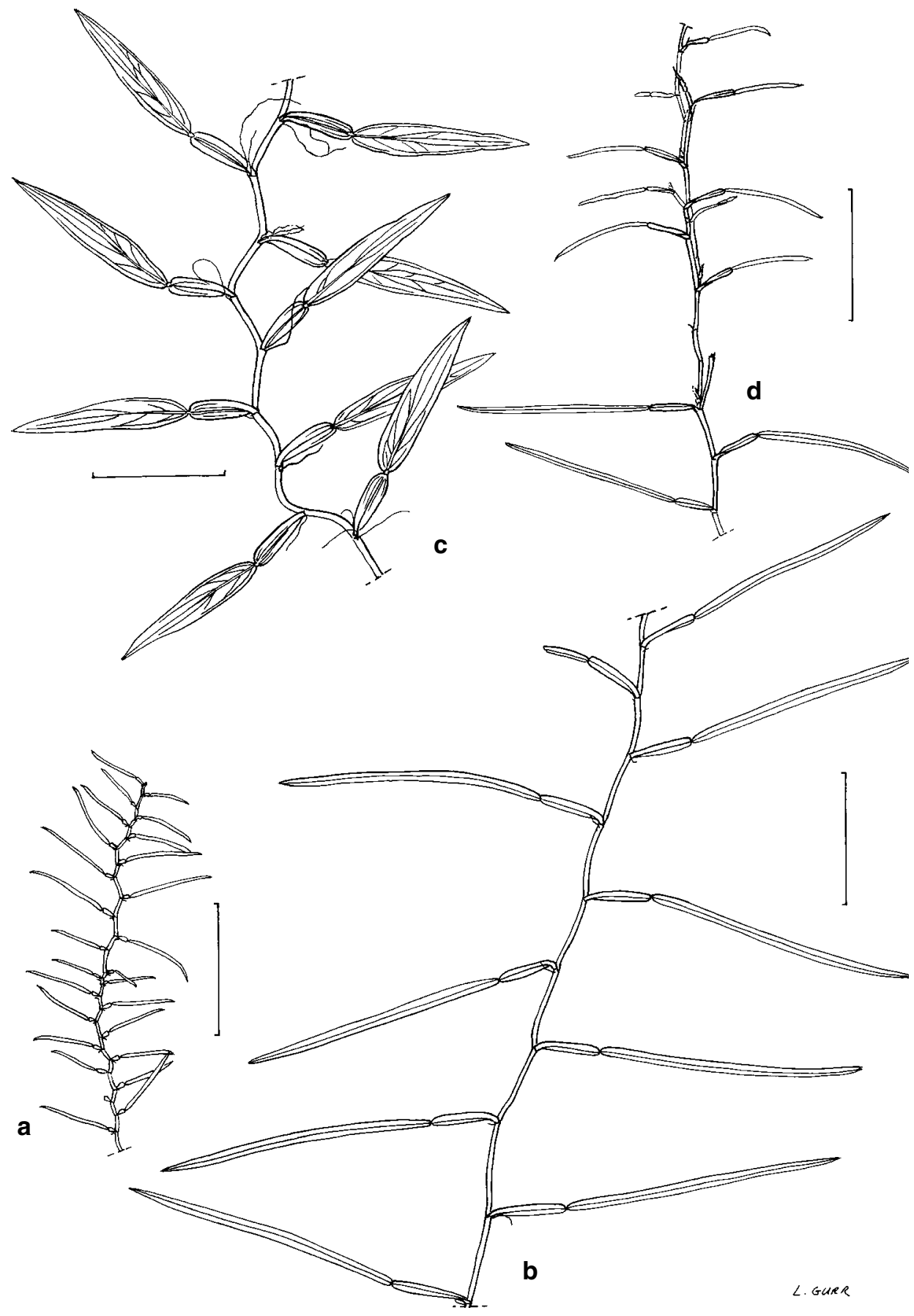

Fig. 2. Pothos scandens. $\mathbf{a}$, eocaul; $\mathbf{b}$, juvenile shoot; $\mathbf{c}$, juvenile shoot, later stage; $\mathbf{d}$, mature sterile shoot: a-d, Bogner 407 . Scale bar: $a=30 \mathrm{~mm} ; \mathrm{b}=30 \mathrm{~mm} ; \mathrm{c}=30 \mathrm{~mm} ; \mathrm{d}=30 \mathrm{~mm}$. 
in coconut plantations, on a variety of substrates including clay, limestone and granite. Sea-level to $1000 \mathrm{~m}$ altitude.

Notes - Pothos scandens has a wide geographical range and a bewildering range of morphological variation that has resulted in the recognition of many segregate taxa. Although most of these segregate taxa fit into $P$. scandens without stretching its morphological boundaries too much, P. angustifolius C. Presl, a much branched lowgrowing plant with extremely slender leaves and minute inflorescences, is exceptional. To date plants matching the type of $P$. angustifolius have only been collected along the Myanmar (Tenasserim) Andaman Sea coast, although similar but less congested plants have been found in Thailand. Further collections of this plant are required. Ideally, plants should be brought into cultivation to determine if the habit is retained or whether it is a plastic response to the plants' presumably harsh environment.

Pothos scandens is unmistakable in its typical aspect, carrying rather small inflorescences on bent peduncles. However, as noted above, the species is highly variable. Some populations comprise high-climbing plants bearing tiny inflorescences. Other populations produce rather large inflorescences not exhibiting the bent peduncle until very late anthesis or during early infructescence development. Such large-inflorescenced plants have been frequently incorrectly identified as ' $P$. roxburghii' (q.v.).

Pothos roxburghii de Vriese was based on a Wallich specimen and a Wight illustration, and also included a Junghuhn specimen from Sumatera. Schott excluded the latter and used it as the basis of his $P$. vrieseanus (= P. junghuhnii q.v.). Of the two remaining syntypes we have chosen the Wallich specimen over the illustration as lectotype of $P$. roxburghii as it is more useful for naming purposes.

The illegitimacy of Pothos longipedunculatus Engl. may be interpreted in two ways. First, Engler (1905) included P. roxburghii de Vriese in its synonymy, thus automatically making it a superfluous name for P. roxburghii. Second, however, it appears that he intended, in erecting $P$. longipedunculatus, to include only that part of $P$. roxburghii de Vriese represented by Junghuhn's specimen from Sumatera, since he had, three pages earlier, recognised $P$. roxburghii as an Indian species. By including the Junghuhn specimen as one of the two syntypes of P. longipedunculatus, he had included the type of $P$. vrieseanus Schott, thus rendering $P$. longipedunculatus a superfluous name for that species. Rather than fathoming Engler's intention (notwithstanding its being rather obvious), we have taken the first, more mechanical approach, and hence $P$. longipedunculatus goes into the synonymy of P. scandens rather than P. junghuhnii.

Other specimens examined: PENINSULAR MALAYSIA: Kedah, Ulu Muda, near Muda Daun valley, Bray FRI 11776 (A, K, KEP, SING); Pahang, 8 miles S of Kuala Lipis, Burkill \& Haniff SFN 17194 (SING, UCL); Perak, Ipoh, 2 miles N of Gopeng, G. Pipit, Chin 795 (SING, UPM); Johore, Sg. Kayu, Mawai to Jemaluang road, Corner SFN 32284 (SING); Terengganu, Kuala Brang, Corner SFN 33493, (BM, K, SING); Penang, Curtis 285 (SING); Selangor, Curtis 2394 (BM, SING); Penang, Haniff 2715 (SING); Perak, Kota Lawa, Kuala Kangsar, Haniff SAN 15560 (SING); Perak, Lubok Merbok to Kuala Kangsar, Haniff SFN 15994 (SING); Perak, Dinding to Telok Aman, Haniff SFN 14301 (SING, UCL); Selangor, Ulu Selangor, Sg. Buloh, Hardial \& Sidek 384 (A, C, K, SING); Perak, Tambau, near Ipoh, on way to Tanjung Rambutan, Hay et al. 9030 (NSW, UPM); Perlis, Mata Ayer, near Kangar, Henderson SFN 23084 (SING); Perak, Gua Badak, Lenggong, Henderson SFN 23844 (BO, K, SING); Terengganu, Kuala Terengganu, Pulau? Duyong Besar, Hume 89 (UPM); Pahang, Taman Negara, Bk. Mat Daling, Kasim 122 (UKMB); Kedah, Alor Setar, G. Keriang, Kiah SFN 35428 (K, SING); Pahang, Taman Negara, Kuala Sat, Latiff 104 (UKMB); Selangor, Highway from Kuala Lumpur to Fraser's Hill, Nicolson 1168 (US); Kedah, Langkawai, Bt. Sawak F.R., Nor FMS 31382 (KEP); Kedah, Kuala Kangsar, Ridley 2953 (BM, SING); Selangor, Bt. Gua, Ridley 8167 (BM, CAL, K, SING); Perak, Temengor, Ridley 14371 (BM, SING); Kedah, Alor Setar, Bk. Pinang, Ridley 14791 (BM, SING); Kedah, Alor Setar, Ridley s.n. (K); Selangor, Batu Caves, Ridley s.n. (BM, K); Selangor, Bt. Gua (Gowa), Ridley s.n. (SING); Perak, Scortechini 56 (K, SING); Perak, Scortechini 1137 (K); Perak, 
Scortechini s.n. (K); Johore, 19 miles along Kota Tinggi - Jemaluang road, Sinclair SFN 40354 (SING), Sinclair SFN 40356 (BM, E, K, P, SING, US); Kelantan, Gua Musang, Ulu Kelantan, UNESCO Limestone Exp. 317 (SING); Perak, Kg Kota, Wray 3322 (SING), Wray 3332 (BM, CAL, E); Kelantan, Bt. Lintang, G. Ring, Zainudin 1882 (UKMB). SUMATERA: P. Simeulue, Achmad 375 (SING), Achmad 1816 (K, P, SING). JAVA: W Java, Depok, Burck s.n. (BO); C Java, Kemantan, Tegal, Docters van Leeuwen s.n. (BO); C Java, Besuki Situ, Pancoer, Koorders 20433 (SING); E Java, Besuki (Besoeki) -Sirae Bando, Pandjaeri Tdjeri, Koorders 20433B (BO, P); E Java, Preanger, Besuki Jember, Koorders 20434 (A, BO); C Java, Pekalongan, Subah (Saebuh), Koorders 22539 (SING); Pasoeroean, TanghilZuidergeb, Koorders 23671B (P), C Java, Semarang, Kedungjack (Kedaengdjak), Koorders 25016 (SING); C Java, Subah (Soibah), Koorders $26401 B$ (BO, P); C Java, Preanger, G. Pangentjangan, Koorders 29883 (BO); Djapara, Tajoe Ngarengan, Koorders 35003B (P); Lahaie 2215 (P); No further information, Leschnault s.n. (P); Lörzing 1041 (BO); E Java, Madiun (Madioen), Wisse s.n. (BO); W Java, near Bandong, Zollinger 854Z (P). NUSA TENGGARA: P. Lombok, Elbert 1816 (BO, K); Sumbawa, Bima, Tuntu (Tente?), Elbert 3549 (A, B); W Sumbawa, Mt Bt. Lanteh, NW slope, trail from Bt. Dulang to Pusu, Kostermans 18699 (BO, K, SING, US); P. Bali, N of Tabanan, Mt Bt. Karu, road from Wongaja to Pura Luhur, Wirawan 444 (A, BO, K). BORNEO: SARAWAK: 5th Div., Lawas, Brooke 10030 (BM); 5th Div., Lawas River, Burbidge s.n. (K); No further information, 'Native collector' BS 1680 (US); Ist Div., Matang F.R., 10 miles W of Kuching, Nicolson 1283 (US); Ist Div., Kuching, Ridley s.n. (SING); 2nd Div., Rumah Danau, Ulu Engkilili, Yii S 44544 (K, L, SAR, US). BRUNEI DARUSSALAM: Muara, Gadong, Rimba, Wong 1635 (BRUN, K). SABAH: Lahad Datu, Bk. Blachan at Lahad Datu - Sandakan road ferry, Beaman 10129 (K, UKMS, US); Lahad Datu, Silam mainline, Chai SAN 26034 (K, SAN); Dallas, Tinimpok (Tenempok?) ridge, Clemens E Clemens 26808 (A, BM, K, SING, UCL); Ranau, Singgaron Baru, Marali side, Gambating SAN 114312 (K, KEP, SAN); Lahad Datu, Madai F.R., Sands 6033 (SAN); Ranau, near Kg Pinawantai, Shah \& Aban SAN 76765 (A, K, KEP, L, SAR, SING); Ranau, Kg Pinawantai, Shah \& Aban SAN 78765 (KEP, SAN). KALIMANTAN: 'Kapaeas', Teysmann 8100 (BO). PHILIPPINES: Luzon, Manila, Barthe s.n. (P); Luzon, Manila, Callery s.n. (P); Leyte, Mainit, Celis PNH 170403 (PNH); Mindoro, Mt Yagaw, S slope, Conklin PNH 18976 (A, PNH); Mindoro, N coast, Subaan River inland from San Teodoro, Coode 5378 (K, L, PNH); Mindanao, Davao, Copeland 959 (US); Mindoro, Mt Halcon, Edaño PNH 3382 (A, PNH); Luzon, Laguna, Los Banos, Elmer 9412 (E, K); Luzon, Laguna, Los Banos (Mt Maquiling), Elmer 18005 (A, C, BM, K, MO, P, US); Luzon, Zambales, Mt Pinatubo, Fox PNH 4722 (A, PNH); Luzon, Manila, Gaudichaud s.n. (P); Luzon, Laguna, Mt Maquiling, Gonzalez 1667 (K); Luzon, Laguna, Mt Maquiling, Sitio Kalbano, above Forestry College, Lagrimas PNH 9715 (A); Luzon, Rizal, Loher 7044 (K); Luzon, Rizal, Loher 7045 (K); Luzon, Rizal, Loher BS 14778 (A); Luzon, Laguna, Mabesa BF 24911 (P); Luzon, Laguna, Mt Macquiling, Merrill Sp. Blanco. 57 (A, BM, K, MO, P, US); Luzon, Rizal, Bozobozo, Merrill BA 2792 (BM, K, P, US); Luzon, Laguna, path along Molawin Creek between Colleges of Agriculture and Forestry, Nicolson 748 (US); Luzon, Laguna, Mt Maquiling, path near Mud Springs, Nicolson 840 (US); Luzon, Rizal, Ramos BS 4 (US); Luzon, Rizal, Ramos BS 13622 (BM, MO, US); Samar, Catubig River, Ramos BS 24475 (BM, K, P, US); Luzon, Rizal, Reillo BS 19211 (BM, K, P, US); Luzon, Laguna, Mt Maquiling, Sulit PNH 7071 (A, PNH); Luzon, Albay, Saraga, Vidal 1950 (K); Luzon, Batangas, NE Maquiling, Vidal 1989 (A, K); Luzon, Bataan, Morow, Vidal 1990 (A, K); Luzon, Camarines Sur, NE Isarog, Vidal 3966 (A, K); Leyte, Wenzel 265 (MO); Luzon, near Banos Luconia, Wilkes s.n. (A). SULAWESI: Sulawesi Utara, $250 \mathrm{~km} \mathrm{~W}$ of Gorontalo, $75 \mathrm{~km}$ inland from Papayuto, tributary of Sg. Papayuto, Burley et al. 4159 (BO, K). MALUKU: Sula Mangoli, $\mathrm{N}$ of Kg Mangoli, Bloembergen 4570 (A, SING), P. Ceram, Manusela N.P., Wae Mual, Edwards 228 (E); P. Mangole, G. Papao, Hulstyn 23 (BO); W Ceram, Kairatu, Gemba, Kuswata \& Soepadmo 28 (A, BO, K, SING); Ambon, Lahaie 1061 (P); P. Ambon, Robinson Pl. Rumph. Amboin. 118 (A, BM, K, MO, P, SING, US); P. Ceram, Suharno 229 (BO); Ambon, Hila, Treub s.n. (BO).

2. Pothos clavatus Engl.

Pothos clavatus Engl. Bull. Soc. Tosc. Ortic. 4 (1879) 266 \& in Becc., Malesia 1 (1883) 261, t.16, figs 1-4 \& in Engl., Pflanzenr. 21 (IV.23B) (1905) 31-32; Hay, Blumea 40 (1995) 413. - Type: Papua Barat, Kepala Burung Prov., Sorong, 1872, Beccari p.p. 487 (B, lecto; isolecto FI, selected by Hay (1995: 413)).

Slender root-climbing liane or hemi-epiphyte. Shoot system well differentiated into adherent, non-flowering and free, lateral flowering branches; ecocaul and seedling not observed. Leaf dark green, rather fleshy; petiole $3-5 \mathrm{~cm} \times 1.1-1.5 \mathrm{~cm}$, lamina-like, 


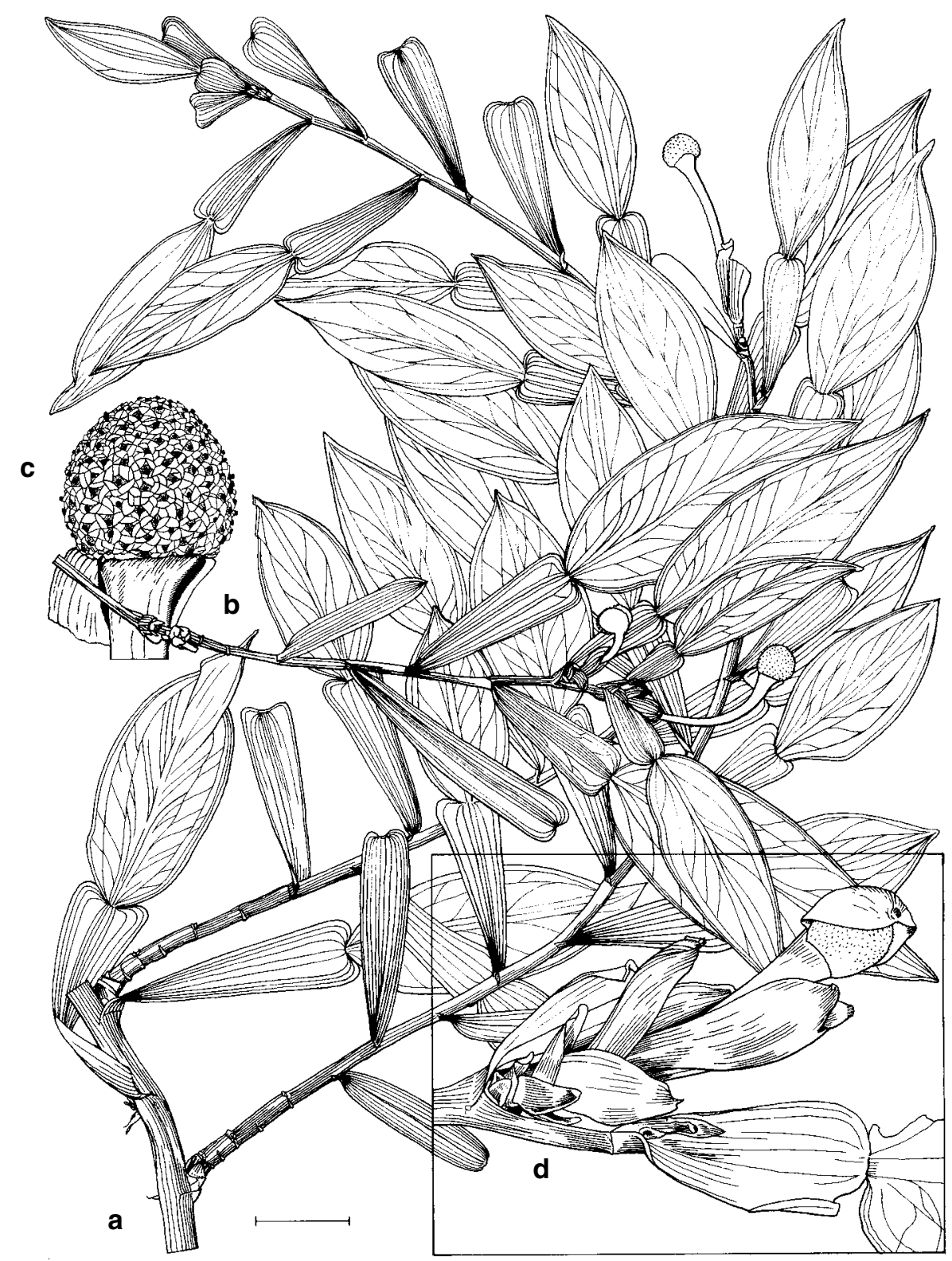

Fig. 3. Pothos clavatus. a, fertile shoot; b, fertile shoot; c, spadix; d, fertile shoot: a, Pleyte 723; b \& c, Streimann NGF 28802; d, Carr 12116. Scale bar: a, c $=2 \mathrm{~cm} ; \mathrm{b}=8 \mathrm{~mm} ; \mathrm{d}=7 \mathrm{~mm}$. 
shorter than the blade, distally emarginate to auriculate; blade c. $6.5-10 \mathrm{~cm} \times 2-4.5 \mathrm{~cm}$, narrowly ovate to ovate to oblong-obovate, apex acute to somewhat acuminate, base rounded; primary lateral nerves diverging at 40-60', intramarginal veins 2 or 3 on each side of the midrib. Inflorescence solitary, in the axils of distal leaves, borne on condensed short shoots and subtended by cataphylls, the last and largest oblong, c. $2 \mathrm{~cm}$ $\times 1 \mathrm{~cm}$; peduncle $1-4.5 \mathrm{~cm}$ long, very abruptly expanded at junction with spadix and there c. $1 \mathrm{~cm}$ diam., blackish purple. Spathe c. $1.2 \times 1 \mathrm{~cm}$, broadly ovate, reflexed, greenish to purple-tinged. Spadix sessile; fertile portion c. $1.4 \mathrm{~cm}$ diam., \pm spherical, yellow. Flowers c. $1.2 \mathrm{~mm}$ diam., with 6 free tepals and 6 stamens. Infructescence with rather few berries; fruit c. $1.1 \mathrm{~cm}$ long, ovoid, ripening red; seeds not observed. - Fig. 3.

Distribution - Malesia: endemic to New Guinea (confined to western Papua Barat).

Habitat - Lowland primary and secondary rainforest and fresh-water swampforest, 70-400 $\mathrm{m}$ altitude.

Note - Distinguished by the tip of the stipe abruptly expanded at the insertion of the fertile portion of the spadix, giving the latter the appearance of being borne in a cupule.

This species and $P$. hellwigii are evidently very closely related. The great majority of collections can be ascribed to one or other of these with confidence. However, there are occasional collections [of which Nicolson 1415, Papua New Guinea, Central Prov., Brown River F.R. (K, US) is typical] which appear to fall somewhere between $P$. clavatus and $P$. hellwigii. Interestingly, the Nicolson collection comprises a sheet with young inflorescences $(K)$ that matches $P$. clavatus very well by the peduncle shape, and a fruiting specimen (US) which much more closely approaches $P$. hellwigii. Whether these intermediate specimens indicate incomplete separation of these species is not yet clear.

Pothos clavatus is confined to western New Guinea, while P. hellwigii is wide-ranging in New Guinea and Solomon Islands.

Other specimens examined: NEW GUINEA: PAPUA BARAT: Kepala Burung Prov., Ramoi, Beccari p.p. 329 (FI); Kepala Burung Prov., Sorong, near Remu, Pleyte 723 (L, SING); Kepala Burung Prov., Rufei River, N of Sorong, van Royen 3153 (L); Waigei Is., Radjah Ampat, van Royen 5252 (L). PAPUA NEW GUINEA: Central Prov., Port Moresby, Koitaki (c. 30 km WNW of Port Moresby), Carr 12116 (BM, K, L, SING); Milne Bay Prov., Raba Raba, Biniguni to Maneau track, Streimann NGF 28802 (A, BRI, K, L, LAE, SING, US).

\section{Pothos gracillimus Engl. \& K. Krause}

Pothos gracillimus Engl. \& K. Krause, Bot. Jahrb. Syst. 54 (1917) 74, fig.1; Hay, Blumea 40 (1995) 417. - Type: Papua New Guinea, ('Kaiser Wilhelms Land'), Telefomin Prov., Mai (Yuwa) River, Pfingstberg, 25 May 1912, Ledermann 7411 (B, holo; iso E, K, SING).

Very slender, diminutive root-climbing liane or hemi-epiphyte. Shoot system very weakly differentiated into non-flowering and flowering branches; eocaul and seedling not observed. Leaf pale green, sub-chartaceous; petiole c. $1.5-3 \mathrm{~cm} \times 3-4 \mathrm{~mm}$, laminalike, c. $1 / 4-1 / 3$ the length of the blade, distally rounded to somewhat auriculate; blade c. 5-9 cm $\times$ c. 3-7 mm, very narrowly lanceolate, apex attenuate, base rounded; primary lateral veins diverging at c. $20^{\circ}$, intramarginal veins 1 or 2 on each side of the midrib. Inflorescence solitary on condensed short shoots in the axils of distal leaves, subtended by cataphylls, the last and longest very narrowly lanceolate, c. $1-1.5 \mathrm{~cm}$ long; peduncle to c. $3.5 \mathrm{~cm}$ long, very slender. Spathe 6-8 $\times 4-5 \mathrm{~mm}$, ovate-lanceolate, green. Spadix sessile, c. 3-7 × 3-4 mm, subspherical to ovoid-cylindric, green. Flowers c. $1.2 \mathrm{~mm}$ diam., with 6 free tepals and 6 stamens. Infructescence with $1-\mathrm{few}$ berries; fruit ovoid to elliptic-obovoid, c. $1 \mathrm{~cm}$ long, cherry red when ripe; seeds not observed. - Fig. 4. 


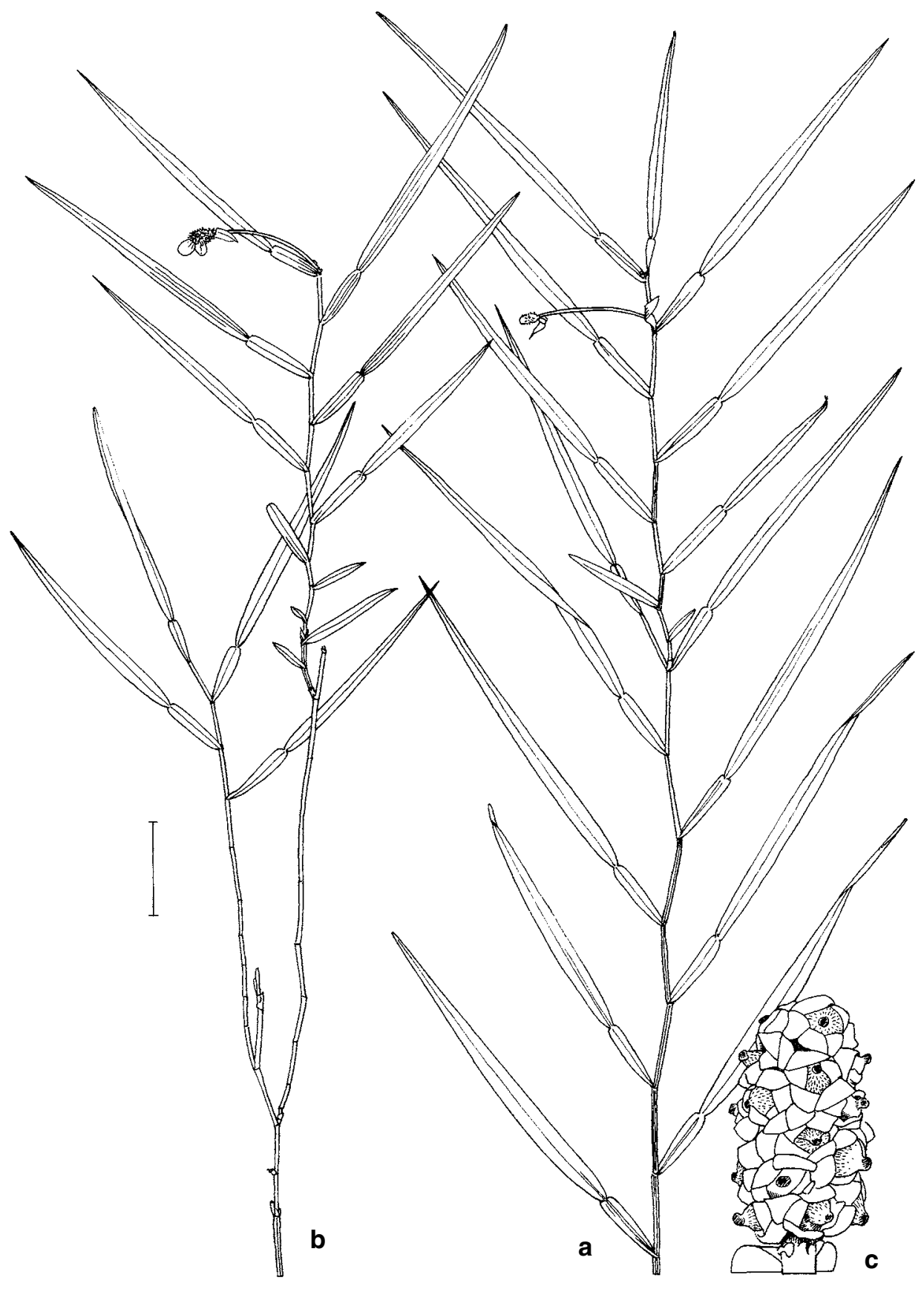

Fig. 4. Pothos gracillimus. a, fertile shoot in flower; $\mathbf{b}$, fertile shoot in fruit; $\mathbf{c}$, spadix detail: $\mathbf{a}-\mathbf{c}$, Ledermann 7411. Scale bar: $\mathrm{a}, \mathrm{b}=2 \mathrm{~cm} ; \mathrm{c}=2 \mathrm{~mm}$. 
Distribution - Malesia: endemic to New Guinea; known from only two very widely separated sites.

Habitat - Lowland to hill forest, up to $400 \mathrm{~m}$ altitude.

Note - This species is closely related to P. zippelii, differing principally in its very diminutive and slender stature. The very scattered distribution may indicate that this is a rare and/or very easily overlooked plant. Alternatively, the distribution may simply suggest that this is a sporadically arising depauperate form of P. zippelii; however, there are as yet no linking intermediates.

Other specimen examined: NEW GUINEA: PAPUA NEW GUINEA: Gulf Prov., Vailala River, Wade s.n. (K).

\section{Pothos hellwigii Engl.}

Pothos hellwigii Engl. Bot. Jahrb. Syst. 25 (1898) 2; K. Schum. \& Lauterb., Fl. Schutzgeb. Südsee (1901) 210; Engl. in Engl., Pflanzenr. 21 (IV.23B) (1905) 31, fig.13; Rech., Denkschr. Wien Akad. Wiss. (1913) 509; Peekel ex Henty, Fl. Bismarck Archipelago (1984) 66, fig.109; Hay, Blumea 40 (1995) 411-412. - Type: Papua New Guinea, Morobe Prov., Finschhafen, Butaueng, 20 Mar 1889, Hellwig 468 (B, lecto, selected by Hay (1995: 411)).

Pothos hellwigii Engl. var. latifolius Lauterb., Bot. Jahrb. Syst. 45 (1911) 358. - Type: Papua New Guinea, New Ireland, Nebumai, Peekel 239 (holo B †). No extant material of this collection is known to exist. Furthermore, no other collections of $P$. hellwigii from New Ireland have been traced and thus neotypification is not undertaken here.

[Pothos clavatus auct. non Engl. apud Ridl., Trans. Linn. Soc. Lond. 9 (1916) 240].

Slender to moderately robust, often very vigorous root-climbing liane or hemiepiphyte. Shoot system well-differentiated into pendulous, free, lateral flowering branches and adherent shoots; eocaul not observed; seedling with congested leaves closely resembling adult leaves but smaller, becoming progressively larger as shoots elongate. Leaf dark green above, paler below; petiole $1-8 \mathrm{~cm}$, weakly lamina-like, usually considerably shorter than the blade, $1 / 7$ to $2 / 3$ its length, the distal part somewhat to distinctly auriculate, sub-triangular (when short) to subparallel-sided (when longer); blade c. 8-12 $\times 2-4 \mathrm{~cm}$, ovate-lanceolate to ovate (usually absent from early leaves of a sympodial module), apex not or somewhat acuminate, base mostly rounded; primary lateral veins diverging at $40-85^{\circ}$, intramarginal veins mostly 2 on each side of the midrib, one basal and running to the margin, one from about midway up the blade, running to the tip. Inflorescence solitary, rarely paired, borne on leafless condensed short shoots (these rarely with 1 or 2 reduced blade-bearing leaves) in the axils of usually only the most distal leaves, or less commonly terminal on the leafy shoot, or rarely on older leafless parts of the stem, the short shoots sometimes with scars of previous flowering, subtended by series of cataphylls, the longest and last to c. $3 \mathrm{~cm}$ long; peduncle to c. $7 \mathrm{~cm}$ long, gradually thickening upwards from from the base more or less evenly throughout its length, slightly curved, deep purple-black. Spathe c. $1 \times 2 \mathrm{~cm}$, broadly ovate, emarginate-tipped, mucronulate, reflexed, dark green to dark purple. Spadix sessile, 0.6-1.3 (-1.8) cm diam., spherical, yellow. Flowers c. $1.1 \mathrm{~mm}$ diam. (dry), with 6 free tepals and 6 stamens. Infructescence with few to many berries; fruit to $2.5 \mathrm{~cm}$ long (fresh), ovoid, ripening deep red; seeds not observed. - Fig. 5.

Distribution - Solomon Islands (few records). In Malesia: widespread and common in New Guinea, with fewer records in the Bismarck Archipelago.

Habitat - Lowland rainforest, secondary regrowth and lower montane rainforest, sea level to $1000 \mathrm{~m}$ altitude. 


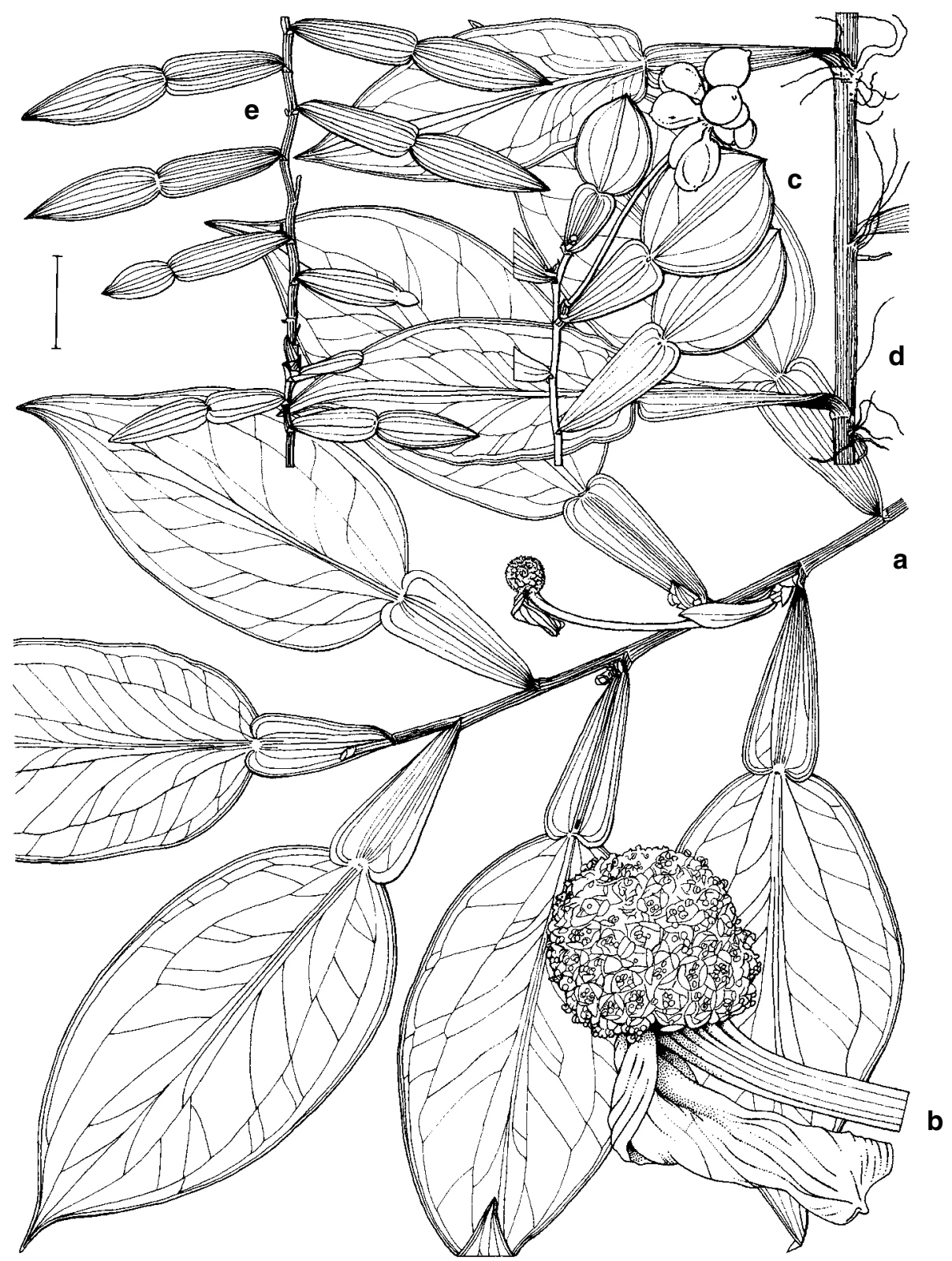

Fig. 5. Pothos hellwigii. $\mathbf{a}$, fertile shoot; $\mathbf{b}$, inflorescence; $\mathbf{c}$, infructescence; $\mathbf{d}$, adult adherent shoot; e, juvenile adherent shoot: $\mathrm{a}-\mathrm{c}$, Johns 7657; $\mathrm{d}-\mathrm{e}$, Nicolson 1481. Scale bar: $\mathrm{a}=3 \mathrm{~cm} ; \mathrm{b}=4 \mathrm{~mm}$; $\mathrm{c}-\mathrm{e}=2 \mathrm{~cm}$. 
Notes - Closely related to $P$. clavatus, but typically differing in the peduncle not abruptly swollen at the insertion of the spadix. However, intermediates between the two species do occur (see under P. clavatus).

Pothos hellwigii is also close to $P$. zippelii, although typically differs in the globose, not ellipsoid, fertile spadix. Here too, however, there are collections in which the fertile spadix is intermediate in shape between that of $P$. hellwigii and that of $P$. zippelii [notably Nicolson 1576: Papua Barat, Kepala Burung Prov., 2 km N of Manokwari (A, B, BM, BRI, K, L, LAE, P, SING, US) and Brass 13876: Papua Barat, Jayapura Prov., Taritatau ('Idenburgh') River, Bernhard Camp (A, BRI, L)].

Other specimens examined: NEW GUINEA: PAPUA BARAT: Mimika Prov., Puncak Jaya (Mt Carstensz), Camp VI a, Boden Kloss s.n. (BM, K); Kepala Burung Prov., Meremi, Manokwari, BW 9806 (BRI, L, LAE); Kepala Burung, Manokwari, Kebar, Kebar valley, trail from Andjai to G. Neotti, near Base Camp N, Davis 744 (BO, K, MAN); Jayapura Prov., Bonggo Range, nr Albatross Bivak, Docters van Leeuwen 9129 (BO); Kepala Burung Prov., along side of road from Manokwari to G. Meja, Johns 7657 (BO, K, MAN); Mimika Prov., Freeport Concession Area, Ecological Plot 5 near Kuala Kencena, Johns 8764 (BO, K, MAN); Mimika Prov., Freeport Concession Area, surrounding Golf Course, Johns 9855 (BO, K, MAN); Mimika Prov., Freeport Concession Area, Golf Club grounds, Johns 10489 (BO, K, MAN); W end of Tafelberg F.P., 2 km N of Manokwari, Nicolson 1579 (B, K, L, P, US); Mimika Prov., Freeport Concession Area, Rimba Irian Golf Course, outskirts of Kuala Kencena, Puradyatmika 10441 (BO, K, MAN); Mimika Prov., Freeport Concession Area, in front of Golf Club towards access road, Utteridge 309 (BO, K, MAN); Kepala Burung Prov., Tubub, N side of Lake Ajamaru, Vink BW 15355 (A, K, L, LAE); Kepala Burung Prov., Segior, NW side of Lake Ajamaru, Vink \& Vink BW 15295 (K, L); Mimika Prov., Fakfak, Widjaja 2511 (BO). PAPUA NEW GUINEA: Milne Bay Prov., Normanby Is., Vaikaiuna, Brass 25609 (L); Morobe Prov., Oomsis Creek, Brass 29186 (K, US); Western Prov., lower Fly River, E bank opposite Sturt Is., Brass 8242 (BRI, L); Central Prov., Kanosia, Carr 11565 (BM, K, L, SING); Central Prov., Kanosia, Carr 11566 (BM, K, SING); Morobe Prov., Boana, Clemens 41333 (US); Morobe Prov., Lae, Busu logging area, Coode et al. NGF 32724 (A, BO, BRI, CANB, E, K, L, LAE, NSW, SING, US); Morobe Prov., Wau to Lae road, Purinin River, Floyd NGF 6969 (K, LAE); Morobe Prov., Oomsis Creek, Floyd NGF 7289 (K, LAE); Milne Bay Prov., Alotau, Magi Highway, 5 km from junction to Watubo, Gideon LAE 77065 (L, LAE, US); Morobe Prov., near Butibum River, c. 6 miles N of Lae, Hartley 11897 (BRI, CANB, K, L, LAE); Morobe Prov., c. 18 miles W of Lae, Oomsis Creek, Hartley 10479 (BRI, CANB, K, L); Morobe Prov., Markham valley, Oomsis creek, near Lae, Henty NGF 10663 (K, LAE); New Britain, Kandrian, Pulie River, W side, Henty NGF 41828 (A, CANB, K, L, LAE, US); New Britain, Kandrian, Pulie River, W side, Henty \& Frodin NGF 27249 (A, BO, BRI, CANB, K, L, LAE); Morobe Prov., SE of Lae, on coast, opposite Lasanga Is., Jacobs 9577 (L, US); Morobe Prov., Lae, Oomsis creek, Johns NGF 47435 (BRI, CANB, K, L, LAE); Central Prov., Brown River F.R., Edevu logging area, 20-25 miles NW of Port Moresby, Kairo NGF 30841 (A, BO, BRI, CANB, K, L, LAE, NSW, SING); Central Prov., Brown River F.R., 20-25 miles NW of Port Moresby, Laravita \& Vinas LAE 62235 (A, BRI, CANB, E, K, L, LAE, US); Bougainville, Pavairi, Lavarack \& Ridsdale NGF 31092 (A, BO, BRI, CANB, K, L, LAE, US); Eastern Prov., Fife Bay, Lister Turner 22 (BM); Morobe Prov., Oomsis logging camp, near Lae, Millar NGF 11798 (LAE, K, SING); Morobe Prov., Oomsis Creek, near Lae, Millar NGF 9919 (LAE, K); Bougainville, Taki, Toiumompu plantation, NGF 16403, (BRI, L, LAE); Morobe Prov., Bumbu logging area, 7 miles N of Lae, Nicolson 1387 (K, L, US); Morobe Prov., Bumbu logging area 7 miles $\mathrm{N}$ of Lae, Nicolson 1388 (K, L, US); Morobe Prov., Bumbu logging area, 7 miles N of Lae, Nicolson 1389 (K, L, US); Morobe Prov., Oomsis Creek, 20 miles from Lae on the Bulolo road, Nicolson 1481 (B, K, L, P, US), Nicolson 1482 (B, K, L, P, US); Bougainville, Arawa, McKillup's plantation 6 miles E of Kieta, Nicolson 1519, (B, K, US); New Britain, Kandrian, along road to airport, Nicolson 1538 (B, K, L, LAE, P, US); Central Prov., Abau, Mori River, Sayers NGF 19641 (A, BO, BRI, CANB, K, L, LAE, NSW, SING, US); Morobe Prov., Lae, Gabensis to Wagau track, 6 miles $S$ of Gabensis, Streimann \& Fasavalu, NGF 47741 (A, BO, BRI, CANB, K, L, LAE, NSW, SING, US); Bougainville, Siwai, Waterhouse 196-B (K), Waterhouse 196-B-B (BRI, C, K, LAE, NSW); Morobe Prov., Busu River area, c. 10 miles N of Lae, Webster $\mathcal{E}$ Hildreth 15087 (MO, UCL); Morobe Prov., Lae, Bupu River, 12 miles E of Lae, Womersley NGF 43681 (A, BRI, CANB, K, L, LAE, US). SOLOMON ISLANDS: Choiseul, N Choiseul, along and W of Wasile River, Gafui et al. BSIP 17385 (BSIP, K, L, LAE, SING). 
5. Pothos junghuhnii de Vriese in Miq., Pl. Jungh. (1851) 104; Miq., Flora Ned. Indië 3 (1856) 179-180. - P. junghuhnianus Schott, Aroideae (1856-1857) 23, t.49 \& Prodr. Syst. Aroid. (1860) 567, orth. var. - Type: Indonesia, Sumatera Utara, Tobing, Junghuhn s.n. (L, holo).

Pothos scandens L. var. javanicus de Vriese, Pl. Jungh. 1 (1851) 103 ('javanica'), syn. nov. -Type: Indonesia, Java, 18 Aug 1842, Zollinger 422 (L, holo; iso BM, K, P).

Pothos macrophyllus de Vriese in Miq., Pl. Jungh. 1 (1851) 104 ('macrophylla'); Schott, Aroideae (1856-1857) 23, t.38 \& Prodr. Syst. Aroid. (1860) 566-567; Engl. in A. \& C. DC, Monogr. Phan. 2 (1879) 82 \& in Engl., Pflanzenr. 21 (IV.23B) (1905) 30-31, nom. illeg. non Sw. (1788), syn. nov. - Type: Indonesia, Sumatera Utara, Junghuhn s.n. (L, holo).

Pothos vrieseanus Schott, Aroideae (1856) 22, t.36 \& Prodr. Syst. Aroid. (1860) 565; Engl. in A. \& C. DC., Monogr. Phan. 2 (1879) 80-81 \& Engl. in Engl., Pflanzenr. 21 (IV.23B) (1905) 24, syn. nov. - Type. Indonesia, Sumatera, Junghuhn s.n. (L, holo).

Slender to moderately robust, homeophyllous, root-climbing liane. Shoot system welldifferentiated into adherent, non-flowering and free, lateral flowering branches; eocaul and seedling not observed. Leaves bright to mid-green adaxially, paler abaxially, drying dull green; petiole $3.5-8 \times 0.5-2 \mathrm{~cm}$, broadly winged, oblong to obovate-oblong, base decurrent to clawed, apex truncate, rounded or weakly auriculate; blade 3-13 $\times 1.5-6 \mathrm{~cm}$, ovate to elliptic or oblong-lanceolate, base rounded to acute, apex attenuate-mucronate to acute or attenuate, briefly tubulate; primary lateral veins arising at $45-65^{\circ}$, intramarginal veins 2 per side of the midrib, these arising from the base and remaining rather close to midrib before diverging further along blade. Inflorescence solitary, arising from the distal leaf axils of fertile shoots, subtended by a minute prophyll and a few $0.5-3.5 \mathrm{~cm}$, sequentially longer cataphylls; peduncle slender, 2.5-4(-5) cm $\times 1-1.2 \mathrm{~mm}$, erect, dark purple. Spathe 6-15(-20) $\times 4-10(-15) \mathrm{mm}$, ovate, flat to convex, base cordate, clasping the peduncle, apex slightly raised, acute to subacute with a small mucro, dull green to purple. Spadix stipitate; stipe slender, (1-)2.5-3.5 × 1-1.5 mm, erect, straight, dark purple; fertile portion (3-) 6-14(-20) $\times$ (3-)3.5-6(-10) $\mathrm{mm}$, globose to ovate-ellipsoid or ovoid-clavate, cream to yellow. Flowers $0.6-1.2 \mathrm{~mm}$ diam., with 6 free tepals and 6 stamens. Infructescence with 1-8 berries; fruit c. 4-7 mm diam, ovoid or ellipsoid, ripening scarlet; seeds c. 3-6 mm diam., ellipsoid. - Fig. 6.

Distribution - Malesia: Sumatera, Java; one record from Sarawak but with no further information available.

Habitat - Primary to disturbed secondary forest, often on limestone, 5-600 m altitude.

Notes - Pothos junghuhnii displays a wide range of robustness, in particular in the size of the inflorescences which can vary greatly, even on different branches of the same individual. These variations have been the basis for the species regarded here as synonyms, with the smaller forms equating to $P$. vrieseanus and the larger forms to $P$. macrophyllus / P. junghuhnii. Generally, but not exclusively, Sumateran plants tend to be more robust with larger inflorescences.

In Sumatera confusion with P. macrocephalus is possible, although P. junghuhnii has the petiole not exceeding the blade and tends to be less floriferous. Fresh flowering material is separable on inflorescence colour - the peduncle and stipe purple and the spathe tending to green or purple in P. junghuhnii (peduncle orange-yellow, the stipe pale green and the spathe white in $P$. macrocephalus).

Other specimens examined: SUMATERA: W Sumatera, Kepulauan Mentawi, P. Sipora, Batten Pool s.n. (SING); Bengkulu, Kepahaing, de Voogt 1303 (BO); Sumatera Barat, near K. Longsat, c. 20 km W from Sg. Dareh, Hotta et al. 96 (BO, KYO, SING); Padang Si Dimpoean, Padang Lawas, Sopsopan 


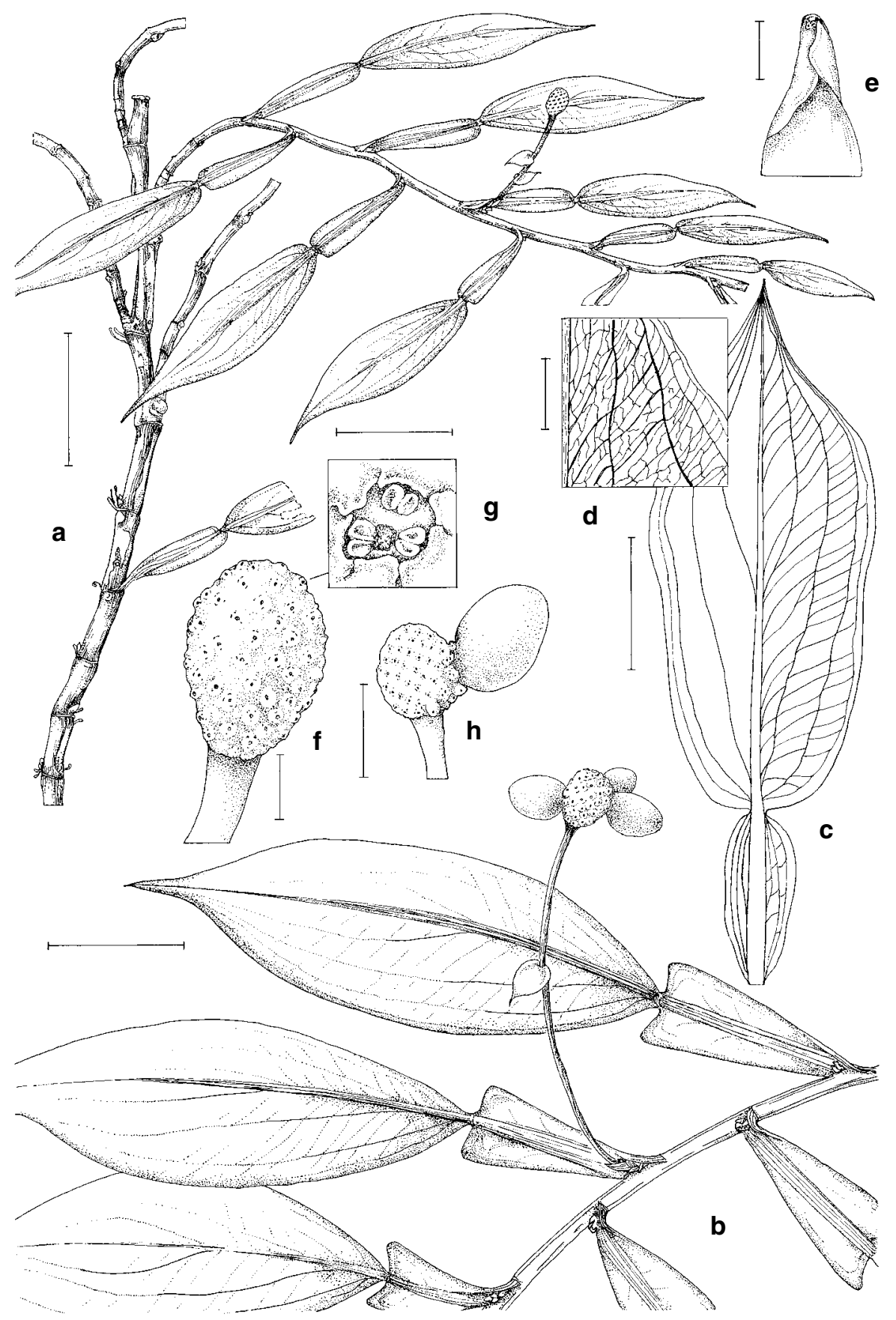

Fig. 6. Pothos junghuhnii. $\mathbf{a}$, adherent sterile and free lateral fertile shoot; $\mathbf{b}$, fertile shoot; $\mathbf{c}$, whole leaf; $\mathbf{d}$, venation detail; e, lamina tip; $\mathbf{f}$, spadix; $\mathbf{g}$, detail of single flower; $\mathbf{h}$, infructescence: $\mathrm{a}, \mathrm{c}-\mathrm{g}$, Bakhuizen van den Brink 4910; b, h, Hotta et al. 96. Scale bars: $a=3 \mathrm{~cm} ; \mathrm{b}, \mathrm{c}=2 \mathrm{~cm}$; d $=5 \mathrm{~mm}$; $\mathrm{e}=1 \mathrm{~mm} ; \mathrm{f}=3 \mathrm{~mm} ; \mathrm{g}=1 \mathrm{~mm} ; \mathrm{h}=1 \mathrm{~cm}$. 
on Aek Si Olip, Rahmat Si Toroes 5439 (A); E Coast, Ridley s.n. (BM); E Coast, Asahan, above Bandar Puluh, Yates 1333 (B, UCL), Yates 1764 (BO, UCL). JAVA: W Java, Bandjar, Bandar Dawa, Backer s.n. (BO); W Java, Bantam, between G. Kentjana and G. Kendang, Backer 1276 (BO, K); W Java, Bantam, Pandegelang, Backer 7457 (BO); W Java, Bantam, Pandegelang, Backer 7499 (BO); W Java, W Preanger, Badjong Lopang to Lengdong, Backer 17013 (BO); W Java, Klappa Nuygal(?), NE of Bogor, Backer, 23376 (BO); W Java, Laladan, Ciomas ('Tjiomas'), Bakhuizen van den Brink 4057 (BO); W Java, Jakarta, Cikandang ('Tjikandang'), G. Parang, Bakhuizen van den Brink 4910 (BO, K, P, SING); W Java, Preanger, Batang Gadung ('Gadoeng'), Beumée 534 (BO); W Java, Bantam, Preanger, Pungilis, between Bandjar and Kalipuchang ('Kaliputjang'), Beumée 722 (BO); W Java, Cibaruk? ('Tjideroek'), Boerlage s.n. (BO, K); W Java, Bantam, Bantandjaja, Sindangwangi, c. $24 \mathrm{~km} \mathrm{~S}$ of Rangkasbetong, Buwalda 2907 (BO); W Java, Bogor, Didrichsen s.n. (C); no further information, Forbes 407 (BM); Yogyakarta, Kaliboto, Hallier s.n. (BO); C Java, Purwokerto, G. Binangun, Joss 101 (BO); W Java, Bogor, Junghuhn s.n. (BM); W Java, Bogor, Kaap 87 (BO); W Java, Bogor, Kollmann s.n. (BM); C Java, Nusa Kambangan, Koorders 22061 (BO); C Java, Nusa Kambangan, Koorders 22067 (BO); C Java, Nusa Kambangan, Koorders 24129 (BO, K); W Java, Jakarta, Depok, Koorders 31167 (BO); W Java, Jakarta, Depok, Koorders 44108 (BO); W Java, isthmus of Udjung Kulon, Kostermans 19339 (A, BO, C, K, L); W Java, Mt Hondje, Kostermans 19349 (A, BO, C, L, US); W Java, Situ Pandjalu, Tjiamis, Tasikmalaya ('Tasikmalaja'), Kostermans et al. 375 (BO, K); no further information, Lobb s.n. (K); no further information, Nagle s.n. (K, P); W Java, G. Moenara, Roempin Estate, NW of Bogor, Saimoendt 11 (BO); W Java, Jakarta, van Harreveld 684 (BO); W Java, Ciribon ('Cheribon'), Lingajati ('Linggadjati'), van Steenis 12509a (A, BO, K, SING); W Java, Priangan, Sangkiangtoro, G. Guntur ('Goentoer'), van der Pijl 100 (BO). BORNEO: SARAWAK: no further information, Brooks s.n. (BM).

\section{Pothos macrocephalus Scort. ex Hook.f.}

Pothos macrocephalus Scort. ex Hook.f., Fl. Brit. Ind. 6 (1893) 553; Engl. in Engl., Pflanzenr. 21 (IV.23B) (1905) 31; Ridl., Mat. Fl. Malay Penins. 3 (1907) 49 \& Fl. Malay Penins. 5 (1925) 128, fig. 217; Henderson, Malayan Wild Flowers, Monocots (1954) 238-239, fig.143B,C; Boyce, Blumea 45 (2000) 172-175, fig. 6a \& b. - Type: Malaysia, Perak, Larut, Scortechini 116b (CAL, lecto; isolecto K, US; selected by Boyce (2000: 172)).

Large, robust, root-climbing liane to $15 \mathrm{~m}$. Shoot system well differentiated into adherent climbing shoots and free lateral flowering branches; eocaul not observed; seedling with congested leaves similar to adult. Leaves bright to mid-green adaxially, paler abaxially, drying dull green to brownish; petiole $5-14 \times 0.5-1.5 \mathrm{~cm}$, broadly winged, oblong to obovate-oblong, base decurrent to clawed, apex truncate, rounded or auriculate; blade 3-18 $\times 1.5-20.5 \mathrm{~cm}$, ovate to elliptic or lanceolate, apex attenuatemucronate to acute or attenuate, minutely apiculate, base rounded to acute; primary lateral veins arising at c. $50^{\circ}$, intramarginal veins 2 to 4 veins per side of the midrib. Inflorescence solitary, in the axils of middle and distal leaves, sometimes arising on older (foliage) leafless parts, borne on condensed shoots and subtended by cataphylls, the last and longest cataphylls to $3.5 \mathrm{~cm}$ long; peduncle $4-10 \times 0.15-0.2 \mathrm{~cm}$, rather stout, erect, dull orange-yellow. Spathe 4-12 $\times 4-10 \mathrm{~mm}$, ovate, flat to convex, base cordate, clasping the peduncle, apex slightly raised, acute to subacute with a stout mucro, white, somewhat waxy. Spadix stipitate; stipe $2.75-4 \times 0.2-0.25 \mathrm{~cm}$, erect, straight, pale green; fertile portion 12.5-15 × 10-12 mm, ovoid-clavate, mid-yellow. Flowers c. 1-2 mm diam.; with 6 free tepals and 6 stamens. Infructescence with 1-5 berries; fruit 10-17.5 $\times 10-14 \mathrm{~mm}$, obclavate to ovoid or ellipsoid, epidermis of upper part roughened in submature fruits, more or less smooth when ripe, deep green ripening to scarlet; seeds c. 3-6 mm diam., ellipsoid to compressed-globose. - Figs. 7, 8.

Distribution - Thailand (Yala \& Narathiwat). In Malesia: Peninsular Malaysia, Sumatera (Riau Province).

Habitat - Rain forest on granitic or limestone rock along streams in moist evergreen forest on moderate slopes, rarely in swamp forest, 50-1450 m altitude.

Note - The large yellow-and-white inflorescences are distinctive and combined with the long petiole and small blade make $P$. macrocephalus unmistakable. It is most similar 

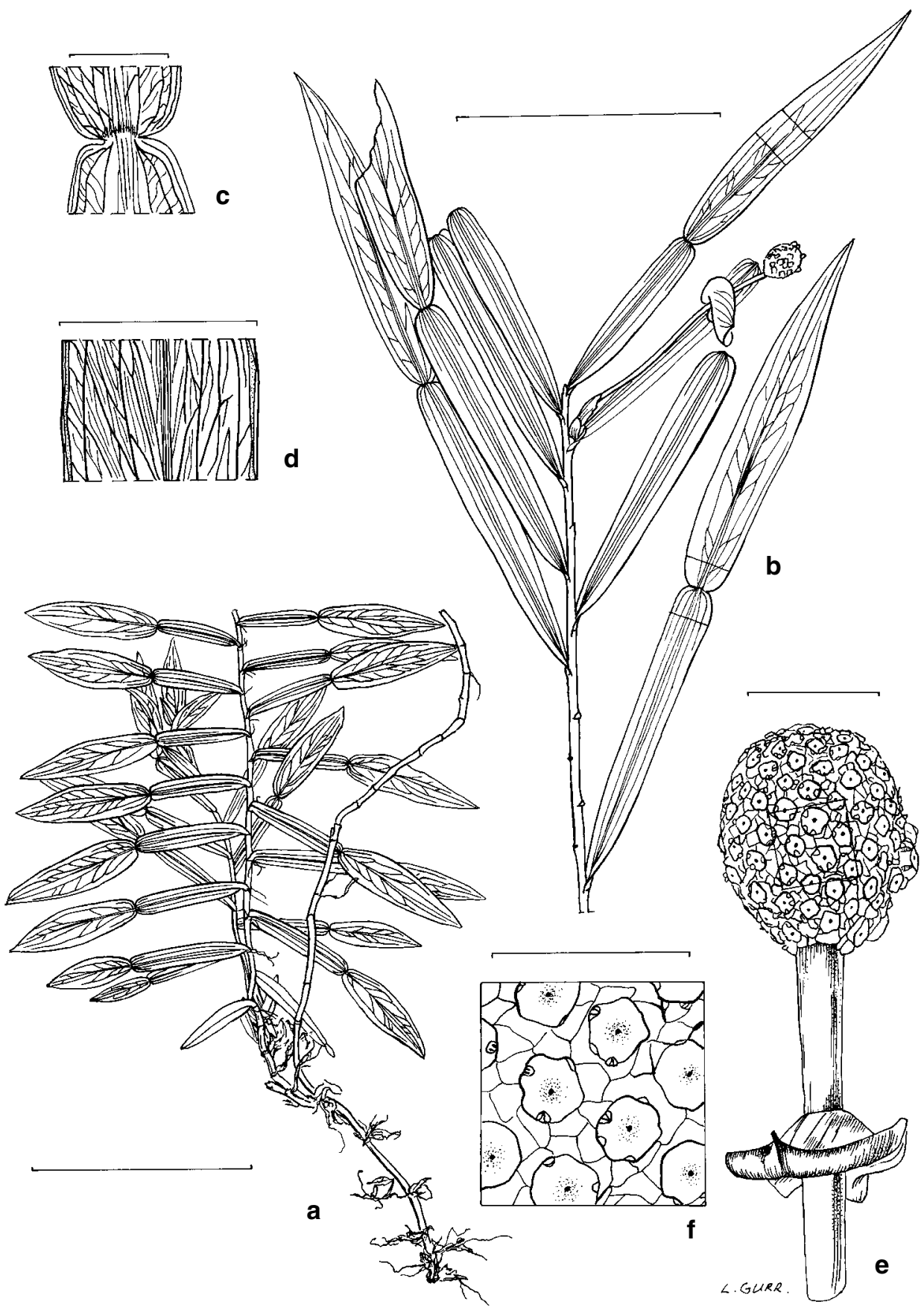

Fig. 7. Pothos macrocephalus. a, juvenile shoots; b, fertile shoot; $\mathbf{c}$, detail of junction of lamina and petiole; d, venation detail; e, inflorescence; $\mathbf{f}$, spadix detail: $\mathrm{a}-\mathrm{f}$, Boyce 1217 . Scale bar: $\mathrm{a}=10 \mathrm{~cm}$; $\mathrm{b}=6 \mathrm{~cm} ; \mathrm{c}=5 \mathrm{~mm} ; \mathrm{d}=1 \mathrm{~cm} ; \mathrm{e}=1 \mathrm{~cm} ; \mathrm{f}=4 \mathrm{~mm}$. 

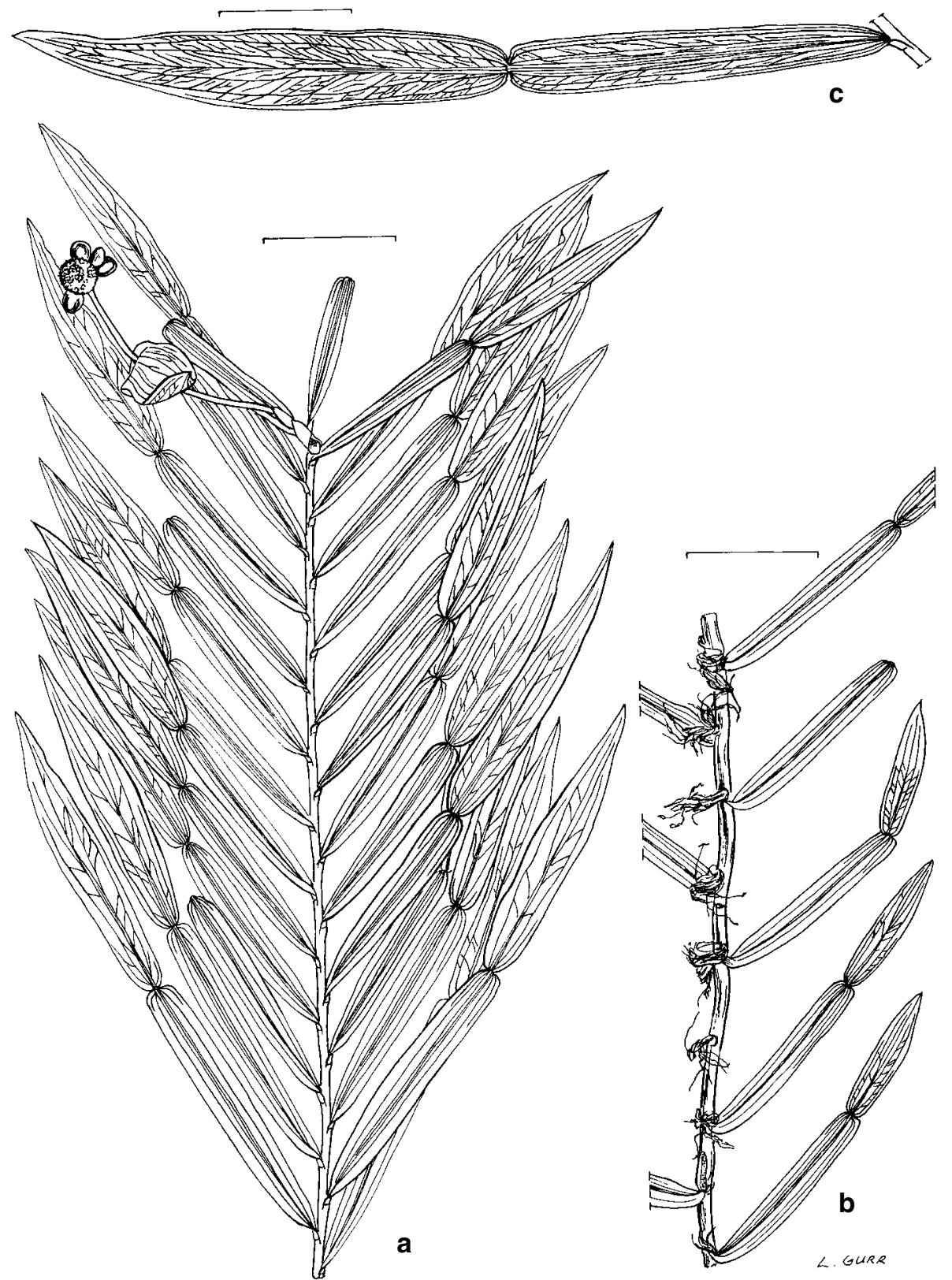

Fig. 8. Pothos macrocephalus. a, fertile shoot; b, sterile mature shoot; c, whole leaf: a-c, Boyce 1217. Scale bar: $\mathrm{a}=4 \mathrm{~cm} ; \mathrm{b}=8 \mathrm{~cm} ; \mathrm{c}=3 \mathrm{~cm}$. 
in appearance to $P$. junghuhnii although the shape of the mature leaves is quite different (compare Figs 6 \& 6a with 5). In Sumatera confusion with P. junghuhnii is possible, although $P$. macrocephalus has the petiole greatly exceeding the blade and tends to be far more floriferous with inflorescences arising at all but the basal-most leaf axils of the flowering branch. Fresh material is separable on inflorescence colour: $P$. macrocephalus has the peduncle orange-yellow, the stipe pale green and the spathe white, while the peduncle and stipe are purple and the spathe is green or purple in $P$. junghuhnii. Sterile $P$. macrocephalus is confusable with $P$. scandens although in the latter the petiole is generally shorter than the blade and generally $P$. macrocephalus is a much more massive plant.

Other specimens examined: PENINSULAR MALAYSIA: Perak, Gua Puteri, Ahmad \& Sidek SA 638 (SING); Perak, Bk. Larut Boyce 693 (K, KEP); Johore, Sg. Kayu, Mawai - Jemaluang Road, Corner SING 29247 (BO, SING); Johore, Kulai, Corner SING 30994 (SING); Johore, Mawai, Corner s.n. (K, SING); Terengganu, Kemaman, Ulu Kajang, Corner s.n. (SING); Perak, Natuloo, Curtis 2895 (K, SING); Kedah, Furtado SING 33050 (A, BO, K, SING); Kelantan, Gua Panjang at Gua Minik, Henderson SING 19557 (SING); Perak, Gua Badak, Lenggong, Henderson SING 23835 (K, SING); Johore, Sg. Kayu, Keah SING 32104 (A, K, SING); Perlis, Bk. Kaki, Kiah SING 35282 (A, BKF, BO, K, SING); Kelantan, Bt. Machang, Gua Musang, Kiew \& Anthonysamy 2858 (UPM); Perak, Goping, Kunstler ('Dr King's collector') 492 (CAL, K); 4327 (BO, CAL, E, K), 6029 (BM, CAL, K, SING); Perak, Ipoh, G. Rapat, Molesworth-Allen 4116 (SING); Pahang, Cameron Highlands, milestone between Tapah and Cameron Highlands, Nicolson 1185 (US); Perak, Ipoh, above Perak Cave Temple, S.C. Chin 999 (KLU); Perak, Bt. Kusan, Wray 4254 (BM, SING). SUMATERA: Riau Prov., Tigapulu Mts, $5 \mathrm{~km} \mathrm{~W}$ of Talanglakat, on Rengat-Jambi road, Bk. Karampal area, Burley et al. 1558 (A, BO, KEP, SING, US); Sumatera Utara, Soedarsono 280 (BO, K); Sumatera Barat, Padang, Telung Kabung, van Borssum Waalkes 1634 (A, BO, K, SING).

\section{Pothos versteegii Engl.}

Pothos versteegii Engl. Nova Guinea 8 (1910) 247; K. Krause, Nova Guinea 8 (1912) 805; K. Krause \& Alderw., Nova Guinea 14 (1927) 210; Hay, Blumea 40 (1995) 409-411, fig.4. - Type: Papua Barat, Mimika/Snow Mountains Prov., Noord River, Alkmaar, 17 Sep 1907, Versteeg 1782 (B, holo; iso L).

Pothos brevispathus Ridl. ('brevispatha'), Trans. Linn. Soc. Lond. 9 (1916) 240. - Type: Papua Barat, Mimika Prov., Puncak Jaya (Mt Carstensz), Utakwa River, Camp I, Nov/Dec 1912, Boden Kloss s.n. (BM, holo).

Pothos ledermannii Engl. \& K. Krause, Bot. Jahrb. Syst. 54 (1917) 74. — Type: Papua New Guinea ('Kaiser Wilhelmsland'), W Sepik Prov., Sepik River, Hunsteinspitze, Ledermann 8333 (B, holo; iso BM, K).

Pothos ledermannii Engl. \& K. Krause var. caudatus Engl. \& K. Krause. ('caudata'), Bot. Jahrb. Syst. 54 (1917) 75. — Type: Papua New Guinea ('Kaiser Wilhelmsland'), W Sepik Prov., Sepik River, Etappenberg, 3 Oct 1912, Ledermann 9001 (B, holo).

Slender hemi-epiphytic root-climbing liane. Shoot system well-differentiated into adherent, non-flowering and free, lateral flowering branches; eocaul and seedling not observed. Leaves dull green, darker adaxially; petiole up to $6 \times 1 \mathrm{~cm}$ when blade absent, otherwise very much reduced, $1 / 16$ to $1 / 20$ of the length of the blade, to $5 \mathrm{~mm}$ wide, flat and lamina-like, linguiform to narrowly lanceolate; blade 8-17 cm $\times 2-6 \mathrm{~cm}$ but very variable in size on a single shoot, narrowly ovate to oblong ovate to somewhat obovate, absent on early leaves of a sympodial module, tip somewhat acuminate, base tapering, acute to slightly retuse; primary lateral veins diverging from the midrib at $c$. $30-60^{\circ}$, intramarginal veins 1 or 2 (or 3 ) on each side, where more than one, the first arising near the base of the blade and running distally to the margin, the second arising about midway and running to the tip. Inflorescence solitary (at any one time) on leafless, perennial, sympodial, repeatedly-flowering, condensed short shoots in distal 


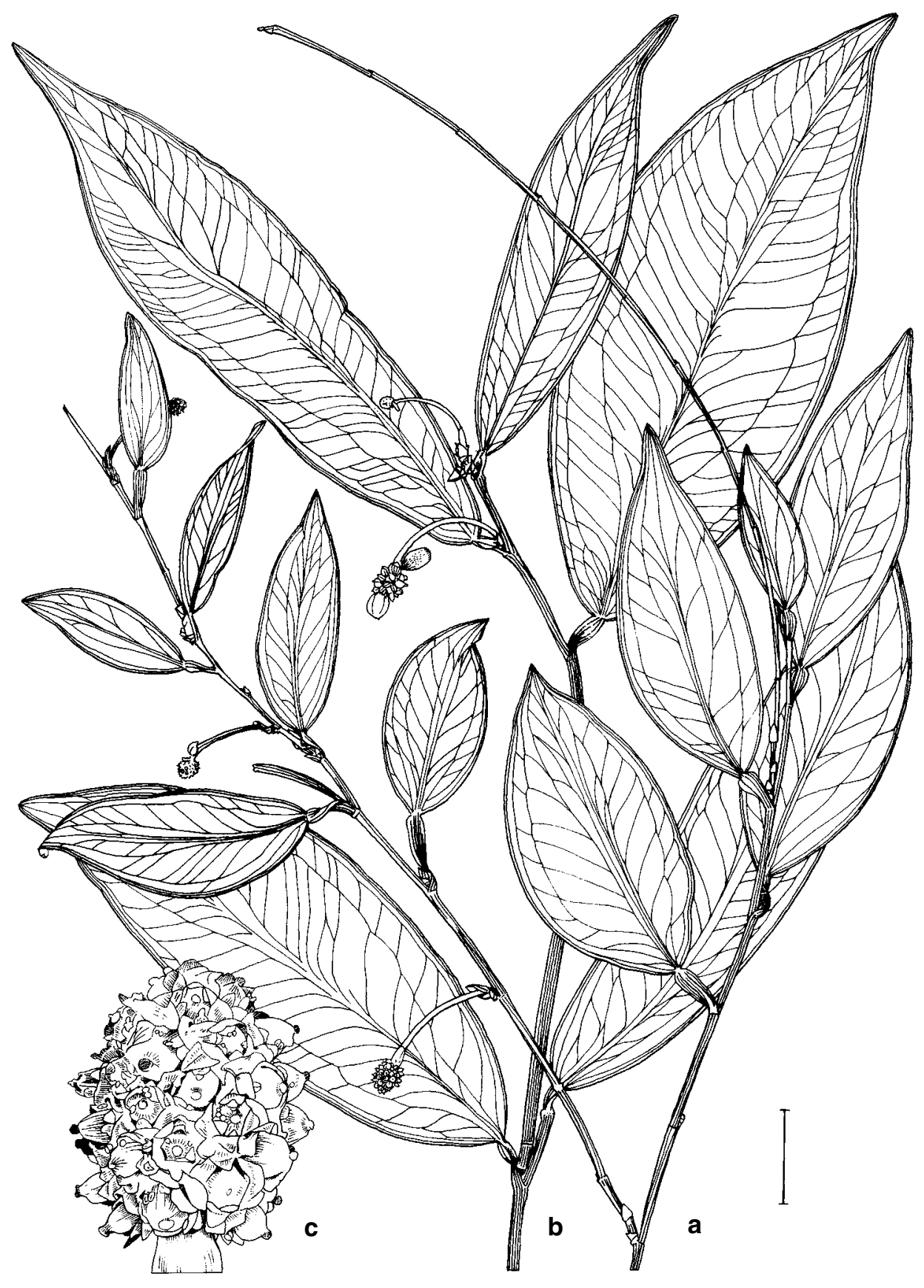

Fig. 9. Pothos versteegii. $\mathbf{a}$, fertile shoot in flower; $\mathbf{b}$, fertile shoot in fruit; $\mathbf{c}$, spadix: a, Boden Kloss s.n.; b-c, Streimann NGF 51738. Scale bar: $\mathrm{a}, \mathrm{b}=2 \mathrm{~cm} ; \mathrm{c}=2 \mathrm{~mm}$. 
leaf axils (these persisting after leaf fall and some inflorescences thus on otherwise naked stem), 1-4 per leafy flowering shoot, subtended by a series of cataphylls, the longest to c. $8 \mathrm{~mm}$ long; peduncle to c. $2.5 \mathrm{~cm}$ long, slender, mostly rather abruptly upcurved near the base, deep purple. Spathe 2-3 $\times 4-5 \mathrm{~mm}$, ovate, reflexed, tip mucronulate, creamy white to yellowish. Spadix sessile, c. $4-7 \times 3-4 \mathrm{~mm}$ subspherical to ovoid, creamy white to yellowish. Flowers c. $1.5 \mathrm{~mm}$ diam, with 6 free tepals and 6 stamens. Infructescence with 1-6 berries; fruit c. $3.5 \mathrm{~mm} \times 3 \mathrm{~mm}$, small, subglobose to ovoid, minutely beaked, red when ripe; seeds not observed. - Fig. 9.

Distribution - Malesia: endemic to New Guinea (recorded rather sporadically and not in eastern parts of Papua New Guinea).

Habitat - Lowland to upper hill rainforest, 40 - $850 \mathrm{~m}$ altitude.

Note - A species easily distinguished by the very reduced petiole, small spadix and small fruits.

Other specimens examined: NEW GUINEA: PAPUA BARAT: Digul/Mimika Prov., van der Sande-Flusse (Beaufort River?), Pulle 360 (L). PAPUA NEW GUINEA: E Sepik Prov., Wagu, Ambunti, Hoogland E Craven 10404 (LAE); Western Prov., Yat, NGF 31973 (LAE); Western Prov., Kiunga, W of airstrip, NGF 34132 (L, LAE); Western Prov., Kiunga, Streimann NGF 51738 (CANB, K, L, LAE, US); Western Prov., Kiunga, 5 miles NW of Kiunga-Rumginae road, Streimann \& Katik LAE 51862 (L, LAE, US).

\section{Pothos zippelii Schott}

Pothos zippelii Schott, Ann. Mus. Bot. Lugd.-Bat. 1 (1863) 131; Engl. in A. \& C. DC., Monogr. Phan. 2 (1879) 86 \& Bot. Jahrb. Syst. 25 (1898) 5 \& in Engl., Pflanzenr. 21 (IV.23B) (1905) 32-34, fig.14; Warb., Bot. Jahrb. Syst. 13 (1891) 268; Hay, Blumea 40 (1995) 416-417, fig.4. — Type: 'New Guinea', Zippel s.n. (L, holo; iso K).

[Pothos nigrescens Zipp. ex Miq., Ann. Mus. Bot. Lugd.-Bat. 1 (1863) footnote \& in synon. p. 131; nom superfl. pro P. zippelii Schott].

Pothos elegans Engl. Bull. Soc. Tosc. Ortic. 4 (1879) 267 \& in Becc., Malesia 1 (1882) 262 \& in Engl., Pflanzenr. 21 (IV.23B) (1905) 34-35. - Type: Papua Barat, Kepala Burung Prov., Arfak Mts, Hatam, Beccari p.p. 1875. (FI, holo; iso B).

Slender root-climbing liane or hemi-epiphyte. Shoot system well-differentiated into adherent climbing shoots and free lateral flowering branches; eocaul and seedling not observed. Leaves drying dull mid-green; petiole lamina-like, about $1 / 4-2 / 3$ of the length of the blade, to c. $1.4 \mathrm{~cm}$ wide, distally rounded to slightly (to pronouncedly) auriculate; blade c. $6-12 \times 2-3.5 \mathrm{~cm}$, elliptic to ovate, tip somewhat to very acuminate, base rounded; primary lateral veins diverging at c. $30-45^{\circ}$, intramarginal veins 2 or 3 on each side of the midrib. Inflorescence solitary, rarely clustered, usually subtended by cataphylls on condensed short shoots in the axils of distal leaves, rarely terminal on leafy shoots; peduncle to c. $10 \mathrm{~cm}$ long, slender, sometimes gradually thickening distally. Spathe c. $1.2-3.5 \mathrm{~cm} \times 6-8 \mathrm{~mm}$, oblong-ovate to lanceolate, reflexed. Spadix sessile to minutely stipitate, to c. 1-2.5 cm long, ovoid-cylindric, c. twice as long as thick. Flowers c. $1.1 \mathrm{~mm}$ diam., with 6 free tepals and 6 stamens. Fruit obovoid, $6-9 \mathrm{~mm}$ long, red when ripe; seeds not observed. - Fig. 10.

Distribution — Solomon Islands (Bougainville). In Malesia: Maluku to New Guinea.

Habitat - Primary to secondary lowland to hill rainforest, 10 - $360 \mathrm{~m}$ altitude.

Note - A collection from near Jayapura, McKee 1911, has a stipitate spadix and much resembles the Australian P. longipes Schott (q.v.). 


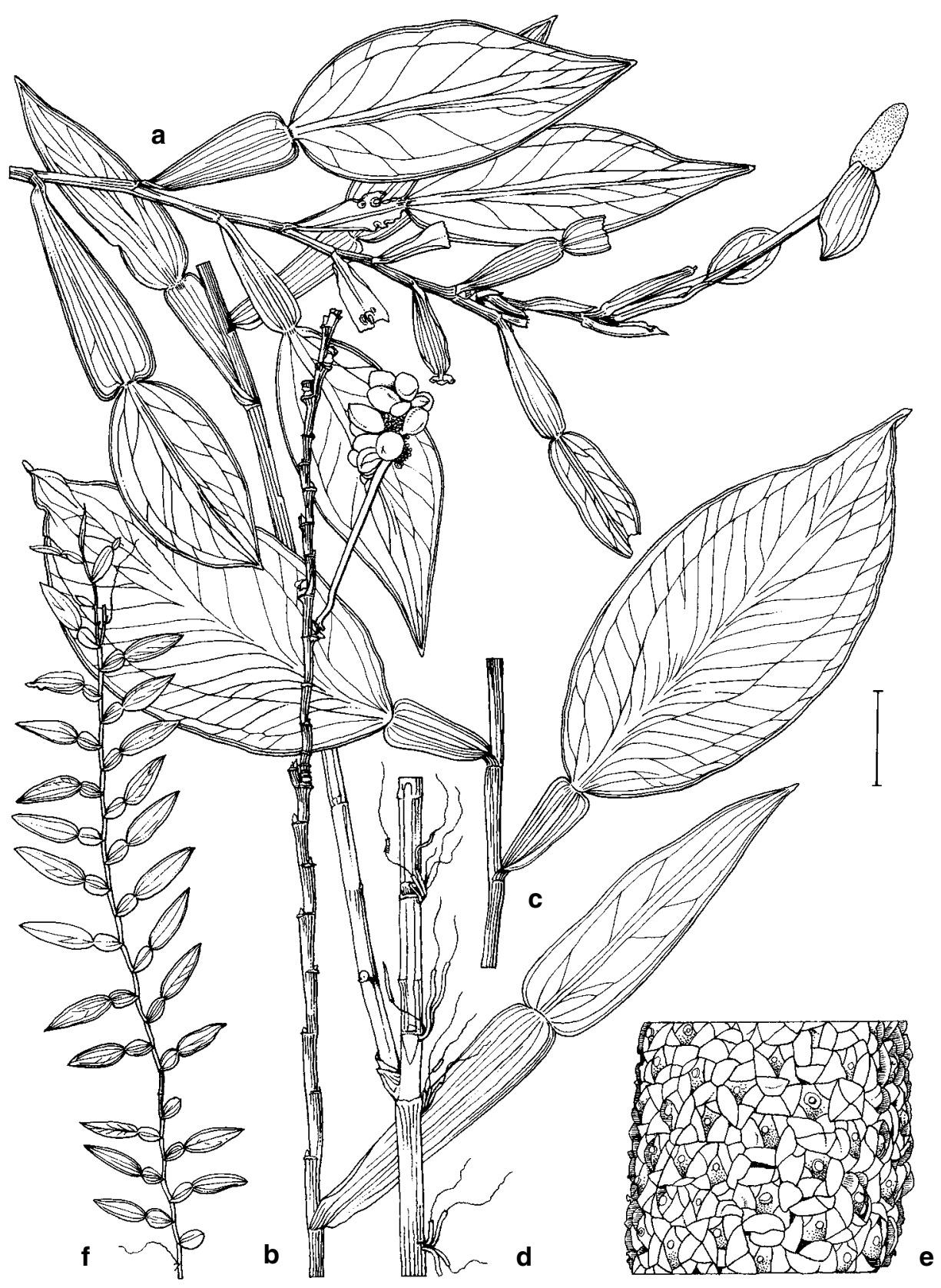

Fig. 10. Pothos zippelii. $\mathbf{a}$, fertile shoot in fruit; $\mathbf{b}$, fertile shoot in flower; $\mathbf{c}$, leaves; $\mathbf{d}$, adult adherent shoot; e, spadix detail; f, juvenile adherent shoot: a \& e, van Royen 4030; b, Isles et al. 31481; c-d, de Vogel 3957; f, Jensen 256. Scale bar: a-d = $2 \mathrm{~cm}$; e $=2 \mathrm{~mm}$. 
Other specimens examined: MALUKU: Halmahera, Beguin 2269 (BO); Aru Is., P. Koboor, Selibatabata, Buwalda 5277 (BO, K); Kasiroeta Is., Batjan, Curran 349 (A); Halmahera, Ekor, Kali Dowora Ina, de Vogel 3126 (BO, L, MO); Bacan Is., G Tuara, near Amasing Kali, de Vogel 3957 (BO, K, L, MO); C Halmahera, Akelamo Oba, de Vogel 4403 (K, L, MO); P. Ceram, Camp 1, Wae Roeatan/Camp 2, Wae Toni, Eyma 3173 (BO); Aru Is., Papahula, Jensen 256 (BO, C); P. Ceram, Wai Seru, Kornassi 1028 (BO); P. Ceram, Kanikeh (Kaniki), Kornassi 1391 (BO); Aru Is., Moseley (Challenger Exped.) s.n. (K); Obi Is., Laiwoei, Kg Baoe, Nedi 524 (BO); P. Ceram, Suharno 189 (BO); Halmahera Is., Jailolo Distr., Kg Pasir Putih, Taylor 263 (A), Taylor 383 (A, K); Halmahera Is., Tapayo, 20 km SE of Dodinga, Darco/Modul logging camp, Whitmore at al. 3662 (BO, K). NEW GUINEA: PAPUA BARAT: Biak Is., Sorida airstrip, Brongersma s.n. (L); Jayapura Prov., Jayapura ('Hollandia'), Kota Baru, McKee 1911 (K, L); Biak Is., 1 km NW of Mokmer airport, Nicolson 1593 (B, K, L, LAE, P, US); Kepala Burung Prov., road from Steenkool to Tembuni, km 4.8, van Royen 4030 (K, L, LAE). PAPUA NEW GUINEA: New Britain, W New Britain Prov., Hoskins, SE slopes Mt Uluwun, LAE 58597 (L, LAE); New Britain, W New Britain Prov., Gasmata, 2 miles W of Fulleborn Harbour, Isles et al. NGF 31481 (BRI, L, LAE, US); Gulf Prov., Mt Bosavi, N side, Jacobs 8986 (L); Bougainville, Buin, Kugumaru, Kajewski 1808 (BM, BRI, P); Milne Bay Prov., Raba-Raba, MI road to Mt Suckling (Manurep), Katik NGF 46898 (BRI, L, LAE, US); Mussau, Koie E Ølsen 1512 (C, LAE).

\section{Pothos papuanus Becc. ex Engl.}

Pothos papuanus Becc. ex Engl. Bull. Soc. Tosc. Ortic. 4 (1879) 267 \& in Becc., Malesia 1 (1882) 261, t.16, figs5-7 \& Bot. Jahrb. Syst. 9 (1887) 193 \& in K. Schum. \& Hollrung, Fl. Kais. Wilh. Land (1889) 19 [p.p.; see under P. zippelii] \& Bot. Jahrb. Syst. 25 (1898) 3 \& in Engl., Pflanzenr. 21 (IV.23B) (1905) 34; Warb., Bot. Jahrb. Syst. 13 (1891) 267; Alderw., Bull. Jard. Bot. Buitenzorg III, 4 (1922) 337; K. Krause \& Alderw., Nova Guinea 14 (1927) 211; Hay, Blumea 40 (1995) 415-416. — Type: Papua Barat, Kepala Burung Prov., Segun ('Sangion') Bay, 9 Apr 1872, Beccari p.p. 16 (FI, holo).

Pothos albertisii Engl. Bull. Soc. Tosc. Ortic. 4 (1879) 267 \& in Becc., Malesia 1 (1882) 262, t.16, figs 8 \& 9 \& Bot. Jahrb. Syst. 25 (1898) 4 \& in Engl., Pflanzenr. 21 (IV.23B) (1905) 34; K. Schum. \& Hollrung, Fl. Kais. Wilh. Land (1889) 19; K. Schum. \& Lauterb., Fl. Schutzgeb. Südsee (1901) 209; K. Krause, Nova Guinea 8 (1912) 805; K. Krause \& Alderw., Nova Guinea 14 (1927) 211; Hay in Johns \& Hay, Stud. Guide Monocot. Papua New Guinea 1 (1981) 66, fig. 27 \& Aroids of Papua New Guinea (1990) fig. 32, pl.14 a \& c. - Type: Papua New Guinea, Western Prov., Fly River, 1879, d'Albertis s.n. (FI, holo; iso B).

Pothos quinquevenosus Alderw., Bull. Jard. Bot. Buitenzorg III, 4 (1922) 336; K. Krause \& Alderw., Nova Guinea 14 (1927) 210. - Type: Papua Barat, Bonggo Range, Mamberamo, nr Prauwen Bivak, 5 May 1890, Lam 1041 (BO, holo, photo LAE, NSW; iso $\mathrm{L})$.

Vigorous slender root-climbing liane or hemi-epiphyte. Shoot system welldifferentiated into adherent climbing shoots and free lateral flowering branches; eocaul and seedling not observed. Leaves pale green, drying dull greyish green; petiole c. 4-8 cm long, to c. $2 \mathrm{~cm}$ wide, lamina-like, c. $1 / 3$ the length of to equalling the blade, distally truncate to strongly auriculate, rarely rounded; blade c. $6-12 \times 1.2-3.5 \mathrm{~cm}$, narrowly elliptic to (ob)lanceolate, tip tapering to a point but hardly acuminate, base rounded; primary lateral veins diverging at c. $30^{\circ}$, intramarginal veins $2-5$ on each side of the midrib, the inner ones arising about midway along its length. Inflorescence solitary or occasionally clustered (to three together), usually lateral on a (sometimes sympodially branched) short shoot in distal leaf axils and subtended by cataphylls, the last and longest of these c. $3 \mathrm{~cm}$ long, rarely terminal on a leafy shoot; peduncle to c. $9 \mathrm{~cm}$ long, mostly rather robust, gradually increasing in thickness distally, purple-black. Spathe to c. $4 \times 1.2 \mathrm{~cm}, 1 / 3$ to c. $4 / 5$ the length of the spadix, reflexed, oblong-ovate to oblong-lanceolate, pale green to purplish brown. Spadix sessile, $2-4 \mathrm{~cm} \times 3-4 \mathrm{~mm}$, 


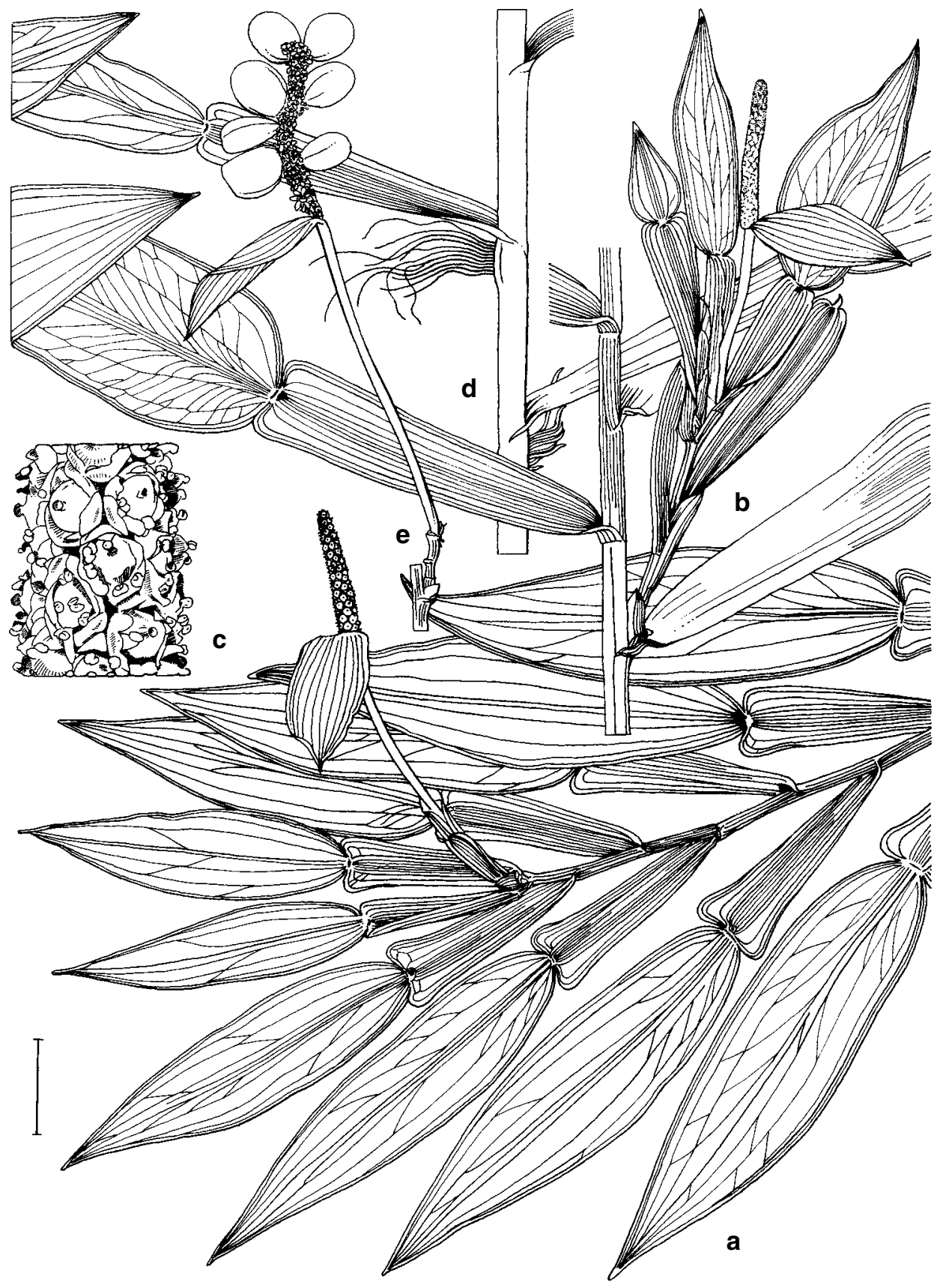

Fig. 11. Pothos papuanus. $\mathbf{a}$, fertile shoot in flower; $\mathbf{b}$, fertile shoot in fruit; $\mathbf{c}$, spadix detail; $\mathbf{d}$, adult adherent shoot; e, infructescence: a, c \& e, Nicolson 1561; d, Main 460. Scale bar: a, b,d,e = 2 cm; $\mathrm{c}=2.7 \mathrm{~mm}$. 
usually more than six times as long as thick, cylindric to somewhat tapering, blunttipped, yellow. Flowers c. $1.1 \mathrm{~mm}$ diam, with 6 free tepals and 6 stamens; fruit to $2 \mathrm{~cm}$ $\times 9 \mathrm{~mm}$, ovoid, ripening through yellow to deep red; seeds not observed. - Fig. 11 .

Distribution - Solomon Islands. In Malesia: widespread in New Guinea.

Habitat - Well-drained to swampy, primary to secondary lowland to lower montane rainforest, up to $1500 \mathrm{~m}$ altitude.

Notes - Pothos papuanus manifests a wide range of vigour, with $P$. quinquevenosus and $P$. albertisii falling within the range.

The young shoots and fruits are reported to be edible after cooking.

Other specimens examined: NEW GUINEA: PAPUA BARAT: Biak, Yapen Is., Sarurai, near Serui, Aet \& Idjan 187 (BO); Jayapura Prov., Taritatau ('Idenburgh') River, Bernhard Camp, Brass 13943 (A, BRI, L, MO), Brass 13958 (A, BRI, L); Jayapura Prov., Bonggo Range, nr Albatross Bivak, Docters van Leeuwen 9661 (BO), Docters van Leeuwen 11370 (BO, K, L, SING); Jayapura Prov., Jayapura ('Hollandia'), Gjellerup 512 (L); Napan Prov., Cenderawasi, Wati, Ijiri \& Niimura 632 (L); Jayapura Prov., Jayapura ('Hollandia'), Tami-Moding, Kalkman 3429 (L, LAE); Jayapura Prov., Bonggo Range, Mamberamo, nr Prauwen Bivak, Lam 955 (L), Lam 1036 (L); Kepala Burung Prov., Sorong, Remoe, Main 460 (A, BO, SING); Jayapura Prov., Taritatau (Idenburgh) River, Bernhard Camp, Meijer Drees 309 (BO, K, L), Meijer Drees 324 (A, BO, K, L); Jayapura Prov., Lake Sentani, near Jayapura ('Hollandia') airport, Nicolson 1561 (B, K, L, LAE, P, US). PAPUA NEW GUINEA: E Sepik Prov., Sepik River, Bateson 15 (K); Milne Bay Prov., Maneau Range, Mt Dayman, Brass 23440 (LAE); Morobe Prov., Sattelberg, Boanga, Clemens 8127 (B); Morobe Prov., Manki Ridge, Conn \& Kairo 147 (L, LAE); Madang Prov., Aiome to Ramu River, Coode \& Katik, NGF 32785 (K, L, LAE); Madang Prov., Road E of Aiome, Frodin NGF 26941 (L, LAE, US); E Sepik Prov., 'Kaiser Wilhelmsland', Augusta River, Hollrung 637 (K); Morobe Prov., Golden Pines logging road, LAE 62112 (LAE); E Sepik Prov., 'Kaiser Wilhelmsland', Jagei River, Lauterbach 533 (B); E Sepik Prov., Angoram, Mindimbit, near Timbunke, Sepik River, Leach NGF 34273 (LAE, NSW, US); E Sepik Prov., 'Kaiser Wilhelmsland', Sepik River, Ledermann $6717 a$ (K); E Sepik Prov., 'Kaiser Wilhelmsland', Sepik River, Ledermann 7176 (K); Western Prov., Kiunga, Fly River, Millar NGF 35464 (A, BRI, CANB, K, L, LAE, US); Madang Prov., Wabba ('Wabbe'), Schlechter 16391 (P); Madang/ Eastern Highlands, Raniget, Schlechter 17686 (P); Madang/Eastern Highlands Prov., Ramu River (Keneyia), Schlechter 18353 (P); E Sepik Prov., Ambunti, Townsend 102 (LAE). SOLOMON ISLANDS: Santa Ysabel, SW Santa Ysabel, Pilema Bay, Beer's collectors BSIP 6496 (BSIP, K, L, LAE, SING); Guadalcanal, W Guadalcanal, Vuragob area, Wanderer Bay, Boraule et al. BSIP 9052 (BSIP, K, L, LAE, SING); Guadalcanal, SW Guadalcanal, Wandered Bay area, Fa' arodo et al. BSIP 12164 (BSIP, K, L, LAE, SING); Malaita, SE Malaita, Su'u area, Mauriasi et al. BSIP 13536 (BSIP, K, L, LAE, SING); Guadalcanal, NC Guadalcanal, Tina - Toni River area, Nakisi \& Babala BSIP 8240 (BSIP, K, L, LAE, SING); Guadalcanal, SE Guadalcanal, Avu Avu Mission Station, Runikera et al. BSIP 9916 (BSIP, K, L, LAE, SING); New Georgia, Waterhouse 302 (BRI, K, NSW).

\section{Pothos longipes Schott}

Pothos longipes Schott, Aroideae (1856-1857) 23, t. 47 \& Prodr. Syst. Aroid. (1860) 568-569; F. Muell., Fragm. Phytogr. Austr. 8 (1874) 187; Engl. in A. \& C. DC., Monogr. Phan. 2 (1879) 87 \& Bot. Jahrb. Syst. 25 (1898) 4 \& in Engl., Pflanzenr. 21 (IV.23B) (1905) 36; F.M. Bailey, Comprehensive Cat. Queensland Pl., (1913) 579; Domin, Biblioth. Bot. $20(85,4)$ (1915) 502; C.T. White, Contrib. Arnold Arb. 4 (1933) 12; Evans, Contrib. N.S.W. Nat. Herb. Flora Series 21-22 (1962) 8; Rotherham et al., Fl. Pl. N.S.W. \& Queensland (1975) 107, pl. 337; Williams, Native Pl. Queensland 1 (1979) 242, unnumbered plate \& 3 (1987) 260, unnumbered plate; Beadle, Stud. Fl. NE N.S.W. (1987) 969, fig.424A; Jones \& Gray, Climbing Pl. Austr. (1988) 312, unnumbered plate p.320; Stanley in Stanley \& Ross, Fl. SE Queensland 3 (1989) 271; Hay in Harden, Fl. N.S.W. 4 (1993) 32, unnumbered fig. \& Blumea 40 (1995) 413-415. - Type: Australia, New South Wales, Port Macquarie, Wilson River, Backhouse s.n. (K, holo). 
Pothos australasicus F. Muell., Fragm. Phytogr. Austr. 1 (1858) 62; Schott, Bonplandia 7 (1859) 104. - Type: Australia, Queensland, Pine River, Hill s.n. (MEL, lecto, selected by Hay (1995)).

[Pothos cylindricus sensu auct. non C. Presl: Benth., Fl. Austr. 7158 (1878) 104, in synon.]

[Pothos loureiroi ('loureirii') sensu auctt. non Hook. \& Arn.: Benth., Fl. Austr. 7 (1878) 158; F.M. Bailey, Syn. Queensland Fl. (1883) 570 \& Queensland Fl. 5 (1902) 1698; Moore \& Betche, Handb. Fl. N.S.W. (1893) 429].

Pothos brownii Domin, Fedde Rep. 10 (1911) 58 \& Biblioth. Bot. 20 (85,4) (1915) 501; F.M. Bailey, Comprehensive Cat. Queensland Pl. (1913) 579. - Type: Australia, Queensland, Rockingham Bay, Dallachy s.n. (K, lecto; isolecto MEL, selected by Hay (1995: 413)).

Slender to moderately robust, very variable as to vigour, root-climbing liane or hemiepiphyte. Shoot system well-differentiated into adherent, climbing shoots and free, lateral flowering branches; eocaul not observed; seedling with congested leaves similar in shape to adult, becoming progressively larger as shoot extends. Leaf rather glossy dark green above, paler to somewhat yellowish beneath; petiole $2-12 \mathrm{~cm} \times 4-14$ $\mathrm{mm}$, usually exceeding the blade in length, oblanceolate, distally rounded to truncate to strongly auriculate; blade $1.5-15 \mathrm{~cm} \times 3-15 \mathrm{~mm}$, elliptic to narrowly lanceolate, somewhat acuminate-tipped, base rounded; primary lateral veins diverging at c. $30-40^{\circ}$, intramarginal veins 1 or 2 (or 3 ) on each side of the midrib. Inflorescence solitary, less commonly paired, in the axils mostly of distal leaves of a flowering branch and subtended by cataphylls, rarely terminal on leafy branchlets; peduncle rather stout, c. 2-5 cm long. Spathe c. 1.5 -4 cm $\times 5-9 \mathrm{~mm}, \pm$ lanceolate, wide opening to reflexed, purple-black to greenish. Spadix stipitate, more rarely sessile; stipe to c. 3 $\mathrm{cm}$ long and sometimes subequalling the spadix in length (particularly in individuals of very slender dimensions); fertile portion of spadix to c. $6 \mathrm{~cm}$ long, slender to rather stoutly cylindrical, yellow to purplish. Flowers c. $1.3 \mathrm{~mm}$ diam., with 6 free tepals and 6 stamens. Infructescence with many berries; fruit $8-13 \mathrm{~mm}$ long, ovoid, red when ripe; seeds not observed. - Fig. 12.

Distribution - Eastern Australia, from northeastern Queensland to the New South Wales North Coast region.

Habitat - In rainforest at low altitudes in the southern part of the range, extending, in warmer latitudes, into montane forest to c. $1000 \mathrm{~m}$ alt.

Notes - Pothos longipes is evidently closely related to P. papuanus (q.v.), differing from it chiefly in the petiole usually being longer than the blade (though this is rarely the case in P. papuanus, and rarely not the case in P. longipes), and in the usually stipitate spadix (though likewise this is rarely the case in $P$. papuanus and rarely not the case in $P$. longipes). There is rather wide geographical disjunction between the two, and some ecological differentiation, i.e., tolerance of cooler climates in P. longipes.

The relationship to $P$. cylindricus is clearly close, although $P$. longipes is readily distinguished by the stipitate spadix and by the inflorescences arising in the axils mostly of distal leaves of a flowering branch, only rarely terminal on leafy branchlets.

Engler (1905) grouped P. longipes with P. cylindricus in his series Longipedes, separated from the other three series of subgenus Pothos by the presence of foliage leaves on the ultimate flowering branches between the basal cataphylls and the terminal inflorescence. Engler (1879) had made a similar grouping earlier but without erecting formal supraspecific taxa at that rank. In other series the inflorescence is immediately subtended by cataphylls, and is considered lateral to the leafy branch that bears it. This distinction breaks down in $P$. longipes where one may find in the same specimen 


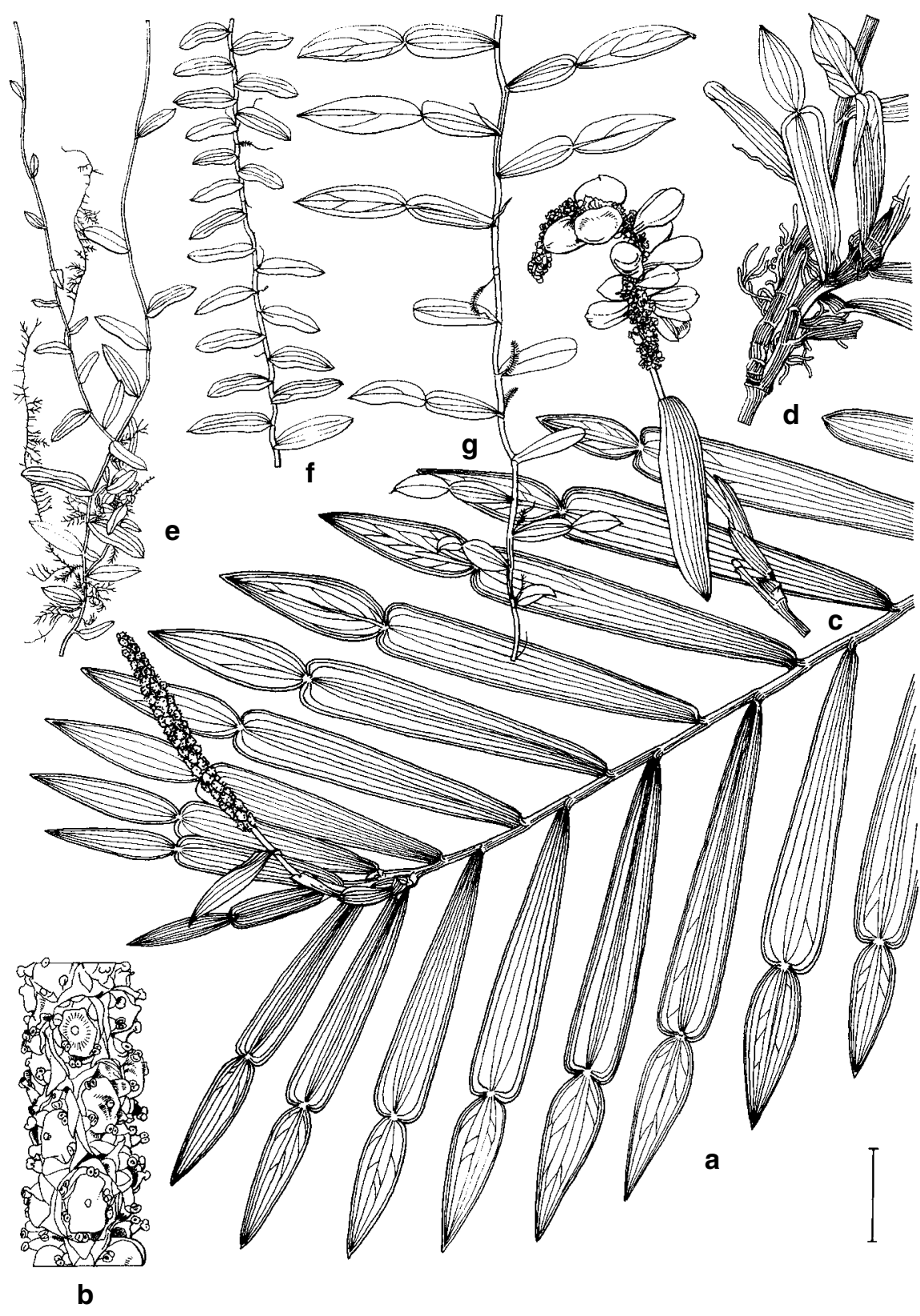

Fig. 12. Pothos longipes. a, fertile shoot; $\mathbf{b}$, spadix detail; $\mathbf{c}$, infructescence; $\mathbf{d}$, adult adherent shoot, branching detail; $\mathbf{e}-\mathbf{g}$, juvenile adherent shoots of increasing maturity: $\mathrm{a}-\mathrm{b}$, Brass 20179; c, Kajewski 1432; d, Helms 1155; e-g, Blake 21595. Scale bar: a, c-g, $=2 \mathrm{~cm} ; \mathrm{b}=3.5 \mathrm{~mm}$. 
inflorescences immediately subtended by cataphylls and borne laterally on a leafy shoot, and inflorescences with foliage leaves between the spathe and the cataphylls. While it may thus appear that the inflorescence is lateral or terminal in this species, in fact inflorescences are always terminal on the shoots that bear them but (foliage) leaves may or may not develop on those shoots.

Selected other specimens examined (this species has been collected on very numerous occasions): AUSTRALIA: NEW SOUTH WALES: Dorrigo, Boorman s.n. (L, NSW); Hastings River, Fraser s.n. (BM, NSW); Wide Bay, Dunnbirrbin River, Leichhard 246 (P); Bruxner Park, near Coffs Harbour, Martin s.n. (K), Red Scrub, by Rocky Creek, foot of Nightcap Range, Melville 3321A (K, MEL); E Dorrigo plateau, Never Never Creek, Melville 3389 (K, MEL, NSW); Clarence River, Moore 132 (K); Tweed Range, Wiangaree S.F., Schodde 5617 (BRI, CANB, K, L, MEL, NSW, US); QUEENSLAND: Mt Glorious, Blake 21595 (BRI, MO); Rockhampton, Bailey s.n. (MO); N Kennedy Distr., foot of Mt Bartle Frere, near Josephine Creek, Blake 9807 (BRI, K, L); Mt Glorious, Blake 12686 (BRI, K); Cook Distr., Boonjee, near Malanda, Blake, 15253 (A, BRI); Moreton Distr., McPherson Range, Blake 15383 (A); Wide Bay Distr., Montville, Blake 15389 (BRI, K); N Kennedy Distr., near Tully, along Jarra Creek, Blake 19710 (A, BRI, K, L); Cook Distr., Mossman, entrance to Mossman Gorge, Blake 19755 (BRI, K); Cape York Peninsular, Upper Parrot Creek, Annan River, Brass 20179 (A, BRI, K, L); Dalrymple Heights, Clemens s.n. (A, K); Along road from Atherton to Main Coastal Highway, along Palmerston Highway, Henrietta Falls, Croat 52597 (MO); Mt Dryander, Fitzalan s.n. (K); Pine River, Hill s.n. (K); Currumbin beach, Jackson s.n. (K); Daintree River, Kajewski 1432 (A, BRI, K, P); Montville, Blackhall Range, N of Brisbane, Longman s.n. (K); Conondale Range (State Forest 274 Conondale), Bundaroo logging area, near Funnels Hut road, McDonald \& Williams 3664 (BRI, K); D'Aguilar Range near Mt Glorious, Moriarty 873 (BRI, CANB, K); Mackay ('Port Mackay'), Nernst s.n. (K); Mt Wolvi, c. 15 km NE of Kin Kin, Sharpe 4534 (BRI, NSW); Mudgeeraba, Shirley s.n. (BRI, US); Trinity Bay, von Mueller s.n. (MEL, SING); Pine River, von Mueller s.n. (A); Armidale, Parrot, von Mueller s.n. (K); Davies Creek, Webb \& Tracey 5575 (BRI, NSW).

\section{Pothos cylindricus $C$. Presl}

Pothos cylindricus C. Presl, Epimel. Bot. (1851) 243; Schott, Aroideae (1856-1857) 23, t.48 \& Prodr. Syst. Aroid. (1860) 569; Miq., Flora Ned. Indië 3 (1856) 180; Engl. in A. \& C. DC, Monogr. Phan. 2 (1879) 86-87 \& in Engl., Pflanzenr. 21 (IV.23B) (1905) 36; Merr., Enum. Philippine Pl. 1 (1922) 172. — Type: Philippines, Manila, 1836-1839, Cuming 914 (PRG, holo; iso BM, E, FI, G, K, L, MO, P).

Slender to moderately robust, root-climbing liane. Shoot system well-differentiated into adherent, climbing shoots and free, lateral flowering branches; eocaul not observed; seedling with congested leaves similar in shape to adult, but with blade elliptic and as long as petiole, becoming progressively larger as shoot extends. Leaf dull pale green above; petiole $2-15 \mathrm{~cm} \times 7-14 \mathrm{~mm}$, exceeding the blade in length, oblanceolate, distally rounded to truncate to auriculate; blade $(0.3-) 1.5-5.5 \mathrm{~cm} \times(2-) 3-25 \mathrm{~mm}$, elliptic to narrowly lanceolate, somewhat acuminate-tipped, base rounded; primary lateral veins diverging at c. $30-40^{\circ}$, intramarginal veins 2 (or 3) on each side of the midrib. Inflorescence solitary, terminal on leafy branchlets; peduncle rather stout, c. $2-5 \mathrm{~cm}$ long. Spathe c. 6-11 cm × 6-10 mm, \pm lanceolate, wide opening to reflexed, purpleblack to greenish. Spadix sessile, $4.8-12 \mathrm{~cm} \times 5-9 \mathrm{~mm}$, rather stoutly cylindrical, brownish purple. Flowers c. $1.3 \mathrm{~mm}$ diam., with 6 free tepals and 6 stamens. Infructescence with many berries, usually twisted; fruit $1-2 \mathrm{~cm} \times$ c. $8 \mathrm{~mm}$ long, obovoid, red when ripe; seeds ellipsoid, c. $1 \mathrm{~cm} \times 6 \mathrm{~mm}$, mid-brown. - Fig. 13.

Distribution - Malesia: Borneo (two records, both from Sabah), Sulawesi (a single record from Morowali prov.) and the Philippines (widespread).

Habitat - Primary and secondary lowland to upper hill forest, often in well-drained positions, 40-900 $\mathrm{m}$ altitude.

Note - Very close to $P$. longipes, but readily distinguished by the sessile spadix and in flowering only terminally on leafy branches (c.f. P. longipes). Pothos cylindricus is 


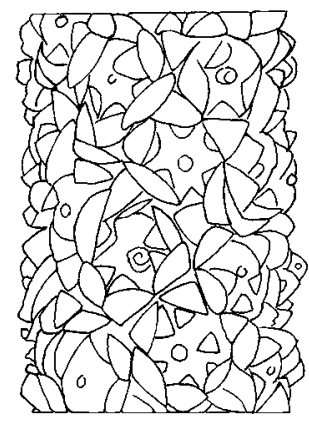

b

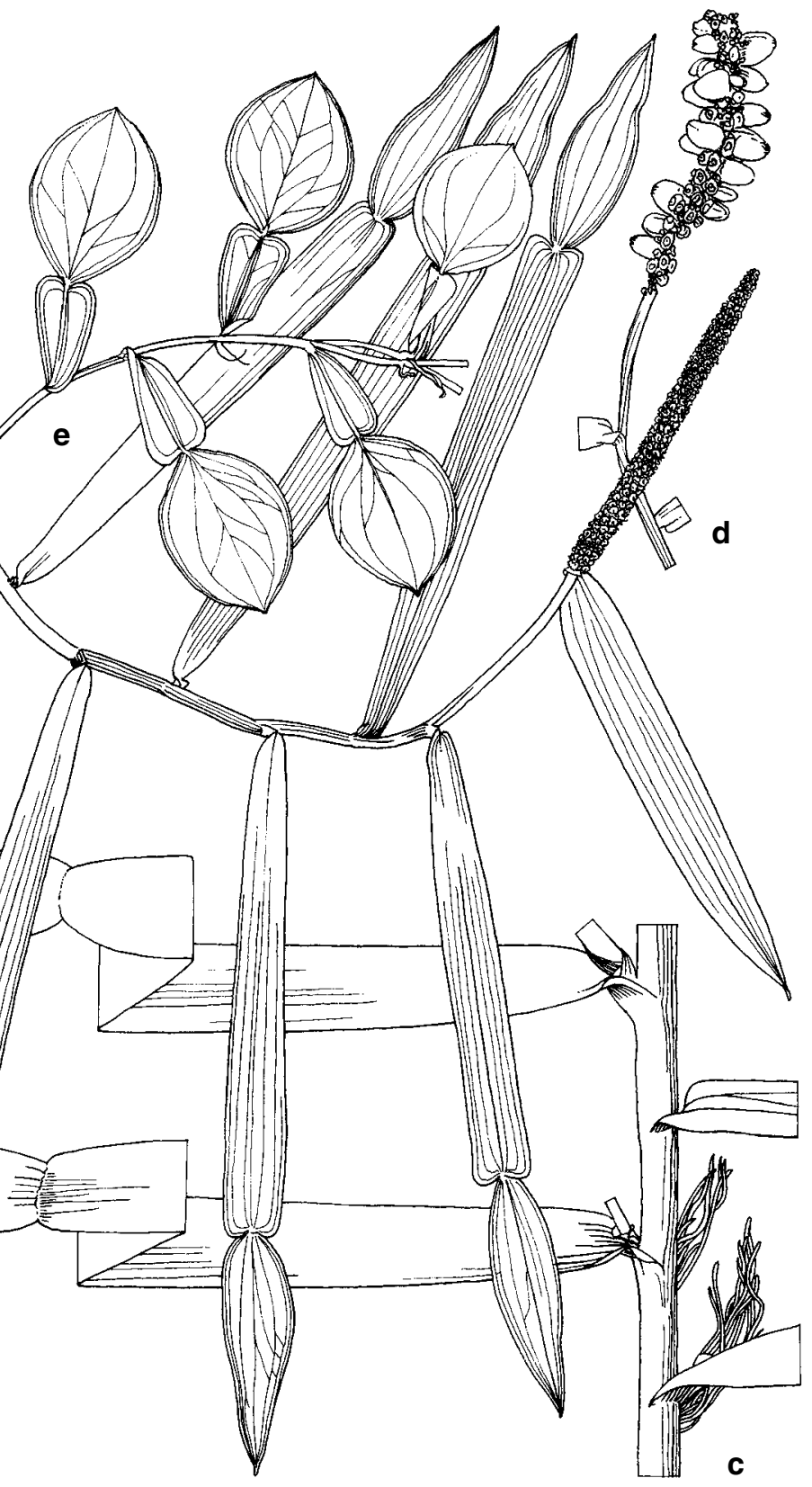

Fig. 13. Pothos cylindricus. a, fertile shoot; $\mathbf{b}$, spadix detail; c, adult adherent shoot; $\mathbf{d}$, infructescence; e, juvenile adherent shoot: $\mathrm{a}-\mathrm{b}$, Nicolson 707; c: Nicolson 720; d, Wenzel 387; e, Nicolson 817. Scale bar: $\mathrm{a}, \mathrm{c}-\mathrm{e}=2 \mathrm{~cm} ; \mathrm{b}=2.5 \mathrm{~mm}$. 
evidently also very near to $P$. papuanus (also with a sessile spadix) although separable by the inflorescence always terminal on a leafy shoot (usually lateral on a sometimes sympodially branched short shoot in distal leaf axils in P. papuanus) and the spathe lanceolate (oblong-ovate to oblong-lanceolate in P. papuanus).

Other specimens examined: BORNEO: SABAH: Kinabatangan, Tamegang timber camp, near K. Pangkaian, Kokawa \& Hotta 1300 (K, KYO, P); Lahad Datu, Danum valley, side of tractor path cut in 1989, Maikin \& Lideh SAN 131103 (E, SAN). PHILIPPINES: Samar, Kadapnan, Bo. Bantayan, Oras, Castro \& Arionuevo PNH 5721 (A, PNH); Luzon, Sorsogon, Curran FB 12250 (K, US); Negros, Negros Oriental, Sibulan, Malanggo Sur, Edaño PNH 6774 (PNH); Luzon, Sorsogon Prov., Mt Juban, Edaño PNH 37154 (BM, K, PNH); Luzon, Sorsogon, Irosin (Mt Bulusan), Edaño \& Gutierrez PNH 37822 (A, PNH); Leyte, Leyte Prov., Palo, Elmer 7240 (A, E, K); Luzon, Camarines Sur, Mt Isarog, Madulid 6776 (MO); Luzon, Albay Prov., Mt Mayon, Madulid \& Reynoso PNH 121125 (PNH); Panay, Antique Prov., McGregor, BS 32451 (SING); Mindanao, Davao Prov., Compostela, Maparat Barrio, 70 km NE of Davao, Nicolson 707 (US); Mindanao, Davao Prov., Bagio, Mr Onglionto's land, Nicolson 713 (US); Mindanao, Davao Prov., Mampising, behind Apocon School, Nicolson 720 (US); Luzon, Sorsogon, Mt Bulusan, SE side, near Lake Bulusan, Nicolson 759 (US); Leyte, Putok Barrio, near lumber camp about $22 \mathrm{~km}$ SW of Tacloban, Nicolson 817 (US); Mindanao, Davao Prov., Mayo Bay, Piper BS 481 (US); Luzon, Camarines, Sagnay, Ramos BS 22143 (K, US); Leyte, Wenzel 387 (BM, MO, US); Mindanao, Davao Prov., Santa Cruz, Williams 2937 (K, US). SULAWESI: Morowali Prov., Grimes 1217 (BM, K).

\section{Subgenus Allopothos}

Pothos subg. Allopothos Schott, Aroideae (1856-1857) 24. - Pothos sect. Allopothos Engl. in A. \& C. DC., Monogr. Phan. 2 (1879) 88. - Type: Pothos cumingianus Schott (lecto selected here; $=$ P. inaequilaterus). [The first species treated under Allopothos by Schott (loc. cit.)]

Pothos series Longivaginati Engl. in Engl., Pflanzenr. 21(IV.23B) (1905) 22. - Type: Pothos inaequilaterus (C. Presl) Engl. (lecto selected here). [The first species treated under Longivaginati by Engler (loc. cit.)].

Pothos series Brevivaginati Engl. in Engl., Pflanzenr. 21(IV.23B) (1905) 22. - Type: Pothos thomsonianus Schott). [The only species Engler recognised in the series].

Pothos series Goniuri (C. Presl) Engl. in Engl., Pflanzenr. 21(IV.23B) (1905) 22. - Type: Pothos luzonensis (C. Presl) Schott. [The type of Goniurus C. Presl].

\section{'Allopothos Supergroup'}

\section{Pothos tener Wall.}

Pothos tener Wall. in Roxb., Fl. Ind. 1 (1820) 454 ('tenera'). - Scindapsus arborum C. Presl, Epimel. Bot. (1851) 242. - Scindapsus tener (Wall.) C. Presl, Epimel. Bot. (1851) 242. [Pothos gracilis Roxb., Fl. Ind. 1 (1820) 454; Schott, Aroideae (1856-1857) 24, t.52 \& Prodr. Syst. Aroid. (1860) 572-573; Miq., Flora Ned. Indië 3 (1856) 181-182; Engl. in A. \& C. DC, Monogr. Phan. 2 (1879) 91-92, nom. illeg., non Pothos gracilis Rudge (1805)]. - Type: Adpendix arborum Rumph., Herb. Amb. 5 (1747) t.181, fig.2, see below.

Pothos rumphii Schott in Schott \& Endl., Melet. Bot. (1832) 21 \& Aroideae (1856-1857) 24 \& Prodr. Syst. Aroid. (1860) 572; Engl. in A. \& C. DC., Monogr. Phan. 2 (1879) 89-90 \& Bull. Soc. Tosc. Ortic. 4 (1879) 267 \& in Becc., Malesia 1 (1882) 263 \& Bot. Jahrb. Syst. 25 (1898) 4; K. Schum. \& Lauterb., Fl. Schutzgeb. Südsee (1901) 210; Engl. in Engl. Pflanzenr. 21 (IV.23B) (1905) 38-39, Fig.16; Engl. \& K. Krause, Nova Guinea 8 (1910) 247; Merr., Enum. Philippine Pl. 1 (1922) 173; Elmer, Leafl. Philippine Bot. 10(133) (1938) 3628; Hay in Johns \& Hay, Stud. Guide Monocot. Papua New Guinea 1 (1981) 
fig.28; Peekel ex Henty, Fl. Bismarck Archip. (1984) 66, fig.108; Hay, Aroids of Papua New Guinea (1990) fig.33; Hay, Blumea 40 (1995) 402-404. - Scindapsus rumphii (Schott) C. Presl, Epimel. Bot. (1851) 242. - Type: Adpendix porcellanica Rumph., Herb. Amboin. 5 (1747) t.182, fig.1.

Pothos rumphii Schott var. giganteus Engl. Bot. Jahrb. Syst. 25 (1898) 4; K. Schum. \& Lauterb., Fl. Schutzgeb. Südsee (1901) 210; Engl. in Engl., Pflanzenr. 21 (IV.23B) (1905) 38-39; Engl. \& K. Krause, Nova Guinea 8 (1910) 247. - Type: Papua New Guinea, Madang Prov., Gogol River, Lauterbach 932 (SING, lecto, selected by Hay (1995)).

[Pothos insignis auctt. non Engl. Bull. Soc. Tosc. Ortic. 4 (1879) 267: Engl. in K. Schum. \& Hollrung, Fl. Kais. Wilh. Land (1889) 19 \& in K. Schum., Notizbl. Königl. Bot. Gart. \& Mus. Berl.-Dahlem 2 (1898) 99; Warb., Bot. Jahrb. Syst. 13 (1891) 267.].

Very robust and vigorous, sometimes smothering, moderately ramified homeophyllous root-climbing liane reaching into the crowns of canopy trees. Shoot system rather poorly differentiated into adherent and flowering branches; stem of mature sterile shoot to $2 \mathrm{~cm}$ diam., internodes up to $35 \mathrm{~cm}$ long, terete in cross-section; stem of juvenile shoot to $4 \mathrm{~mm}$ diam., terete in cross-section with the leaves slightly congested to scattered, the petioles weakly ascending, and the blades pendulous; eocaul foraging and climbing, often very long. Leaves rich green, glossy above, stiffly chartaceous, drying pale grey-yellowish green; petiole 9-16.5 $\times 0.3-1.2 \mathrm{~cm}$, stout, sheath prominent, reaching to the base of apical geniculum; blade 15-50 $\times 5-19 \mathrm{~cm}$, pendulous, elliptic to ovate-oblong, tip somewhat acuminate to obtuse, ultimately with a flexuous filiform mucro, base acute; primary lateral venation diverging at $\mathrm{c}$. $60-80^{\circ}$, crossed by usually three intramarginal veins on each side of the midrib, these arising from near the base of the midrib and running more or less to the leaf tip. Inflorescence solitary at the end of leafy, pendulous shoots; peduncle 10-20 $\times 0.2-0.5 \mathrm{~cm}$, about equaling the petiole of the subtending leaf, most of it within the sheath at flowering, but extending up to twice original length in fruiting specimens. Spathe 11-27 $\times 1-5 \mathrm{~cm}$, somewhat exceeding the spadix, narrowly lanceolate, distally somewhat twisted, membranous, green. Spadix conspicuously stipitate; stipe $2-4 \times$ $0.15-0.25 \mathrm{~cm}$; fertile portion $10-22 \times 0.35-0.8 \mathrm{~cm}$, long-cylindrical, brownish green at flowering. Flowers c. $2.5 \mathrm{~mm}$ diam. with (4)-6 free to fused tepals and (4)-6 stamens. Infructescence considerably elongated, to $40 \mathrm{~cm}$ long, pendulous, often twisted, with very many berries; fruit to c. $2.5 \times 1.5 \mathrm{~cm}$, ovoid, scarlet when ripe; seeds c. $3 \times 6 \mathrm{~mm}$ ellipsoid. - Fig. 14, 15.

Distribution - Solomon Islands and Vanuatu. In Malesia: Sulawesi, Maluku, New Guinea. One of us (A.H.) observed this species in Vanuatu in 1989, but we are not aware of any herbarium material.

Although very widespread and common east of Wallacea, this species is not found in Australia. In the Philippines it is replaced by P. dolichophyllus and P. ovatifolius, and in Borneo and further west by P. ovatifolius.

Habitat - In a wide range of situations, most commonly in lowland rainforest and regrowth but also found in upper hill forest and in sago palm swamp, and on limestone, sea-level to $1000 \mathrm{~m}$ altitude. In New Guinea it is very common in the lowlands, especially in disturbed forests, often almost completely covering trees and hanging to the ground.

Notes - Pothos tener is based on figure 2 of Rumphius' plate of Adpendix arborum, a depiction of a Moluccan plant. It is evidently a somewhat depauperate form of, but otherwise compatible with the plant hitherto more widely known as Pothos rumphii, as the illustration matches no other known Moluccan Pothos. 


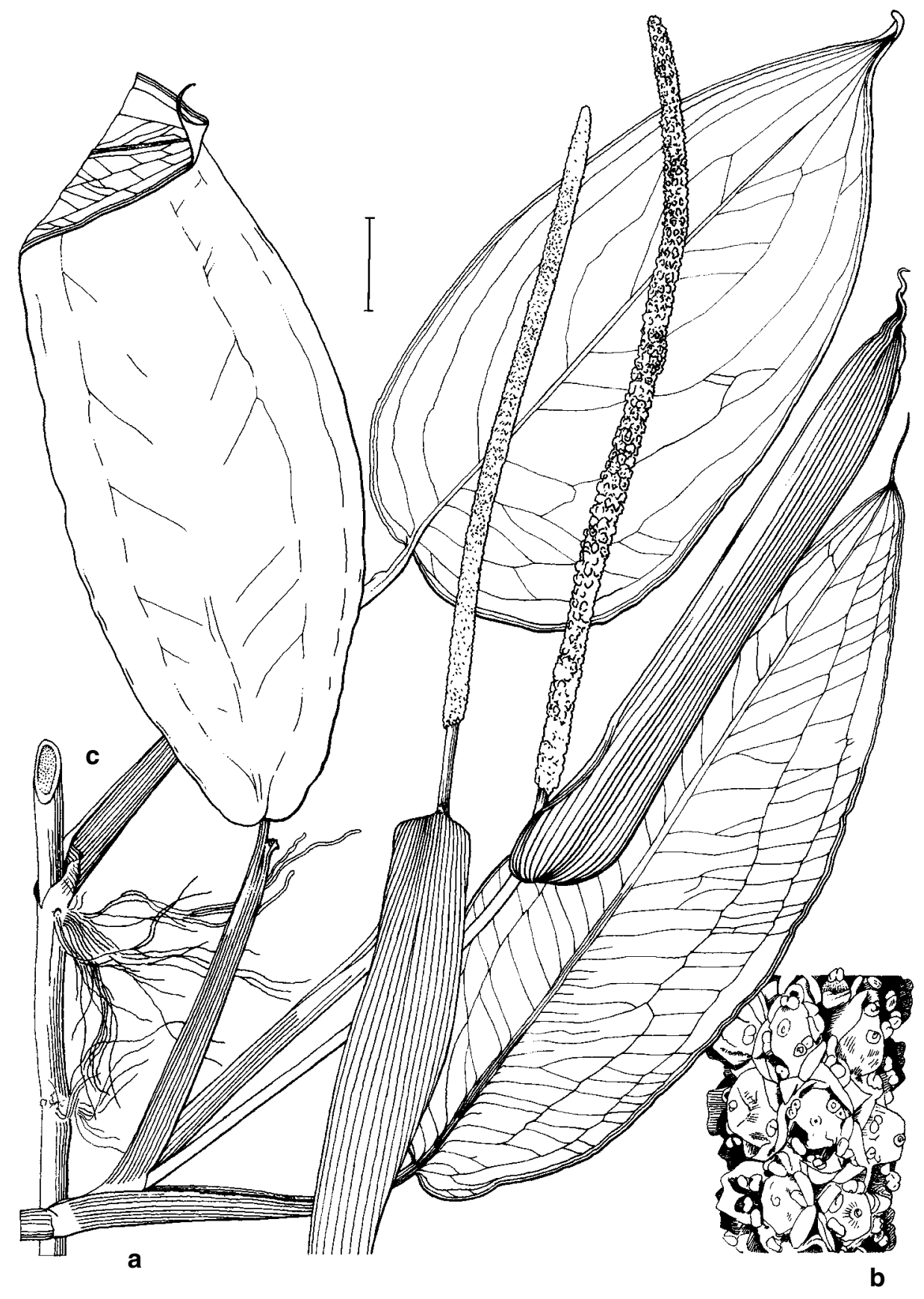

Fig. 14. Pothos tener. $\mathbf{a}$, fertile shoot in flower and early fruit; $\mathbf{b}$, flowering spadix detail; $\mathbf{c}$, adult adherent shoot: a, b, Burley et al. 3569; c, Nicolson 1566. Scale bar: a, c = 2 cm; b = $3.2 \mathrm{~mm}$. 


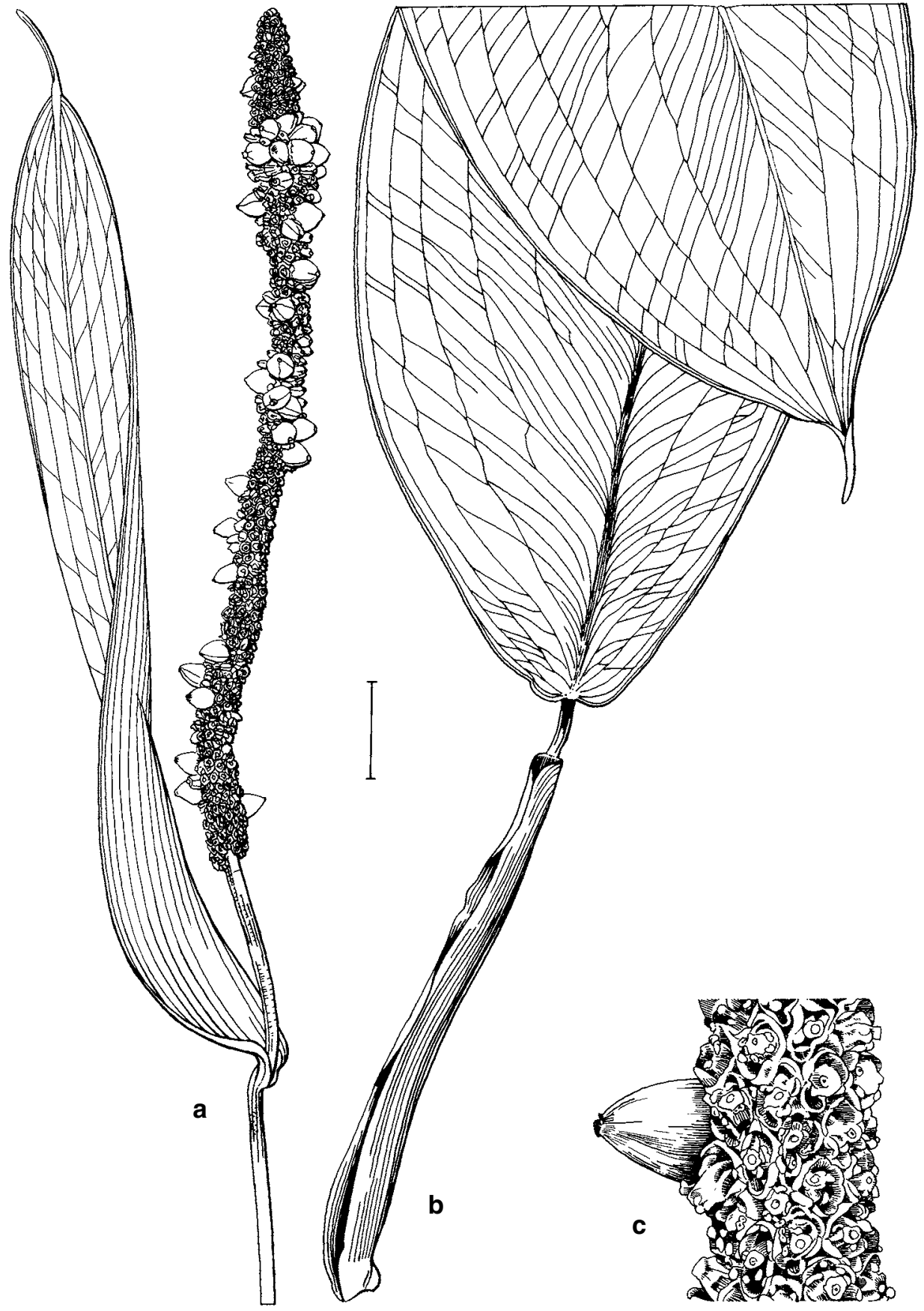

Fig. 15. Pothos tener. a, infructescence; $\mathbf{b}$, fruiting spadix detail; $\mathbf{c}$, leaf: a-b, Johns $7676 ; \mathrm{c}$, Dransfield et al. 7562 . Scale bar: $\mathrm{a}, \mathrm{c}=2 \mathrm{~cm} ; \mathrm{b}=5 \mathrm{~mm}$. 
Evidently very closely related to $P$. dolichophyllus and P. ovatifolius (both Sundaic and absent from Wallacea/Sahul), P. tener is readily separable from the former by the longstipitate spadix and from the latter by the more thinly textured oblong leaf blade.

Other specimens examined: SULAWESI: Minahassa, Kelelonde, Soputan Mts, Alston 15831 (BM); Menado, Palu, Bloembergen 4032 (BO); No further information, Brook 16876 (BM); N Sulawesi, c. 220 $\mathrm{km} \mathrm{W}$ of Menado, km 50 inland from Pangi on Sg. Ilanga, Burley et al. 3569 (A); N Sulawesi, 250 $\mathrm{km} \mathrm{W}$ of Gorontalo, 7k km inland from Papayuto, tributary of Sg. Papayuto, Burley et al. 4136 (A, BO, K); C Sulawesi, Donggala, Pangi-Binangga N.R., Puncak Beringin Study Area, Bynum 7500 (A, K); Kabon Kopi, Curran 3448 (A, US); Kabupaten Kotamobago, G. Ambang, near Poopo, de Vogel 2631 (A, BO, L, US); C Sulawesi, Sopu valley, c. $80 \mathrm{~km} \mathrm{SSE} \mathrm{of} \mathrm{Palu,} \mathrm{de} \mathrm{Vogel} 5061$ (BO, K, L), de Vogel 5087 (BO, K, L); Sulawesi Utara, Bolaang Mongondow, Dumoga Bone N.P., Toraut Dam, Toraut River, de Vogel \& Vermeulen 6461 (BO, L); de Vogel \& Vermeulen 6660 (BO, L, US); Membulu, Elbert 3787 (BO); Minahassa, Kolonedale, camp 2, Tompantette, Eyma 3986 (BO); Minahassa, N slope of G. Klabat, Forman 240 (K); C Sulawesi, Ds Tonosu, Kec. Pamona Utara. Kab. Poso, Hamzah 6 (BO); Liasa, Kjellberg 2274 (BO); Minahassa, Runokelung, Koorders 16151 (BO); Minahassa, Koorders 16158 (BO); Minahassa, Koorders 16177 (BO); Minahassa, Koorders 16178B (K, P); Minahassa, Lam 2427 (BO); Kanakelang, Pasir Malago (?), Labo, Lam 3012 (BO); Between Palu and Parigi, 35 km from Palu, Meijer 9368 (BO, US); Between Palu and Parigi, $35 \mathrm{~km}$ from Palu, Meijer 9410 (US); Area of Mt Nokilalaki, above Toro, Meijer 9463 (BO); Tompokbalang, Maros, Soenarko 316 (BO, K); C Sulawesi, Sopu valley, c. 80 km SSE of Palu, van Balgooy 3051 (BO, K, L); P. Butang (Buton), Mata area, Wakunti F.R., Baubau, Widjaja 603 (BO). MALUKU: Halmahera, Backer 1875 (BO), Sula, Sula Sanana, Bloembergen 4501 (SING); Ambon, G. Harul, Boerlage 86 (BO); P. Tenimber, P. Jamdena, near resthouse between Kp. Ilgnei and Otimmer, Buwalda 4126 (A, BO, K); Halmahera, G. Sahu, near Susupu, de Vogel 3321 (BO, K, L, MO); Halmahera, Weidamo, Idjan \& Mochtur 195 (BO); Halmahera, Teluga rano, Idjan $\mathcal{E}$ Mochtur 265 (A, BO, K); W Ceram, Kairatu, Gemba, Kuswata E Soepadmo 37 (BO, K); P. Buru, W Buru, Bara, Wae Duna, Base Camp 7, Mogea 5367 (BO, K, L); 'Maluku', Puruwansingsiti \& Sanusi 30 (BO); Amboin, Paso, Robinson 116 (K, P, US), Robinson 117 (US); Halmahera, Wasile, Kg Loleba, Taylor 2164 (US); Ambon, Teysmann s.n. (BO); Buru, Leksula, Toxopeus 623 (BO). NEW GUINEA: PAPUA BARAT: Cenderawasih Prov., Wandammen Peninsula, Wondiwoi Mts, BW 13309 (L, LAE); Kepala Burung Prov., Sorong, Djamhari 470 (A, BRI, K, L, SING); Kepala Burung, Manokwari, Nuni, Sg. Asai, J. Dransfield et al. 7562 (BO, K, MAN); Kepala Burung Prov., on road from Manokwari past Pasir Puthi to N coast road, Johns 7676 (BO, K, MAN); Kepala Burung, Manokwari Prov., Arfak plains, approaching logging area c. $1 \mathrm{~km}$ E of Wariori River, Johns 8142 (BO, K, MAN); Biak Is., hill NE of Mokmer airport, Nicolson 1566 (B, K, L, LAE, P, US); Fanindi, $1 \mathrm{~km} \mathrm{~W}$ of Manokwari, Nicolson 1572 (B, K, L, LAE, P, US); Kepala Burung, Manokwari, Arfak plains, close to road from SP7 to Sg. Wariori, Sands 6270 (BO, K, MAN); Mimika Prov., Freeport Concession Area, Rimba Irian Golf Course, outskirts of Kuala Kencena, Utteridge 108 (BO, K, MAN); Mimika Prov., Freeport Concession Area, Utteridge 391 (BO, K, MAN). PAPUA NEW GUINEA: Central Prov., Kokoda, Carr 16162 (B, BM, K, L, SING); Central Prov., Veiya, Carr 11729 (BM, K, L, LAE, SING); E Sepik, Along small River S of Boys Town (reform school operated by S.V.D. missionaries), Croat 52781B (MO); Morobe, Lae B.G., Croat 52848 (MO); New Ireland, Lamet, NW Lavongai, $5 \mathrm{~km}$ S of Lai Bay, Croft \& Lelean LAE 65463 (A, BRI, CANB, E, K, L, LAE, US); E Sepik, Aitape, near Sumo on Rhainbrum River, Darbyshire $\mathcal{E}$ Hoogland 8077 (BM, CANB, L, LAE); Bougainville, Buin, 1 mile N of Tonolei harbour, Foreman NGF 45669 (LAE, US); Manus, Derimbat, Foreman NGF 52349 (LAE, US); Milne Bay Prov., near Kaibola, Frodin UPNG 977 (K, L, LAE, UPNG); Bougainville, Kieta, Kajewski 1607 (P); Bougainville, Buin, Kugi-maru, Kajewski 1813 (P); Milne Bay, Rabaraba, Ma-u River, Katik NGF 56290 (LAE, US); Mussau, Malakata, Koie \& Ølsen 1686 (C); Bougainville, Pavairi, Lavarack \& Ridsdale NGF 31188 (BRI, K, L, LAE, US); Mile Bay, Normanby Island, Eaa'ala, Sewa Bay, Lelean \& Streimann NGF 52542 (L, LAE, US); Admiralty Islands, Moseley s.n. (K); Central Prov., Brown River F.R., 20-25 miles NW of Port Moresby, Nicolson 1424 (US); Central Prov., Sogeri Plateau, between Subitana and Javereri, headwaters of Kemp Welsh River, Nicolson 1447 (B, K, L, US); New Britain, Kareeba road, 2 miles E of Kerevat, Nicolson 1497 (B, K, L, LAE, US); Bougainville, Arawa, McKillup's Arawa Plantation, 6 miles W of Kieta, Nicolson 1523 (K, US); New Britain Is., 3 miles NE of Kandrian, Nicolson 1548 (US); E Sepik Prov., Ambunti, Waskuk Hills, area around Langu and Garuka, ridge towards Waskuk Hills, Regalado \& Takeuchi 1502 (K); W Sepik Prov., Amanab, Bewani Mts, near Kilifas on Yenabu River, not far from Imonda petrol track, Sands 1169 (K); Manus, E Manus, Mundrau, depression S of Kari, c. 8.5 km inland from N coast, below Ndrias karst, Sands et al. 2687 (K); Manus, 
W Manus, $1 \mathrm{~km} \mathrm{SW}$ of Kabuli, on S coast, Sands et al. 2778 (K, US); Bougainville, vicinity of Aku, c. 10 miles W of Buin Station, Schodde E Craven 4042 (A, CANB, K, L, LAE); Manus, SW Manus, Kabuli, Stone 10387 sub. LAE 53687 (A, BRI, K, L, LAE, US); New Britain, Cape Hoskins, Mosa Forestry Plantation, Streimann NGF 44401 (K, L, LAE, US); W Sepik, Vanimo, Wutung, Streimann NGF 52784 (LAE, US); W Sepik Prov., Vanimo, Ossima, Streimann \& Kairo NGF 39265 (CANB, K, L, LAE, US); Morobe Prov., Herzog Mountains, Gabensus logging track, Takeuchi 7386 (K); Bougainville, Siwai, Waterhouse 196C-B (K); Bougainville, Siwai, Waterhouse 432-B (K); 'Kaiser Wilhelmsland', Weinland 284 (K). SOLOMON ISLANDS: Small Malaita, N of Tarapaina, Gafui et al. BSIP 16967 (BSIP, K, L, LAE); Choiseul, Dalepima area, Mbirambira, Gafui et al. BSIP 18828 (BSIP, L, LAE, SING, US); Kolombangara, 2 miles NNW of Kuzi, Hunt 2400 (BSIP, K, US); Vella Lavella, S Vella Lavella, Oual River area, Kotali et al. BSIP 11187 (BSIP, K, L, LAE, SING); Kolombangara, Shoulder Hill area, Mauriasi et al. BSIP 8727 (BSIP, K, L, LAE, SING), Mauriasi et al. BSIP 11396 (BSIP, K, L, LAE)l Northern Treasury Is., Kughala River area, Mauriasi et al. BSIP 14064 (BSIP, K, SING); Ranongga, Kolomali area, Mauriasi et al. BSIP 14313 (BSIP, K, L, LAE, SING, US); Ranongga, SE Ranongga, dam area, Mauriasi et al. BSIP 14391, (BSIP, K, L, LAE, SING); Ranongga, Palaina, Mauriasi et al. BSIP 15666 (BSIP, K, L, LAE, SING); Ranongga, SE Ranongga, Mauriasi et al. BSIP 15764 (BSIP, K, L, LAE, US); Guadalcanal, Tina/Toni River area, Nakisi \& Babala BSIP 8244 (BSIP, K, SING); Kolombangara, Poitete F.R., along access trail to Mt Veve, Regalado \& Sirikolo 730 (K, MO); Shortland Is., SW Koang Kopi River, Runikera et al. BSIP 13073 (BSIP, K, L, LAE, SING); Choiseul, 3 miles inland from Liulu on N coast, Whitmore BSIP 3910 (BSIP, K, LAE, SING).

\section{Pothos dolichophyllus Merr.}

Pothos dolichophyllus Merr., Philipp. J. Sci.., Bot. 11 (1916) 4. — Pothos rumphii Schott var. dolichophyllus (Merr.) Nicolson, Amer. J. Bot. 54 (1967) 496. - Type: Philippines, Luzon, Sorsogon Prov., Jul-Aug 1915, Ramos BS 23708 (PNH, presumed destroyed, holo; iso P, US).

Pothos acuminatissimus Merr., Philipp. J. Sci., Bot. 11 (1916) 175 \& Enum. Philippine Pl. 1 (1922) 172, syn. nov. - Type: Philippines, Samar, Catubig River at Tagabiran, 10 Feb 1916, Ramos BS 24125 (PNH, presumed destroyed, holo; iso US).

Robust and vigorous, moderately ramified homeophyllous root-climbing liane to at least $5 \mathrm{~m}$, but frequently greatly exceeding this. Shoot system rather poorly differentiated into adherent and flowering branches; eocaul and seedling not observed. Leaves stiffly thinly-chartaceous, drying pale yellowish green; petiole 8-30 $\times$ 0.4-1 cm, slender to very stout, sheath prominent, extending to base of apical geniculum; blade $14-50 \times 5.5-19 \mathrm{~cm}, \pm$ pendulous, elliptic to oblong elliptic, rarely linear-elliptic, apex acuminate to obtuse, with a flexuous filiform mucro, base acute to rounded; primary lateral venation diverging at c. $60-80^{\circ}$, crossed by usually three intramarginal veins on each side of the midrib, these arising from near the base of the midrib and running more or less to the leaf tip. Inflorescence solitary or a few together at the end of leafy, pendulous shoots; peduncle $16-25 \times 0.4-1 \mathrm{~cm}$, about equalling the petiole of the subtending leaf, extending by up to double in fruiting specimens. Spathe $13-27 \times 2.5-5 \mathrm{~cm}$, somewhat exceeding the spadix, narrowly lanceolate, distally somewhat twisted, membranous, green. Spadix sessile, $10-19 \times 0.7-1.5 \mathrm{~cm}$, slender to stout cylindrical, yellow at anthesis. Flowers $2-2.5 \mathrm{~mm}$ diam. with (4)-6, free tepals and (4)-6 stamens. Infructescence considerably elongated, to c. $30 \mathrm{~cm}$ long, pendulous, with many berries; fruit to c. $2.5 \times 1.5 \mathrm{~cm}$, ovoid, scarlet when ripe; seeds not observed. - Fig. 16.

Distribution - Malesia: endemic to and widespread in the Philippines.

Habitat - Primary to secondary dipterocarp forest in valleys, on slopes and ridges, 110-900 m altitude.

Notes - Evidently very closely related to P. tener (which is absent from Sunda) but readily separable by the consistently sessile spadix and geographical disjunction. Confusion with $P$. ovatifolius is possible, although the latter has a stipitate spadix. 


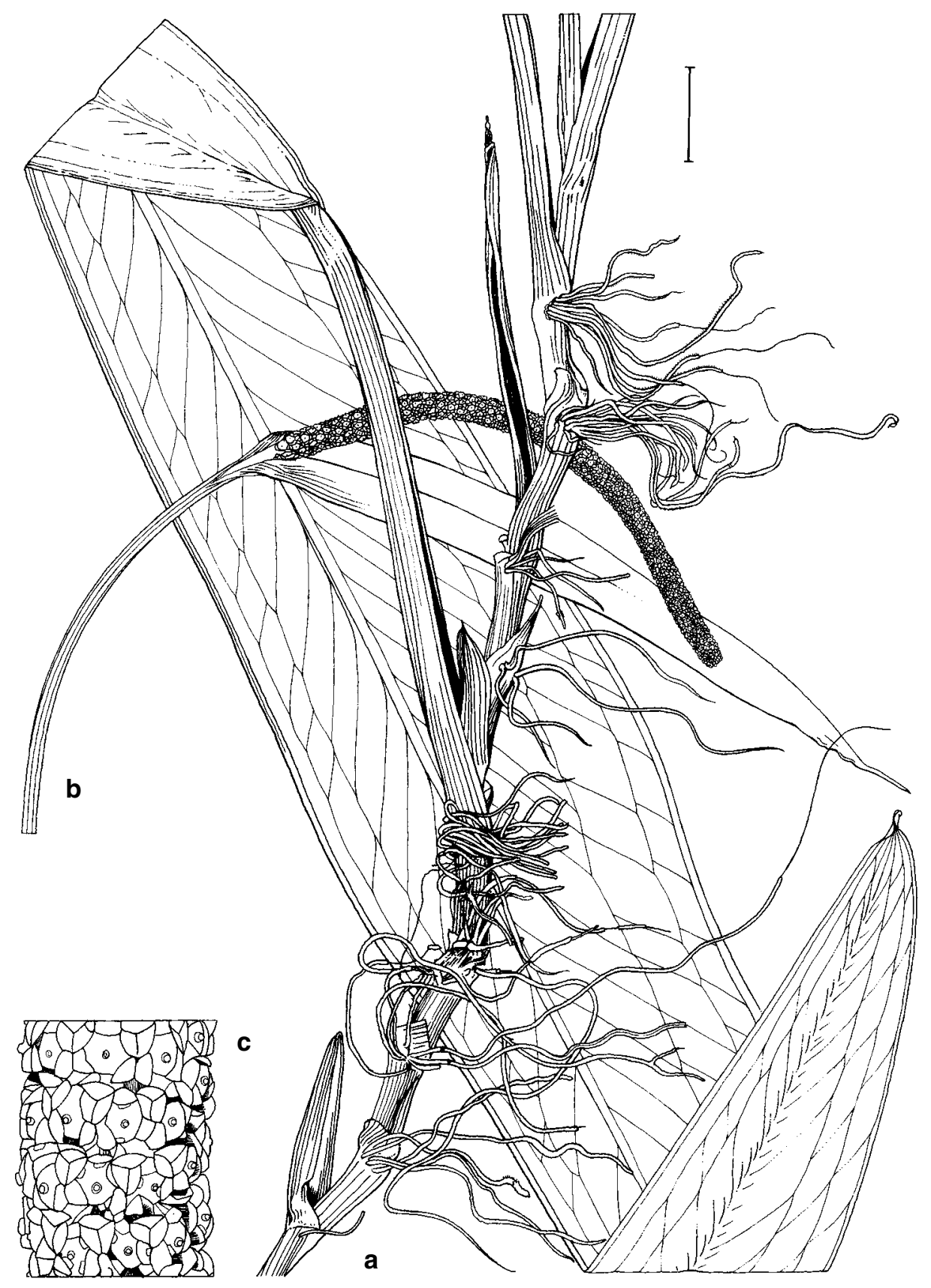

Fig. 16. Pothos dolichophyllus. a, adult adherent shoot; b, inflorescence; $\mathbf{c}$, spadix detail: a, Ramos BS 23708; b \& c, Nicolson 777. Scale bar: a, b, $=2 \mathrm{~cm}$; c $=3.5 \mathrm{~mm}$. 
Pothos acuminatissimus is simply a form of $P$. dolichophyllus with narrower leaf blades than typical for the species.

Other specimens examined: PHILIPPINES: Luzon, Camarines Sur, Naga City, Mt Isarog, Barbon et al. PPI 8141 (US); Luzon, Quezon N.P., Croat 53005 (MO); Luzon, Tayabas, Curran FB 9656 (US); Samar, Mt Purog, Edaño PNH 15426 (PNH); Luzon, Sorsogon Prov., Mt Juban, Edaño PNH 37152 (PNH); Luzon, Tayabas Prov., Lucban, Elmer 9268a (BM, E, K, MO, US); Luzon, Sorsogon Prov., Irosin (Mt Bulusan), Elmer 15854 (A, C, K, MO, P, US); No further information, Loher 7033 (K); Luzon, Laguna, Banahao, Loher 7052 (K); Luzon, Albay Prov., Mayon volcano, Mendoza PNH 18238 (PNH); Mindanao, Surigao, Sukailang, Mendoza \& Convocar PNH 10237 (A); Palawan, Taytay, Merrill BS 9761 (P, US); Mindanao, Davao Prov., Compostela, Maparat Barrio, 70 km NE of Davao, Nicolson 699 (PNH, US); Luzon, Sorsogon, Mt Bulusan, S side, near Lake Bulusan, Nicolson 758 (US); Luzon, Sorsogon, Mt Bulusan, pathside around Lake Bulusan, Nicolson 776 (US), Nicolson 777 (US), Nicolson 778 (US); Luzon, Sorsogon, Mt Bulusan, above Lake Bulusan, Nicolson 782 (US); Samar, Loquilocan Barrio, $10 \mathrm{~km} \mathrm{~W}$ of Wright, Nicolson 804 (PNH, US); Leyte, near lumber camp above Putok River, Nicolson 821 (US); Mindanao, Camaguin de Mindanao, Ramos BS 14707 (BM, K, US); Luzon, Sagnay, Camarines, Ramos BS 22132 (P, US); Samar, Catubig River, Ramos BS 24144 (US); Luzon, Sorsogon Prov., Lake Bulusan, Sinclair \& Edaño 9616 (E, K, PNH, SING, US); Mindanao, Butuan, Weber 1044 (A, US); Leyte, Wenzel 22 (BM, MO, US); Mindanao, Lanao Prov., vicinity of Olangu, near Momungan, Zwickey 835 (A).

\section{Pothos ovatifolius Engl.}

Pothos ovatifolius Engl. in Engl., Pflanzenr. 21 (IV.23B) (1905) 40; Elmer, Leafl. Philippine Bot., 10(133) (1938) 3628; Merr., Enum. Philippine Pl., 1 (1922) 173. - Type: Philippines, Luzon, Albay, Mar 1886, Vidal 3969 (K, holo).

Pothos merrillii K. Krause, Bot. Jahrb. Syst. 45 (1911) 657, syn. nov. - Type: Philippines, Siquijor, Sep 1910, Merrill BS 7211 (B, holo).

Pothos ovatifolius Engl. var. simalurensis Alderw., Bull. Jard. Bot. Buitenzorg III, 4 (1922) 337, syn. nov. - Type: Indonesia, Sumatera, Aceh, P. Simeulue (Simalur), Tapoe, Defajan, 12 Feb 1920, Achmad 1683 (BO, holo; iso BO).

Very robust, vigorous, moderately ramified semi-heterophyllous root-climbing liane to $30 \mathrm{~m}$. Shoot system weakly or not differentiated into non-flowering and flowering branches; eocaul foraging and climbing, often very long with occasional stretches of a few shingling leaves; seedling shingling. Leaves mid-green, semi-glossy above, stiffly chartaceous to coriaceous, drying pale grey-yellowish green; petiole $(1-) 5-16 \times 0.5-1.3 \mathrm{~cm}$, rather stout, sheath prominent, extending to just over the base of the apical geniculum, lower portion clasping stem; blade (3-)8.5-27 × (2.5-)7-27 cm, spreading, oblong ovate to very broadly ovate, oblique, sometimes profoundly so, apex acuminate to obtuse, ultimately with a stout tubular mucro, base broadly rounded to narrowly cordate; primary lateral venation diverging at c. $60-80^{\circ}$, crossed by usually three intramarginal veins on each side of the midrib, these arising from near the base of the midrib and running more or less to the leaf tip. Inflorescence solitary at the end of leafy, pendulous shoots; peduncle 9-15 cm, about equalling the petiole of the subtending leaf, most of it within the sheath at flowering. Spathe 14-23 $\times 3-5 \mathrm{~cm}$, somewhat exceeding the spadix, narrowly lanceolate to narrowly elliptic, distally somewhat twisted, membranous, green. Spadix conspicuously stipitate; stipe c. 2-4 $40.15-0.2 \mathrm{~cm}$; fertile portion 9-20 $\times 0.7-1.4 \mathrm{~cm}$, long-cylindrical, brownish yellow-green or purple. Flowers c. $2.5 \mathrm{~mm}$ diam.; with 6 free tepals and 6 stamens. Infructescence elongated, to c. $17 \mathrm{~cm}$ long, pendulous, with many berries; fruit $1.4-2.5 \times 1-1.5 \mathrm{~cm}$, ovoid, to scarlet when ripe; seeds c. $3.5 \times 5 \mathrm{~mm}$, ellipsoid, pale greenish brown. - Fig. 17 .

Distribution - Malesia: Sumatera (P. Simeulue), Malay Peninsula (P. Tioman), Borneo (Sarawak, Sabah), Philippines (widespread). 
Habitat - Primary to degraded secondary lowland to lower montane forest, $70-1400 \mathrm{~m}$ altitude.

Notes - Closely related to $P$. tener but readily separable by the much more coriaceous ovate, cordate-based leaf blade. Confusion with $P$. dolichophyllus is possible, although the latter has a sessile spadix and oblong leaf blade. Pothos dolichophyllus and $P$. ovatifolius occur sympatrically at Lake Bulusan, and probably elsewhere, in the Philippines. This species is not common in north Borneo, occurring as small scattered populations in wet River valleys in Sabah.

Pothos merrillii and P. ovatifolius var. simalurensis are uncontroversially synonymous with P. ovatifolius.

Other specimens examined: SUMATERA: Benkulu, P. Enggano, Lütjeharms 4457 (A, K, P), Lütjeharms 4759 (BO, K, P), Lütjeharms 4760 (A, BO, K, P). PENINSULAR MALAYSIA: Pahang, P. Tioman, Jawa Bay, Burkill s.n. (SING); Pahang, P. Tioman, Bk. Bt. Berendam Nur SING 21753 (K, SING). BORNEO: SARAWAK: Ben Kaian, Brooks s.n. (SING). SABAH: Tambunan Distr., road to Kg Tondulu, Kg Tondulu valley, Boyce 1422 (K, SAN, SP); Tambunan Distr., Kg Kangeran road, Bt. Lapan, 1.5 hours by car from Kg Kangeran, Boyce 1423 (K, SAN, SP). PHILIPPINES: Luzon, Camarines Sur, Covangcognon, Pili, Mt Isarog, Convocar PNH 2892 (A); Luzon, Quezon N.P., Croat 52982 (MO); Luzon, Sorsogon, Curran FB 12247 (US); Luzon, Camarines Norte, Mt Cadig, Edaño PNH 40154 (BM, K); Luzon, Sorsogon, Mt Juban, Edaño PNH 37200 (BM, K, PNH); Luzon, Tayabas, Lucban, Elmer 9243 (E, K, MO, US); Negros, Negros Oriental, Dumaguete (Cuernos Mts), Elmer 9618 (BM, BO, E, K, MO, US); Mindanao, Agusan, Cabadbaran (Mt Urdaneta), Elmer 14014 (A, E, BO, MO, US); Luzon, Sorsogon, Irosin (Mt Bulusan), Elmer 15204 (A, BM, BO, C, K, MO, P, US); Mindanao, Davao, Hijo, Odell Plantation, Gachalian PNH 33692 (L, PNH); Mindanao, So. Cotabato, Koronadal, Taplan/Lamsoal, Miasong, Tupi, Gaerlan et al. PPI 5443 (US); Mindanao, Tungao, San Mateo, Butuan Ojot River, km 22, Mendoza PNH 42452 (PNH, US); Luzon, Sorsogon, Mt Bulusan, SE side, along path around Lake Bulusan, Nicolson 762 (B, K, US); Samar, Loquilocan Barrio, Nicolson 806 (PNH, US); Leyte, near lumber camp above Putok Barrio, c. $22 \mathrm{~km}$ SW of Tacloban, Nicolson 819 (K, US); Palawan, Balabac, Dalawan Bay, Ølsen 540 (C); Palawan, Penigisan, Ølsen 359 (C); Luzon, Tayabas, Mt Pular, Ramos BS 19367 (US); Samar, Catubig River, Ramos BS 24543 (US); Luzon, Tayabas, Mt Binuang, Ramos \& Edaño BS 28549 (BO, P, US); Leyte, Cabalian, Ramos BS 41549 (BO, P, SING, US); Bohol, Ramos BS 42820 (BO, K, P); Catanduanes, Sorsogon Prov., Mt Juban, Ramos E Edaño PNH 75424 (SING); Palawan, Taytay, Lake Manguao (Danay), valley stream leading into NNW bay of lake, Ridsdale SMHI 362 (BO); Basilan, Lamitan, Basilan City, Bureau of Animal Husbandry Breeding Station, E side of Banis Malsony, Santos 4154 (US); Luzon, Quezon N.P., 25 km E of Lucena, Soejarto et al. 7823 (A, MO); Luzon, Sorsogon, Mt Bulusan, along road to Bulusan Lake, vicinity of crossing, Sulit PNH 2623 (PNH); Mindanao, Lanao, vicinity of Dansalan-Ramain road, Zwickey 171 (A); Mindanao, Lanao, vicinity of Olangu, near Momungan, Zwickey 714 (A).

\section{Pothos leptostachyus Schott}

Pothos leptostachyus Schott, Prodr. Syst. Aroid. (1860) 571; Engl. in A. \& C. DC, Monogr. Phan. 2 (1879) 91 \& in Engl., Pflanzenr. 21 (IV.23B) (1905) 41; Ridl., J. Straits Branch Roy. Asiat. Soc. 44 (1905) 187. - Type: Indonesia, S Kalimantan, Bangarmassin, Motley 1197 (K, holo).

Pothos lorispathus Ridl., J. Straits Branch Roy. Asiat. Soc. 86 (1922) 310 ('lorispatha'); Ridl., Fl. Malay Penins. 5 (1925) 130; Boyce, Blumea 45 (2000) 195-198, fig.13a,13b, syn. nov. - Type: Malaysia, Selangor, Batu Caves, Ridley s.n. (SING, holo; iso K).

Slender to rather robust, (heterophyllous?), root-climbing liane to $8 \mathrm{~m}$. Stem?; eocaul \& seedling not observed. Leaves mid-green adaxially, slightly paler abaxially, stiffly but thinly chartaceous, drying dull greenish; petiole $3-7 \mathrm{~cm}$ long, slender, sheath somewhat prominent, extending to just below geniculum, basally clasping, apically briefly auriculate to slightly ligulate; blade $10-34 \times 2.5-10 \mathrm{~cm}$, oblong-elliptic, often falcate, unequal, occasionally quite strongly so, base rounded, apex acute to acuminate, very briefly apiculate; intramarginal veins 2 per side, the lowermost 

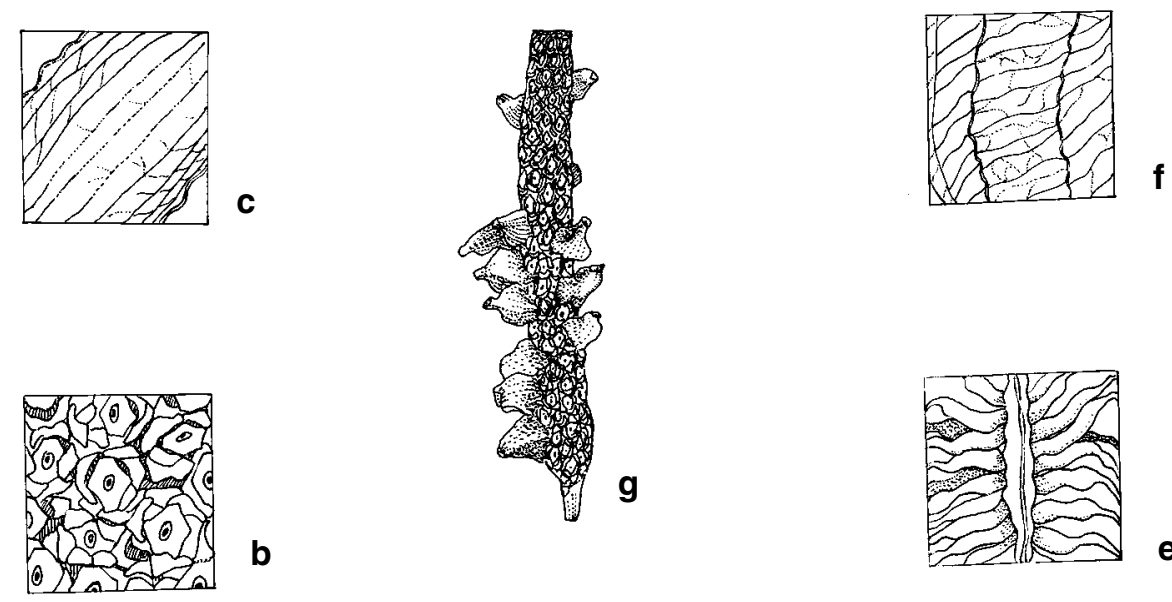

b
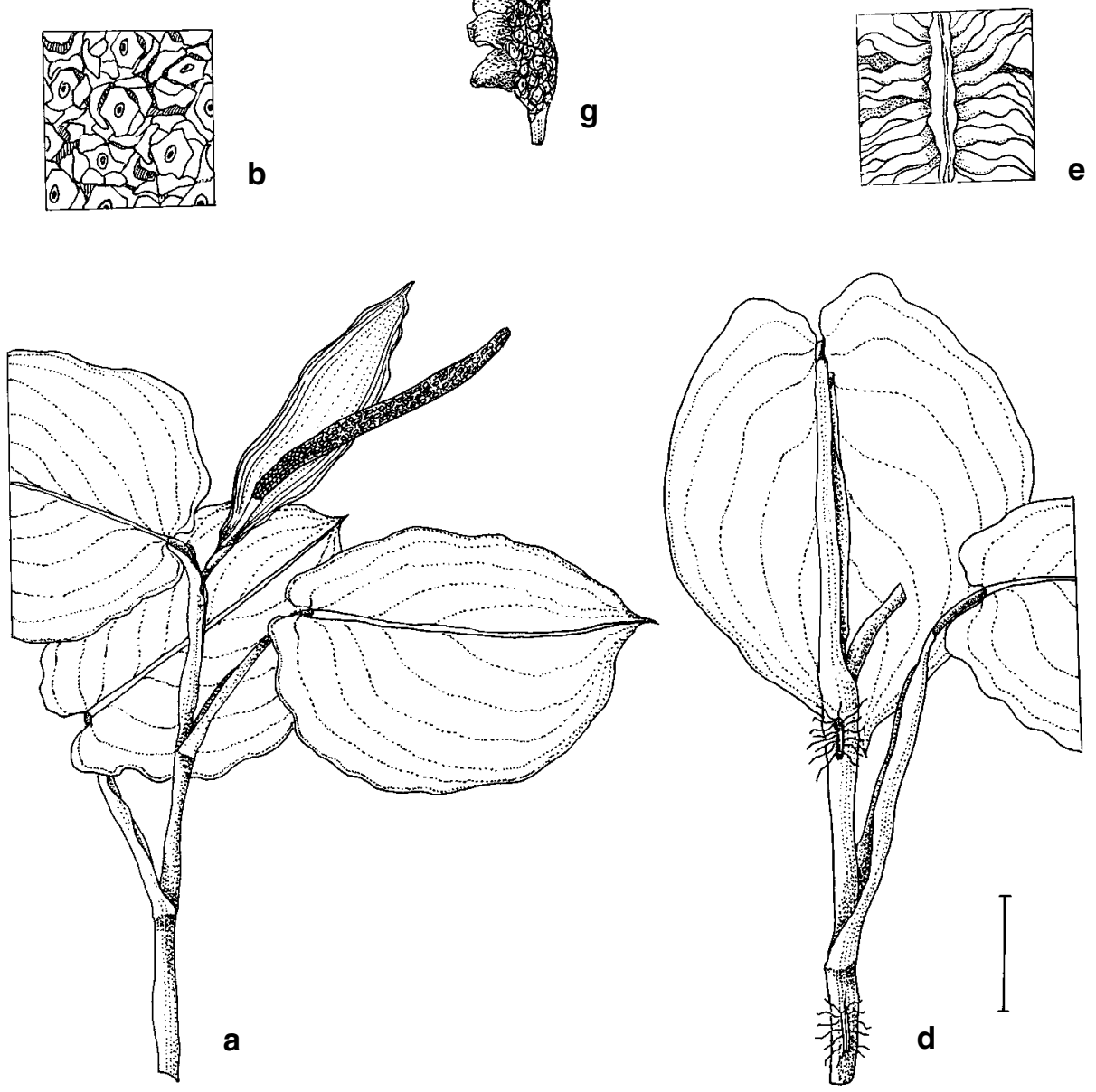

Fig. 17. Pothos ovatifolius. a, flowering shoot; $\mathbf{b}$, spadix detail; $\mathbf{c}$, spathe venation detail; $\mathbf{d}$, adult adherent sterile shoot; $\mathbf{e}$, detail of mid-vein; $\mathbf{f}$, venation detail; $\mathbf{g}$, mature infructescence detail: a-c, Nicolson 762; d-f, Elmer 9618; g, Edaño PNH 37200. Scale bar: c, f, g, $=2 \mathrm{~cm}$; a, d = $4.5 \mathrm{~cm}$; $\mathrm{e}=7 \mathrm{~mm} ; \mathrm{b}=5 \mathrm{~mm}$. 
arising from the base, the next arising from the lowest part of the midrib, outer intramarginal vein remaining very close and parallel to margin, inner vein c. $1 \mathrm{~cm}$ distant, both reaching the leaf tip; flowering shoot abbreviated, usually leafless but with 1-several well-developed cataphylls, very occasionally with one or more fully developed but reduced leaves, arising from below the leaf axils of fertile shoots. Inflorescence solitary from tips of leafy shoots, rarely terminal on (foliage-)leafless reiterative shoots arising in leaf axils or from leafless stems and then often with inflorescences at different stages of maturity; peduncle $2.7-5 \times 0.2-0.3 \mathrm{~cm}$, moderately stout, erect or curving and ultimately ascending and the inflorescence held erect, dull green. Spathe $2.5-10 \times 0.5-1.5 \mathrm{~cm}$, lorate, spreading, base auriculate, auricle margins inrolled, barely decurrent on the peduncle, apex obtuse, acuminate, mid-green. Spadix stipitate; stipe $0.8-1.5 \times$ c. $0.2 \mathrm{~cm}$, slender, terete, lime green; fertile portion 5-6.5 $\times$ $0.3-0.4 \mathrm{~cm}$, cylindrical to tapering slender-cylindrical, straight to slightly curved, base unequal, slightly cochleate, creamy-yellow. Flowers c. $1.5 \mathrm{~mm}$ diam.; tepals 6, free; stamens 6. Infructescence with numerous berries; fruit 10-15 $\times 5-8 \mathrm{~mm}$, obclavate to ellipsoid, ripening deep scarlet. Seeds c. 4-6×2-4 mm, ellipsoid. - Fig. 18, 19.

Distribution - Thailand (Yala). In Malesia: Sumatera (Aceh), Peninsular Malaysia (Pahang), Borneo (widespread).

Habitat - Damp to rather dry evergreen hill forest on limestone, 50-300 m altitude.

Note - Although sterile specimens are very difficult to identify, fertile specimens are instantly recognizable by the form and size of the inflorescences. Pothos leptostachyus is superficially similar to $P$. lancifolius but readily distinguishable by the lorate spathe, stipitate spadix and slender (not thickened) peduncle. It is also confusable with $P$. wallichii (also with long, slender peduncle and lorate spathe), but is distinguished by the erect, stouter inflorescences.

Other specimens examined: SUMATERA: Aceh, Lau Simerah and Lau Penangganjan, near Kutatjane, Alston 14510 (K, L); Aceh, G. Leuser N.R., Ketambe, valley of Lau Alas, near tributary of Lau Ketambe, c. $35 \mathrm{~km}$ NW of Kutatjane, de Wilde \& de Wilde-Duyfjes 12315 (K, L). PENINSULAR MALAYSIA: Pahang, Kuantan, Pancing, Bk. Cheras, Zainundin 1295 (UKMB). BORNEO: SARAWAK: 1st Div., Matang, Ridley s.n. (K); 1st Div., Matang Reservoir. Ridley s.n. (K). SABAH: Sandakan, Gomantong Caves, Kokawa \& Hotta 572 (K, KYO); Keningau, Ulu Sg. Karamatoi, Krispinus SAN 121908 (SAN); Tawau Hills Park, Bombalai Hill, Madani E Sigin SAN 111552 (K, SAN); Tawau, Tawau Hills Park, Bombalai Hill, Madani \& Sigin SAN 111552 (K, SAN); Tenom, Hutan Simpan Mendalom, Mantor SAN 136116 (SAN); Sandakan, Gomantong F.R., Dulong Lambu limestone massif, Gomantong limestone hill, S.P. Lim et al. 576 (NSW, SAN); Bk. Garam, Sg. PSN, Block 13, S.P. Soon SAN 131673 (K, SAN). KALIMANTAN: CE Kalimantan, W Koetai no.9 near G. Antjaloeng, Endert 2058 (A, BO, K); CE Kalimantan, W Koetai, Endert 2362 (BO).

\section{Pothos barberianus Schott}

Pothos barberianus Schott, Aroideae (1856-1857) 24, t.53 \& Prodr. Syst. Aroid. (1860) 573; Engl. in A. \& C. DC, Monogr. Phan. 2 (1879) 90; Hook.f., Fl. Brit. Ind. 6 (1893) 553; Engl. in Engl., Pflanzenr. 21 (IV.23B) (1905) 40; Ridl., J. Straits Branch Roy. Asiat. Soc. 44 (1905) 187 \& Mat. Fl. Malay Penins. 3 (1907) 49-50; Merr., J. Straits Branch Roy. Asiat. Soc., special ed., (1921) (1921) 86; Ridl., Fl. Malay Penins. 5 (1925) 129. - Type: Malaysia, Sabah, P. Labuan, Barber 231 (K, holo).

Slender, heterophyllous, root-climbing liane to $7 \mathrm{~m}$. Shoot system only weakly differentiated into flowering and non-flowering branches; eocaul thread-like, with scattered minute bracts, then abruptly becoming shingling; seedling shingle-leaved, then abruptly producing adult leaves. Leaves mid- to deep green adaxially, slightly paler abaxially, stiffly chartaceous, drying greyish green with the midrib pale yellow and prominently raised abaxially; petiole $3-8 \times 0.3-0.35 \mathrm{~cm}$, slender, sheath extending to base of geniculum, clasping basally, prominent; blade $6-19 \times 1.5-7 \mathrm{~cm}$, ovate to 

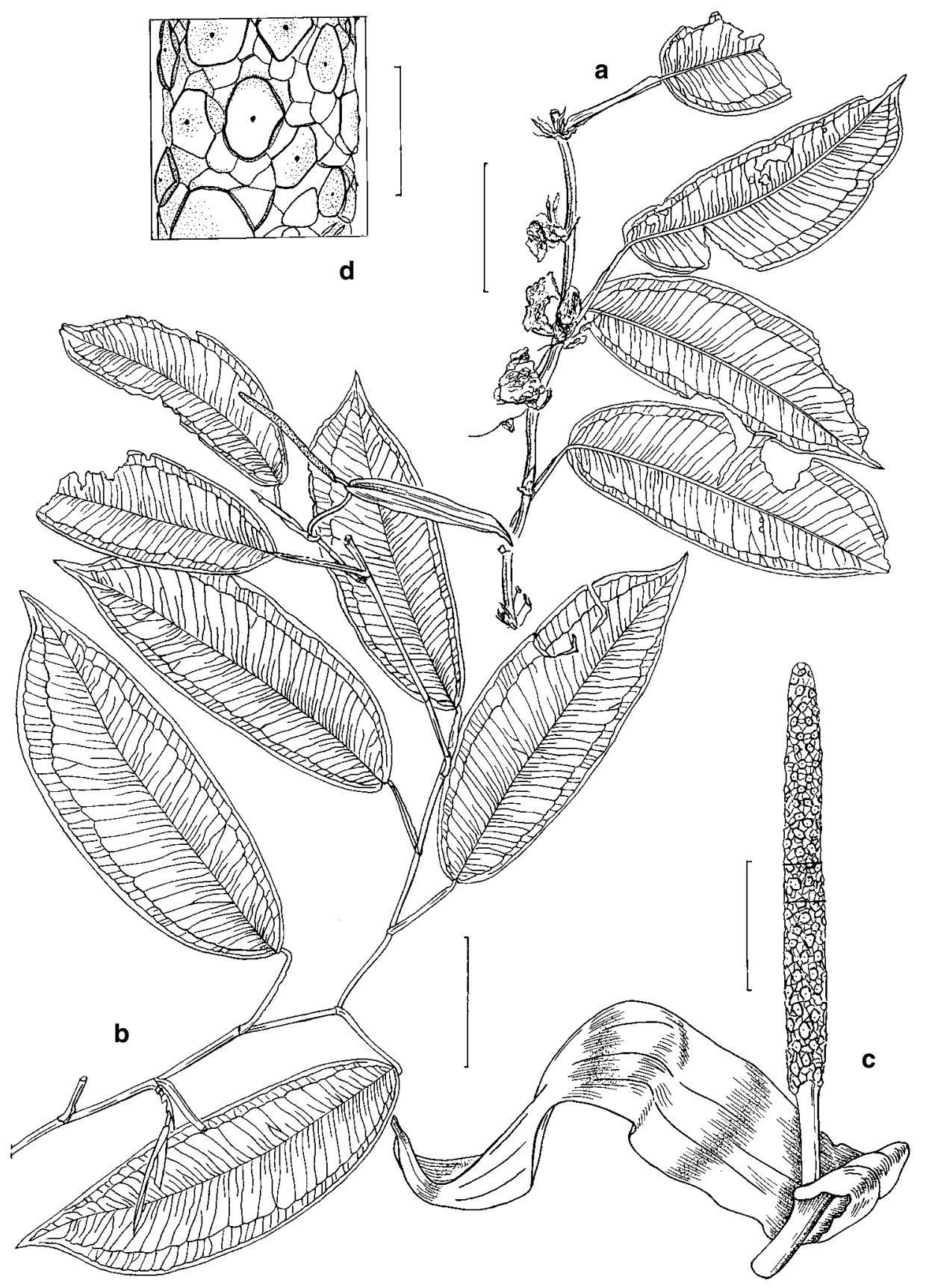

Fig. 18. Pothos leptostachyus. $\mathbf{a}$, mature sterile shoot; $\mathbf{b}$, fertile shoot; $\mathbf{c}$, inflorescence; $\mathbf{d}$, spadix detail.: $\mathrm{a}-\mathrm{d}$, Boyce 1218. Scale bars: $\mathrm{a}=4 \mathrm{~cm} ; \mathrm{b}=8 \mathrm{~cm} ; \mathrm{c}=1.5 \mathrm{~cm} ; \mathrm{d}=2.5 \mathrm{~mm}$. 


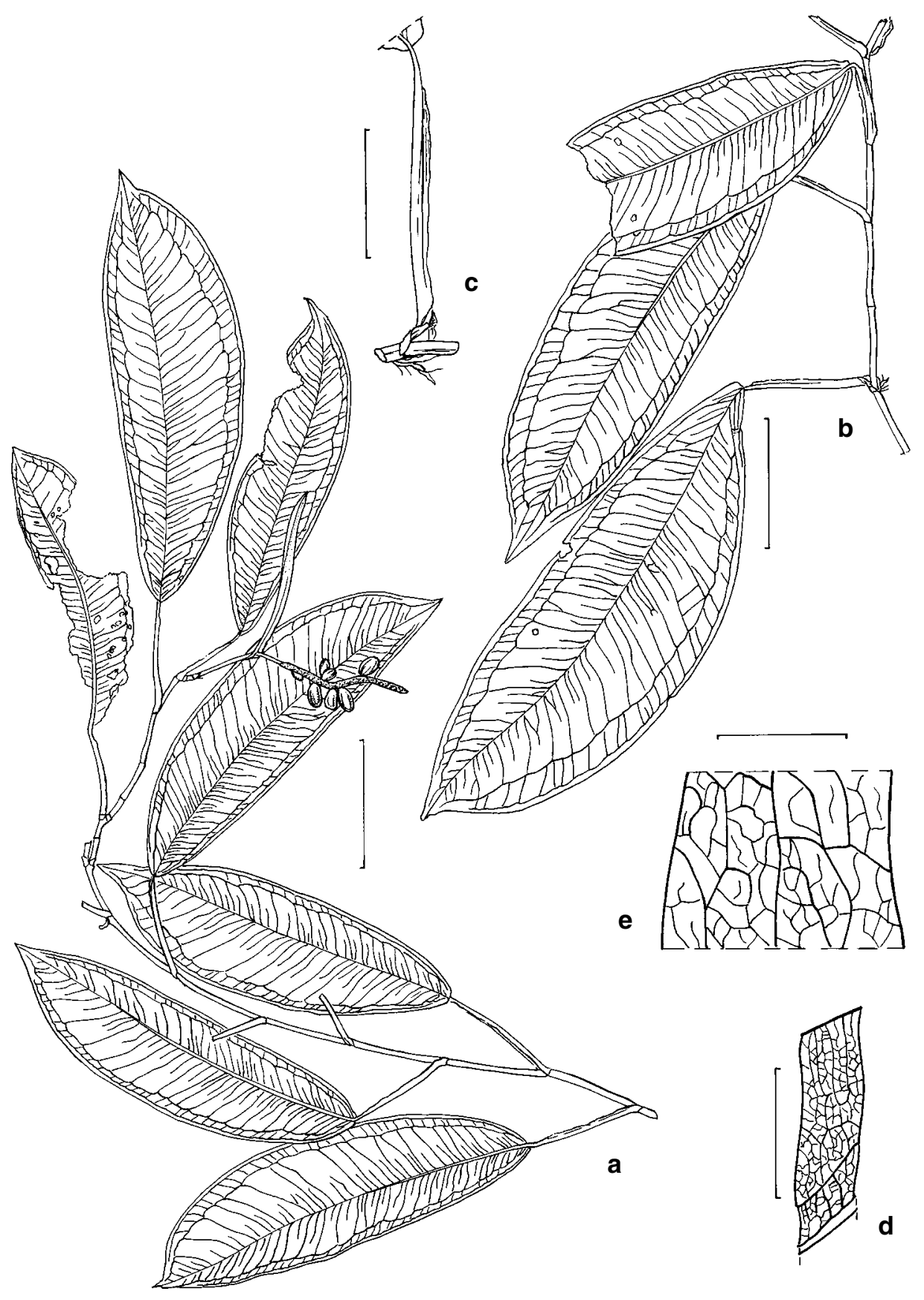

Fig. 19. Pothos leptostachyus. a, fertile shoot; $\mathbf{b}$, mature sterile shoot; $\mathbf{c}$, petiole detail; $\mathbf{d}$, venation detail with midrib and intramarginal veins; e, venation detail: $\mathrm{a}-\mathrm{e}$, Boyce 1218 . Scale bar: $\mathrm{a}=8 \mathrm{~cm}$; $\mathrm{b}=8 \mathrm{~cm} ; \mathrm{c}=3 \mathrm{~cm} ; \mathrm{d}=3 \mathrm{~cm} ; \mathrm{e}=5 \mathrm{~mm}$. 
elliptic or lanceolate, base acute to obtuse, apex attenuate-mucronate, acute or attenuate, minutely apiculate, often falcate; primary lateral veins arising at almost $90^{\circ}$, intramarginal veins 2 per side, the outer intramarginal vein remaining very close and parallel to margin. Inflorescence solitary, usually subtended by cataphylls on condensed short shoots arising from below the axils of distal leaves, occasionally from such shoots arising (persisting?) on leafless older stems, rarely terminal on leafy shoots, held inverted beneath the shoot by reflexing of the peduncle; peduncle $2-4 \times 0.2-0.3 \mathrm{~cm}$, very stout, reflexed $90-180^{\circ}$ at the base, green to dark purple-green. Spathe $2.5-4 \times$ $0.25-0.3 \mathrm{~cm}$, lorate to lorate-lanceolate, strongly reflexed and appressed to peduncle, base minutely cochleate on the peduncle, apex acute, apiculate, green to dull purplegreen, stiffly leathery. Spadix sessile, $2-7 \times 0.3-0.4 \mathrm{~cm}$, cylindrical to taperingcylindrical, deep purple-brown. Flowers c. $1.3 \mathrm{~mm}$ diam., with 6 free tepals and 6 stamens. Infructescence with numerous berries; fruits 7-15 $\times 4-8 \mathrm{~mm}$, ellipsoid, ripening red; seeds not observed. - Fig. 20, 21.

Distribution - Malesia: Sumatera, Peninsular Malaysia and Borneo. Common.

Habitat - In a wide range of habitats from primary and disturbed lowland forest on clays to ridgetop kerangas, 10-1800 m altitude.

Notes - Pothos barberianus is a ubiquitous element of the forests of Peninsular Malaysia and Borneo. In its typical guise (inflorescence pendent by the sharply reflexed peduncle, spathe strongly reflexed and spadix only just exceeding the greatly enlarged peduncle) it is unmistakable. However, some collections from Sabah are notable for their robustness and for the spadix greatly exceeding the peduncle in length; they approach $P$. longivaginatus.

Other specimens examined: SUMATERA: Riau Prov., Siak, Kelaulan River, Ridley 9014 (K, SING). PENINSULAR MALAYSIA: Selangor Bk. Lagong F.R., KEP 78970 (K, KEP); Perak, Maxwell's Hill, Curtis s.n. (SING); Perak, Larut, Kunstler ('Dr King's Collector') 3175 (K, P, US); Perak, Maxwell's Hill, Ridley s.n. (SING); Perak, Larut, Ridley 11285 (SING); Perak, Tupai, Wray 2338 (SING); Perak, Briah Larial, Wray 4212 (BM, SING); Perak, Maxwell's Hill, Wray 4235 (BM, SING). BORNEO: SARAWAK: 7th Div., Belaga, Ulu Sebako, Ashton 518212 (SAR, K); 1st Div., Semengoh F.R., Brunig 4805 (SAR); 4th Div., Lambir hills, Burtt \& Woods 2475 (E, SAR); 7th Div., Balingain, Rumah Tememggong, Begrih, Bawan, Chai S 19456 (K, SAR); 5th Div., Limbang, Tg. Long Amok, Sg. Ensungei, Ulu Medamit, George et al. $S 42867$ (K, KEP, L, SAR, SAN, US); 1st Div., Kuching, Haviland 625 (K); 1st Div., Kuching, Haviland 938 (SING); 1st Div., Kuching, Hewitt A1 (SING); 1st Div., Tebedu, Bk. Simurus, Mohtar et al. S 49292 (K, SAR, US); 4th Div., Bintulu, foot of Lambir Hills N.P., 20th miles Miri - Bintulu, Paie \& Yeo S 38478 (K, KEP, L, SAN, SAR, US); 1st Div., Matang ridge, Stevens et al. 263 (A, SAR); 1st Div., G. Buri, P.C. Yii S43927 (K, L, SAR, US). BRUNEI DARUSSALAM: Belait, Ulu Ingei, Bk. Bt. Patam, Boyce 304 (BRUN, K); Boyce 316 (BRUN, K); Temburong, Amo, Bk. Belalong, J. Dransfield et al. 7176 (BRUN, K); Temburong, Amo, Bk. Belalong, L.P.382, valley E of campsite, J. Dransfield et al. 7405 (BRUN, K). SABAH: Kudat, Boden-Kloss SFN 19293 (SING, UCL); Tenom, Ulu Senagong, above Sg. Senagong, Boyce 1435 (K, SAN, SP); Tenom, Keningau road, Kg. Matailangm $4.5 \mathrm{~km}$ before Tenom, Boyce 1437 (K, SAN, SP); Tambunan, G. Trusmadi, Fidilis SAN 125457 (E, K, SAN); Sandakan, Bidu, 2 miles above Kiabau, Meijer SAN 43823 (SAN); Sandakan, Kebun Cina, Meijer SAN 124380 (K, L, SAN, SAR); Lamag, Kinabatangan, Karamuak, Sg. Kerang, Muroh SAN 70601 (SAN); Belarun, Telupid, Bk. Tangkunan, T.V. Station road, Rahim et al. SAN 93283 (K, L, SAN, SAR); Kota Belud, Mt Templer F.R., S of Sg. Talupit, Shea \& Minjulu SAN 76257 (K, L, SAN). KALIMANTAN: C Kalimantan, Sampit River, Permantang, S of Kuala Kwajan, Ashton 13384 (BM); W Kalimantan, Serawai, 8 km NE of Desa Jelundung, Bt. Lintang, $1 \mathrm{~km} \mathrm{SE}$ of camp, environs of S. Serawai, Church et al. 1685 (A, BO, K); C Kalimantan, Upper Katingan (Mendawi) River area, c. 50-100 km WNW of Tumbang Samba, Mogea 4442 (BO).

\section{Pothos longivaginatus Alderw.}

Pothos longivaginatus Alderw., Bull. Jard. Bot. Buitenzorg, III, 1 (1920) 380. - Type: Indonesia, Kalimantan, Sg. Ikang, 1896, Jaheri sub Nieuwenhuis 1159 (BO, holo). 


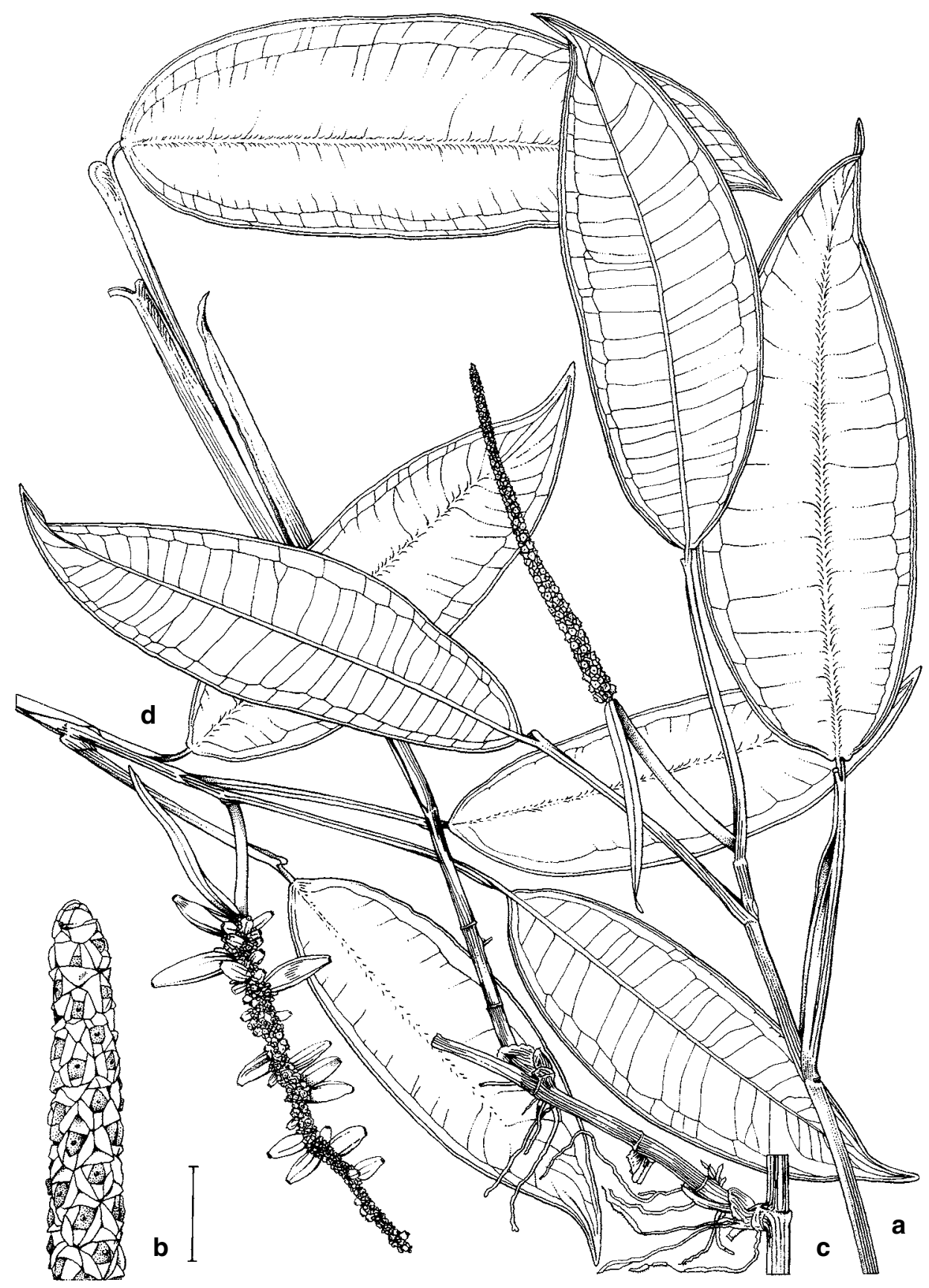

Fig. 20. Pothos barberianus. $\mathbf{a}$, fertile shoot; $\mathbf{b}$, spadix detail; $\mathbf{c}$, adult adherent shoot; $\mathbf{d}$, fertile shoot with infructescence: a-c, Paie \& Yeo S 38478; d, P.C. Yii S43927. Scale bar: a, c, d, = 2 cm; b = $2.7 \mathrm{~mm}$. 


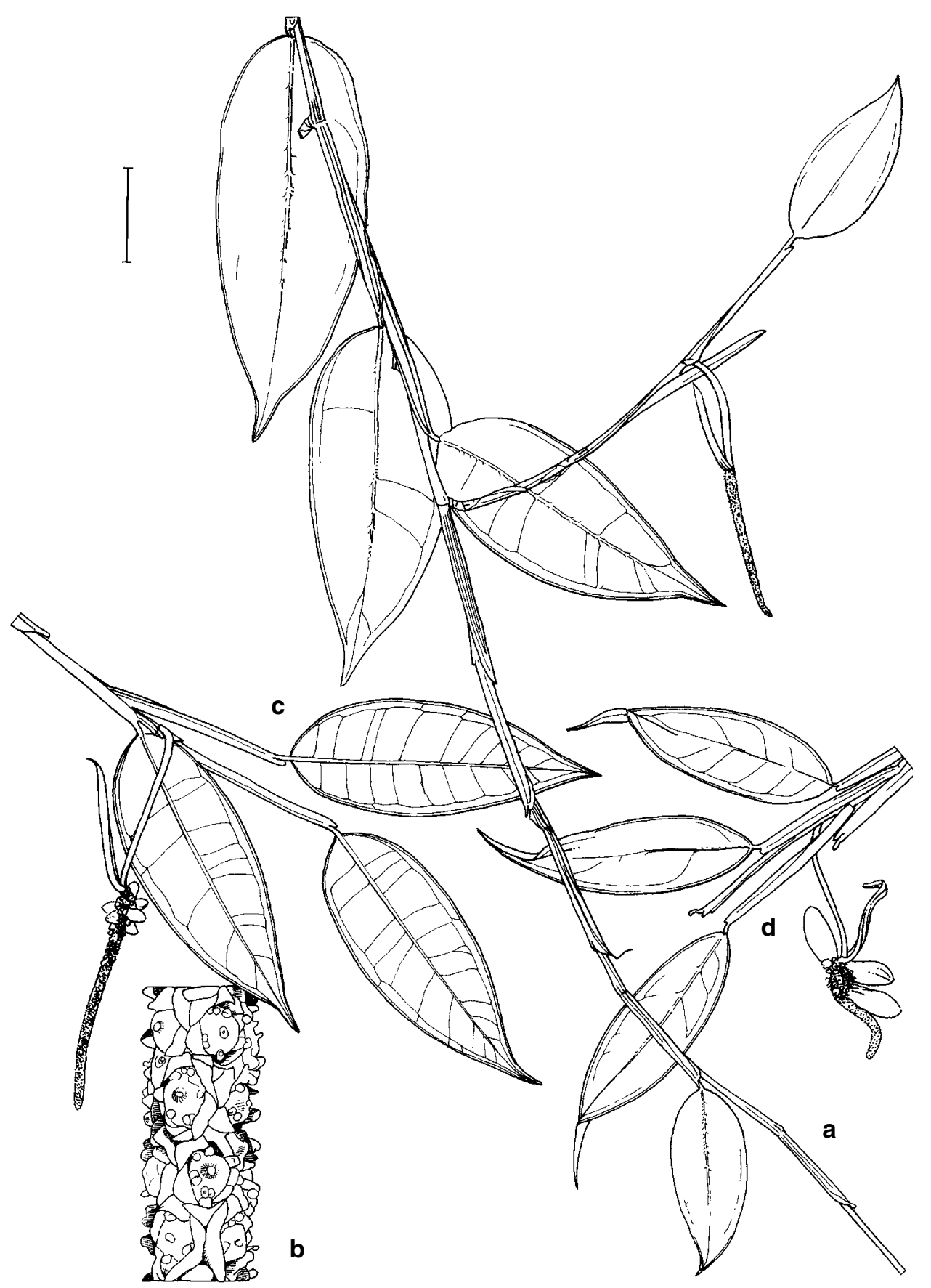

Fig. 21. Pothos barberianus. a, fertile shoot; $\mathbf{b}$, spadix detail; $\mathbf{c}$, fertile shoot with young infructescence; d, fertile shoot with mature infructescence: a-c, Barber 231; d, Kunstler ('Dr King's Collector') 3175. Scale bar: $a, c, d,=2 \mathrm{~cm} ; \mathrm{b}=2.2 \mathrm{~mm}$. 
Pothos kinabaluensis Furtado, Gard. Bull. Straits Settlem. 8 (1935) 149, syn. nov. - Type: Malaysia, Sabah, Tenompok, 26 Mar 1932, Furtado sub. Clemens \& Clemens 29155 (SING, holo; iso A, BM, BO, K).

Robust, heterophyllous, root-climbing liane to $7 \mathrm{~m}$. Shoot system only weakly differentiated into flowering and non-flowering branches; eocaul not seen; seedling shingle-leaved, abruptly producing adult leaves. Leaves deep green adaxially, paler abaxially, stiffly chartaceous, drying greyish to brownish green; petiole 6-18.5 $\times 0.3-0.5 \mathrm{~cm}$, stout, sheath prominent, extending to base of geniculum, margins later scarious, clasping basally; blade $11-28 \times 4-10 \mathrm{~cm}$, ovate to elliptic or lanceolate, base acute to obtuse, apex attenuate-mucronate, acute or attenuate, minutely apiculate, often falcate; primary lateral veins arising at $70-80^{\circ}$, intramarginal veins 2 per side, the outer intramarginal vein remaining very close and parallel to margin. Inflorescence solitary, occasionally paired, usually subtended by cataphylls on condensed short shoots arising from below the axils of distal leaves, occasionally from such shoots arising (persisting?) on leafless older stems, rarely terminal on leafy shoots, held inverted beneath the shoot by reflexing of the peduncle; peduncle $(3.5-) 12-16 \times 0.3-0.35 \mathrm{~cm}$, very stout, reflexed $90-180^{\circ}$ at the base, green to dark purple-green. Spathe (3-)6-9 $\times$ (0.3-)0.4-1.5 cm, lorate, strongly reflexed and appressed to peduncle, base minutely cochleate on the peduncle, apex acute, apiculate, green to dull purple-green, stiffly leathery. Spadix sessile, $(2.5-) 6-7 \times 0.3-0.5 \mathrm{~cm}$, cylindrical to tapering-cylindrical, deep purple-brown. Flowers c. $1.3 \mathrm{~mm}$ diam., with 6 free tepals and 6 stamens. Infructescence with numerous berries; fruits 10-15 $\times 4-7 \mathrm{~mm}$, conical-ellipsoid, ripening red; seeds not observed. - Fig. 22.

Distribution - Malesia: endemic to Borneo.

Habitat - Mixed dipterocarp forest on slopes, ridges and streambanks on clay, sandstone and shale, 23-1525 m altitude.

Notes - Very close to $P$. barberianus, differing primarily in the overall greater dimensions and the typically much longer peduncle.

The type of $P$. longivaginatus is an excellent match for that of $P$. kinabaluensis and treated here as synonymous. Almost all specimens hitherto annotated in herbaria as $P$. hosei are either P. longivaginatus or P. brevistylus (q.v.).

Other specimens examined: BORNEO: SARAWAK: 'Native collector' 333 (BO, K, P, US). BRUNEI DARUSSALAM: Temburong, Sg. Temburong at Kuala Belalong, ridge W of River, Boyce 440 (AAU, BRUN, K); Temburong, Selapon, hill E of village, J. Dransfield 6934 (BRUN, K); Temburong, Selapon, Bt. Apoi, Bk. Tempedak, E of village, J. Dransfield et al. 7465 (BRUN, K); Temburong, Batu Apol F.R., ridge W of Kuala Belalong Field Studies Center; Poulsen 147 (AAU, BRUN, K). SABAH: Ranau, Crocker range, Bk. Lugas, Kg. Himbaan, $8.5 \mathrm{~km}$ SE of Tenompok, Beaman 8463 (K); Tenompok, Clemens E Clemens 28514 (BM, K, SING); Penibukan, Gurulau spur, Clemens \& Clemens 50710 (BM, SING); Tawau, Elmer 21822 (A, BM, BO, C, K, MO, P, SING, UCL).

\section{Pothos lancifolius Hook.f.}

Pothos lancifolius Hook.f., Fl. Brit. Ind. 6 (1893) 554; Engl. in Engl., Pflanzenr. 21 (IV.23B) (1905) 40; Ridl., Mat. Fl. Malay Penins. 3 (1907) 51 \& Fl. Malay Penins. 5 (1925) 130-131; Boyce, Blumea 45 (2000) 193-195, fig.12. - Type: Malaysia, Perak (probably Bk. Larut), Scortechini $576 b$ (K, holo; iso BM, CAL, E, SING).

Pothos penicilliger Gagnep., Notul. Syst. 9 (1941) 135. - Type: Vietnam, Col des Nuages, near Tourane (Danang), Poilane 8089 (P, holo; iso GH, SAI).

Slender to somewhat robust, heterophyllous, root-climbing liane to $8 \mathrm{~m}$. Shoot system well differentiated into adherent non-flowering and flowering free lateral branches; eocaul not observed; seedling shingle-leaved, often producing long, adherent strongly 


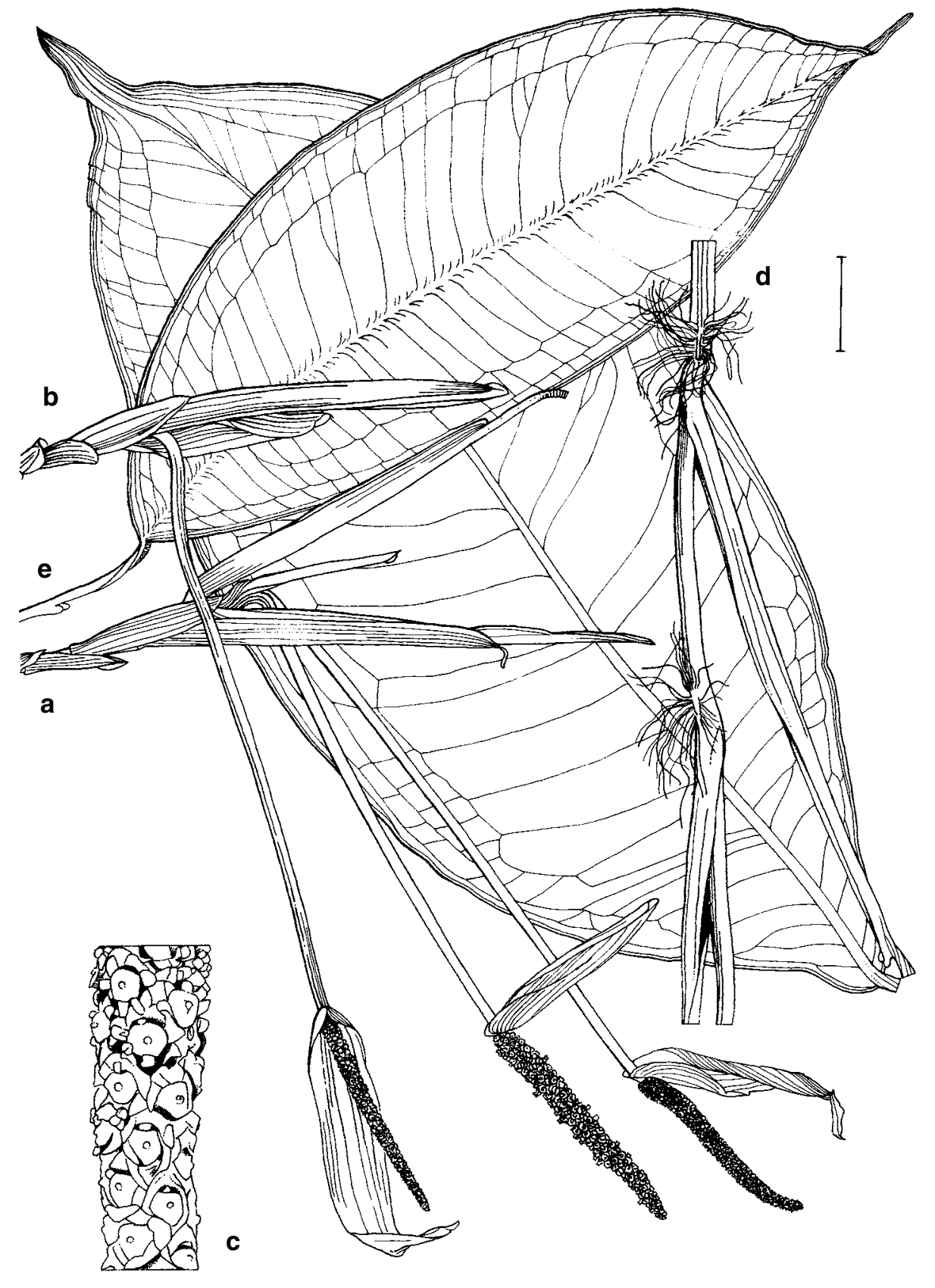

Fig. 22. Pothos longivaginatus. a, b fertile shoots; c, spadix detail; $\mathbf{d}$, adult adherent shoot; e, leaf: a-c, Clemens \& Clemens 29155; d, Brooke 10699; e, 'Native collector' 333. Scale bar: a, b, d, e, = 2 cm; c $=2.7 \mathrm{~mm}$. 
flattened feeding roots with a prominently warty-spiny epidermis. Leaves mid-green adaxially, slightly paler abaxially, stiffly chartaceous, drying dull greenish brown, midrib paler, prominently raised; petiole $4-14 \times 0.15-0.2 \mathrm{~cm}$, slender, sheath rather prominent, extending to just below geniculum, basally clasping, apically briefly ligulate; blade $10-25 \times 2.5-10 \mathrm{~cm}$, ovate to elliptic or narrowly lanceolate, base rounded, apex acute to long-attenuate, minutely apiculate; primary lateral veins arising at c. $60^{\circ}$, intramarginal veins 2 per side, the lowermost arising from the base, the next arising from the lower part of the midrib, outer intramarginal vein remaining very close and parallel to margin, inner vein c. $5 \mathrm{~mm}$ distant, both reaching the leaf tip. Inflorescence solitary, occasionally paired on a foliage-leafless shoot arising below a foliage leaf, less often terminal on a leafy shoot; peduncle $1.5-5 \times 0.15-0.3 \mathrm{~cm}$, stout, sharply bent, dull greenish yellow. Spathe $2.5-10 \times 1-4 \mathrm{~cm}$, lanceolate, slightly cucullate, base barely decurrent on the peduncle, apex acuminate, green to purplishgreen, slightly softly-leathery. Spadix sessile, $1.5-5 \times 0.3-0.9 \mathrm{~cm}$, cylindrical, dark yellow to yellow-green. Flowers c. $1.5 \mathrm{~mm}$ diam., with 6 free tepals and 6 stamens. Infructescence with numerous berries, mostly born towards the bottom of the spadix; fruit 10-15 × 10-11 mm, ellipsoid to bottle-shaped, ripening deep scarlet, with prominent basal leathery and chartaceous tepal remains and a large stigmatic remnant; seeds c. 4-6 × 2-3 mm diam., ellipsoid. - Fig. 23.

Distribution —Vietnam. In Malesia: Peninsular Malaysia.

Habitat - Degraded dry to damp seasonal evergreen upper hill to lower montane forest on clay soils over granite, 900-1300 m altitude.

Notes - With the enlarged and sharply bent peduncle, P. lancifolius most resembles $P$. barberianus, from which it may be distinguished by the chartaceous spathe enclosing the spadix and persisting, though degrading, through to fruiting (vs. spathe coriaceous, reflexing, falling during fruit maturation in P. barberianus).

In the peduncle characters $P$. lancifolius is also morphologically similar to $P$. kingii although it may be distinguished from $P$. kingii by the lanceolate, not cucullate, spathe and the bottle-shaped fruits with large, broad, stigmatic remains.

Confusion is also possible with $P$. leptostachyus, from which $P$. lancifolius may be separated by the deflexed inflorescence, lanceolate (versus lorate) spathe and sessile spadix.

Other specimens examined: PENINSULAR MALAYSIA: Pahang, Fraser's Hill, Henderson FMS 11462 (UCL); Fraser's Hill, Bishop's Path, Kiew 3353 (UPM); Fraser's Hill, Sungei Yeh, Nur SFN 11145 (BO, K, SING); Cameron Highland, Nur SFN 32918 (A, K, KEP, MO, SING, UCL, US).

\section{Pothos philippinensis Engl.}

Pothos philippinensis Engl. in Engl., Pflanzenr., 21(IV.23B) (1905) 315; Merr., Enum. Philippine Pl., 1 (1922) 173. - Type: Philippines, Luzon, Bataan, Lamao River, Mar 1904, Barnes FB 369 (B, lecto selected here; isolecto US). Engler cited two conspecific syntypes. The second is Philippines, Luzon, Bataan, Lamao River, Mt Mariveles, May 1904, Whitford 341 (K, US). The specimen chosen as lectotype is a fertile one annotated with this name by Engler.

[Pothos peninsularis Elmer, Leafl. Philippine Bot. 10 (1938) 3628 [non Alderw. (1920)], nom. inval. descr. angl. - Based on: Philippines, Luzon, Sorsogon Prov., Irosin (Mt Bulusan), Aug 1916, Elmer 17050 (sheets seen at A, MO)].

Somewhat robust, (heterophyllous?), root-climbing liane to $12 \mathrm{~m}$. Shoot system well differentiated into adherent non-flowering and flowering free lateral branches; eocaul and seedling not observed. Leaves stiffly chartaceous, drying dull greenish brown, midrib slightly paler; petiole $3-10.5 \mathrm{~cm}$ long, slender, sheath rather prominent, extending to just below geniculum, basally clasping, apically briefly ligulate; blade 


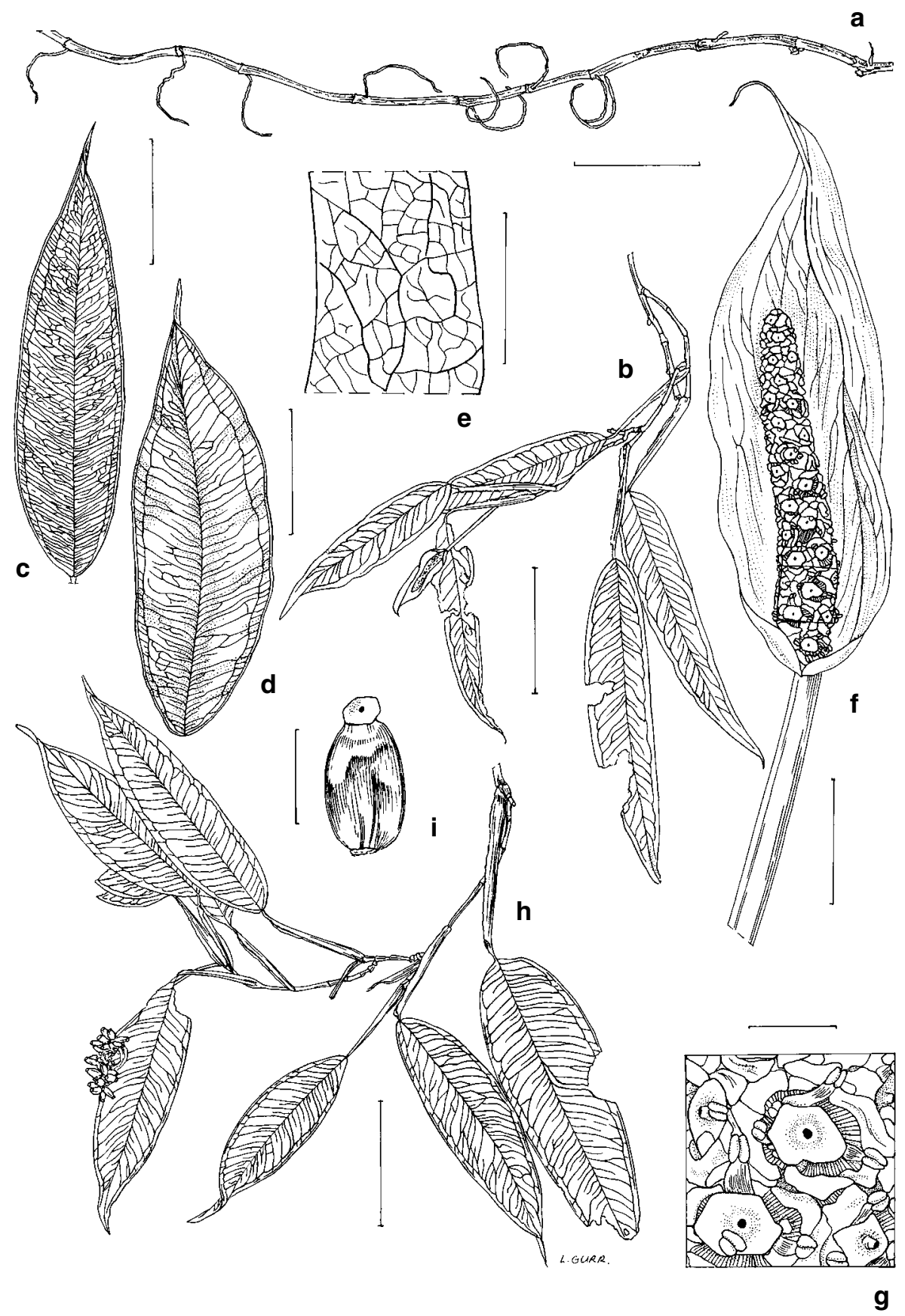

Fig. 23. Pothos lancifolius. $\mathbf{a}$, older leafless sterile mature shoot; $\mathbf{b}$, fertile shoot; $\mathbf{c}$, leaf: minus petiole; $\mathbf{d}$, leaf: minus petiole; e, venation detail; $\mathbf{f}$, inflorescence; $g$, spadix detail; $\mathbf{h}$, fertile shoot: bearing infructescence; i, mature berry: a \& c, Poilane 8089; b, f \& g, Vu Xuan Phuong 1190; d \& e, h \& i, SovietVietnam Expedition 4120 . Scale bar: $\mathrm{a}_{1}=40 \mathrm{~mm} ; \mathrm{b},=40 \mathrm{~mm} ; \mathrm{c}_{,}=40 \mathrm{~mm} ; \mathrm{d},=60 \mathrm{~mm}$;,$=3 \mathrm{~mm}$; $\mathrm{f},=5 \mathrm{~mm} ; \mathrm{g},=1 \mathrm{~mm} ; \mathrm{h},=60 \mathrm{~mm} ; \mathrm{i},=5 \mathrm{~mm}$. 


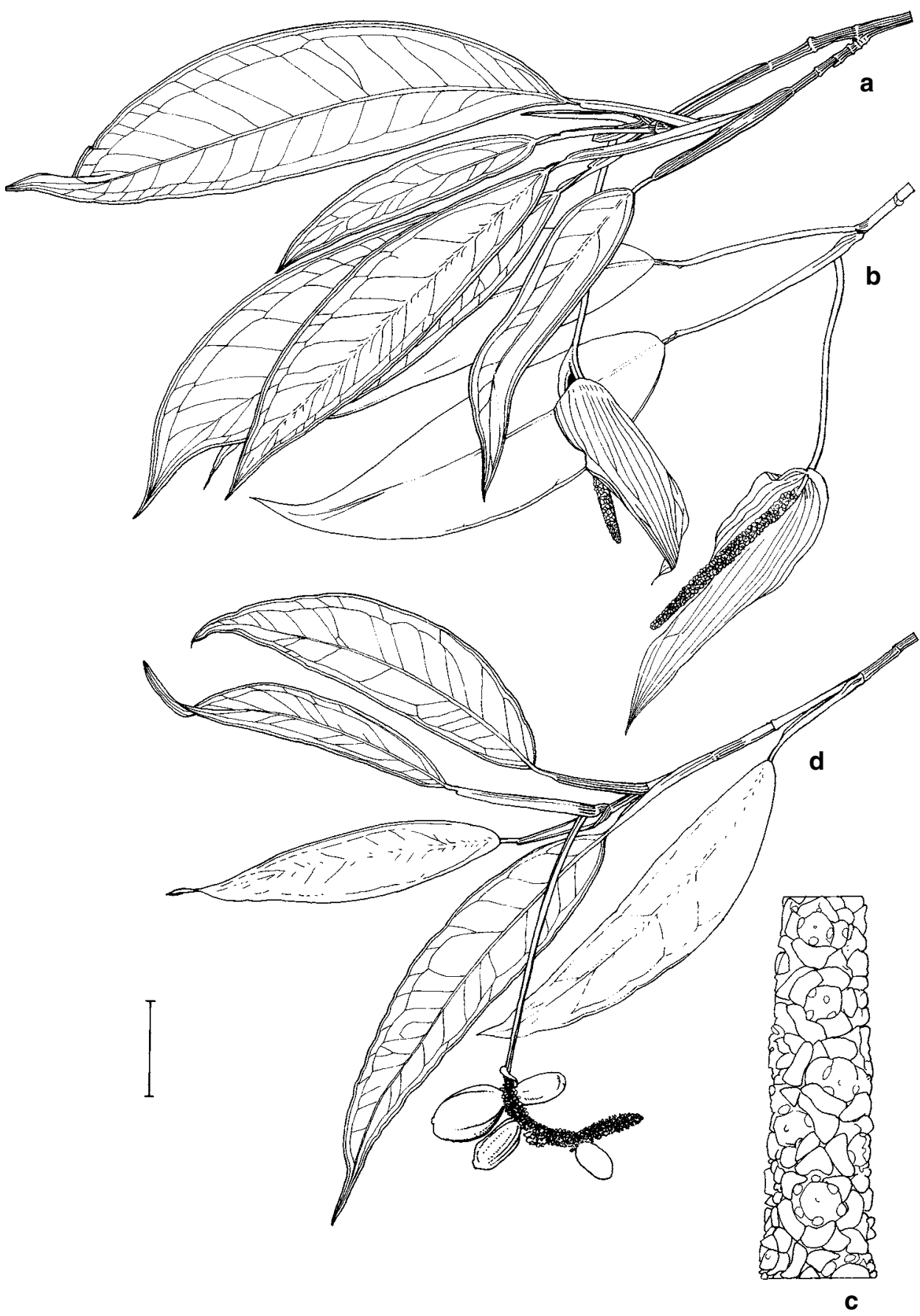

Fig. 24. Pothos philippinensis. a, b, fertile shoots in flower; $\mathbf{c}$, spadix detail; $\mathbf{d}$, fertile shoot with mature infructescence: a, Williams 486; b-c, Foxworthy BS 1640; d, Leonardo Co 3548. Scale bar: a, b, $\mathrm{d}=2 \mathrm{~cm} ; \mathrm{c}=2.2 \mathrm{~mm}$. 
6-26 $\times 2-9 \mathrm{~cm}$, ovate to oblong elliptic or narrowly lanceolate, base rounded, rarely minutely truncate or cordate, apex acute to long-attenuate, falcate, apiculate; primary lateral veins arising at c. $45^{\circ}$, intramarginal veins 2 per side, the lowermost arising from the base, outer intramarginal vein remaining very close and parallel to margin. Inflorescence solitary, terminal on a leafy shoot; peduncle (4.5-)8-12 × c. $0.2 \mathrm{~cm}$, stout, nodding to deflexed. Spathe 5-10 $\times 1.5-2.5 \mathrm{~cm}$, triangular, subcucullate, base clasping peduncle, apex long-acuminate, softly leathery. Spadix sessile but basally decurrent on spathe, 3-7 $\times 0.3-0.4 \mathrm{~cm}$, cylindrical. Flowers c. $1.3 \mathrm{~mm}$ diam., with 6 free tepals and 6 stamens. Infructescence with numerous berries, mostly born towards the bottom of the spadix; fruit 10-15 × 10-11 mm, ellipsoid- to bottle-shaped, ripening deep scarlet, with prominent basal chartaceous tepal remains and a large stigmatic remnant; seeds not observed. - Fig. 24.

Distribution - Malesia: endemic to and widespread in the Philippines.

Habitat - Lowland to hill, primary to secondary rainforest, 20-650 m altitude.

Note - Very close to $P$. lancifolius, but distinguishable by the larger inflorescences, longer peduncle, wider, subcucullate triangular spathe and generally much more robust habit. It is not known if $P$. philippinensis has a shingling stage.

Other specimens examined: PHILIPPINES: Palawan, Puerto Princessa (Mt Pulgar) Elmer 13039 (E); Luzon, Apayao Fénix BS 28190 (BM, K, P, US) Luzon, Bataan, Lamas F.R., Foxworthy BS 1640 (A, BO, K, US); Luzon, Isabella Prov., Divilacan, Barangay Bicobian, lower slopes of Tan-awan ridge, c. $15 \mathrm{~km}$ NW of Palanan Point, Leonardo Co3548 (A, K, L, PNH, US); Luzon, Manila, Loher 2457 (K); Sibuyan, Visayas, Mt Giting-giting, Madulid 6913 (A, PNH); Palawan, Penigisan, Ølsen 274 (C); Luzon, Nueva Ecija Prov., Mt Umigan, Ramos \& Edaño BS 26414 (US); Luzon, Bulacan Prov., Angat, Ramos \& Edaño BS 34031 (SING); Luzon, Palanan, Dimapnat, Ridsdale et al. ISU 556 (K, L); Luzon, Bataan, Lamao River, Mt Mariveles, Williams 486 (A, K, US).

\section{Pothos englerianus Alderw.}

Pothos englerianus Alderw., Bull. Jard. Bot. Buitenzorg, III, 1 (1920) 381. — [Pothos sumatranus Engl. Bot. Jahrb. Syst. 25 (1898) 5 \& in Engl., Pflanzenr. 21 (IV.23B) (1905) 40, nom. illeg., non Miq. (1861)]. — Type: Indonesia, Sumatera, 1880, Forbes 2361 (BM, lecto selected here). Engler cites two syntypes. The other [Sumatera, Hillebrand s.n. (B)] is sterile and unsuitable as a lectotype.

[Pothos engleri Furtado, nom. ined. in sched. BM]

Slender root-climbing liane. Shoot system well differentiated into adherent nonflowering and flowering free lateral branches; eocaul and seedling not observed. Leaves chartaceous, drying dull greenish brown; petiole $1.5-2 \times 0.1-0.3 \mathrm{~cm}$, relatively stout, sheath rather prominent, extending c. $2 / 3$ length of petiole, basally spreading, apically decurrent; blade 3-15 × 1-4.5 cm, oblong-ovate to oblong-elliptic, base rounded, apex attenuate, apiculate; primary lateral veins arising at c. $60-70^{\circ}$, intramarginal veins 2 per side, the lowermost arising from the base, the next arising from the lower part of the midrib, outer intramarginal vein remaining close and parallel to margin, inner vein c. $5 \mathrm{~mm}$ distant, both reaching the leaf tip. Inflorescence solitary on a foliage-leafless shoot arising below a foliage leaf, peduncle $4-6 \times$ c. $0.1 \mathrm{~cm}$, rather stout, reflexing at c. $90^{\circ}$ so holding inflorescence below shoot. Spathe 3-4 $\times 1-2.5$ $\mathrm{cm}$, ovate-lanceolate, slightly cucullate, base slightly clasping peduncle, apex acuminate. Spadix sessile c. $2 \times 0.3 \mathrm{~cm}$, slightly tapering-cylindrical. Flowers c. $1.2 \mathrm{~mm}$ diam., with 6 free tepals and 6 stamens. Infructescence with few berries (observed from scars only); fruit and seeds not observed. - Fig. 25.

Distribution - Malesia: endemic to Sumatera. 


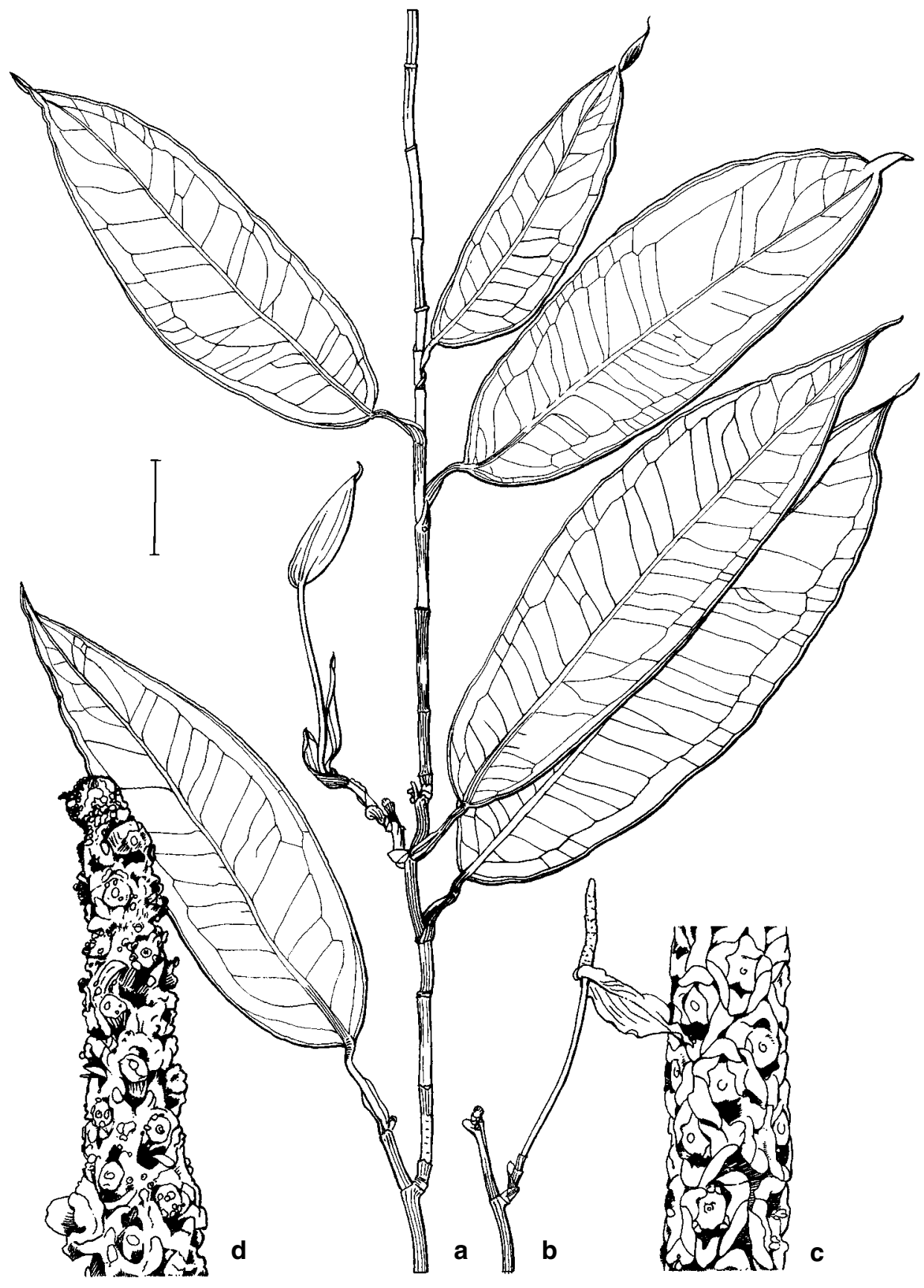

Fig. 25. Pothos englerianus. a, fertile shoot; $\mathbf{b}$, inflorescence late in anthesis; $\mathbf{c}$, spadix detail (middle); d, spadix detail (tip): a-d, Forbes 2361 . Scale bar: $a, b,=2 \mathrm{~cm} ; \mathrm{c}=3.3 \mathrm{~mm} ; \mathrm{d}=1.7 \mathrm{~mm}$. 
Habitat - Habitat not specifically recorded, although $1600 \mathrm{~m}$ altitude is noted on Hillebrand's syntype.

Note - Similar to P. lancifolius (Peninsular Malaysia and Vietnam) but distinguished by the reflexed (not curving) peduncle, broader spathe, and in the shorter and broader petiolar sheath.

Other specimen examined: SUMATERA: No further data, Hillebrand s.n. (B).

\section{Pothos atropurpurascens M. Hotta}

Pothos atropurpurascens M. Hotta, Acta Phytotax. Geobot. 22 (1966) 1. - Type: Malaysia, Sarawak, 4th Div., Bintulu, along Ulu Sg. Kakus from Sg. Biyah to Ulu S. Mubong, 11 Nov 1963, Hirano \& Hotta 1011 (KYO, holo; iso L).

Slender to rather robust, heterophyllous, root-climbing liane. Shoot system well differentiated into free lateral flowering and clinging non-flowering branches; eocaul not observed; seedling shingle-leaved. Leaves mid-green adaxially, slightly paler abaxially, chartaceous, drying dull green with the midrib pale yellow and slightly raised; petiole $2-10 \times 0.2-0.3 \mathrm{~cm}$, slender, sheath extending to geniculum, clasping basally and frequently for almost its entire length, with a short apical ligule; blade $7-25.5 \times 2-8 \mathrm{~cm}$, ovate-elliptic to narrowly oblong-elliptic or oblanceolate, base acute to obtuse, apex rounded and abruptly cuspidate, falcate, minutely apiculate; primary lateral veins arising at $65-80^{\circ}$, with 2 intramarginal veins per side, the lowermost arising from the base, subsequent veins arising from the lower part of the midrib, outer intramarginal vein remaining very close and parallel to margin. Inflorescence solitary, terminal on leafy shoots, by reflexing of the peduncle held inverted beneath the shoot; peduncle $(1.5-) 2-8 \times 0.15-0.25 \mathrm{~cm}$, stout, reflexed c. $90^{\circ}$ at the base, yellowish orange-brown. Spathe (2-)4-11 × 2-7 cm, ovate, deeply cucullate, base slightly decurrent on the peduncle, apex acute to attenuate, white stained purple, thinly leathery and prominently net-veined. Spadix sessile, $(1.5-) 2-5.5 \times 0.3-0.7 \mathrm{~cm}$, cylindrical, deep purple-grey. Flowers c. $1.2 \mathrm{~mm}$ diam., with 6 free tepals and 6 stamens. Infructescence with several to many berries; fruits 4-15 $\times 3-10 \mathrm{~mm}$, ovateellipsoid; seeds not observed. - Fig. 26.

Distribution - Malesia: endemic to N Borneo.

Habitat - Primary to disturbed secondary lowland to upper hill forest, occasionally on ultramafics, $125-1230 \mathrm{~m}$ altitude.

Note - Unique in Borneo by the deeply cucullate, softly leathery, white, purpleflushed spathe. Clearly very closely allied to P. kingii (Peninsular Malaysia and southern Thailand) but separable by the abruptly cuspidate leaf tip and thinnertextured, much paler spathe.

Other specimens examined: BORNEO: BRUNEI DARUSSALAM: Labi, Wong Kadir, near Mendaram, Coode 7181 (BRUN, K);Temburong, Selapon, lower slopes of Bk. Beliton, S of village, J. Dransfield 6955 (BRUN, K); Temburong, Batu Apoi F.R., ridge W of Kuala Belalong Field Studies Center, Poulsen 180 (AAU, BRUN, K). SABAH: Sandakan, mile 8 Telupid - Ranau road, Aban $\mathcal{E}$ Saikeh SAN 79445 (K, L, SAN); Ranau, Bk. Kulung, nearBk. Hampuan, SE base of Mt Kinabalu, Beaman 8361 (US); Sandakan, Kabili-Sepilok F.R. compartment 10, Sg. Kinabatangan, Castro 7050 (K, SING); Penibukan, Clemens \& Clemens 31126 (A, BM, K, SING); Penibukan, Clemens \& Clemens 35003 (BM, BO); Penibukan, Dehobang, via Labuan, Clemens \& Clemens s.n. (BM); Sandakan, Sepilok F.R., Gibot SAN 73770 (K, SAN); Sandakan, Sepilok F.R., Jalan H. Tanjong, Lassan SAN 71259 (SAN); Lamag, Ulu Sg. Pin, Madani \& Saigol SAN 90156 (K, KEP, SAN); Sandakan, Sepilok F.R., Meijer SAN 21234 (K, SAN). 


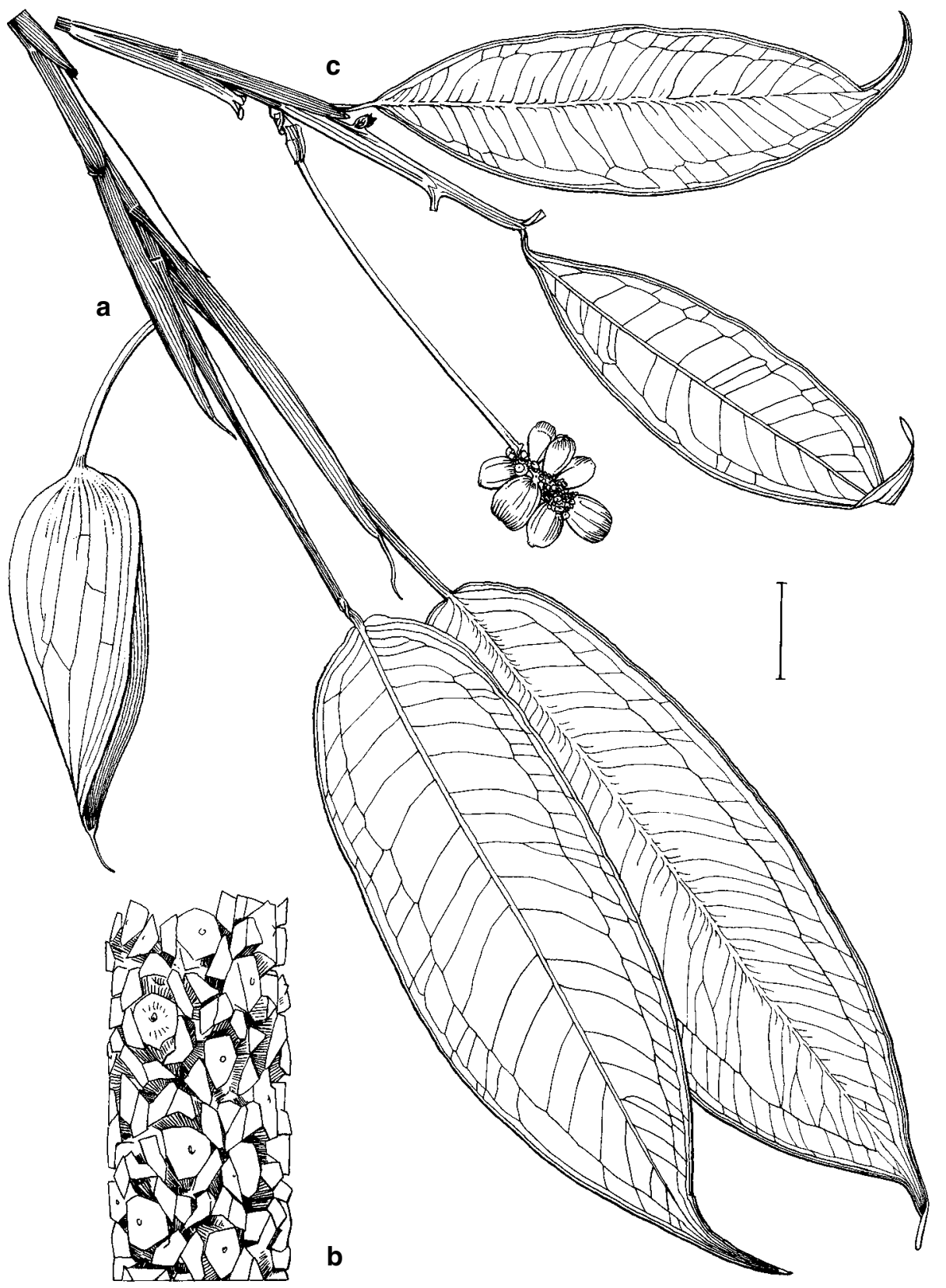

Fig. 26. Pothos atropurpurascens. a, fertile shoot in flower; $\mathbf{b}$, spadix detail; $\mathbf{c}$, fertile shoot with mature infructescence: a, Hirano \& Hotta 1011; b, Clemens \& Clemens 31126; c, Gibot SAN 73770. Scale bar: a, c, $=2 \mathrm{~cm} ; \mathrm{b}=2.2 \mathrm{~mm}$. 


\section{Pothos kingii Hook.f.}

Pothos kingii Hook.f., Fl. Brit. Ind. 6 (1893) 553; Engl. in Engl., Pflanzenr. 21 (IV.23B) (1905) 38; Ridl., Mat. Fl. Malay Penins. 3 (1907) 51 \& Fl. Malay Penins. 5 (1925) 131; Boyce, Blumea 45 (2000) 189-192, fig.11a,11b. - Type: Malaysia, Perak, Larut, Kunstler ('Dr King's Collector') 2723 (K, lecto, isolecto CAL, selected by Boyce (2000: 189)).

Pothos grandispathus Ridl., J. Straits Branch Roy. Asiat. Soc. 41 (1904) 48 ('grandispatha') \& Mat. Fl. Malay Penins. 3 (1907) 51 \& Fl. Malay Penins. 5 (1925) 131. - Type: Malaysia, Penang, W Hill, Curtis s.n. (SING, holo).

Pothos ridleyanus Furtado, Gard. Bull. Sing. 8 (1935) 150. - [Pothos ellipticus Ridl., J. Straits Branch Roy. Asiat. Soc. 41 (1904) 48, nom. illeg., non P. ellipticus Moon ex Miq. (1856) (Sri Lanka)]. — Type: Malaysia, Pahang, Pahang River, Kuala Tembiling, Ridley s.n. (SING, lecto, selected by Boyce (2000: 189)).

Slender, heterophyllous, root-climbing liane to $7 \mathrm{~m}$. Stem?; eocaul not observed; seedling shingle-leaved. Leaves bright to mid-green adaxially, slightly paler abaxially, stiffly chartaceous, drying dull green with the midrib pale yellow and prominently raised; petiole $4-12 \times 0.2-0.25 \mathrm{~cm}$, slender, sheath extending to geniculum, clasping basally on juvenile and mature sterile shoots, prominent and sheathing to $4 / 5$ of its length on fertile shoots; blade 5-25 $\times 2.3-9 \mathrm{~cm}$, ovate to elliptic or lanceolate, base acute to rounded, apex attenuate-mucronate, acute or attenuate, minutely apiculate; primary lateral veins arising at $45-65^{\circ}$, with 3 intramarginal veins per side, the lowermost arising from the base, subsequent veins arising from the lower part of the midrib, outer intramarginal vein remaining very close and parallel to margin, the second and third progressively nearer to the midrib, all reaching the leaf tip. Inflorescence solitary, usually subtended by cataphylls on condensed short shoots in the axils of distal leaves, occasionally from such shoots arising (persisting?) on leafless older stems, rarely terminal on leafy shoots, by reflexing of the peduncle held inverted beneath the shoot; peduncle $2-5 \times 0.15-0.25 \mathrm{~cm}$, stout, reflexed c. $90^{\circ}$ at the base, yellow to orange-brown. Spathe $4-10 \times 2.5-6 \mathrm{~cm}$, ovate, deeply cucullate, base slightly decurrent on the peduncle, apex acute, deep purple inside and out, softly leathery and rather prominently net-veined. Spadix sessile, $2.5-7 \times 0.3-0.8 \mathrm{~cm}$, cylindrical, deep purple-brown. Flowers c. $1 \mathrm{~mm}$ diam., with 6 free tepals and 6 stamens. Infructescence with 4-10 berries; fruits c. 2-4 × 2.5-9 mm, oblong-ellipsoid; seeds not observed. - Fig. $27,28$.

Distribution - Thailand (south peninsular). In Malesia: Peninsular Malaysia.

Habitat - Shady to open areas in wet, occasionally swampy, primary forest, often on steep slopes, 50-1200 $\mathrm{m}$ altitude.

Notes - Distinctive in Peninsular Malaysia due to its deeply cucullate, softly leathery, deep purple spathe. Fertile specimens are instantly recognizable but sterile material could be confused with vegetatively similar P. leptostachyus (with which $P$. kingii is often allopatric), and P. curtisii. Pothos atropurpurascens (Borneo) is most similar but readily separable by the abruptly cuspidate leaf tip and thinner-textured, much paler spathe.

It is remarkable that such a distinctive species could have been described on three separate occasions, especially given that the types are all good specimens and are, it would seem, not open to misinterpretation.

Other specimens examined: PENINSULAR MALAYSIA: Johore, Kota Tinggi, Corner s.n. (SING); Terengganu, Kemaman, Bk. Kajang Corner s.n. (SING); Pahang, near Kota Glanggi, Henderson SING 22411 (SING); Johore, Sg. Kayu, Keah s.n. (SING); Pahang, Fraser's Hill, below lodge, MEDP 1269 (UPM); Perak, Scortechini 1450 (K); Pahang, P. Tawar, Ridley s.n. (SING); Perak, Wray 3277 (SING); Pahang, Endau Rompin, Sg. Kincin, base camp loop, Zainudin 2793 (UKMB). 


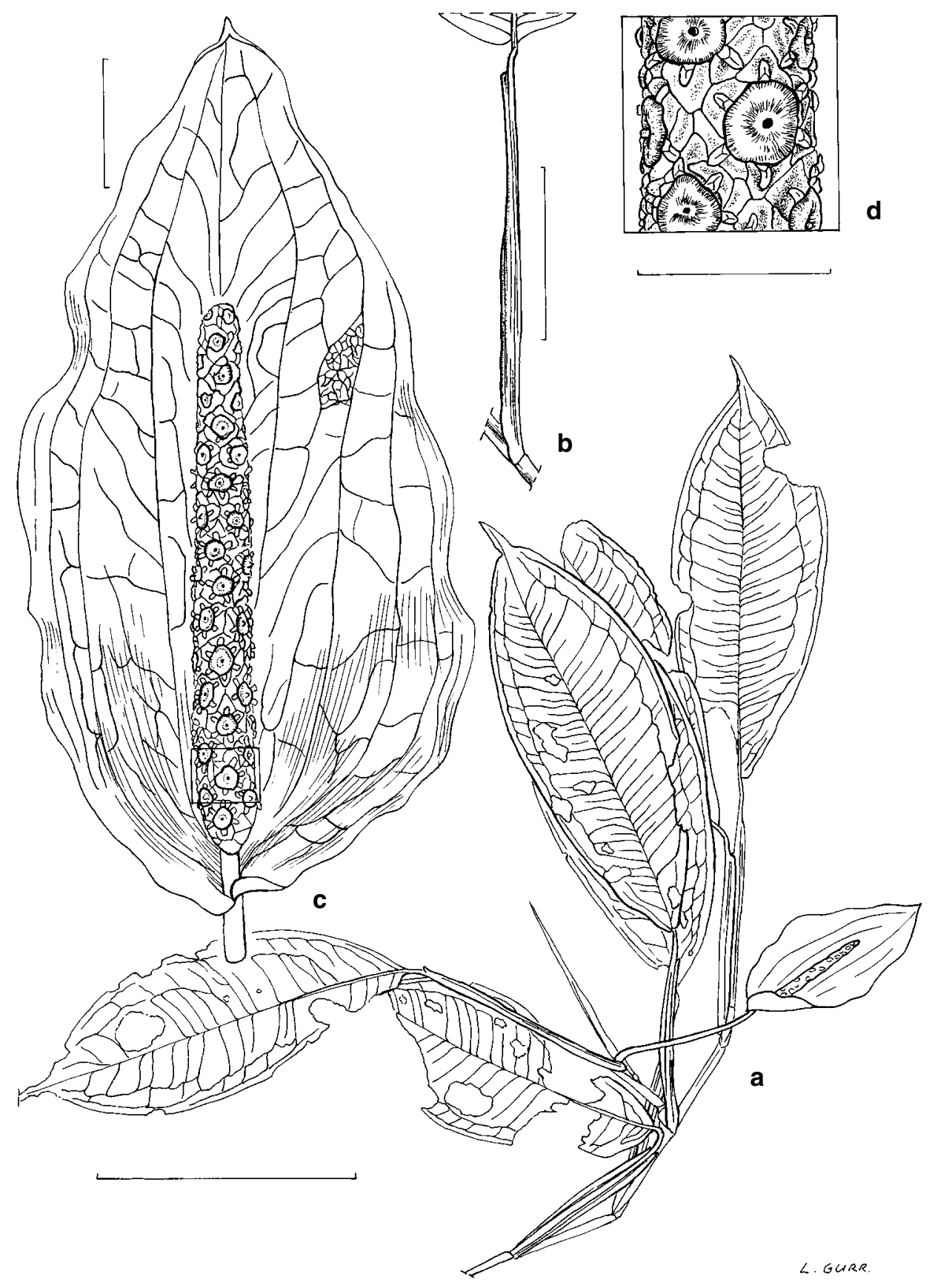

Fig. 27. Pothos kingii. $\mathbf{a}$, fertile shoot; $\mathbf{b}$, petiole detail; $\mathbf{c}$, inflorescence; $\mathbf{d}$, spadix detail: $\mathrm{a}-\mathrm{d}$, Boyce 1222. Scale bars: $\mathrm{a}=8 \mathrm{~cm} ; \mathrm{b}=4 \mathrm{~cm} ; \mathrm{c}=1 \mathrm{~cm} ; \mathrm{d}=5 \mathrm{~mm}$. 


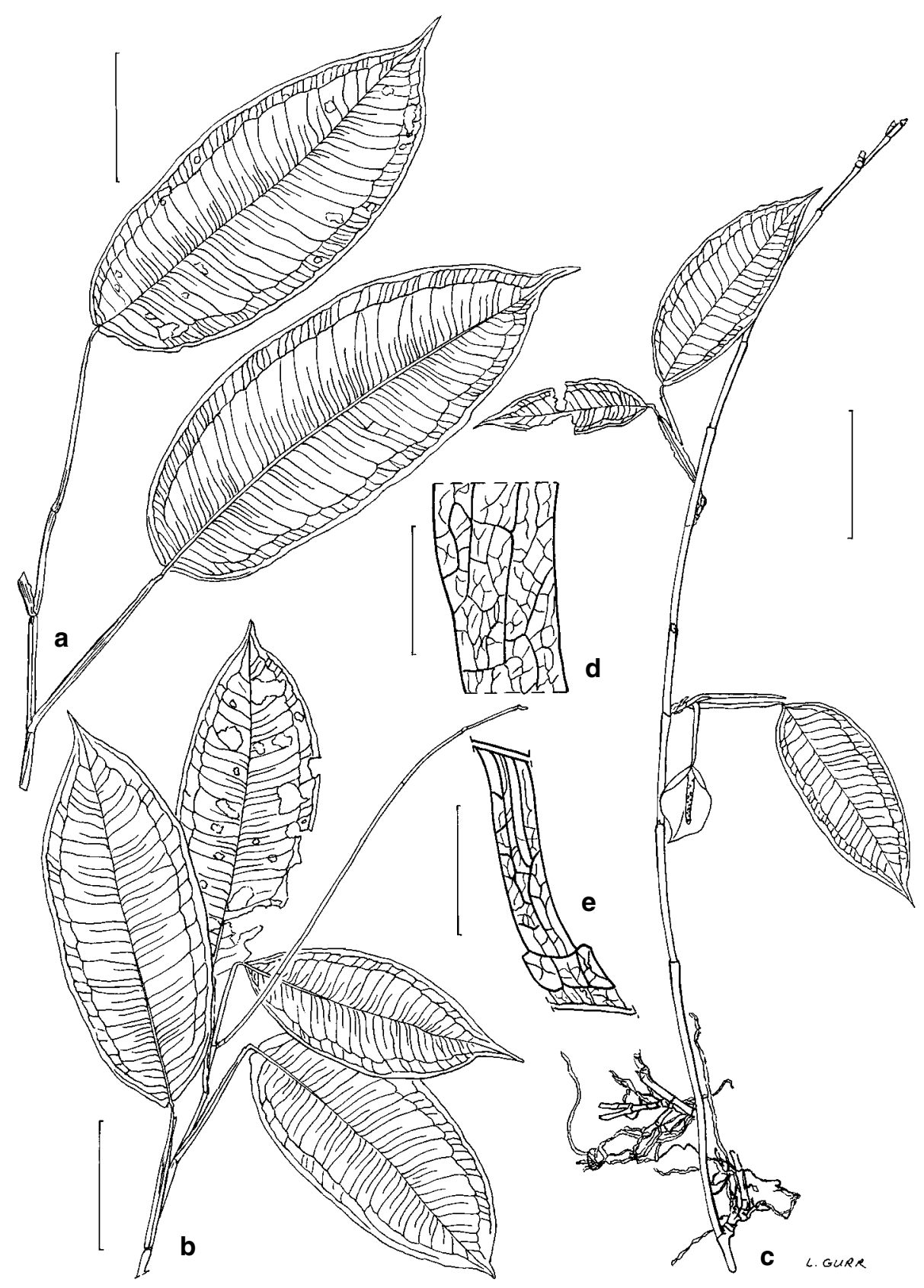

Fig. 28. Pothos kingii. a, mature sterile shoot; $\mathbf{b}$, lower part of foraging shoot; $\mathbf{c}$, flowering shoot arising directly from mature sterile shoot; $\mathbf{d}$, venation detail; $\mathbf{e}$, venation detail with midrib and intermarginal vein: a-e, Boyce 1222. Scale bars: $\mathrm{a}=6 \mathrm{~cm} ; \mathrm{b}, \mathrm{c}=8 \mathrm{~cm} ; \mathrm{d}=1.5 \mathrm{~cm} ; \mathrm{e}=5 \mathrm{~mm}$. 


\section{Pothos salicifolius Ridl. ex Burkill \& Holttum}

Pothos salicifolius Ridl. ex Burkill \& Holttum, Gard. Bull. Straits Settlem. 3 (1923) 88 ('salicifolia'); Ridl., Fl. Malay Penins. 5 (1925) 130. — Type: Malaysia, Pahang, Fraser's Hill, near Selangor border, 24 Sep 1922, Burkill \& Holttum FMS 7827 (SING, holo).

[Pothos melaleucoides Furtado, nom. ined. in sched.]

Slender to rather stout, (heterophyllous?), root-climbing liane to c. $8 \mathrm{~m}$ high. Shoot system rather weakly differentiated into flowering and non-flowering branches, terminal portions tending to be prominently zig-zagging; eocaul \& seedling not observed. Leaves stiffly coriaceous, drying dull dark greenish or brown, abaxial surface yellowish to orange-yellow; petiole $2-3 \mathrm{~cm}$ long, relatively stout, shallow-canaliculate, stoutly geniculate, especially on larger leaves, sheath not prominent, extending to just below geniculum, basally clasping, apically briefly ligulate, soon falling to leave a conspicuous wide scar, especially on larger leaves; blade $8.5-25 \times 0.7-3 \mathrm{~cm}$, very narrow elongate lanceolate-elliptic, base obtuse to subtruncate, apex acute to longacuminate, apiculate; primary lateral veins arising at $30-45^{\circ}$, very prominent, intramarginal veins prominent, 2 per side of the midrib, the entire abaxial surface notably raised-reticulate veined. Inflorescence solitary on very abbreviated foliageleafless shoots arising from below mid-and distal leaves on leafy shoots; peduncle 7-9 $\times$ c. $0.1 \mathrm{~cm}$, arching. Spathe $3.5-5 \times 0.85-1 \mathrm{~cm}$, lanceolate, spreading, conspicuously veined, base slightly clasping peduncle, apex acute to mucronate, dark purple. Spadix briefly stipitate; stipe 1-2 mm long; fertile portion $2-3.5 \times$ c. $0.2 \mathrm{~cm}$, cylindrical, straight to very slightly curved, yellow. Flowers c. $1.2 \mathrm{~mm}$ diam.; tepals 6, free; stamens 6 . Infructescence with rather few berries; fruit 9-10 $\times 4-6 \mathrm{~mm}$, globose, ripening deep scarlet; seeds not observed. - Fig. 29.

Distribution - Malesia: endemic to Peninsular Malaysia (Pahang and Negeri Sembilan).

Habitat - Upper hill to lower montane forest, 820-1230 m altitude.

Note - Unmistakable by virtue of the long, narrow leaves with very prominent abaxial surface reticulate venation; similar leaves occur in no other species of Pothos.

Other specimens examined: PENINSULAR MALAYSIA: Pahang, top of Fraser's Hill, beyond Red Cross cottage, Nicolson 1174 (B, K, L, SING, US); Negeri Sembilan, Sg. Angri, near bungalow, Nur SFN 11663 (A, BM, BO, K, KEP, SING); Pahang, Fraser's Hill, Pine Tree Hill trail, Stone 14025 (KLU, L, MO, SING).

\section{Pothos brevivaginatus Alderw.}

Pothos brevivaginatus Alderw., Bull. Jard. Bot. Buitenzorg, III, 1 (1920) 381. - Type: Indonesia, Sumatera, W Sumatera, G. Talamau, 9 May 1917, Bünnemeijer 651 (BO, holo).

Pothos longipedunculatus Ridl., Kew Bull. 1925 (1925) 93, nom. illeg., non Engl. (1905), syn. nov. - Type: Indonesia. Sumatera, Bengkulu ('Bencoolen'), Brooks s.n. (K, holo).

Somewhat robust, heterophyllous(?), root-climbing liane. Shoot system architecture not fully known, but flowering shoots free and lateral; eocaul and seedling not observed. Leaves very stiffly chartaceous, drying orange-brown; petiole $1-4 \times 0.2-0.25 \mathrm{~cm}$, rather stout, 'D' shaped in cross-section, sheath barely prominent, extending $\mathrm{c} .1 \mathrm{~cm}$ along petiole, soon falling; blade $12-28 \times 4-7 \mathrm{~cm}$, lanceolate to slightly oblanceolate, base, apex abruptly cuspidate-attenuate, mucronate; primary lateral veins prominent, arising at $70-80^{\circ}$, intramarginal veins 2 per side, the outer intramarginal vein remaining very close and parallel to margin, higher order venation prominently reticulate. Inflorescence solitary, usually subtended by cataphylls on condensed short shoots arising from below the axils of distal leaves, held inverted beneath the shoot by reflexing of the peduncle; peduncle $12-45 \times 0.1-0.15 \mathrm{~cm}$, slender, reflexed $90^{\circ}$ at the 


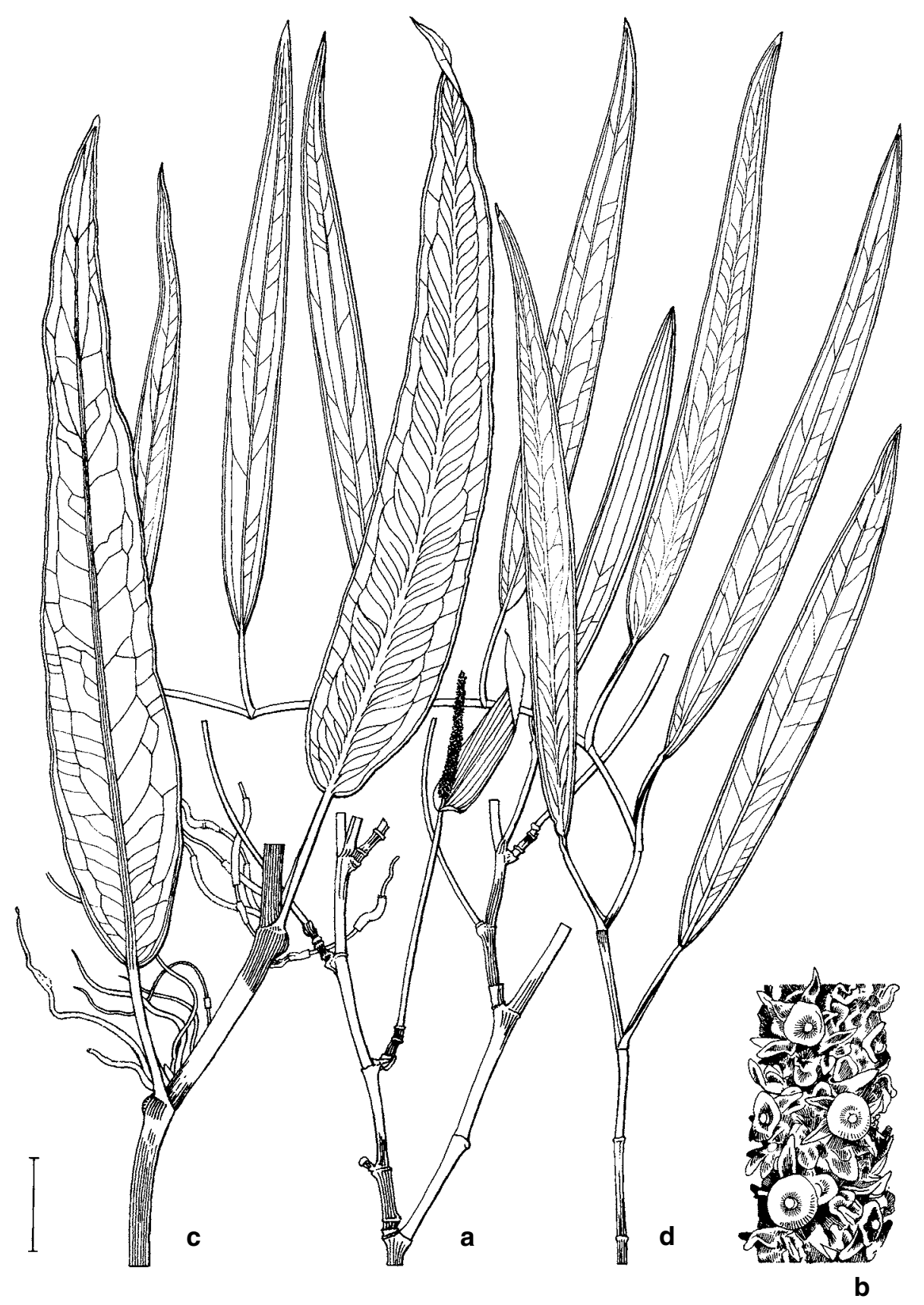

Fig. 29. Pothos salicifolius. $\mathbf{a}$, fertile shoot; $\mathbf{b}$, spadix detail; $\mathbf{c}$, adult adherent shoot; $\mathbf{d}$, juvenile sterile shoot: a-b, Nur SFN 11663; c, Nicolson 1174; d, Stone 14025. Scale bar: a, c, d = 2 cm; b = $1.7 \mathrm{~mm}$. 


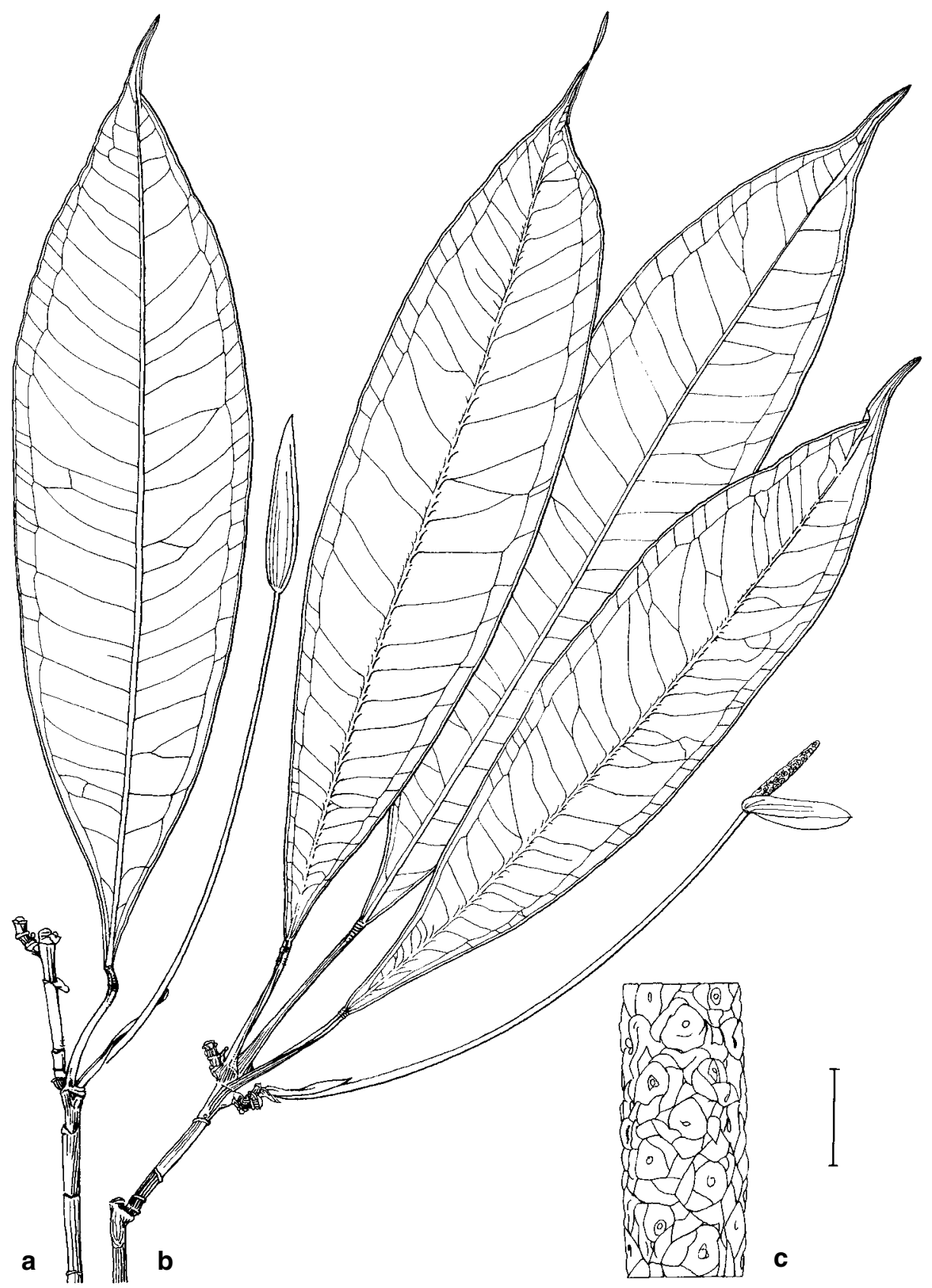

Fig. 30. Pothos brevivaginatus. a, b, fertile shoots; $\mathbf{c}$, spadix detail: $\mathbf{a}-\mathbf{c}$, Brooks s.n. Scale bar: $\mathbf{a}, \mathbf{b}=2 \mathrm{~cm}$; c $=2.2 \mathrm{~mm}$. 
base, dark purple-green. Spathe 2.5-12.5 × 0.6-4 cm, triangular-lanceolate, spreading, base clasping the peduncle, apex acute, briefly apiculate, dull greyish-green, chartaceous. Spadix briefly (c. $1 \mathrm{~mm})$ stipitate, $(2.5-) 6-7.6 \times 0.3-0.6 \mathrm{~cm}$, cylindrical to tapering-cylindrical, pale green. Flowers c. $1 \mathrm{~mm}$ diam., with 6 free tepals and 6 stamens. Infructescence not observed. - Fig. 30.

Distribution - Malesia: endemic to SW Sumatera.

Habitat - Upper hill forest, $980 \mathrm{~m}$ altitude.

Notes - Unmistakable by the extremely long peduncle, rather small spathe and the notably raised-reticulate venation on the abaxial leaf surface. The plant is slightly reminiscent of $P$. salicifolius (Peninsular Malaysia), but readily distinguished by the much wider leaf blade and considerably longer, deflexed peduncle.

The type of Ridley's illegitimate P. longipedunculatus is an excellent match for the type of Alderwerelt's earlier P. brevivaginatus.

\section{Pothos wallichii Hook. f.}

Pothos wallichii Hook.f., Fl. Brit. Ind. 6 (1893) 553; Engl. in Engl., Pflanzenr. 21 (IV.23B) (1905) 41; Engl. in Engl., Pflanzenr. 21 (IV.23B) (1905) 41; Merr., J. Straits Branch Roy. Asiat. Soc., special ed. (1921) 87. - Pothos barberianus Schott var. wallichii (Hook.f.) Ridl., Mat. Fl. Malay Penins. 3 (1907) 49 \& Fl. Malay Penins. 5 (1925) 129. - Type: Penang, Porter sub Wallich Cat. No. 4439B (K-WAL, lecto selected here; isolecto BM, K).

Slender, (heterophyllous?), root-climbing liane. Shoot system rather weakly differentiated into flowering and non-flowering branches; eocaul and seedling not observed. Leaves stiffly but thinly chartaceous, drying dull greenish; petiole $6-9 \mathrm{~cm}$ long, slender, sheath margins inrolled and thus sheath not prominent, extending to just below geniculum, basally clasping, apically briefly ligulate; blade $6-16 \times 2-5 \mathrm{~cm}$, lanceolate to lanceolate-elliptic, base acute to obtuse, apex acute to acuminate, very briefly apiculate; primary lateral veins arising at c. $80^{\circ}$, very fine, intramarginal veins 2 per side of the midrib, the lowermost arising from the base, the next arising from the lowest part of the midrib, outer intramarginal vein remaining very close and parallel to margin, inner vein c. $4 \mathrm{~mm}$ distant, both reaching the leaf tip. Inflorescence solitary from tips of leafy shoots; peduncle (4-)8-11 × c. $0.1 \mathrm{~cm}$, arching, very rarely reflexed. Spathe 4-5 $\times$ 0.5-1 cm, lorate, spreading to weakly reflexing, base auriculate, auricle margins inrolled, barely decurrent on the peduncle, apex acute to acuminate. Spadix briefly stipitate; stipe c. $2 \mathrm{~mm}$ long; fertile portion (5-)6-7.5 × c. $0.2 \mathrm{~cm}$, slender, cylindrical, straight to slightly curved, base unequal, slightly cochleate, creamyyellow. Flowers c. $1.2 \mathrm{~mm}$ diam.; tepals 6, free; stamens 6. Infructescence with rather few berries, these mostly carried on the basal half of spadix; fruit 9-12 $\times 4-5 \mathrm{~mm}$, ellipsoid with a prominent stigmatic remnant, ripening deep scarlet; seeds not observed. - Fig. 31.

Distribution - Malesia: Peninsular Malaysia, Java, Borneo. Probably more common than indicated by the few collections seen.

Habitat - Upper hill forest, $900 \mathrm{~m}$ altitude (only recorded from one specimen).

Notes - Pothos wallichii is immediately recognizable by the very long and slender inflorescences, arching from leafy shoot tips. It is most similar to $P$. volans but readily distinguished by the much longer stipitate spadix and the narrower spathe.

Hooker cited three syntypes in describing $P$. wallichii. They are conspecific and we have selected the most complete as lectotype. The other syntypes are: Perak, Scortechini 621 (K) and Perak, Wallich 4439A (K-WAL).

Other specimens examined: PENINSULAR MALAYSIA: Perak, Hermitage, Curtis 1327 (K, SING); Johor, G. Pulai, Nur \& Kiah 7780 (SING); Perak, Scortechini 621 (K); Perak, Scortechini 621A (BM, 


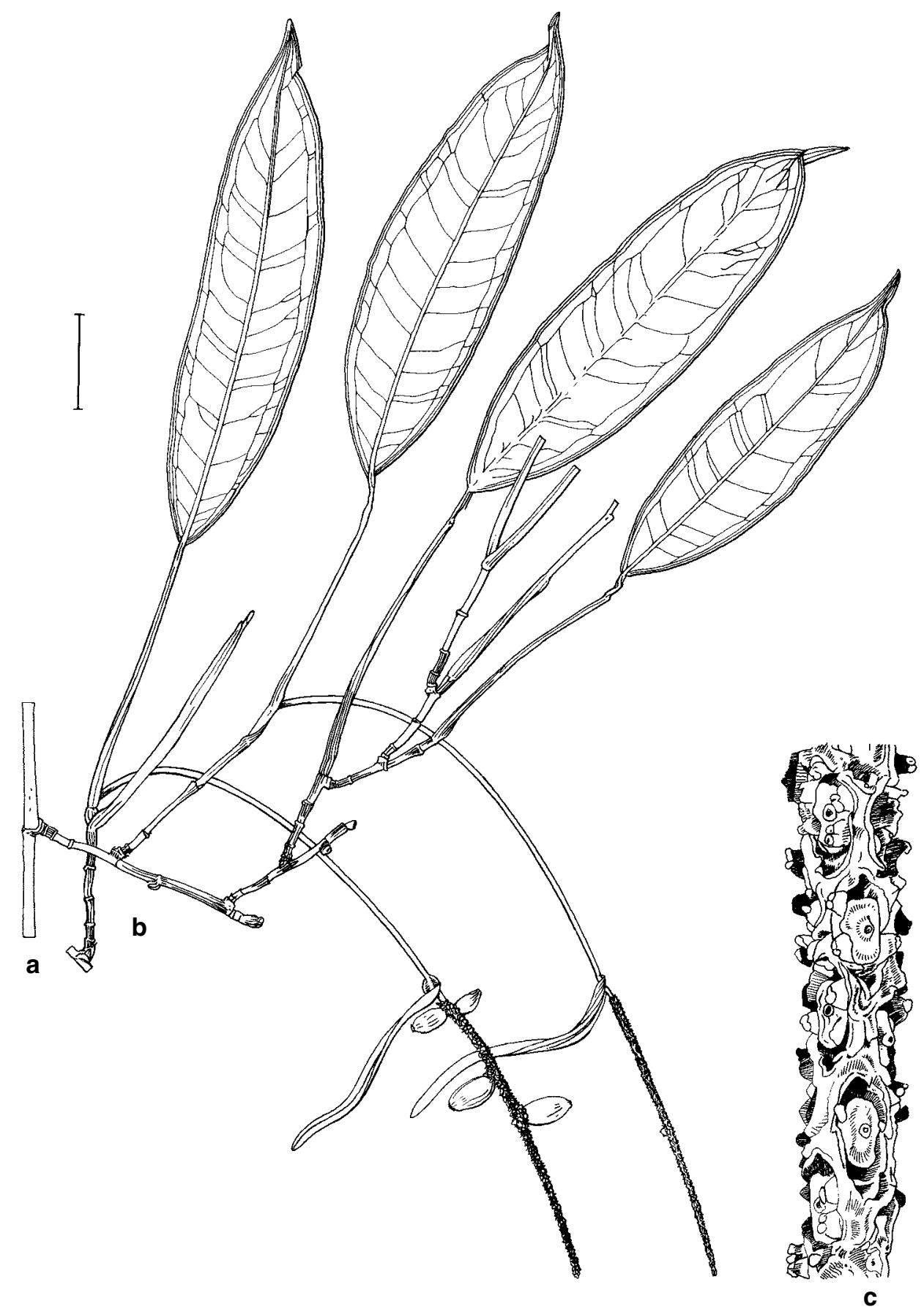

Fig. 31. Pothos wallichii. a, fertile shoot in flower; $\mathbf{b}$, fertile shoot in fruit; $\mathbf{c}$, spadix detail: a-c, Clemens $\mathcal{E}$ Clemens 20017. Scale bar: $\mathrm{a}, \mathrm{b}=2 \mathrm{~cm} ; \mathrm{c}=1.7 \mathrm{~mm}$. 
SING); Perak, Wallich 4439A (K-WAL). JAVA. W Java, Udjung Kulon Reserve, Mt Pajung, Kostermans sub UNESCO 192 (A, BO, K, L). SARAWAK. 1st Div., G. Pueh (Mt Poi), Clemens \& Clemens 20017 (A, BO, K, MO). KALIMANTAN. Korthals s.n. (BO, K, L, P).

\section{Pothos volans P.C. Boyce \& A. Hay, sp. nov.}

Pothos wallichii propinquus est, sed ab eo spadice multo breviore spatha latiore differt. A P. lancifolio pedunculo multo tenuiore arcuato (no basi flexo) distinguitur. Ab ambitis speciebus habitus manifeste anfractuosus surculorum liberorum lateralium florentium distinctus est. - Type: Brunei Darussalam, Temburong, Amo, Ulu Belalong, L.P. 382, ridge W of campsite, 22 Jan 1994, J. Dransfield 7419 (K, holo; iso BRUN).

Slender, heterophyllous(?), root-climbing liane. Shoot system well differentiated into free lateral prominently zig-zagging flowering and adherent non-flowering shoots; eocaul and seedling not observed. Leaves deep green adaxially, slightly paler abaxially, chartaceous, drying yellow to greyish green with the midrib pale yellow and raised abaxially; petiole $1-3 \times 0.1-0.25 \mathrm{~cm}$, slender, sheath rather prominent, extending to base of geniculum, clasping basally, minutely ligulate apically; blade $2.5-15.5 \times 1-4.5 \mathrm{~cm}$, narrowly elliptic or lanceolate, occasionally weakly oblique, base subacute to obtuse, apex attenuate-mucronate, acute or attenuate, minutely apiculate; primary lateral veins arising $75-85^{\circ}$, intramarginal veins 2 per side, the outer intramarginal vein remaining very close and parallel to margin. Inflorescence solitary, terminal on leafy shoots, held arching from the tip of the shoot; peduncle $6-7 \times 0.05-0.1 \mathrm{~cm}$, very slender, arching, pale green. Spathe 4-5 × 0.9-1.5 cm, broadly ovate-triangularlanceolate, erect and covering spadix, base clasping peduncle, apex acuminate, apiculate, pale green, thinly papery. Spadix sessile, $2-3 \times 0.15-0.25 \mathrm{~cm}$, slender cylindrical, yellow-green. Flowers c. $1.1 \mathrm{~mm}$ diam., with 6 free tepals and 6 stamens. Infructescence with few berries; fruits 7-10 $\times 4-6 \mathrm{~mm}$, ellipsoid; seeds not observed. Fig. 32.

Distribution - Malesia: endemic to Borneo (Sarawak and Brunei Darussalam).

Habitat - Ridgetop hill to upper hill kerangas, at 760-820 m altitude.

Note - Similar to $P$. wallichii but differing by the much shorter sessile spadix and broader spathe. It is distinguished from $P$. lancifolius by the much more slender, arching (not basally bent) peduncle. The prominent zig-zagging of the free lateral flowering shoots is distinctively different from either species.

Other specimens examined: BORNEO: SARAWAK: 1st Div., Tebakang area, summit of Bk. Alak, Awa \& Paie $S 45642$ (K, KEP, L, SAN, SAR, US). BRUNEI DARUSSALAM: Temburong, Amo, Bk. Belalong, J. Dransfield 7169 A (BRUN, K). Temburong, Amo, Bk Belalong, ridge to false summit, K.M. Wong 1488 (BRUN, K).

\section{Pothos mirabilis Merr.}

Pothos mirabilis Merr., Philipp. J. Sci. 21 (1922) 516. - Type: Malaysia, Sabah, Lubuk and Sugut Distr., Sumawang River valley, 21 Sep 1918, Agama BS 664 (US, lecto selected here; isolecto K, P, UCL; A (photo of destroyed PNH sheet)). Merrill cites three syntypes; that chosen as lectotype is the only fertile collection; the US duplicate is in the best condition. The other syntypes are: Malaysia, Sabah, Batu Lima, Ramos 1260 and Malaysia, Sabah, Sandakan, Myburgh, Elmer 20364. The K specimen is the only duplicate of the Ramos collection traced, and is sterile. All located duplicates of the widely distributed Elmer 20364 are sterile.

Rather slender, heterophyllous(?), root-climbing liane. Shoot system architecture not fully known, but flowering shoots free and lateral; eocaul and seedling not observed. Leaves chartaceous, drying yellowish green with the apical geniculum almost black; petiole $4-12 \times 0.25-0.4 \mathrm{~cm}$, stout, sheath prominent, extending to base of geniculum 


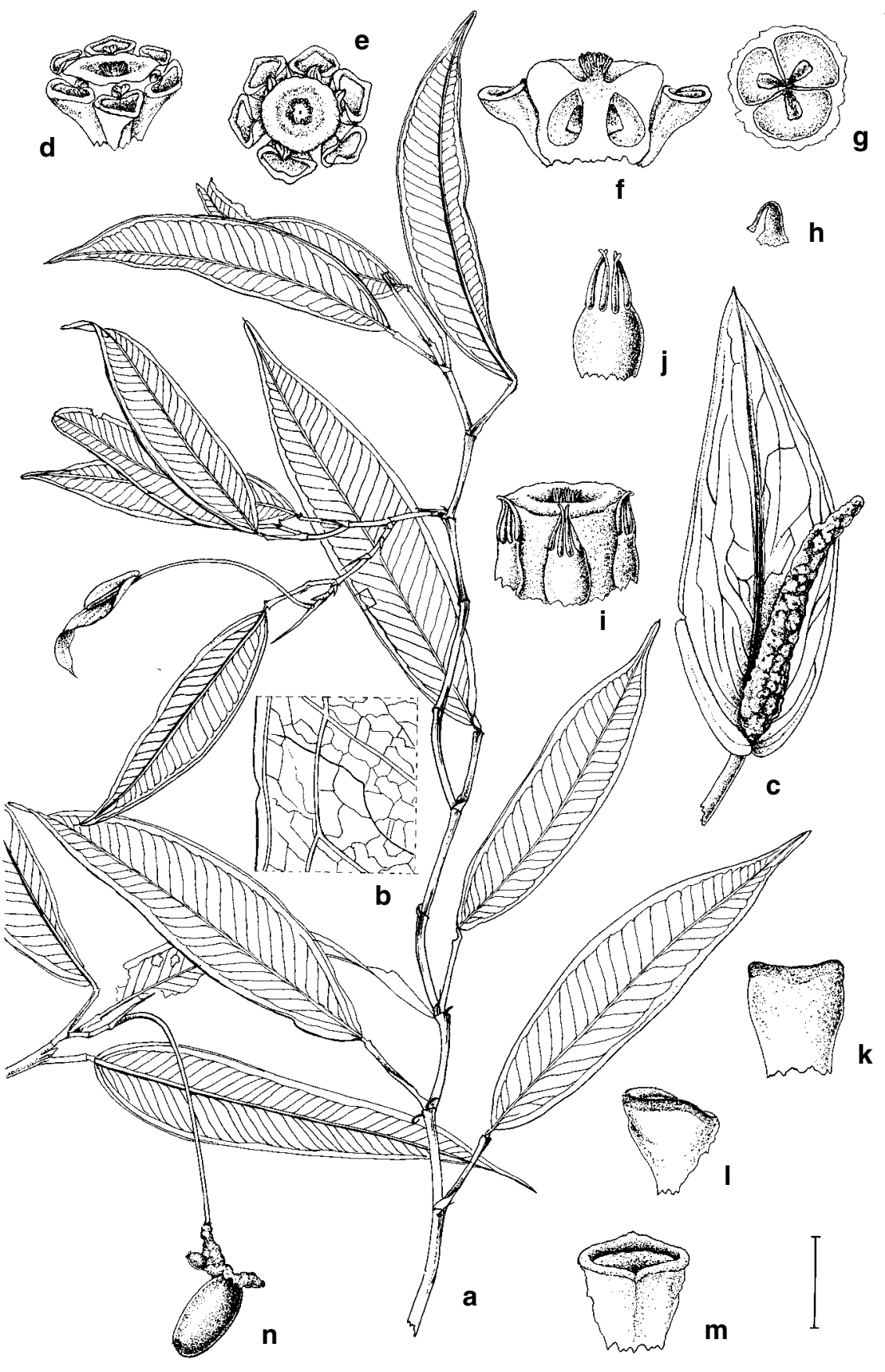

Fig. 32. Pothos volans. $\mathbf{a}$, fertile shoot in flower; $\mathbf{b}$, venation detail; $\mathbf{c}$, inflorescence; $\mathbf{d}$, whole flower, three quarter view; e, whole flower, top view; f, whole flower, longitudinal section; g, ovary, transverse section; $\mathbf{h}$, embryo, side view; $\mathbf{i}$, flower, tepals removed, three quarter view; $\mathbf{j}$, single stamen, external view; $\mathbf{k}$, tepal, external view; $\mathbf{l}$, tepal, side view; $\mathbf{m}$, tepal, external inside view; $\mathbf{n}$, infructescence: $\mathrm{a}-\mathrm{n}$, Dransfield 7419. Scale bar: $\mathrm{a}=3 \mathrm{~cm} ; \mathrm{b}=2 \mathrm{~mm} ; \mathrm{c}=1 \mathrm{~cm} ; \mathrm{d}, \mathrm{e}=0.7 \mathrm{~mm} ; \mathrm{f}=0.4 \mathrm{~mm}$; $\mathrm{g}=0.6 \mathrm{~mm} ; \mathrm{h}=1 \mathrm{~mm} ; \mathrm{i}=0.6 \mathrm{~mm} ; \mathrm{j}=0.5 \mathrm{~mm} ; \mathrm{k}-\mathrm{m}=0.7 \mathrm{~mm} ; \mathrm{n}=1 \mathrm{~cm}$. 


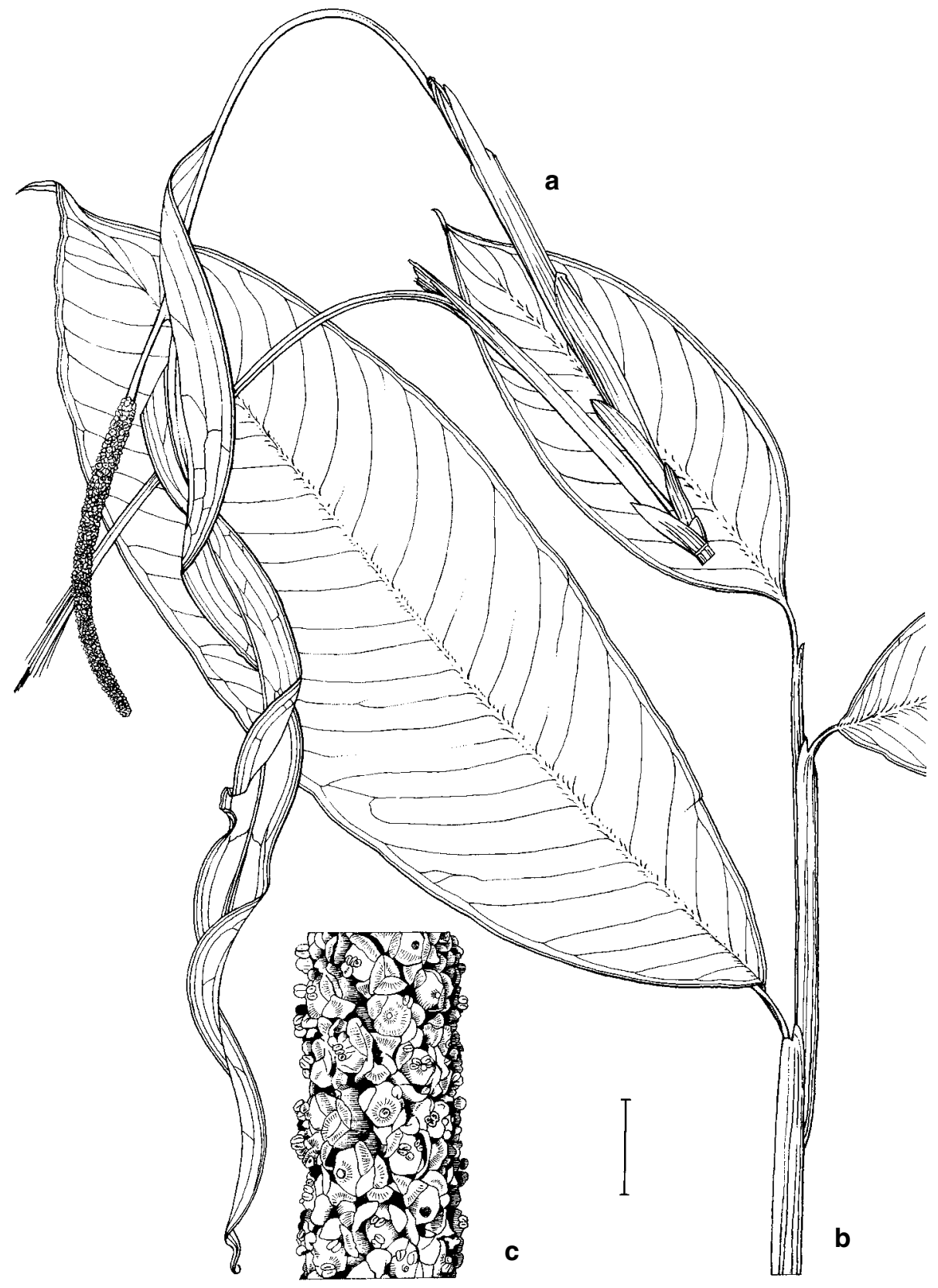

Fig. 33. Pothos mirabilis. a, fertile shoot; b, adult sterile shoot; c, spadix detail: a-c, Agama BS 664 . Scale bar: $\mathrm{a}, \mathrm{b}=2 \mathrm{~cm} ; \mathrm{c}=2.7 \mathrm{~mm}$. 


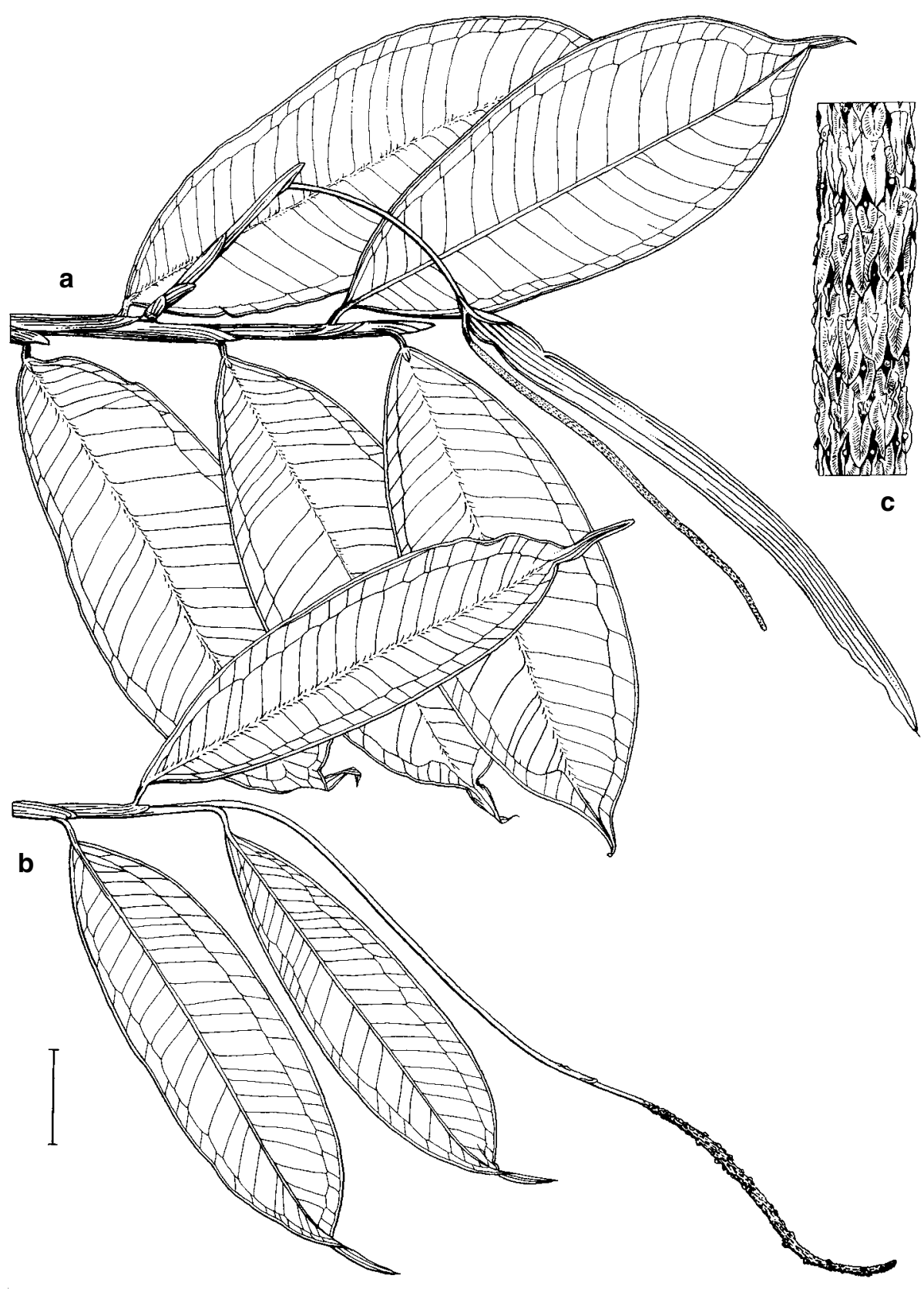

Fig. 34. Pothos mirabilis. a, fertile shoot; $\mathbf{b}$, fertile shoot, early stages of infructescence; $\mathbf{c}$, spadix detail: a \& c, Moulton's native collector 11; b, 'Native collector' 1479 . Scale bar: a, b $=2 \mathrm{~cm}$; c $=2.2 \mathrm{~mm}$. 
and overtopping it by two prominent ligules, clasping the shoot for almost its entire length; blade 12-28 × 3-9.5 cm, elliptic to oblong-elliptic or falcate-lanceolate, somewhat oblique, base subacute, apex acute to attenuate-mucronate, falcate, minutely apiculate; primary lateral veins arising $75-80^{\circ}$, intramarginal veins 2 per side, the outer intramarginal vein remaining close and parallel to margin. Inflorescence solitary, terminal on leafy shoots, held arching from the tip of the shoot, very rarely produced from foliage-leafless shoots arising from otherwise leafy shoots; peduncle 6-17 $\times 0.05-0.15 \mathrm{~cm}$, slender, very long and curving, dark purple-green. Spathe extremely elongate, $19-37 \times 1-2 \mathrm{~cm}$, very narrowly ovate, drooping and twisting into two or more graceful elongate spirals, base long-decurrent for up to $5 \mathrm{~cm}$ on peduncle, apex long acuminate, dark purple with paler longitudinal reticulations, drying very thin and somewhat shiny, degrading with fruiting and persisting as diaphanous netted tissue. Spadix stipitate; stipe $1-2.5 \times$ c. $0.1 \mathrm{~cm}$, very slender; fertile portion $(6-) 12-14 \times$ c. $0.3 \mathrm{~cm}$, very slender curving cylindrical, dark greyish purple. Flowers c. $1.6 \mathrm{~mm}$ diam., with 6 free tepals and 6 stamens. Infructescence with few berries; fruits 7-10 ×3.5-6 mm, oblong-ellipsoid; seeds not observed. - Fig. 33, 34 .

Distribution - Malesia: endemic to Borneo.

Habitat - Lowland forest on yellow sandy loam, 20-300 m altitude.

Note - A species of extraordinary appearance in flower and unmistakable by the enormously elongated and twisted pendent spathe. The inflorescences are mostly produced from the tips of leafy shoots and this together with the long slender peduncle would seem to ally P. mirabilis with, e.g. P. volans and P. wallichii, from which it may be distinguished by the considerably greater stature of the plant, the longstipitate spadix and the aforementioned spathe.

Ridley's Pothos longus (which has priority) may belong here. See below under 'Insufficiently known species'.

Other specimens examined: BORNEO: SABAH: Sandakan, Ulu Sg. Olgan, below B. Panandawan, Labuk Sugut, Aban et al. SAN 66890 (K, SAN); Sandakan, Myburgh, Elmer 20364 (A, C, K, MO, NSW, P, SING, UCL); Tawau, Luasong camp, Madani SAN 107943 (SAN); Beaufort, Montineor road, mile 12, Kg. Bambangan, Madius SAN 49253 (K, SAN); No further data , Moulton's native collector 11 (BM); No further data, 'Native collector' 1479 (K, US); Batu Lima, Ramos 1260 (K). KALIMANTAN: E Kalimantan, central Kutei, Gelajan River, G. Kelopok, near Tabang, Kostermans 10536 (BO, L).

\section{Pothos oxyphyllus Miq.}

Pothos oxyphyllus Miq., Bot. Zeit. 14 (15 Aug. 1856) 561 \& Fl. Ned. Ind. 3 (25 Dec 1856) 181, t.38 ('oxyphylla'); Schott, Prodr. Syst. Aroid. (1860) 559-560; Engl. in A. \& C. DC, Monogr. Phan. 2 (1879) 89 \& in Engl., Pflanzenr. 21 (IV.23B) (1905) 37; Koorders, Exkursfl. Java, 1 (1911) 251; Backer \& Bakh.f., Fl. Java, 3 (1968) 103. — Type: Indonesia, W Java, G. Salak, Teysmann s.n. (L, holo).

Pothos sumatranus Miq., Fl. Ned. Ind., Eerste Bijv. (1861) 596; Engl. in A. \& C. DC, Monogr. Phan. 2 (1879) 94 syn. nov. - Type: Indonesia, Sumatera Barat, near Lubualang, Teysmann s.n. (BO, holo; iso L).

Pothos korthalsianus Schott, Ann. Mus. Bot. Lugd.-Bat. 1 (1864) 284, syn. nov. - Type: Indonesia, Sumatera, Korthals s.n. (L, holo).

Pothos inaequalis Ridl., J. Straits Branch Roy. Asiat. Soc. 41 (1904) 47, syn. nov. - Type: Malaysia, Pahang, Palau Tawas, 20 Aug 1891, Ridley 2391 (SING, holo; iso BM, K).

Pothos jacobsonii Alderw., Bull. Jard. Bot. Buitenzorg, III, 1 (1920) 380, syn. nov. - Type: Indonesia, Sumatera, Bengkulu, G. Dempo, Aug 1916, Ajoeb 486 (BO, holo). 
Slender, homeophyllous, diffuse-branched root-climbing liane. Shoot system rather poorly differentiated into adherent, non-flowering and free lateral flowering branches, usually with considerable flagellate shoot growth; flowering shoot abbreviated, arising from below the leaf axil of a fully developed leaf, or from an older naked portion of stem, leafless except for subtending foliage leaf, with several small cataphylls; eocaul not observed; seedling shingle-leaved, then abruptly producing adult leaves. Leaves thinly chartaceous, drying pale brownish green; petiole $2.5-3 \mathrm{~cm}$ long, slender, often sheathing stem with just the geniculum and blade spreading; sheath rather prominent, reaching to just below geniculum and extending by two very small ligules; blade $6-25 \times 2-8 \mathrm{~cm}$, oblong-elliptic to oblong-lanceolate, very slightly falcate, unequal, occasionally quite strongly so, base subacute to minutely truncate, apex falcate, acuminate to stoutly long-attenuate, briefly minutely apiculate; primary lateral veins arising at $80-90^{\circ}$, intramarginal veins 2 per side, the lowermost arising from the base, outer intramarginal vein remaining very close and parallel to margin; higher venation fine but very distinctly reticulate. Inflorescence solitary, although shoots always reiterating and thus rarely two inflorescences at different stages of maturity may be present; peduncle $1.3-5 \mathrm{~cm}$, rather slender, erect, green to purplegreen. Spathe 1.3-2.2 × 0.3-0.4 cm, oblong-ovate, reflexed, falling early in fruit development leaving only basal portion, base rounded, barely decurrent on the peduncle, apex obtuse, filamentous-mucronate, purple. Spadix sessile to very briefly stipitate; stipe 0-1.5 mm long; fertile portion $2.5-4 \times 0.2-0.4 \mathrm{~cm}$, cylindrical, straight to slightly curved, white. Flowers c. $1.5 \mathrm{~mm}$ diam., with 6 free tepals and 6 stamens. Infructescence with few berries; fruit 6-10 $\times 4-7 \mathrm{~mm}$, ellipsoid, ripening deep red; seeds not observed. - Fig. 35.

Distribution - Malesia: Sumatera, Peninsular Malaysia, Java. Much more common than the rather few collections might suggest.

Habitat - Primary to slightly disturbed lowland to hill forest, almost always on inundated soils, 25-650 $\mathrm{m}$ altitude.

Notes - Most similar to P. inequilaterus (Philippines) especially in the form and venation of the leaf blade, but readily distinguished by the larger inflorescences. It is a rather variable species, especially with regard to the number of inflorescences and their size, hence the surprisingly numerous synonyms.

Pothos oxyphyllus is almost always associated with inundated soils. At Pasoh F.R., Negeri Sembilan it occurs in extensive thickets in standing water.

Other specimens examined: PENINSULAR MALAYSIA: Selangor, Gombak, Ulu Gombak F.R., Boyce 678 (K, KEP); Perak, Matang, Bubu F.R., Compartment 76, Boyce 699 (K, KEP); Negeri Sembilan, Pasoh F.R., trail to and environs of Canopy Walkway, Boyce 1336 (K, KEP); Terengganu, Kemaman, Bk. Kajang, Corner s.n. (SING); Pahang, near Kota Glanggi, Henderson s.n. (SING); Pahang, Tembeling, Henderson s.n. (BO, SING); Johore, Ulu Kajang, Holttum SFN 10912 (K, SING); Perak, Tanjok Pondok F.R., 12 miles N of Taiping, Nicolson 1083 (US); Selangor, Bk. Pajong Kajang, Symington 24246 (K, SING). SUMATERA: Aceh, NE of Krung Luas, E of Trumon, Asdat 70 (BO); Aceh, G. Leuser N.P., Sg. Kloet, along Krung Lembang, vicinity of Pucuk Lembang, de Wilde $\mathcal{E}$ de Wilde-Duyfjes 20027 (BO, L); Sumatera Utara, Bk. Lawang, Bohorok, Langkat, Soedarsono 226 (BO), 243 (BO); No further data, B. Raja, H.F. Sun 9953 (BO). JAVA: W Java, G. Cipuli, Bakhuizen van den Brink 4216 (BO, L); W Java, G. Cibodas, Tjiampea, Bakhuizen van den Brink 5689 (BO, K, L, P); W Java, Jakarta, G. Pangar, Bakhuizen van den Brink 6122 (BO, L); W Java, G Cibodas, Tjampea, Hallier s.n. (BO); No further information, Hasskarl s.n. (L, P); E Java, Teysmann s.n. (K, L); W Java, G Cibodas, Tjampea, van Steenis 610 (BO, L).

29. Pothos inaequilaterus (C. Presl) Engl.

Pothos inaequilaterus (C. Presl) Engl. in A.\& C. D.C., Monogr. Phan. 2 (1879) 88 \& in Engl., Pflanzenr. 21 (IV.23B) (1905) 37; Merr., Enum. Philippine Pl. 1 (1922) 172. — 


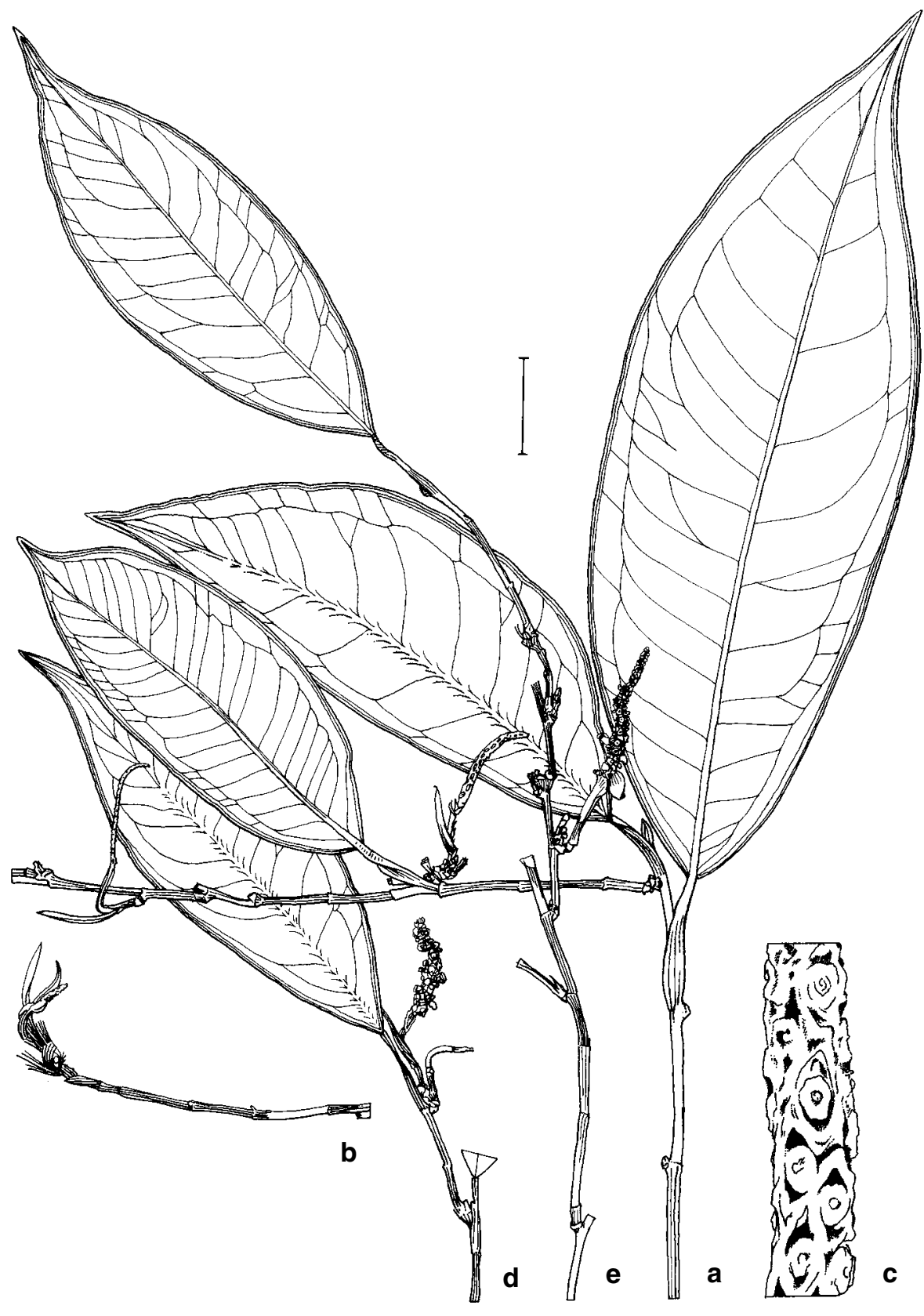

Fig. 35. Pothos oxyphyllus. a, fertile shoot; b, fertile shoot, detail; $\mathbf{c}$, spadix detail; $\mathbf{d}$, fertile shoot, early stages of infructescence; e, fertile shoot, mature infructescence: $\mathrm{a}-\mathrm{d}$, Boyce 678 . Scale bar: $\mathrm{a}, \mathrm{b}, \mathrm{d}, \mathrm{e}=2 \mathrm{~cm} ; \mathrm{c}=2.2 \mathrm{~mm}$. 
Scindapsus inaequilaterus C. Presl, Epimel. Bot. (1851) 240. - [Pothos cumingianus Schott, Oesterr. Bot. Wochenbl. 5 (1855) 19 ('cummingianus') \& Aroideae, 24 (1856-1857) t.50 \& Prodr. Syst. Aroid. (1860) 570-571, nom. superfl. pro P. inaequilaterus]. - Type: Philippines, Luzon, Albay Prov., 1841, Cuming 908 (PRG, holo; iso BM, E, G, K, L, LE, M, P).

Slender, (homeophyllous?), root-climbing liane. Shoot system rather poorly differentiated into adherent non-flowering, and free lateral flowering branches; eocaul \& seedling not observed; flowering shoot abbreviated, arising from below the leaf axil of a fully developed leaf, or from an older naked portion of stem, leafless except for subtending foliage leaf, with several well-developed cataphylls. Leaves thinly chartaceous, drying dull grey greenish; petiole $2-5 \mathrm{~cm}$ long, slender, rarely rather stout, sheath weakly prominent, extending to just below geniculum and extending above it by two small ligules; blade 10-25 ×3.5-12 cm, oblong-elliptic, slightly falcate, unequal, occasionally quite strongly so, base subacute to minutely truncate, apex prominently falcate, acuminate to attenuate, briefly apiculate; primary lateral veins arising at c. $35^{\circ}$, intramarginal veins 2 per side, the lowermost arising from the base, outer intramarginal vein remaining very close and parallel to margin, inner vein c. 1 $\mathrm{cm}$ distant, both reaching the leaf tip; higher venation fine but very distinctly reticulate. Inflorescence several together; flowering shoots always reiterating and thus several inflorescences at various stages of maturity usually present; peduncle $3-7 \mathrm{~cm}$, rather slender, erect or curving, dull green. Spathe 1-1.2 $\times 0.7-1 \mathrm{~cm}$, ovate to oblongovate, spreading to slightly reflexed, base rounded, barely decurrent on the peduncle, apex obtuse, very weakly beaked. Spadix sessile to briefly stipitate; stipe $0-2.5 \mathrm{~mm}$ long; fertile portion 1-2 $\times 0.2-0.4 \mathrm{~cm}$, cylindrical, straight to slightly curved, base rounded. Flowers c. $1.1 \mathrm{~mm}$ diam., with 6 free tepals and 6 stamens. Infructescence with few berries; fruit c. $10 \times 5 \mathrm{~mm}$, globose to ellipsoid, ripening deep scarlet; seeds not observed. - Fig. 36.

Distribution - Malesia: endemic to and widespread in the Philippines.

Habitat — Secondary forest, 400-900 m altitude.

Note - Unmistakable by the clusters of small inflorescences and the prominently reticulate higher venation. In blade shape and venation $P$. inequilaterus is most similar to P. oxyphyllus (Sumatera, Peninsular Malaysia, Java) and there has been much confusion between them in herbaria and literature, especially with regard to synonymy; all the above synonyms have been until recently associated with $P$. oxyphyllus. Nevertheless, $P$. inaequilaterus is readily distinguished from $P$. oxyphyllus by its smaller, clustered inflorescences.

Other specimens examined: PHILIPPINES: Luzon, Quezon N.P., Croat 53004 (MO); Luzon, Camarines Norte, Balu, Bicol N.P., Mabesa 836 (A); Mindanao, Agusan Prov., Tangao So., San Mateo Bo., Butuan, Mendoza PNH 41913 (SING); Mindanao, Surigao Prov., Mt Kabatuan, Mendoza E Convocar PNH 10533 (PNH, SING); Mindanao, Davao Prov., Compostela, Maparat Barrio, 70 km NE of Davao, Nicolson 708 (K, PNH, US); Samar, Loquilocan Barrio, Nicolson 808 (US); Samar, Catubig River, Ramos BS 24474 (A, BO, K, MO, P, SING, US); Mindanao, Agusan, Tungao logging camp, Villan PNH 98071 (PNH); Leyte, Wenzel 357 (A, BM, MO, US); Surigao, Wenzel 3056 (A, BO, $\mathrm{K}, \mathrm{MO}$ ).

\section{Pothos brevistylus Engl.}

Pothos brevistylus Engl. Bull. Soc. Tosc. Ortic. 4 (1879) 267; Engl. in Beccari, Malesia 1 (1883 ('1882') t. 16, f. 10-13; Engl. in Engl. Pflanzenr. 21 (IV.23B) (1905) 37-38 ('brevistilus'); Ridl., J. Straits Branch Roy. Asiat. Soc. 44 (1905) 188; Merr., J. Straits Branch Roy. Asiat. Soc., special ed. (1921) 86. - Type: Malaysia, Sarawak, 1st Div., Kuching, Nov 1871 Beccari p.b. 3984 (FI, holo; iso B, K). 


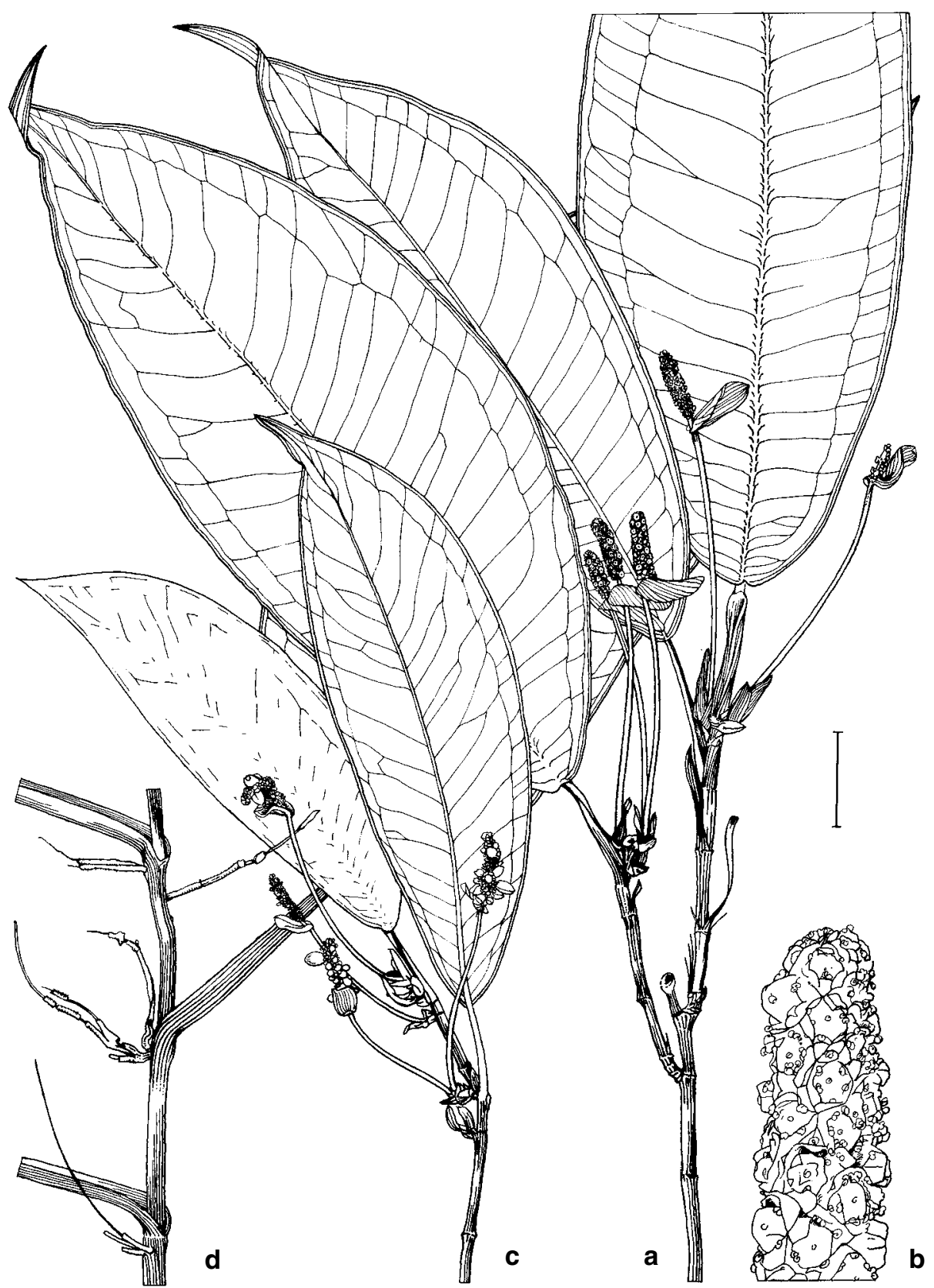

Fig. 36. Pothos inaequilaterus. $\mathbf{a}$, fertile shoot; $\mathbf{b}$, spadix detail; $\mathbf{c}$, fertile shoot, early and mature stages of infructescences; d, adherent mature shoot detail: a-b, Wenzel 357; c, Mabesa 836; d, Croat 53004. Scale bar: $\mathbf{a}, \mathbf{c}, \mathbf{d}=2 \mathrm{~cm} ; \mathbf{b}=3.3 \mathrm{~mm}$. 


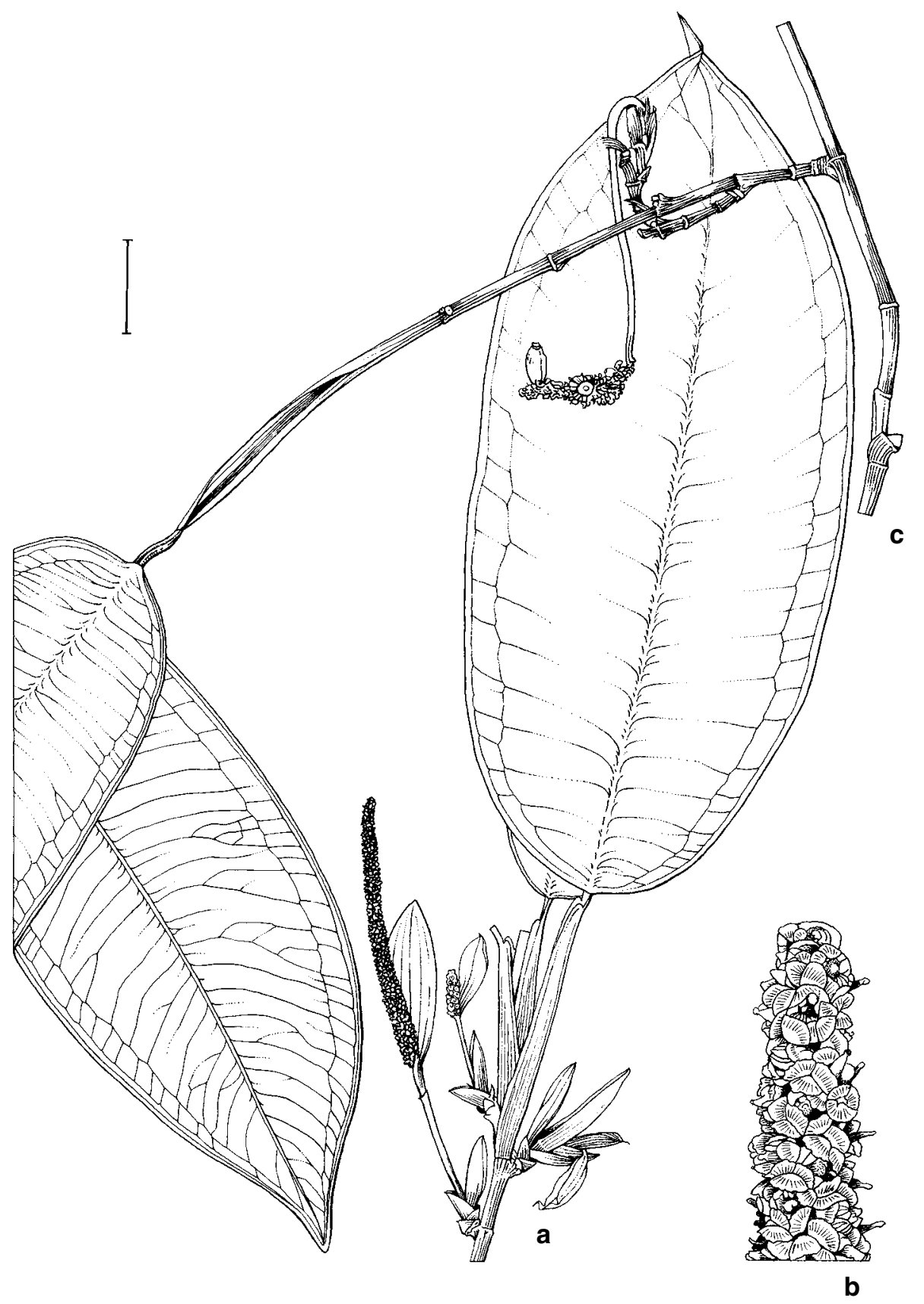

Fig. 37. Pothos brevistylus. a, fertile shoot; $\mathbf{b}$, spadix detail; $\mathbf{c}$, fertile shoot, mature stage of infructescence: $\mathrm{a}-\mathrm{b}$, Hose 582; c, Beaman 8463. Scale bar: $\mathrm{a}, \mathrm{c}=2 \mathrm{~cm} ; \mathrm{b}=3.3 \mathrm{~mm}$. 
Pothos hosei Rendle, J. Bot. 39 (1901) 178; Engl. in Engl., Pflanzenr. 21 (IV.23B) (1905) 38; Merr., J. Straits Branch Roy. Asiat. Soc., special ed. (1921) 87. — Type: Malaysia, Sarawak, 5th Div., Baram, Marudi, Apr 1895, Hose 582 (BM, holo; iso K).

Slender to somewhat robust, heterophyllous (?), root-climbing liane. Shoot system only weakly differentiated into flowering and non-flowering branches; eocaul and seedling not observed. Leaves mid-green adaxially, slightly paler abaxially, stiffly chartaceous, drying greyish green; petiole $2.5-12 \times 0.3-0.4 \mathrm{~cm}$, often rather stout, prominently geniculate apically, sheath extending to below the geniculum and briefly ligulate apically, clasping basally, prominent, later degrading into feeble fibres; blade 14-26 $\times$ 4-11.5 cm, narrowly to rather broadly oblong-ovate to oblong-elliptic, slightly oblique, occasionally falcate, base obtuse, rarely weakly cordate in largest examples, apex short-attenuate, minutely apiculate; primary lateral veins arising at $60-85^{\circ}$, intramarginal veins 2 per side, the outer intramarginal vein remaining very close and parallel to margin. Inflorescence solitary to few together, usually subtended by cataphylls on condensed short shoots arising from below the axils of distal leaves, occasionally from such shoots arising (persisting?) on leafless older stems, much more rarely terminal on leafy shoots, erect; peduncle $2.5-4 \times 0.1-0.15 \mathrm{~cm}$, erect, yellowgreen. Spathe $1.5-4 \times 0.25-1.4 \mathrm{~cm}$, lorate to lorate-triangular, reflexed, not persisting into fruiting, base rounded and obliquely inserted on peduncle, apex acute, apiculate, yellow-green, very thinly leathery. Spadix stipitate; stipe 3-4 $\mathrm{mm}$ long; fertile portion $1.8-6 \times 0.4-0.5 \mathrm{~cm}$, cylindrical, yellow. Flowers c. $1.3 \mathrm{~mm}$ diam., with 6 free tepals and 6 stamens. Infructescence with numerous berries; fruits 7-10 $\times 4-7 \mathrm{~mm}$, ellipsoid with a long slender persistent style, ripening red; seeds not observed. - Fig. 37.

Distribution - Malesia: endemic to North Borneo.

Habitat - Lowland forest on shale, slopes and ridges, rarely in peatswamp, $20-80 \mathrm{~m}$ altitude.

Notes - Immediately recognizable by the longer slender persistent styles that give the spadix a bristly appearance and the greatly exserted stamens drying white against the almost black spadix. The reflexed narrow spathe resembles that of $P$. longivaginatus and $P$. barberianus but differs in the much thinner texture.

The type of $P$. hosei, while notable for the very broadly ovate-elliptic leaves, is in inflorescence characters, especially the long style, an almost exact match for the type of P. brevistylus.

Other specimens examined: BORNEO: BRUNEI DARUSSALAM: Temburong, Selapon, lower slopes of Bk. Beliton, S of village, J. Dransfield 6944 (BRUN, K); Belait, Labi, Jalan Melayan, J. Dransfield 7269 (BRUN, K). SARAWAK: 3rd Div., Gaat (Gat), upper Rejang River, Clemens \& Clemens 21936 (A, K); 1st Div., Kuching, Haviland 971 (SING); 2nd Division, Baram Distr., Hewitt s.n. (SING). SABAH: Beaufort, Klias F.R., Dewol \& Karim SAN 77798 (K, KEP, L, SAN, SAR, SING).

\section{Pothos laurifolius P.C. Boyce \& A. Hay, sp. nov.}

Pothos brevistylum accedit sed ab eo foliis subtus glaucis, stigmate sessili, spatha ovata coriacea purpurea persistenti, atque in synflorescentiis elongatis aphyllis florenti differt. Folia dorso glauca adhuc in hoc genere unica sunt. - Type: Brunei Darussalam, Belait, Labi, valley of Sg. Rampayoh, 12 Mar 1993, S. Dransfield 1282 (K, holo; iso BRUN).

Rather slender, heterophyllous(?), root-climbing liane. Shoot system differentiated into free lateral flowering and adherent non-flowering branches; eocaul and seedling not observed. Leaves mid- to deep green, paler to sub-glaucous abaxially, stiffly chartaceous, drying greyish green with a whitish abaxial caste; petiole $7-7 \times 0.3-0.4 \mathrm{~cm}$, 


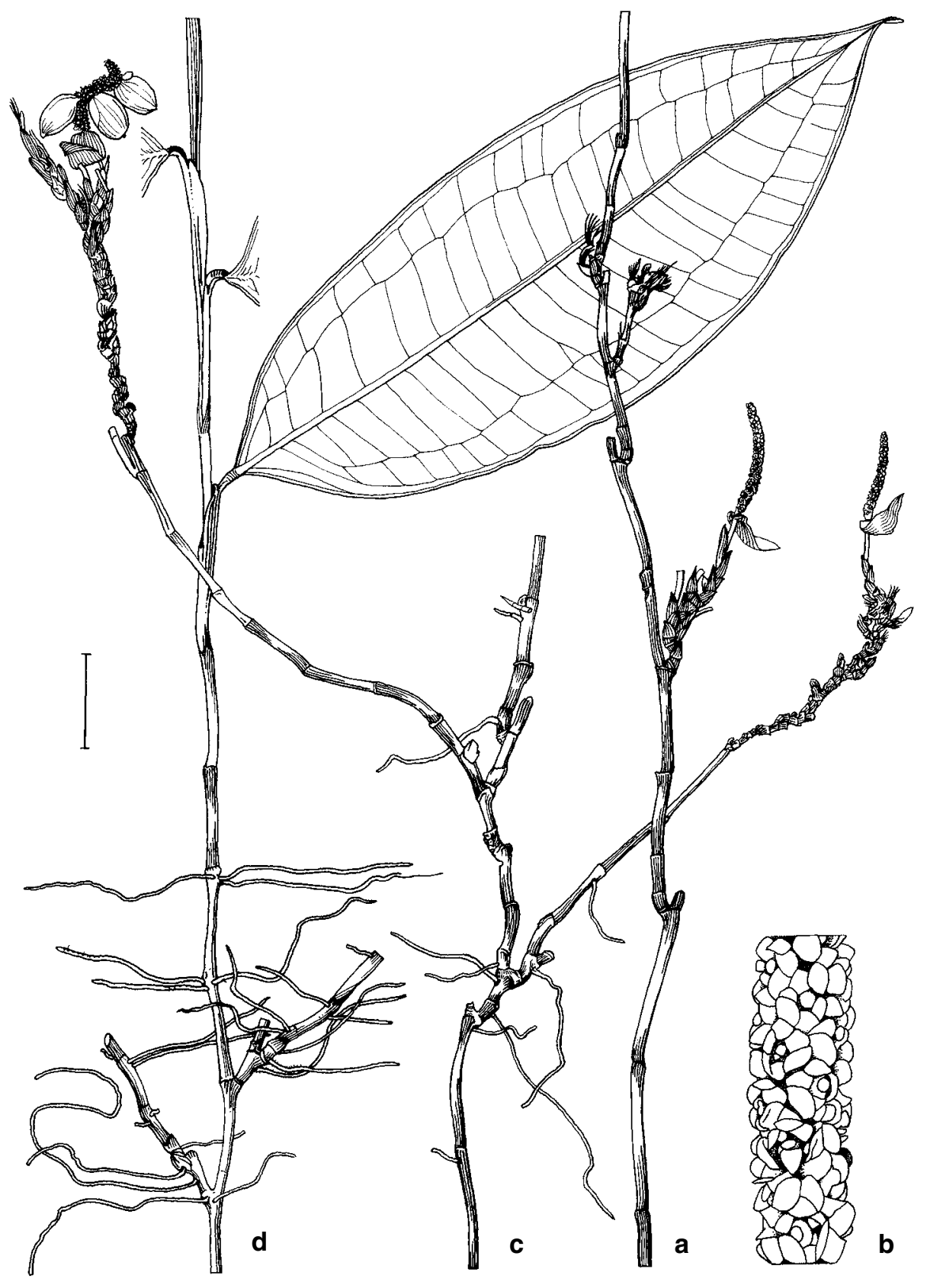

Fig. 38. Pothos laurifolius. $\mathbf{a}$, fertile shoot in flower; $\mathbf{b}$, spadix detail; $\mathbf{c}$, fertile shoot, inflorescence and mature stages of infructescence; $\mathbf{d}$, adherent mature shoot detail: a-b \& d, S. Dransfield 1282; c, Nengkat 248. Scale bar: a, c, d = $2 \mathrm{~cm} ; \mathrm{b}=3.3 \mathrm{~mm}$. 


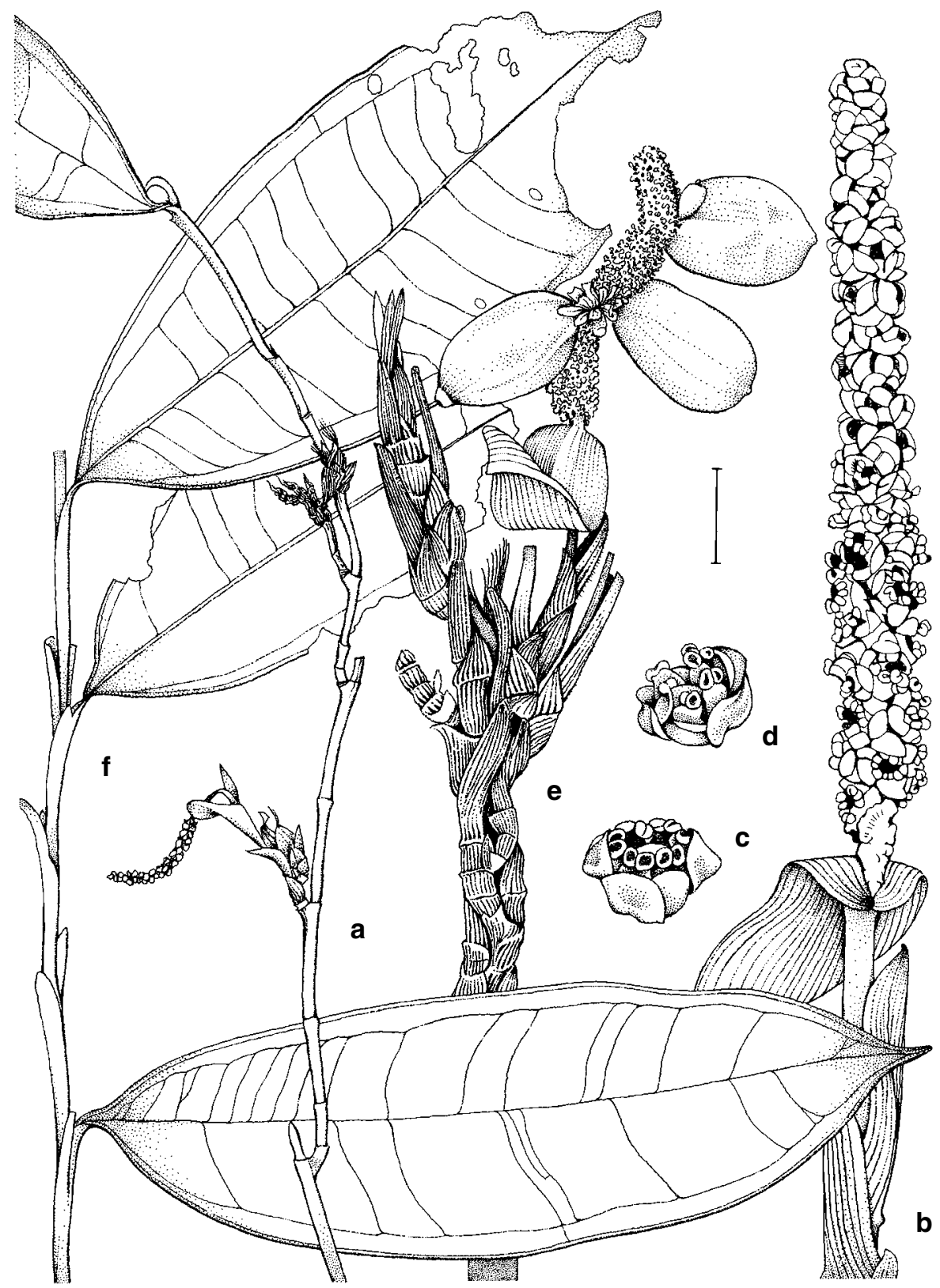

Fig. 39. Pothos laurifolius. $\mathbf{a}$, fertile shoot; $\mathbf{b}$, inflorescence; $\mathbf{c}$, whole flower, front three quarter view; $\mathbf{d}$, whole flower, side three quarter view; $\mathbf{e}$, inflorescence branching system, mature infructescence; f, sterile shoot: a-d \& f, S. Dransfield 1282; e, Nengkat 248. Scale bar: a, $\mathrm{f}=2 \mathrm{~cm} ; \mathrm{b}=3.3 \mathrm{~mm} ; \mathrm{e}=1 \mathrm{~cm}$; c, $\mathrm{d}=1.3 \mathrm{~mm}$. 
rather stout, clasping stem expect for prominent apical geniculum sheath prominent, extending to base of geniculum, clasping basally, ligulate apically; blade 17-20 × 6-8.2 $\mathrm{cm}$, ovate to elliptic, base subacute to obtuse, apex attenuate-mucronate, minutely apiculate; primary lateral veins arising at almost $90^{\circ}$, intramarginal veins 2 per side, the outer intramarginal vein remaining very close and parallel to margin, inner intramarginal vein c. 10-15 $\mathrm{mm}$ distant from margin. Inflorescences erect, subtended by cataphylls, several in sequence on elongated shoots arising from below the axils of distal leaves; peduncle 1-1.5 $\times 0.2-0.3 \mathrm{~cm}$, stout, erect, dark purple-green. Spathe 1.72 $\times 0.7-1 \mathrm{~cm}$, ovate-lorate, spreading to reflexed, base minutely cochleate on the peduncle, apex acute, apiculate, dark purple, stiffly glossy-leathery. Spadix sessile, 2-2.5 $\times 0.3 \mathrm{~cm}$, cylindrical, white. Flowers c. $1.3 \mathrm{~mm}$ diam., with 6 free tepals and 6 stamens. Infructescence with few berries; fruits c. $10 \times 7 \mathrm{~mm}$, ovoid-ellipsoid, ripening red; seeds not observed. - Fig. 38, 39.

Distribution - Malesia: endemic to Borneo (Brunei Darussalam; known only from Labi district).

Habitat - Primary lowland alluvial forest on sedimentaries, $40 \mathrm{~m}$ altitude (only recorded from one specimen).

Note - Approaches P. brevistylus but differs by glaucous-backed leaves (recalling many Lauraceae - hence the epithet), sessile stigma, persistent ovate leathery, purple spathe and in flowering on elongated, foliage-leafless synflorescences. The glaucousbacked leaves are hitherto unique in the genus.

Other specimen seen: BORNEO: BRUNEI DARUSSALAM: Belait, Labi, Kg. Teraja, path to Sarawak border, Nengkat 248 (BRUN, K).

\section{Pothos brassii B.L. Burtt}

Pothos brassii B.L. Burtt, Kew Bull. (1936) 495; Jones \& Gray, Climbing Pl. Austr. (1988) 312. Hay, Blumea 40 (1995) 405-405, fig.1. - Type: Australia, Queensland, slopes of Thornton Peak, 15 Mar 1932, Brass 2311 (K, holo; iso A, BRI, MO).

Slender, not highly ramified, hemi-epiphytic rainforest and gallery forest rootclimbing liane. Shoot system poorly differentiated into non-flowering adherent and flowering branches, the branchlets having the leaves arranged very obviously in two ranks; eocaul thread-like, with a series of gradually larger leaves; seedlings succeeding gradually to adult leaf form. Leaves drying greyish-green; petiole shorter than the blade, sheathing for most of its length, with the sheath usually not quite reaching the geniculum; wings of sheath more or less persistent, eventually becoming fibrous; blade c. $12 \times 5 \mathrm{~cm}$, elliptic, slightly to distinctly falcate, the midrib impressed above, base acute to obtuse, minutely auriculate; primary lateral veins diverging at c. $60-80^{\circ}$, subparallel, running into an intramarginal vein c. $8 \mathrm{~mm}$ from the margin and a submarginal vein c. $3 \mathrm{~mm}$ from the margin. Inflorescence solitary or paired, terminal on leafy ultimate branchlets; peduncle exceeding the petiole of the subtending leaf, green (drying black), with c. 4 short cataphylls at its base (from the axil of one of which the second inflorescence may arise) usually hidden in the leaf sheath, or the first inflorescence without cataphylls and the second arising (with a minute prophyll and short cataphylls) in the axil of the subtending leaf. Spathe c. $2 \mathrm{~cm}$ long, broadly ovate, reflexed, base of the spathe margins somewhat decurrent (c. $3 \mathrm{~mm}$ ) on the peduncle, tip mucronate for c. $3 \mathrm{~mm}$, green. Spadix sessile, c. $2 \mathrm{~cm}$ long, oblong-ovoid, ivorywhite; flowers c. $1.7 \mathrm{~mm}$ diam., with 6 free tepals and 6 stamens, with the anthers fully exserted from the tepals at and after anthesis. Infructescence with 1-few berries; fruit c. $1.3 \mathrm{~cm}$ long, ovoid, orange to orange-red when ripe; seeds not observed. - Fig. 40.

Distribution - Australia (endemic to wet tropical eastern Queensland; locally common between Daintree and Bellenden Ker). 


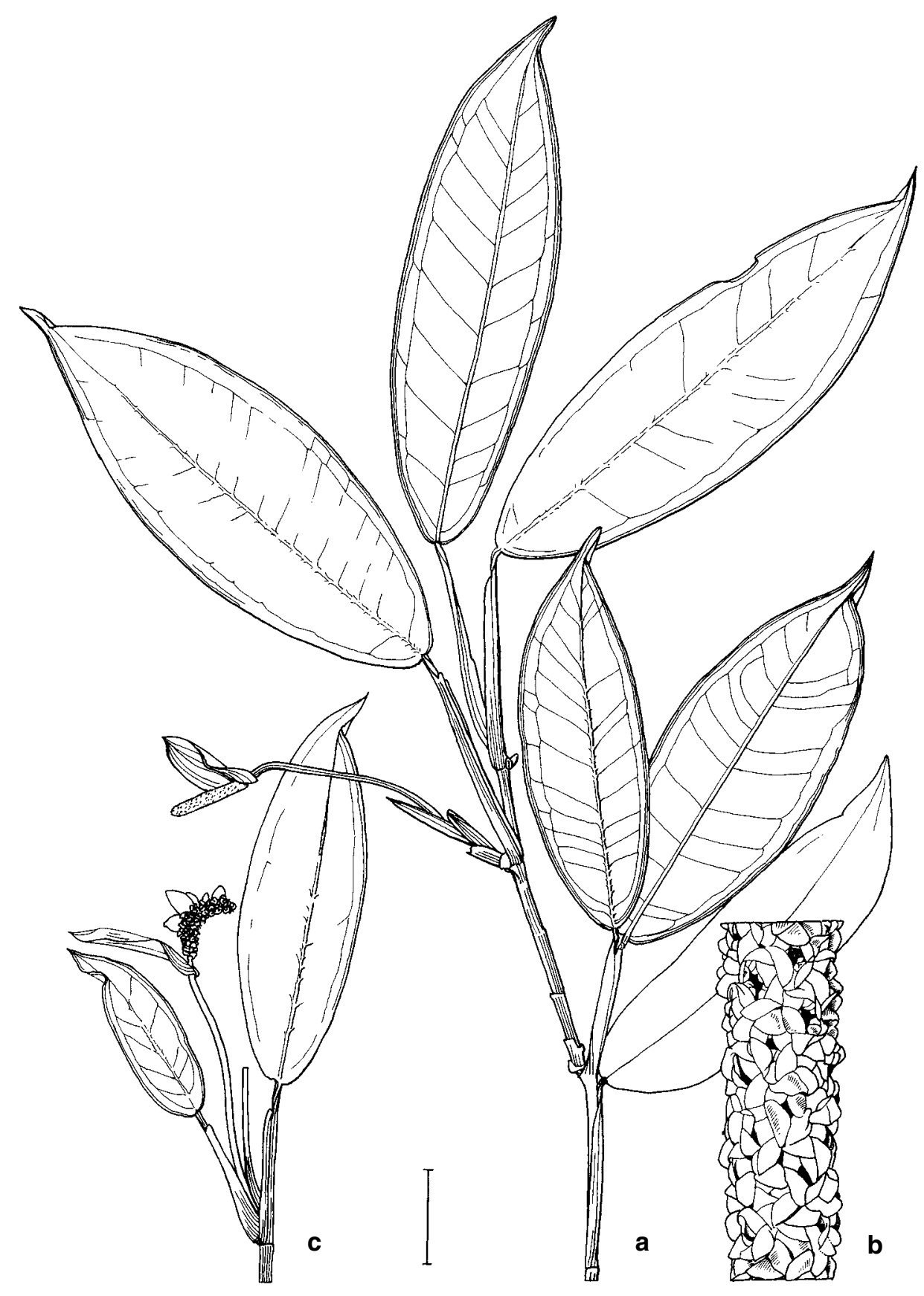

Fig. 40. Pothos brassii. $\mathbf{a}$, fertile shoot; $\mathbf{b}$, spadix detail; $\mathbf{c}$, fertile shoot, mature stage of infructescence: $\mathrm{a}-\mathrm{b}$, Brass 2311; c, Brass $\mathcal{E}$ White 278. Scale bar: a, c $=2 \mathrm{~cm} ; \mathrm{b}=2.7 \mathrm{~mm}$. 
Habitat — In rainforests from the lowlands to c. $1200 \mathrm{~m}$ altitude.

Other specimens examined: AUSTRALIA: Queensland, Daintree River, Brass $\&$ White 278 (A, BRI, K, LAE); Queensland, Daintree River, Flecker 7071 (BRI, QRS); Queensland, Cape Tribulation N.P., Hay 7053 (NSW); Queensland, McDowell Range, Hyland 3792 (BRI, QRS); Queensland, E slope of Bellenden Ker, Hyland 5351 (BRI, QRS); Queensland, VCL Noah, Hyland 8287 (BRI, L, LAE, QRS); Queensland, between McDowell Range and Bloomfield, Gold Hill near China camp, Tracy 14800 (BRI, QRS); Queensland, McDowell Range between Daintree River and Bloomfield River, Webb \& Tracey 10855 (A, BRI, CANB, K, L).

\section{Pothos insignis Engl.}

Pothos insignis Engl. Bull. Soc. Tosc. Ortic. 4 (1879) 267 \& Bot. Jahrb. Syst. 1 (1881) 180 \& in Beccari, Malesia 1 (1883) ('1882') 263, t.17 \& in Engl., Pflanzenr. 21(IV.23B) (1905) 39-40; Ridl., J. Straits Branch Roy. Asiat. Soc. 44 (1905) 188; Merr., J. Straits Branch Roy. Asiat. Soc., special ed. (1921) (1921) 87; Boyce \& Poulsen, Kew Bull. 49 (1994) 523-528. - Type: Malaysia, Sarawak, 1st Div., Matang, Beccari P.B. 953 (FI, holo; iso K, L).

Pothos borneensis Furtado, Gard. Bull. Sing. 8: 148 (1935), syn. nov. - Type: Malaysia, Sarawak, $5^{\text {th }}$ Div., Limbang, Jul 1905, Hewitt s.n. (SING, holo; iso K).

[Pothos basilanensis Furtado, nom. nud. in sched. BM].

Slender to rather robust, homeophyllous(?), root-climbing liane to $10 \mathrm{~m}$. Shoot system very strongly differentiated into adherent non-flowering and flowering shoots, the latter completely and densely clothed by inflated, 7-10 × 1.5-2 cm, overlapping cataphylls; eocaul and seedling not observed. Leaves pale to mid-green adaxially, very slightly paler abaxially; petiole 11-24 cm $\times 3-6.6 \mathrm{~mm}$, slender, strongly channelled, geniculate apically; blade (7-)0.5-34 × (2.5)5-15 cm, lanceolate-elliptic, strongly oblique, base minutely cordate, apex attenuate with a $2-2.5 \mathrm{~mm}$ apiculum; primary lateral veins numerous, arising at $35-45^{\circ}$, intramarginal veins 3 per side, very prominent, the innermost c. $1 / 3$ distant from margin to midrib. Inflorescences few to many together, produced sequentially, each subtended by a robust inflated cataphyll; peduncle $5 \mathrm{~cm} \times 2-3 \mathrm{~mm}$, greenish purple. Spathe $4.5-7.5 \times 1.5-3.5 \mathrm{~cm}$, ovate-elliptic, reflexing at anthesis, base decurrent, apex acuminate, mid-green with a broad purple mark centrally and some purple staining apically. Spadix stipitate; stipe $4-6 \times 1.5-2 \mathrm{~mm}$, decurrent into spathe limb, purple; fertile portion $4.2-9 \times 0.6-1.3 \mathrm{~cm}$, cream. Flowers c. $2.3 \mathrm{~mm}$ diam.; tepals 6 , free; stamens 6 . Infructescence with numerous berries, spathe persistent into fruiting, becoming chartaceous, tepals much increased in size, up to $7 \times 2.5 \mathrm{~mm}$, apparently functioning as protection for developing berries, filament remains abundant, chartaceous; fruit 5-10 $\times 2-3.5 \mathrm{~mm}$, ellipsoid, flattened basally, turbinate apically, young berries dark purple, tinged white, ripe berries white with purplish stylar region, musty fruit-scented; seeds c. $2 \times 3 \mathrm{~mm}$, ovoid, greyish brown. - Fig. 41.

Distribution — Malesia: Borneo, Philippines (Palawan).

Habitat - Lianescent, hemi-epiphytic or lithophytic trunk or treelet climber at base of ridges or near rivers in primary to disturbed primary mixed dipterocarp forest on shales or limestone, at 10-1200 m altitude.

Note - It is not readily apparent to what $P$. insignis is related. While somewhat resembling $P$. tener, it is readily distinguished by the clinging flowering shoots and the fruits ripening to white and notably musty fruit-smelling, the latter suggesting mammal (fruit-bat?) dispersal.

Other specimens examined: BORNEO: SARAWAK: 1st Div., Bau, Seburan Anderson S 26848 (SAR, US); 4th Div., Miri, G. Subis, Niah Caves, outside Great Cave, Anderson S 31901 (SAR); 4th Div., Miri, Niah Caves, S side of G. Subis, Sekaloh River, Anderson et al. S 27551 (SAR, US); 1st Div., Bau, Fairy Caves, c. 7 km from Bau, Boyce 796 (K, M, SAR); 2nd Div., Lubok Antu, Brooke 10699 (BM, 


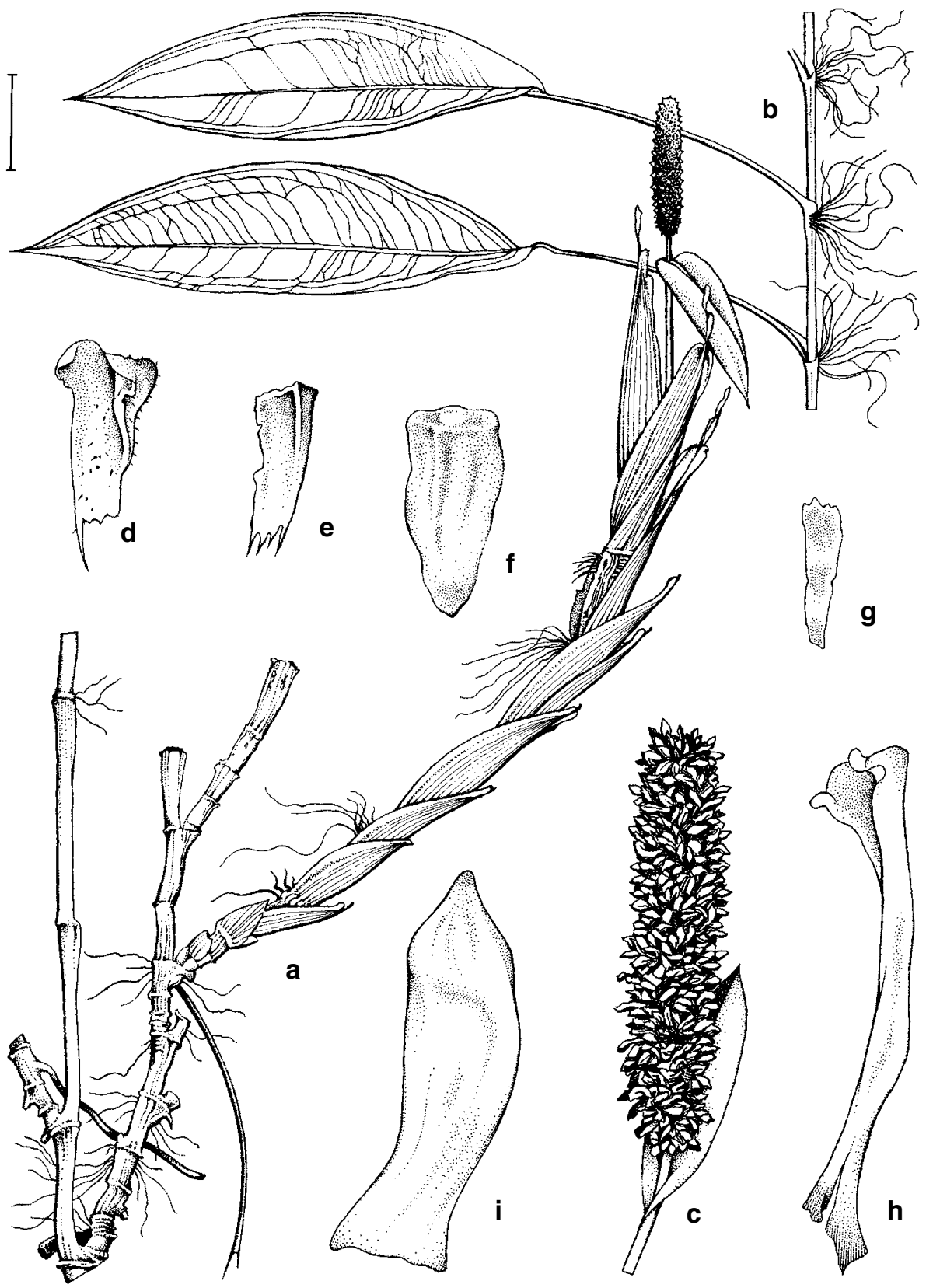

Fig. 41. Pothos insignis. $\mathbf{a}$, fertile shoot; $\mathbf{b}$, adherent sterile adult shoot; $\mathbf{c}$, inflorescence; $\mathbf{d}$, tepal, inside three quarter view; $\mathbf{e}$, tepal, outside three quarter view; $\mathbf{f}$, ovary; $\mathbf{g}$, stamen filament; $\mathbf{h}$, tepal from infructescence, inside three quarter view; $i$, semimature berry: $a-i$, Poulsen 183 . Scale bar: $a=4 \mathrm{~cm}$; $\mathrm{b}=6 \mathrm{~cm} ; \mathrm{c}=3 \mathrm{~cm} ; \mathrm{d}-\mathrm{h}=2 \mathrm{~mm} ; \mathrm{i}=3 \mathrm{~mm}$. 
US); 1st Div., Bidi, Brooks s.n. (SING); 1st Div., along road between Kuching and Padawan, 10 miles SW of main Kuching-Serian highway, Croat 53184 (MO); 2nd Div., Baram Distr., Tutoh, Paku, Long Melinau, Bk. Kala, near Melinau River, Ludong S 31842 (K, L, NSW, SAR); 1st Div., Teng Bukap, 32nd mile Padawan road, Mamit S 32655 (K, L, SAR); 1st Div., 1 mile W of Bau, Nicolson 1290 (US); 4th Div., near Long Kapa, Mt Dulit, Ulu Tinjar, Richards 1452 (K); 1st Div., Bau, Ridley s.n. (SING); 1st Div., Bau, Ridley s.n. (SING). BRUNEI DARUSSALAM: Temburong, Sg. Belalong at Kuala Belalong, Bt. Apoi F.R., Kuala Belalong Field Studies Centre, Webber Booth's Plot, Poulsen 183 (AAU, BRUN, K). SABAH: Lahad Datu, Bk. Tempadong, cliffs and hills along Sg. Segama, Beaman 10089 (MSC, UKMS, US); Dallas, Clemens \& Clemens 261542 (BM); Dallas, Clemens \& Clemens 26542 (BM, SING); Sapulut, base of Bt. Punggul, Kulip E Kantil SAN 133565 (SAN); Sandakan, mile 30, Ulu Dusun, Lantoh SAN 87859 (KEP, SAN, SAR); Sandakan, Gomantong F.R., Dulong Lambu limestone massif, Gomantong limestone hill, Lim et al. 584 (NSW, SAN); Keningau, Lian Cave, Meijer \& Kuripin SAN 51712 (K, SAN). KALIMANTAN: W Kalimantan, G. Bentuang area, 5-10 km $\mathrm{N}$ of Masa village, $150 \mathrm{~km}$ NE of Pontianak, beside Sembawang River, Burley et al. 2350 (A, BO, K); S Kalimantan, Djaro Dam, Muara Uja, J. Dransfield \& Saerudin 2164 (BO); CE Kalimantan, W Koetai, no.5 near Lahoem, Endert 1761 (BO, K); C Kalimantan, Kab. Kotawaringin Timur, Sg. Mentaya, Sangai, $100 \mathrm{~m}$ from pondok on new road, Wilkie 9540 (A, E). PHILIPPINES: Palawan, Bualbualan, Alcacid PNH 6043 (A); Palawan, Chromite Mine site, S. Dransfield \& Madulid 1048 (K); Palawan, Basilan, Reillo BS 15435 (BM, K, US); Palawan, Penigisan, Ølsen 355 (C); Palawan, Irawan River valley, base of Mt Beaufort at Tatanarom, Soejarto \& Madulid 6117 (A); Palawan, Singnapan Ransang, Vendivil \& Juan PNH 126215 (UKMB, PNH).

\section{Pothos cuspidatus Alderw.}

Pothos cuspidatus Alderw., Bull. Jard. Bot. Buitenzorg III, 4 (1922) 337; K. Krause \& Alderw., Nova Guinea 14 (1927) 211; Hay, Blumea 40 (1995) 407, fig.2. - Type: Papua Barat, Jayapura Prov., Doorman summit, 8 Oct 1920, Lam 1566 (BO, holo, photo BRI, LAE; iso L).

Very slender, highly ramified climber or hemi-epiphyte, the branchlets having the leaves interspersed with a greater number of cataphylls. Shoot system architecture unclear; eocaul and seedling not observed. Leaves drying dull dark green; petiole slender, to $2.5 \mathrm{~cm}$ long, c. $1 / 4$ the length of the blade, very narrowly sheathing to the geniculum; blade highly variable in size on a branch, c. $6-12.5 \mathrm{~cm} \times 1.5-4 \mathrm{~cm}$ (sometimes much smaller on ultimate branchlets), ovate-lanceolate to lanceolate, rather abruptly acuminate into prolonged 'drip tips', base acute to somewhat obtuse; primary lateral veins diverging at $45-75^{\circ}$, intramarginal veins one on each side of the midrib, submarginal. Inflorescence solitary, terminal on ultimate leafy branches but subtended by one or more narrow cataphylls to $1.7 \mathrm{~cm}$ long; peduncle 1-2 cm long, very slender. Spathe c. $3 \mathrm{~cm} \times 4 \mathrm{~mm}$, ovate, subulate. Spadix sessile, $1 \mathrm{~cm} \times$ c. $3 \mathrm{~mm}$, oblong. Flowers c. $1.6 \mathrm{~mm}$ diam., with 6 free tepals and 6 stamens. Infructescence with 2-5 berries; fruit 1-1.2 cm × c. $5 \mathrm{~mm}$, elongate-obovoid; seeds not observed. - Fig. 42.

Distribution - Malesia: endemic to western New Guinea (known only from northern Papua Barat in the Taritatau (Idenburgh) River area).

Habitat - Mossy lower montane in forest, 1420-1800 m altitude.

Note - Close to P. polystachyus but differing in the smaller, wider spathe and the more elaborated inflorescence shoots.

Other specimen seen: NEW GUINEA: PAPUA BARAT: Jayapura Prov., Taritatau ('Idenburgh') River, Bernhard Camp, Brass 12100 (A, L).

\section{Pothos polystachyus Engl. \& K. Krause}

Pothos polystachyus Engl. \& K. Krause, Bot. Jahrb. Syst. 54 (1917) 76, fig. 2; Hay, Blumea 40 (1995) 405-407. - Type: Papua New Guinea, W Sepik Prov., Sepik River, Station Felsspitze, 7 Aug 1913, Ledermann 12696 (B, holo). 


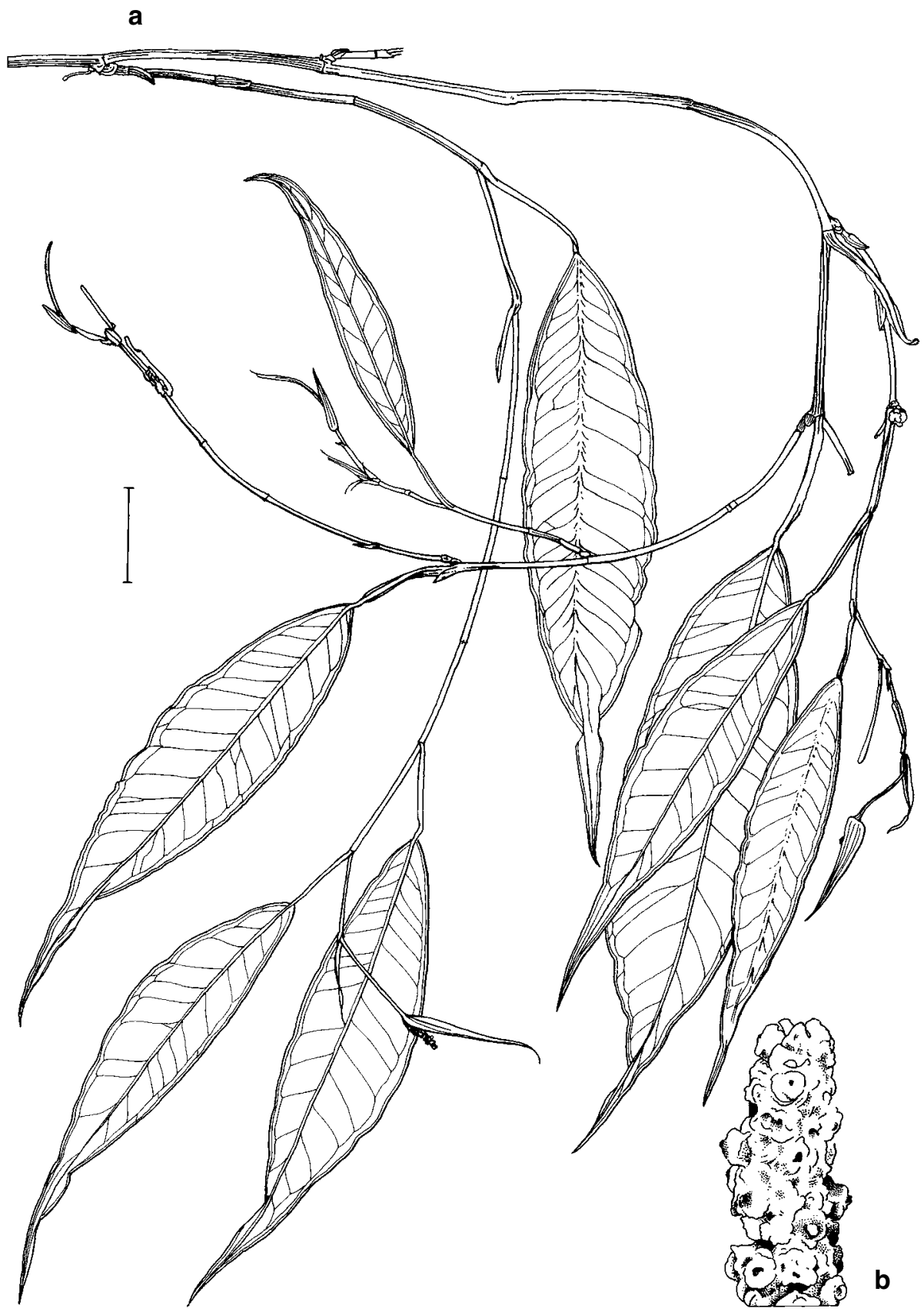

Fig. 42. Pothos cuspidatus. a, fertile shoots; $\mathbf{b}$, spadix detail: $\mathrm{a}-\mathrm{b}$, Brass 12100 . Scale bar: $\mathrm{a}=2 \mathrm{~cm}$; $\mathrm{b}=1.7 \mathrm{~mm}$. 


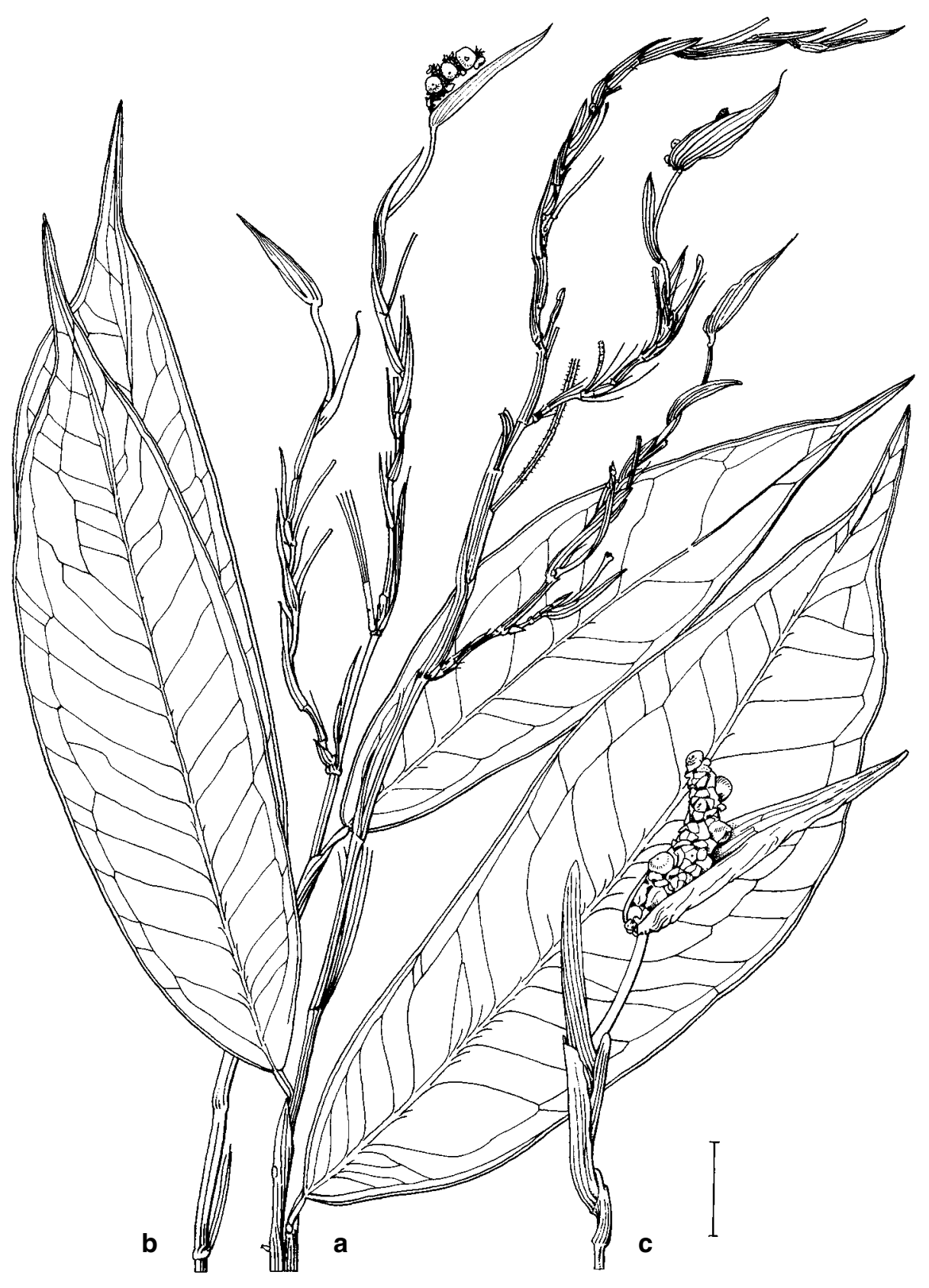

Fig. 43. Pothos polystachyus. a, fertile shoot; $\mathbf{b}$, fertile shoot, mature stage of infructescence; c, infructescence: a-c, Ledermann 12696. Scale bar: a, b = $1.5 \mathrm{~cm}$; $=7 \mathrm{~mm}$. 
Tall, slender root-climbing liane or hemi-epiphyte. Shoot system architecture unknown. Leaves with the petiole $2-5 \mathrm{~cm}$ long, prominently geniculate at the apex, sheathing for most of its length, sheath persistent; blade c. 12-16 $\times 2-4 \mathrm{~cm}$, lanceolate, somewhat oblong and falcate, rather stiff, tip acuminate, base acute; primary lateral veins diverging at c. $30-60^{\circ}$, intramarginal veins one on each side of the midrib, submarginal. Inflorescence a lax, compound, much-ramified, sympodial synflorescence, the modules consisting of a prophyll, 3 or 4 cataphylls, a terminal inflorescence and a relay bud in the axil of the last cataphyll - the lower cataphylls sometimes with similar modules in their axils; synflorescence cataphylls lanceolate, 6-12 mm long; peduncle c. $2-4 \mathrm{~cm}$ long, very slender, subtended by a cataphyll almost as long. Spathe 3.5-4 cm long, ovate-lanceolate, acuminate, about twice the length of the spadix. Spadix sessile, to c. $2 \mathrm{~cm} \times$ c. $3 \mathrm{~mm}$, cylindrical; flowers c. $1.6 \mathrm{~mm}$ diam., with 6 free tepals and 6 stamens. Infructescence with 4-6 berries; fruit globose, c. $5 \mathrm{~mm}$ diam. Fig. 43.

Distribution - Malesia: endemic to New Guinea (Papua New Guinea, West Sepik Province; known only from the type collection).

Habitat — Lower montane rainforest, c. $1400 \mathrm{~m}$ altitude.

Notes - This species is evidently closely related to P. cuspidatus (q.v.), differing in the less markedly cuspidate leaf and spathe, the somewhat longer spadix, the smaller globose fruit and in the much-ramified synflorescence.

The illustration cited above shows a rather more highly ramified synflorescence than that in the type specimen. Possibly there was a second sheet that did not survive the wartime damage to Berlin.

\section{Pothos falcifolius Engl. \& K. Krause}

Pothos falcifolius Engl. \& K. Krause, Bot. Jahrb. Syst. 54 (1917) 76; Hay, Blumea 40 (1995) 407-408, fig.3. - Type: Papua New Guinea, E Sepik Prov., Hunsteinspitze, 3 Mar 1913, Ledermann 11309 (B, holo).

Moderately robust hemi-epiphytic root-climbing liane often with root-thorns at the nodes. Shoot system architecture unclear; eocaul and seedling not observed. Leaves rather stiffly chartaceous, mid- to dark green abaxially and adaxially; petiole $2.5-9 \mathrm{~cm}$ long, sheathing up to or just short of the geniculum, sheath persistent; blade 10-28 $\times$ 2-11 cm, ovate to elliptic to elliptic-lanceolate, somewhat falcate when narrow, tip acute to gradually or abruptly acuminate, base acute to obtuse to somewhat auriculate, midrib clearly off-centre, prominent abaxially, flush or impressed adaxially; primary lateral veins diverging at $45-85^{\circ}$, intramarginal veins 1 or 2 , continuing more or less the length of the blade from the base or running to the margin and replaced by another about midway up the blade. Inflorescence solitary and terminal on free leafy shoots or on sympodial, leafless, cataphyll-bearing, simple branch systems borne among the leaves (initially?) to (later?) complex perennial(?) branch systems borne on older parts of the stem. Spathe c. $2.3-7 \mathrm{~cm}$ long, oblong-lanceolate, deflexed, usually persisting into fruit, white. Spadix stipitate; stipe $2-3 \mathrm{~mm}$ long; fertile portion $2-4 \mathrm{~cm}$ $\times$ c. $2 \mathrm{~mm}$ diam. (up to c. $6 \mathrm{~cm} \times$ c. $7-8 \mathrm{~mm}$ diam. when fruiting), markedly distally tapering. Flowers c. $1 \mathrm{~mm}$ diam, somewhat distant, sunk in pits in the spadix, tepals 4 , united into an operculum with a central pore over the floral pit, stamens 4 , the anthers at the mouth of the perianth at anthesis. Infructescence with many fruits, fruiting perianth c. 4-5 mm diam, spreading, with the margins split into irregular segments, forming a cupule beneath the berry; fruit 1-2 cm long, ovoid to subcylindric, ripening yellow through orange to dark red with watery pulp; seeds c. $9 \times 3 \mathrm{~mm}, 1$ or 2 per fruit, dark brown. - Fig. 44. 


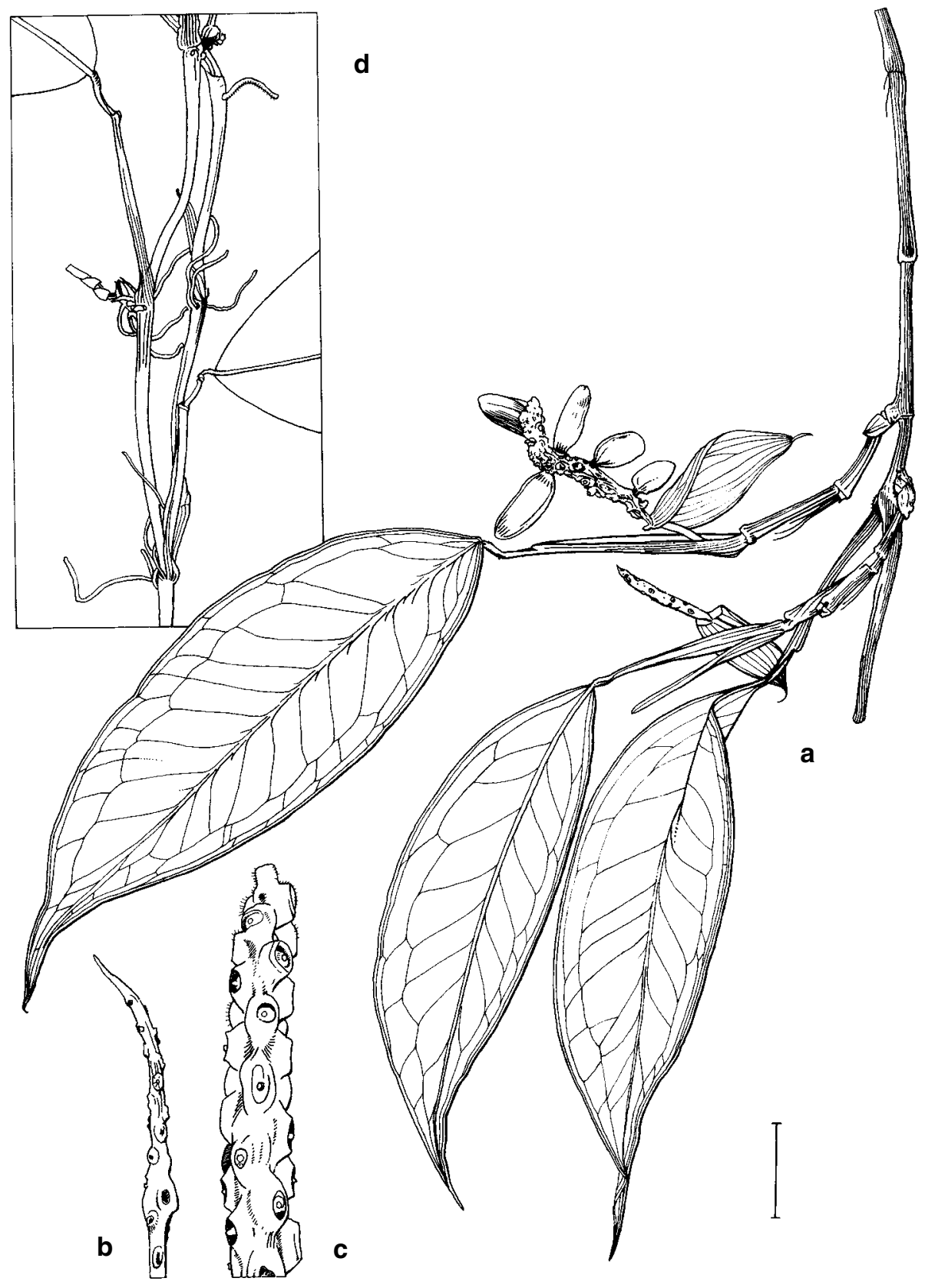

Fig. 44. Pothos falcifolius. $\mathbf{a}$, fertile shoot with inflorescence and mature infructescence; $\mathbf{b}$, whole spadix; c, spadix detail; d, adherent mature shoot detail: a, Ledermann 11309; b-c, Foreman \& Katik NGF 48482; d, Frodin NGF 32077. Scale bar: a, d = $2 \mathrm{~cm} ; \mathrm{b}, \mathrm{c}=2.7 \mathrm{~mm}$. 
Distribution - Malesia: Maluku and widespread in western parts of New Guinea.

Habitat - Forested areas from the lowlands to mid-montane rainforest up to c. $2200 \mathrm{~m}$ alt.

Notes - Apparently a rather widespread and variable but under-collected species. The sunken flower with four stamens and the perianth united into an operculum, markedly asymmetric leaf blades and the spines formed at the nodes from adventitious roots are distinctive. The latter character is otherwise known only in Pothos armatus C.F.C. Fischer (NW India).

Other specimens examined: MALUKU: P. Morotai, Totodoku, Kostermans 782 (BO, K); P. Morotai, G. Pare-Pare, Kostermans 1092 (A, BO, SING). NEW GUINEA: PAPUA BARAT: Biak, Yapen Is., Sumberbaba, near Serui, Aet \& Idjan 841 (BO, L); ?Jayapura Prov., Atasrip 238 (BO); Jayapura Prov., Taritatau (Idenburgh) River, 6 km SW of Bernhard Camp, Brass 13030 (A, L); Cenderawasih Prov., Wandammen Peninsula, Wondiwoi Mts, BW 13337 (L), BW 13634 (L), BW 13717 (L); Kepala Burung Prov., Sorong, Remoe, Main 443 (L); Mimika Prov., Freeport Concession Area, in front of Golf Club towards access road, Utteridge 311 (BO, K, MAN); Kepala Burung Prov., Tohkiri Mts, Aifat River valley, van Royen \& Sleumer 7245 (L). PAPUA NEW GUINEA: Western Prov., Kiunga, T'mingondok, 6 miles ENE of Kiunga, Foreman $\mathcal{E}$ Katik NGF 48482 (A, BO, BRI, CANB, K, L, LAE, NSW, SING, US); Southern Highlands Prov., Tari, vicinity of Habono rest house, $6 \frac{1 / 2}{2}$ miles W of Mt Ne, Frodin NGF 32077 (L, LAE, US); E Sepik Prov., Wagu, Ambunti, Hoogland \& Craven 10354 (K, L); Gulf Prov., Mt Bosavi, N side, Jacobs 8779 (L); W Sepik Prov., Amanab, Imonda Patrol Post, LAE 52888 (L, LAE); Madang Prov., Crater Mt , Mack 509 (NSW); E Sepik Prov., Hunstein Range, ridge between Wagu and Bani, Takeuchi 5419 (BISH, K).

\section{'Goniurus Supergroup'}

\section{Pothos beccarianus Engl.}

Pothos beccarianus Engl. in A. \& C. D.C., Monogr. Phan. 2 (1879) 92 \& in Engl., Pflanzenr. 21(IV.23B) (1905) 44, fig.17; Ridl., J. Straits Branch Roy. Asiat. Soc. 44 (1905) 187; Merr., J. Straits Branch Roy. Asiat. Soc., special ed. (1921) 86. - Type: Malaysia, Sarawak, 1st Div., Matang, May 1869, Beccari p.b. 1699 (FI, holo; iso B, K, P).

Slender, heterophyllous, root-climbing liane. Shoot system architecture unclear; eocaul thread-like, with scattered minute bracts, then abruptly becoming shingling; seedling shingle-leaved, then abruptly producing adult leaves; flowering shoot much abbreviated, (foliage) leafless. Leaves coriaceous, deep-green, paler abaxially, drying mid-green to brown; petiole 1.5-4 $\times 0.1-0.2 \mathrm{~cm}$, rather stout, apex prominently geniculate, sheath mostly indistinct, occasionally spreading and apically ligulate in very large leaves; blade $4-26 \times 1.5-6 \mathrm{~cm}$, narrowly oblong elliptic to narrowly elliptic, very occasionally slightly unequal and falcate, apex acuminate to long-acuminate, apiculate, apicule later deciduous, base acute to obtuse; primary lateral veins arising at $70-80^{\circ}, 2$ intramarginal veins per side, 2-10 $\mathrm{mm}$ from blade margin, arising from just above base of the midrib, remaining \pm parallel to margin, terminating at the tip of the blade. Inflorescences several at different stages on a reiterating flowering shoot; peduncle 1-2.5 × c. $0.1 \mathrm{~cm}$, slender, strongly curving or straight, the inflorescence held erect, purple-green. Spathe $0.8-1.5 \times$ c. $0.6 \mathrm{~cm}$, ovate, base rounded, annularly inserted on to peduncle, apex acuminate, reddish pink. Spadix stipitate; stipe 5-20 $\times 0.5-0.8 \mathrm{~mm}$, terete, pubescent, yellow to dark pink; fertile portion 3-8 $\times 0.2-0.3 \mathrm{~cm}$, very slendercylindric, pubescent, straight to markedly zig-zagging (even on same synflorescence), yellow to dark pink. Flowers c. $1.8 \mathrm{~mm}$ diam., widely scattered, arranged in a lax spiral along the spadix with 6 free tepals and 6 stamens. Infructescence with few berries; fruit 8-9 × 4-5 mm, oblong-ellipsoid; seeds not observed. - Fig. 45.

Distribution - Malesia: endemic to Borneo (not yet recorded from Kalimantan). 


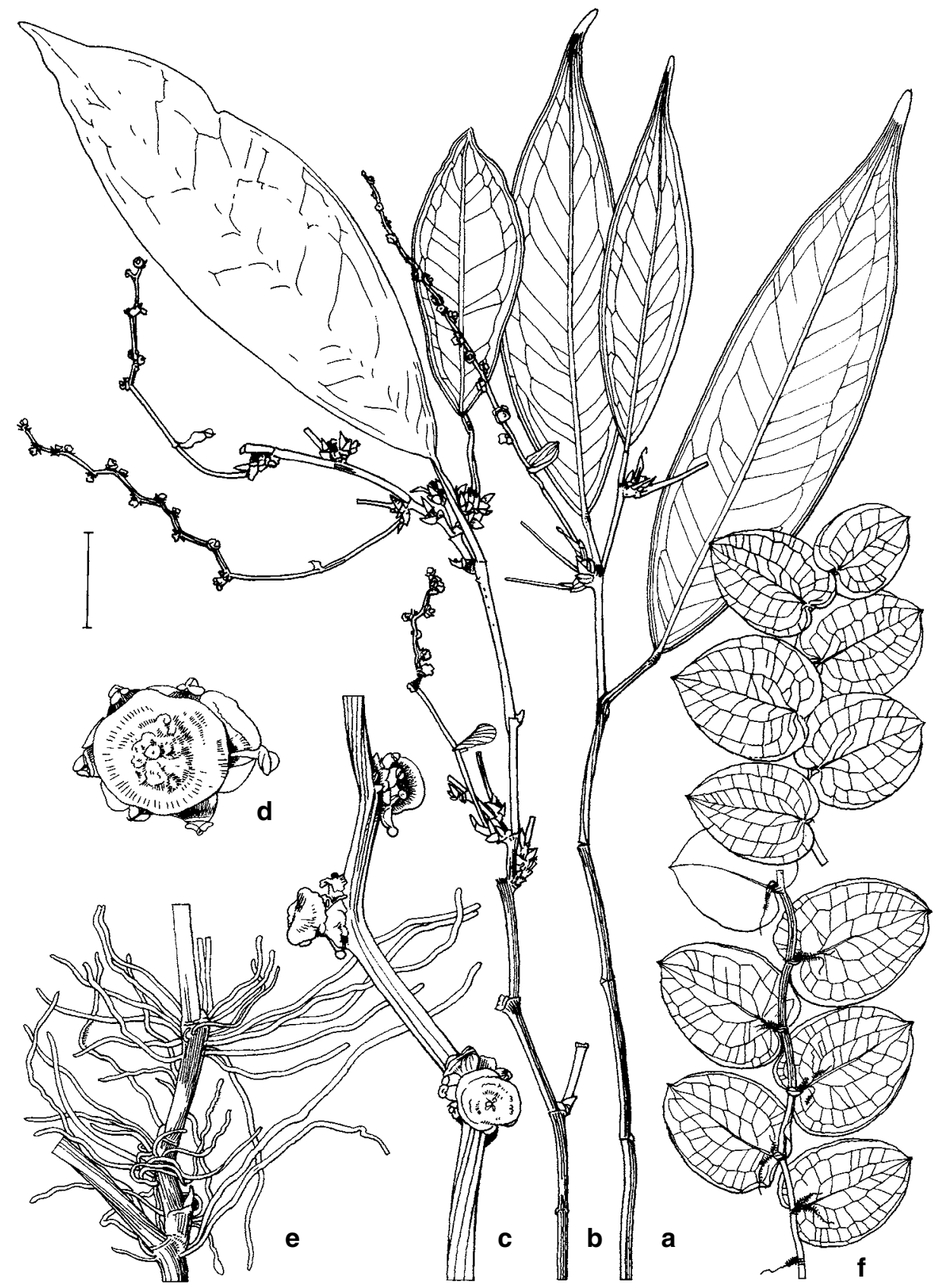

Fig. 45. Pothos beccarianus. a, $\mathbf{b}$, fertile shoots; $\mathbf{c}$, spadix detail; $\mathbf{d}$, whole flower, top view; e, adherent branching system, detail; f, juvenile shingle plant: a: Awa \& P.C. Yii S 46634; b-d, Fidilis SAN 118616; e, Poulsen \& Eri 174; f, Burbidge s.n. Scale bar: a, b, $\mathrm{f}=2 \mathrm{~cm} ; \mathrm{c}=2 \mathrm{~mm} ; \mathrm{d}=1 \mathrm{~mm}$; $\mathrm{e}=2.7 \mathrm{~cm}$. 
Habitat - Primary to variously disturbed lowland to hill forest, on slopes and ridgetops, very occasionally in kerangas, $135-820 \mathrm{~m}$ altitude.

Notes - One of three 'goniurid' Pothos endemic to Borneo, P. beccarianus is notable for the frequently long, pubescent inflorescences with the flowers set directly on the spadix axis and not (as is the case in P. motleyanus) on a swollen pad.

As with many other Pothos, $P$. beccarianus displays a marked degree of size-related variability. In particular the development of the inflorescence seems closely linked to the vigour of the plant or even of an individual branch, with as much as $300 \%$ size difference between inflorescences of comparable age on different duplicates of the same collection.

There are two colour forms of $P$. beccarianus. The commoner form has yellow inflorescences, the rarer dark pink.

Other specimens examined: BORNEO: SARAWAK: 4th Div., Dulit range, Awa \& P.C. Yii S 46634 (K, KEP, L, SAN, SAR, US); 'Native collector' BS 2176 (K); 4th Div., Mulu N.P., slopes of G. Mulu, above camp 2, Primack $S 42411$ (A, K, KEP, L, SAN, SAR); 5th Div., Limbang, Ulu Sg. Medamit, Wright \& Ismawi S 32296 (BO, K, L, SAN, SAR, SING, US); 4th Div., Niah N.P., Sg. Sekaloh, P.C. Yii S 40139 (B, K, KEP, L, MO, SAN, SAR); 1st Div., 17th mile Bau - Lundu road, G. Raya, P.C. Yii $\mathcal{E}$ Jegong $S 45988$ (K, KEP, L, SAN, SAR, US). BRUNEI DARUSSALAM: Temburong, Sg. Temburong at Kuala Belalong, ridge W of River, Boyce 445 (BRUN, K); Temburong, Amo, Bk Belalong, J. Dransfield 7169 (BRUN, K). Temburong, Batu Apoi F.R., ridge W of Kuala Belalong Field Studies Center slope, Poulsen \& Eri 174 (AAU, BRUN, K). SABAH: No further data, Burbidge s.n. (A, K); Kinabalu, Sg. Mesilau, Chew \& Corner RSNB 4977 (A, K, LE, SING, US); Nabawan, Fidilis S 118616 (K, SAN); Keningau, Tulid area, Ulu Sg. Sembauan, Fidilis SAN 125636 (K, SAN); Keningau, Pisagon, Fidilis SAN 128252 (K, KEP, SAN); Keningau, Pensiangan F.R., Jimpin SAN 110325 (K, KEP, L, SAN, SAR); Keningau, Ulu Sg. Matud, Jimpin SAN 119408 (K, SAN); Tenom, Mandalom F.R., Sg. Punti, Mantor SAN 120314 (K, SAN); Tongod, Pinangah F.R., Tuyuk \& Hassan SAN 117169 (K, KEP, SAN).

\section{Pothos curtisii Hook.f.}

Pothos curtisii Hook.f., Fl. Brit. Ind. 6 (1893) 554; Engl. in Engl., Pflanzenr. 21 (IV.23B) (1905) 43; Boyce, Blumea 45 (2000) 186-189, fig.10. - Type: Malaysia, Perak, Larut, Kunstler ('Dr King's collector') 3887 (K, lecto; isolecto CAL, SING, selected by Boyce (2000: 186)).

Pothos peninsularis Alderw., Bull. Jard. Bot. Buitenzorg III, 1 (1920) 381. - Pothos latifolius Hook.f., Fl. Brit. Ind. 6 (1893) 554; Engl. in Engl., Pflanzenr. 21 (IV.23B) (1905) 42, nom. illeg., non Pothos latifolius L. (1759) (Maluku). - Type: Malaysia, Perak, Larut, Kunstler ('Dr King's collector') 3903 (K, lecto, isolecto CAL, SING, selected by Boyce (2000: 187)).

Pothos kunstleri Hook.f., Fl. Brit. Ind. 6 (1893) 554; Engl. in Engl., Pflanzenr. 21 (IV.23B) (1905) 42. - Type: Malaysia, Perak, Larut, Kunstler ('Dr King's collector') 2754 (K, lecto, selected by Boyce (2000: 187)).

Pothos maingayi Hook.f., Fl. Brit. Ind. 6 (1983) 554; Engl. in Engl., Pflanzenr. 21 (IV.23B) (1905) 43. - Type: Malaysia, Malacca, 1867-1868, Maingay 1538 (K, lecto, selected by Boyce (2000: 187)).

Slender, heterophyllous, root-climbing liane to $3 \mathrm{~m}$. Shoot system architecture unclear; eocaul not observed; seedling shingle-leaved; flowering shoot much abbreviated to rarely rather elongated through reiteration, (foliage) leafless or, occasionally, bearing undersize foliage leaves. Leaves mid-green, paler abaxially, drying mid-green to brown, stiffly coriaceous; petiole $2-10.5 \times 0.1-0.6 \mathrm{~cm}$, slender, canaliculate, rounded abaxially, base decurrent, apex prominently geniculate, sheath distinct, prominent, erect, apically ligulate in young growth, ligule later disintegrating; blade $8-26 \times 1.6-9.5 \mathrm{~cm}$, 


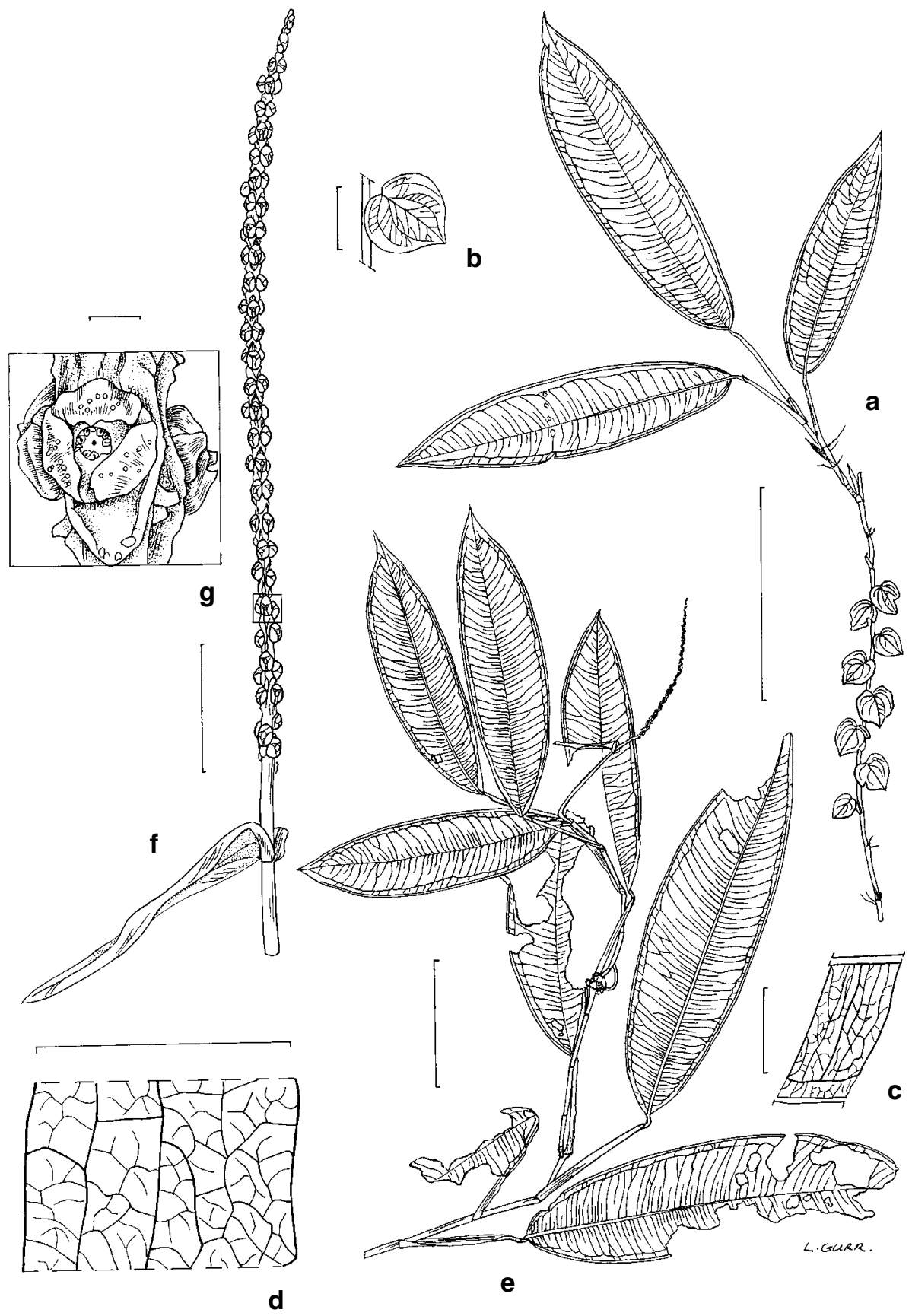

Fig. 46. Pothos curtisii. a, juvenile/mature sterile transition shoot; $\mathbf{b}$, shingle leaf; $\mathbf{c}$, mature sterile lamina venation detail midrib and intermarginal vein; $\mathbf{d}$, venation detail; $\mathbf{e}$, fertile shoot; f, inflorescence; g, spadix detail: $\mathrm{a}-\mathrm{g}$, Boyce 1094 . Scale bars: $\mathrm{a}=10 \mathrm{~cm} ; \mathrm{b}=1 \mathrm{~cm} ; \mathrm{c}=1 \mathrm{~cm} ; \mathrm{d}=5 \mathrm{~mm}$; $\mathrm{e}=8 \mathrm{~cm} ; \mathrm{f}=2 \mathrm{~cm} ; \mathrm{g}=1 \mathrm{~mm}$. 
broadly to narrowly oblong elliptic, apex acuminate to long-acuminate, apiculate, apicule later deciduous, base obtuse; primary lateral veins arising at $45-70^{\circ}$, 2 intramarginal veins per side, $2-13 \mathrm{~mm}$ from blade margin, arising from just above base of the midrib, remaining \pm parallel to margin, terminating at the tip of the blade. Inflorescence solitary to several at different stages on a reiterating flowering shoot; peduncle 2.5-6.5 $\times 0.1-0.4 \mathrm{~cm}$, somewhat robust, strongly curving or straight, the inflorescence held erect, mid-green. Spathe 3.4-6.7 × c. $1 \mathrm{~cm}$, linear-triangular to narrowly oblong, base rounded, annularly inserted on to peduncle, apex acuminate, slightly rough, pale brown tinged reddish pink. Spadix stipitate; stipe 3-19 $\times 1-2 \mathrm{~mm}$, terete; fertile portion $3.5-13.5 \times 0.5-0.3 \mathrm{~cm}$, very slender-cylindric, occasionally sterile at the tip, pale greyish pink, older inflorescences blackish red. Flowers c. $1.6 \mathrm{~mm}$ diam., widely scattered, arranged in a lax spiral along the spadix with 6 free tepals and 6 stamens. Infructescence with few to many berries; fruit 6-11 $\times 5-7 \mathrm{~mm}$, ellipsoid to oblong-ellipsoid; seeds not observed. - Fig. 46.

Distribution - Thailand (Narathiwat). In Malesia: Sumatera (Sumatera Utara and Jambi provinces), Peninsular Malaysia, Singapore.

Habitat - Wet upper hill, hill and lowland primary to secondary evergreen forest, on a variety of substrates, occasionally on limestone, 60-1200 m altitude.

Notes - Easy to identify in Peninsular Malaysia as it is the only goniurid Pothos there. It is very similar to $P$. beccarianus (Borneo) but distinguishable by much longer petioles (up to $10.5 \mathrm{~cm}$ vs $4 \mathrm{~cm}$ in $P$. beccarianus), prominent petiole sheath, stiffly chartaceous (not coriaceous), leaf blades and roughened (not pubescent) spadix.

For such a distinctive species (the only representative of the remarkable Goniurus supergroup in continental SE Asia) P. curtisii has a chequered taxonomic history; three of its four synonyms were described on the same page of the Flora of British India. Of these synonyms, Hooker's P. latifolius (the name most often applied to P. curtisii in herbaria) is illegitimate, being antedated by P. latifolius L. (q.v.). Alderwerelt was aware of this and published a new name, P. peninsularis (Alderwerelt 1920), for Hooker's P. latifolius. However, Alderwerelt apparently had not appreciated that Hooker had described the same species under four different names.

Other specimens examined: PENINSULAR MALAYSIA: Pahang, SW Pahang, W Lesong F.R., near Sg. Jekati, Ahmad \& Shukor 527 (A, C, SING); Malacca, Alvins 106 (SING); Perak, Matang, Bubu F.R., Compartment 76 Boyce 698 (K, KEP); Negeri Sembilan, Pasoh F.R., trail to and environs of new Canopy Walkway, Boyce 1094, Boyce 1335 (K, KEP); Perak, Trolak F.R., Chelliah KEP 104636 (K, KEP, SING); Penang, Bt. Ferringgi, Curtis 808 (K, SING); Perak, Taiping Curtis 2987 (SING); Kedah, G. Baling, Furtado s.n. (SING); Negeri Sembilan, Selaru F.R., Holttum 9727 (BO, K, SING); Selangor, Sg. Buloh, R.R.J. Experiment Station, Kaimal s.n. (SING); Selangor, Campus forest, U.K. Bangi, Kasim \& Zai 2994 (UKMB); Terengganu, Jambu Bongkok F.R., Dungun, Kassim s.n. (UPM); Perak, Larut, Sunkei ('Sunkei Perak'); Kunstler ('Dr King's collector') 3012 (BM, CAL, K, SING); Perak, Larut, Kunstler ('Dr King's collector') 4221 (BM, CAL, K); Perak, Waterfalls Hill, Kunstler ('Dr Kings' Collector') 4236 (BM, SING); Perak, Thaiping (Taiping) Larut, Kunstler ('Dr King's collector') 8493 (BM, CAL, K); Malacca, Maingay 3041 (K); Terengganu, Jambu Bongkok F.R., Dunggun, Mk. Ar. 4957 (UKM); Perak, Taiping, along road to Maxwell's Hill Station, Nicolson 1070 (SING, US) \& 1071 (SING, US); Johore, Ulu Endau, Labis F.R., Compartment 285, Ogata KEP 110386 (A, K, KEP, SING); Terengganu, Jambu Bongkok F.R., Poore KL 1169 (UPM); Selangor, 15th mile Padang track, Ridley s.n. (SING); Perak, Dindings, Ridley 7248 (K, SING); Perak, G. Kelidang, Ridley 9696 (SING); Perak, Dindings, Ridley 10318 (K, SING); Perak, Taiping Hills, Ridley 11420 (BM, K, SING), Selangor, Kuala Lumpur, Ridley's collector s.n. (SING); Perak, Scortechini 624a (K); Perak, probably Larut, Scortechini 675 (K); Perak, G. Bujang Melaka, Chenderiang Peak, Shah et al. 3367 (C, KEP, MO, SING); Penang, Telok Aling, Sinclair SING 39378 (E, K, SING, US). SINGAPORE. Jurong Road, 15th mile, Corner SING 26102 (K, SING); Kranji, Goodenough 5108 (BM, SING); Kranji, Lanclasse 40 (P); Bk. Mandai, Mat s.n. (SING); 
Bk. Mandai, Ridley 6535 (SING); Bk. Mandai, Ridley s.n. (SING). SUMATERA: Sumatera Utara, Kualu (Koealoe), near the Aekanopan (Aek Kanopan), Loendoet concession, Bartlett 8450 (US); Jambi, Pasir Mayang, P.T. IFA concession, Vreeken-Buijs 70 (BO, L) \& 71 (BO, L).

\section{Pothos luzonensis (C. Presl) Schott}

Pothos luzonensis (C. Presl) Schott, Oesterr. Bot. Wochenbl. 5 (1855) 19; Miq., Flora Ned. Indië 3 (1856) 182; Schott, Aroideae (1856-1857) 25, t.56 \& Prodr. Syst. Aroid. (1860) 574-575; Merr., Enum. Philippine Pl. 1 (1922) 173; Engl. in A. \& C. D.C., Monogr. Phan. 2 (1879) 93-94 \& in Engl., Pflanzenr. 21(IV.23B) (1905) 42-43. - Goniurus luzonensis C. Presl, Epimel. Bot. (1851) 244. - Type: Philippines, Luzon, Albay Prov., 1841, Cuming 1045 (PRG, holo; iso BM, E, G, K, L, LE, M, MO, P).

Slender to rather robust, (heterophyllous?), root-climbing liane. Shoot system architecture unclear; eocaul and seedling not observed; flowering shoot much abbreviated, (foliage) leafless. Leaves chartaceous to somewhat coriaceous, drying midgreen to brown with the mid-rib and (in larger leaves) primary venation yellowish; petiole $2-9 \times 0.1-0.4 \mathrm{~cm}$, slender, canaliculate, rounded abaxially, base decurrent, apex prominently geniculate, sheath distinct, prominent, erect, apically ligulate in young growth, ligule and sheath margins later scarious-disintegrating; blade 8-28 $\times 1-10 \mathrm{~cm}$, narrowly to oblong or broadly falcate-elliptic, apex acuminate to long-falcate acuminate (the latter especially in broader leaves), apiculate, apicule later deciduous, base obtuse, largest leaves minutely peltate or, rarely, prominently cordate; primary lateral veins arising at 35-45, 2 intramarginal veins per side, $2-15(-20) \mathrm{mm}$ from blade margin, arising from just above base of the midrib, remaining \pm parallel to margin, terminating at the tip of the blade. Inflorescence several to many together at different stages from a reiterating flowering shoot; peduncle $2.5-22 \times 0.1-0.4 \mathrm{~cm}$, rather slender, curving or straight. Spathe 2-6 × c. $1 \mathrm{~cm}$, oblong to narrowly oblong, base rounded, annularly inserted on to peduncle, apex acuminate. Spadix stipitate; stipe 3-18 $\times 0.5-1 \mathrm{~mm}$, terete; fertile portion 7-18 $\times 0.5-0.3 \mathrm{~cm}$, slender-cylindric, straight to markedly zigzagging. Flowers c. $1.8 \mathrm{~mm}$ diam., widely scattered, arranged in a lax spiral along the spadix sometimes on a low 'receptacle', with 6 free tepals and 6 stamens. Infructescence with few berries; fruit (immature) 6-9 6 4-6 mm, oblong-ellipsoid; seeds not observed. - Fig. 47.

Distribution - Malesia: endemic to the Philippines (Luzon and Samar).

Habitat — Dense hill to upper hill forest, 700-1100 m altitude.

Notes - The only goniurid Pothos in the Philippines and thus easy to identify as fertile material. It is most similar to P. beccarianus (Borneo) but separable by the falcate, oblique leaf blades, glabrous spadix and longer, narrow spathe.

Pothos luzonensis is very variable. Some populations tend towards having the individual flowers raised on a weak 'receptacle' whereas others have the flowers simply inserted on the spadix axis. In addition there are forms notable for narrow leaf blades and straight spadices and others (including the type) with wider leaves and zig-zagging spadices; the very largest leaves tending to prominently cordate bases, a rather rare condition in Pothos. Despite the extremes of variability, a range of intermediates occurs and the variability is not here considered to be of taxonomic significance.

Other specimens examined: PHILIPPINES: Luzon, Abra Prov., Massisiat, Mt Portoc, Sitio Garau, Alcasid et al. PNH 1660 (A, K, PNH); Luzon, Bataan Prov., Curran FB 5948 (US); Luzon, Ilocos Norte, Mt Semenublan, E of Neuva Era, Iwatsuki et al. 234 (AAU, BKF, C, K, KYO, L, MO, PNH); Luzon, Ilocos Norte, Mt Semenublan, E of Neuva Era, Iwatsuki et al. 243 (BKF, C, K, KYO, L, MO, PNH, SING); Luzon, Rizal, Montalban, Loher 7036 (K, US); Luzon, Rizal, Montalban, Loher 7037 (K, US); Luzon, Rizal, Balacbac, Loher BS 13067 (P); Luzon, Tayabas Prov., Kinatakutan, Oro FB 30841 (SING); Luzon, Camarines Prov., Ramos BS 1529 (A, BM, L, MO, SING); Luzon, Zambales Prov., 


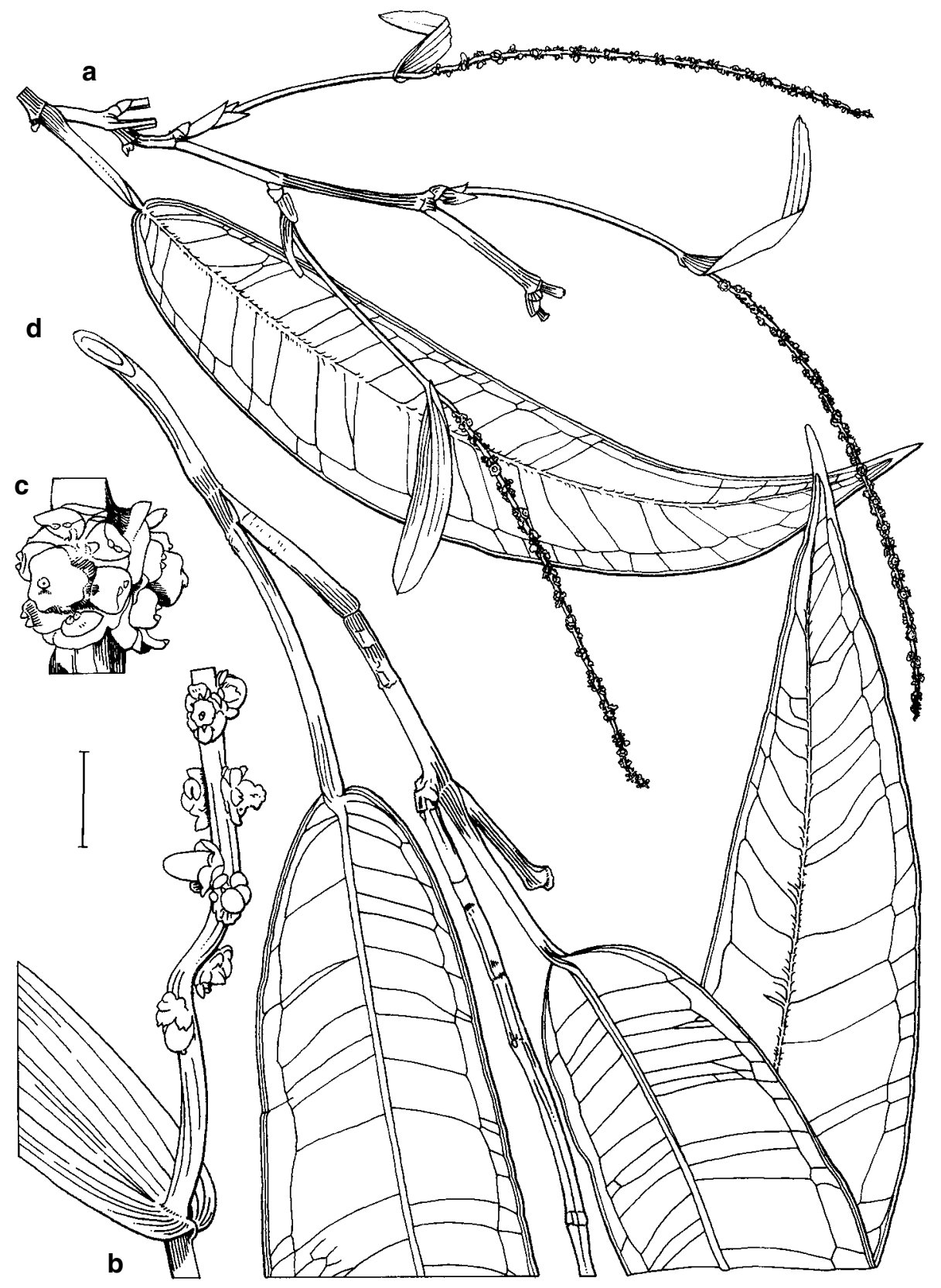

Fig. 47. Pothos luzonensis. $\mathbf{a}$, fertile shoot; $\mathbf{b}$, base of inflorescence; $\mathbf{c}$, spadix detail; $\mathbf{d}$, mature shoot detail: a-d, Sulit PNH 6399. Scale bar: a, $\mathrm{d}=2 \mathrm{~cm} ; \mathrm{b}=7 \mathrm{~mm} ; \mathrm{c}=2.7 \mathrm{~mm}$. 
Mt Marangay, Ramos E Edaño BS 44533 (BO, L, LE, SING); Samar, Mt Catubig, Wright, Sulit PNH 6399 (L); Luzon, Ilocos Norte, Mt Tagki, Neuva Era, Veridinil \& Regnoso PNH 121685 (K, PNH); Luzon, Camarines Prov., Mt Isarog, Vidal 3967 (A, K).

\section{Pothos motleyanus Schott}

Pothos motleyanus Schott, Aroideae (1856-1857) 25, t.55 \& Prodr. Syst. Aroid. (1860) 574; Engl. in A. \& C. DC, Monogr. Phan. 2 (1879) 94 ('mottleyanus') \& in Engl., Pflanzenr. 21 (IV.23B) (1905) 42; Ridl., J. Straits Branch Roy. Asiat. Soc. 44 (1905) 187; Merr., J. Straits Branch Roy. Asiat. Soc., special ed. (1921) 87. - Type: 'Malaysia, Sabah, P. Labuan' Motley 99 (K, holo). See notes below.

Rather robust, heterophyllous, root-climbing liane. Shoot system architecture unclear; eocaul not observed; seedling shingle-leaved; flowering shoot much abbreviated, (foliage) leafless, reiterating. Leaves stiffly coriaceous, very shortly ginger-tomentose abaxially, drying mid-brown with orange-brown abaxial surface; petiole $1.5-5 \times$ $0.1-0.2 \mathrm{~cm}$, stout, weakly canaliculate, rounded abaxially, apex prominently geniculate, sheath wide with two short, triangular ligules at tip, but soon degrading and not conspicuous in older portions of plant; blade $7-25 \times 2-13 \mathrm{~cm}$, narrowly to very broadly oblong-elliptic, oblique, falcate or not, apex acuminate, apiculate, base obtuse to slightly cordate; primary lateral veins arising at $70-85^{\circ}, 2$ intramarginal veins per side, 2-20 $\mathrm{mm}$ from blade margin, arising from just above base of the midrib, remaining \pm parallel to margin, terminating at the tip of the blade. Inflorescences several together at different stages; peduncle $2-4 \times 0.1-0.4 \mathrm{~cm}$, slender, curving or straight, the inflorescence held erect to spreading, tending to become pendent into fruiting. Spathe $2.2-2.5 \times 0.2-0.25 \mathrm{~cm}$, linear, base rounded, annularly inserted on to peduncle, apex acuminate. Spadix stipitate; stipe 7-10 mm long, terete; fertile portion $6-9 \times 0.1-0.2 \mathrm{~cm}$, slender-cylindric, tomentose. Flowers c. $1.6 \mathrm{~mm}$ diam., widely scattered, arranged in a lax spiral each on a an expanded 'receptacle', with 6 free tepals and 6 stamens. Infructescence with few berries; fruit 8-11 $\times 5-6 \mathrm{~mm}$, ellipsoid to oblong-ellipsoid; seeds not observed. - Fig. 48.

Distribution - Malesia: endemic to Borneo. See notes below.

Habitat - Not recorded.

Notes - Pothos motleyanus is immediately recognizable by stiffly coriaceous, abaxially ginger-tomentose leaf blades. It is one of three goniurid Pothos endemic to Borneo, the others are $P$. beccarianus (which has similar large inflorescences but with the flowers not raised on swollen pads, and thinly coriaceous leaf blades lacking the gingertomentose backs) and P. oliganthus (which is distinguishable by the considerably smaller and fewer-flowered glabrous inflorescences).

The only specimen with incontrovertible provenance is Jaheri sub Exped. Nieuwenhuis 996 from Central Kalimantan. The type is annotated as (Pulau) Labuan, Sabah, but we have seen no further collections from Labuan and have not encountered this highly distinctive species in mainland Sabah, Brunei or Sarawak. It seems most probable that the type came from much further south in Borneo (see van Steenis (1950) for details of Barber and Motley collecting localities) and that P. motleyanus is endemic to Kalimantan.

Other specimens examined: BORNEO: KALIMANTAN: Further data and collector's name illegible, 574 (BO); C Kalimantan, Bk. Moang, Jaheri sub Exped. Nieuwenhuis 996 (BO).

\section{Pothos oliganthus P.C. Boyce E A. Hay, sp. nov.}

Plerumque non rite in herbariis utpote Pedicellarum paiei agnitus est, sed inflorescentiis minutis perpaucifloris flores sessiles unoquoque receptaculo carenti ferentibus ac sepalis liberis statim distinguibilis. Coniunctio eadem characterum inflorescentiarum 


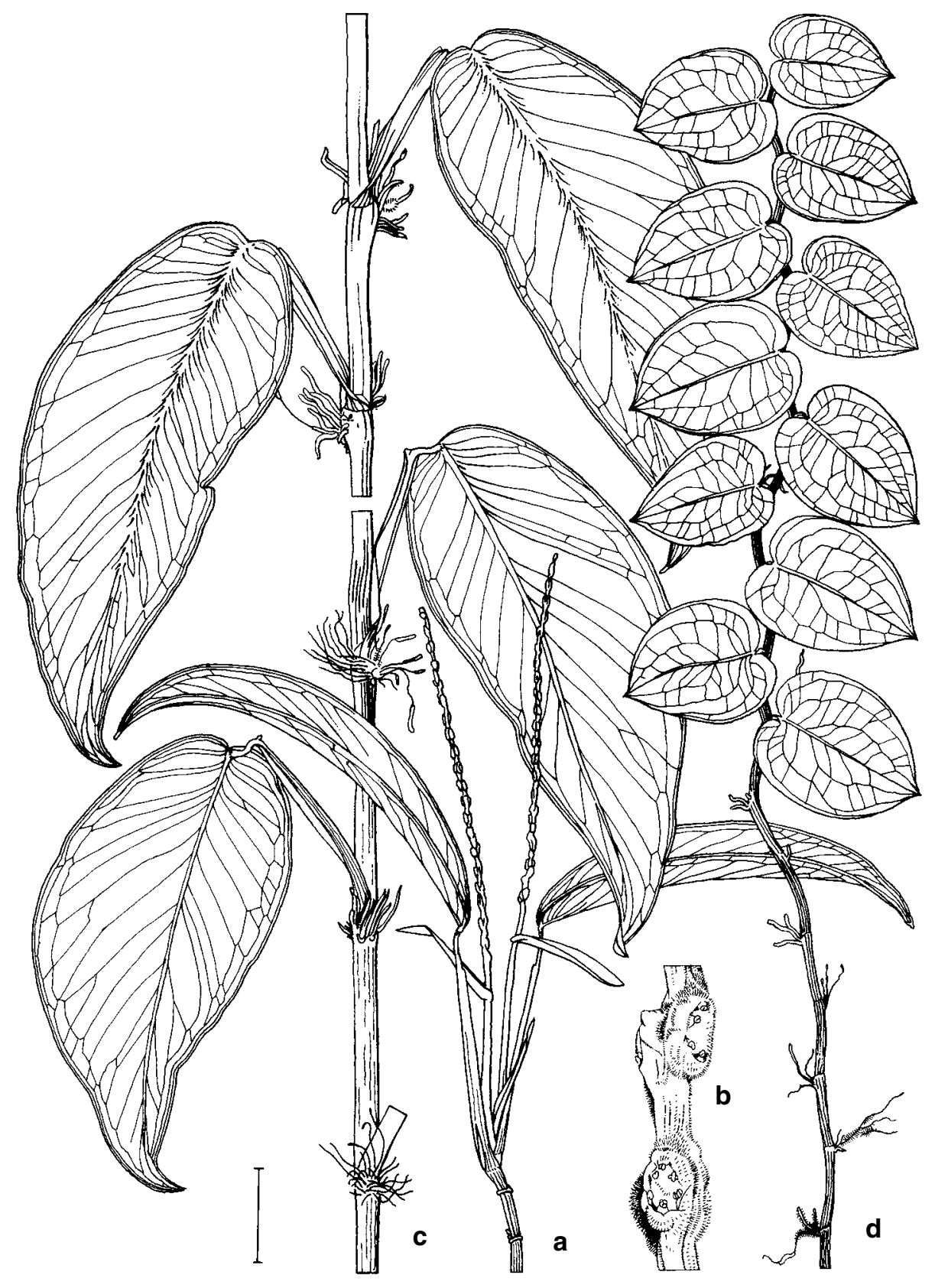

Fig. 48. Pothos motleyanus. a, fertile shoot; $\mathbf{b}$, spadix detail; $\mathbf{c}$, lower part of adherent adult shoot; d, upper part of adherent adult shoot; e, shingle shoot: a-e, Motley 99. Scale bar: a, c, d = $2 \mathrm{~cm}$; $\mathrm{b}=1.6 \mathrm{~mm}$. 
etiam P. oliganthum ab omnibus ceteris speciebus generis Pothi separat. - Type: Malaysia, Sarawak, 2nd Div., Sri Aman, 85th mile, Ulu Sg. Silantek Kiri, path from G. Silantek, 26 Aug 1980, I. Paie S 42566 (K, holo; iso A, L, MO, SAN, SAR).

Slender, (heterophyllous?), root-climbing liane. Shoot system architecture unclear; eocaul and seedling not observed; flowering shoot much abbreviated (foliage) leafless. Leaves chartaceous to somewhat coriaceous, drying greenish brown; petiole $0.4-3 \times$ $0.1-0.12 \mathrm{~cm}$, slender, very narrow-canaliculate, apex weakly geniculate, sheath distinct, prominent, erect, apically ligulate in young growth, ligule later disintegrating; blade 6-21 $\times 1-4.5 \mathrm{~cm}$, very narrowly to narrowly elliptic, oblique, weakly falcate, apex long-acuminate, apiculate, apicule later deciduous, base obtuse; primary lateral veins arising at $60-70^{\circ}, 2$ intramarginal veins per side, $2-8 \mathrm{~mm}$ from blade margin, arising from just above base of the midrib, remaining \pm parallel to margin, terminating at the tip of the blade. Inflorescence solitary, rarely several at different stages on a reiterating flowering shoot; peduncle $0.3-1.3 \times 0.05-0.1 \mathrm{~cm}$, very slender, pale green. Spathe c. $3 \times 2 \mathrm{~mm}$, oblong-ovate, cucullate, base rounded, apex acuminate, white. Spadix stipitate; stipe 1-7 mm long, terete; fertile portion $0.3-0.5 \mathrm{~cm}$, very slender-cylindric, white. Flowers usually 3, seldom more than 5, per inflorescence, c. $1 \mathrm{~mm}$ diam., slightly scattered, with 6 free tepals and 6 stamens. Infructescence with few fruits; fruit (immature) 3-5 × 2-3 mm, obclavate ellipsoid; seeds not observed. - Fig. 49.

Distribution - Malesia: endemic to Borneo (E \& S Sarawak).

Habitat - Mixed lowland to hill dipterocarp forest or kerangas on slopes and ridges, 300-540 m altitude.

Note - Frequently misidentified in herbaria as Pedicellarum paiei (q.v.) but immediately distinguishable by the very small, very few-flowered inflorescences bearing sessile flowers lacking a receptacle, and the free tepals. This same combination of inflorescence characters also serves to separate $P$. oliganthus from all other species of Pothos.

Other specimens examined: BORNEO: SARAWAK: 3rd Div., Belaga, Linau, Sg. Iban, Lee S 45534 (K, L, MO, SAN, SAR, US); 1st/2nd Div. Boundary, G. Buri, 75th mile, Martin \& Ismawi S 36660 (K, KEP, L, MO, SAR, US); 1st Division, Bk Buri, Paie S 42082 (K, L, SAN, SAR, US).

\section{Pedicellarum}

Pedicellarum M. Hotta, Acta Phytotax. Geobot. 27 (1976) 61-65; Nicolson, Aroideana 7 (1984) 56-57; Mayo et al., Genera of Araceae (1997) 100, pl.6, pl. 108B. - Type: Pedicellarum paiei M. Hotta.

Rather slender rarely secondarily hemi-epiphytic (see Croat 1990: 11; Putz \& Holbrook 1986), root climbing, heterophyllous, liane. Shoot system weakly differentiated into adherent, physiognomically monopodial (see Boyce 1998, Boyce \& Nguyen 1995, Boyce \& Poulsen 1994, Boyce \& Hay 1998, Boyce 2000, Hay 1995) non-flowering shoots and free, sympodial fertile shoots, inflorescences arising from highly ramified, abbreviated shoots arising from beneath the leaf; seedling a cataphyll-bearing but otherwise leafless, photosynthesising thread-like eocaul; adult plants producing flagelliform, leafless (cataphyll-bearing), skototropic, foraging shoots; juvenile plants shingle-leaved; internodes (except at the beginning of branches) much longer than thick. Leaf blades simple, entire, narrowly lanceolate to elliptic, even-sided to slightly asymmetrical, with reticulate venation, the primary lateral veins on each side of the midrib traversed by two intramarginal veins running \pm from the base and from about midway along the midrib to the apex, or first to the distal margins and then to the 


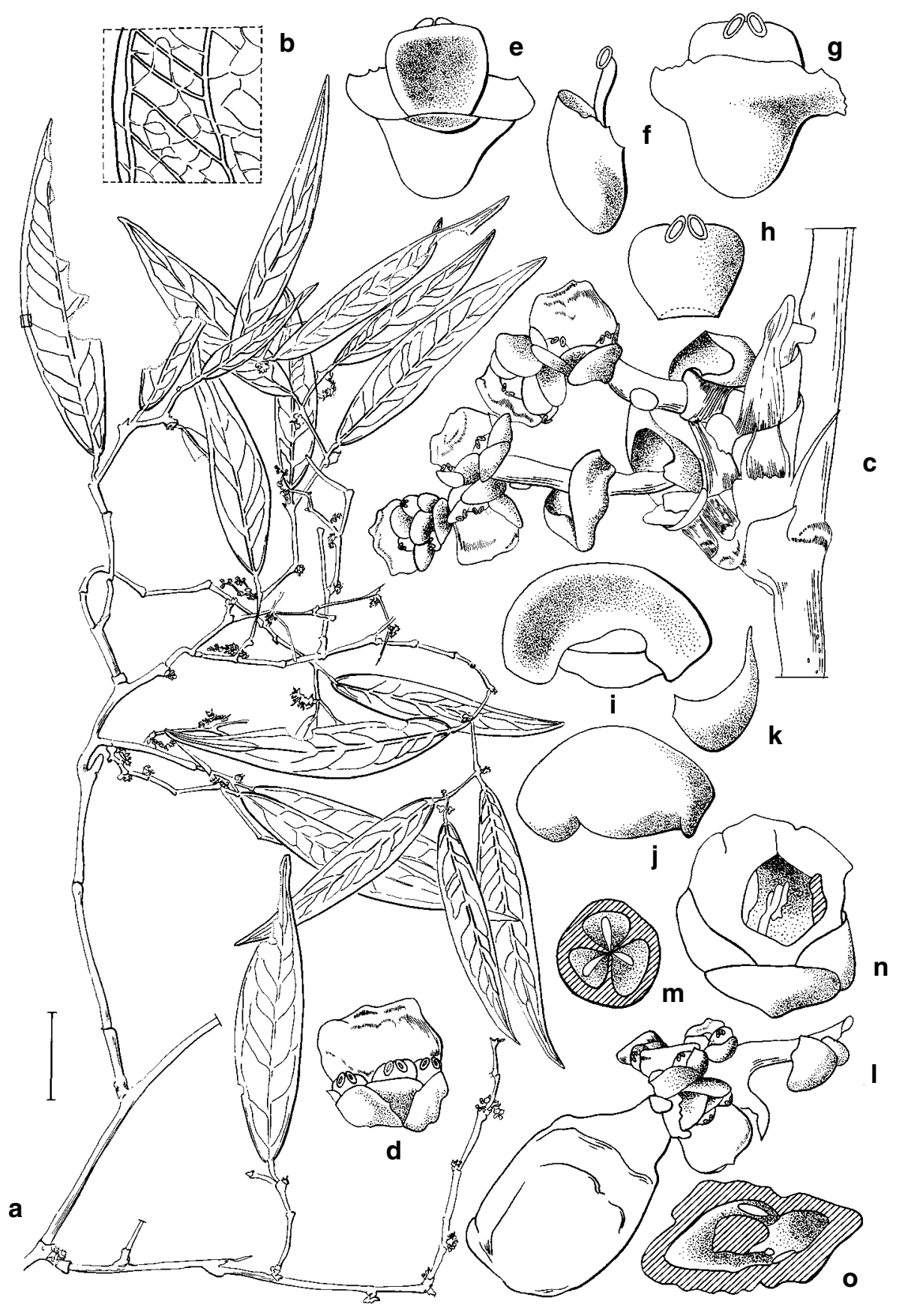

Fig. 49. Pothos oliganthus. a, fertile shoots; $\mathbf{b}$, venation detail; $\mathbf{c}$, inflorescences; $\mathbf{d}$, whole flower, side view; e, tepal and stamen, inside view; $\mathbf{f}$, tepal and stamen, side view; $\mathbf{g}$, tepal and stamen, outside view; $\mathbf{h}$, stamen, ventral view; $\mathbf{i}$, tepal, bottom view; $\mathbf{j}$, tepal, top view; $\mathbf{k}$, tepal, side view; 1, infructescence; $\mathbf{m}$, ovary, transverse section; $\mathbf{n}$, ovary, window cut into side, tepals in place; o, fruit, transverse section: $a-o$, Paie $S 42566$. Scale bar: $a=3 \mathrm{~cm} ; b, c, 1=2.2 \mathrm{~mm}$; \& o $=1.7 \mathrm{~mm}$; $\mathrm{e}-\mathrm{h}, \mathrm{m}, \mathrm{n}=1.1 \mathrm{~mm} ; \mathrm{i}, \mathrm{j}, \mathrm{k}=0.8 \mathrm{~mm}$. 
apex; petiole with a narrow, \pm clasping sheath and a conspicuous apical geniculum. Inflorescences arranged on lateral short shoots bearing cataphylls and elaborated by sympodial branching into leafless, highly complex, compact synflorescences bearing two to many inflorescences flowering in series, synflorescences borne along leafy branches or on older leafless parts of the stem, sometimes arising from there. Spathe inconspicuous, ovate, opening wide and held away from the spadix, green to yellow. Spadix long-stipitate, axis flexuose, minutely hispid-papillose. Flowers bisexual, scattered, on short pedicels, with a large and conspicuous receptacle, and a perianth of 6 completely united tepals forming a cup-like structure; stamens 6, free, with broad, flattened, filaments and latrorse anthers, thecae ellipsoid ovary trilocular, the locules uniovulate, ovules anatropous on an axile placenta at the base of the septum; stigma umbonate, sessile. Fruit a 1-3-seeded elongate oblong-ellipsoid berry ripening from green through yellow to bright red, individually distinct and (relative to spadix) very large; seeds large, exalbuminous compressed-ellipsoid, testa smooth, thin, embryo macropodal. Pollen monosulcate, ellipsoid-oblong, small [mean 17 m (Grayum 1984, 1992)], exine reticulate, minutely muri-tuberculate. Chromosomes: not recorded.

Distribution - One species; endemic to Borneo.

Habitat - Primary to disturbed secondary lowland to upper hill forest on slopes or river banks, 150-1000 $\mathrm{m}$ altitude.

\section{Pedicellarum paiei M. Hotta}

Pedicellarum paiei M. Hotta, Acta Phytotax. Geobot. 27 (1976) 61-65; Nicolson, Aroideana 7 (1984) 56-57; Mayo et al., Genera of Araceae (1997) 100, pl.6, pl.108B. Type: Malaysia, Sarawak, 9th Div., Serian, G. Penrissen, 3 May 1962, I. Paie S 16354 (KYO, holo; iso K, L, SING).

Slender, heterophyllous, root-climbing liane. Shoot system differentiated into nonflowering adherent and free, lateral flowering stems; eocaul not observed seedling shingle-leaved; flowering shoot much abbreviated, (foliage) leafless. Leaves stiffly chartaceous, mid-green, paler abaxially, drying mid-green to brown; petiole 1-2 $\times$ 0.1-0.2 cm, slender, very narrowly canaliculate, apex geniculate, sheath very indistinct; blade $5-16 \times 1.5-5 \mathrm{~cm}$, broadly to narrowly elliptic or ovate-elliptic, apex acuminate to long-acuminate, straight to markedly falcate, apiculate, apicule later deciduous, base subacute to obtuse; primary lateral veins arising at $60-70^{\circ}, 2$ intramarginal veins per side, $2-6 \mathrm{~mm}$ from blade margin, arising from just above base of the midrib, remaining \pm parallel to margin, terminating at the tip of the blade. Inflorescence solitary to rarely paired; peduncle $6-8 \times$ c. $0.1 \mathrm{~mm}$, very slender, straight, the inflorescence held erect to spreading, greenish yellow. Spathe 4-6 6 c. $4 \mathrm{~mm}$, ovate, base rounded, annularly inserted on to peduncle, apex acuminate, greenish yellow. Spadix stipitate; stipe 3-4 × c. $0.9 \mathrm{~mm}$, terete; fertile portion $2-3.5 \times$ c. $0.15 \mathrm{~cm}$, slendercylindric, prominently zig-zagging, greenish yellow. Flowers 5-11 per inflorescence, c. $2 \mathrm{~mm}$ diam., widely scattered, briefly stipitate, arranged in two rows along the spadix with a prominent receptacle, 6 fused tepals forming a cup and 6 free stamens. Infructescence with few berries (but generally each flower fertile); fruit 6-13 $\times 4-6 \mathrm{~mm}$, elongate oblong-ellipsoid with a prominently truncate apex; seeds elongate-ellipsoid, 4-6 $\times$ 3-4 mm. - Fig. 50 .

Distribution - As for genus.

Habitat - As for genus.

Note - Much material in herbaria hitherto annotated as Pedicellarum paiei is referable to Pothos oliganthus (see above), despite Pedicellarum being immediately distinguishable by the larger, more floriferous inflorescences, stipitate receptacled flowers and the cup-like structure formed by the fused tepals. 


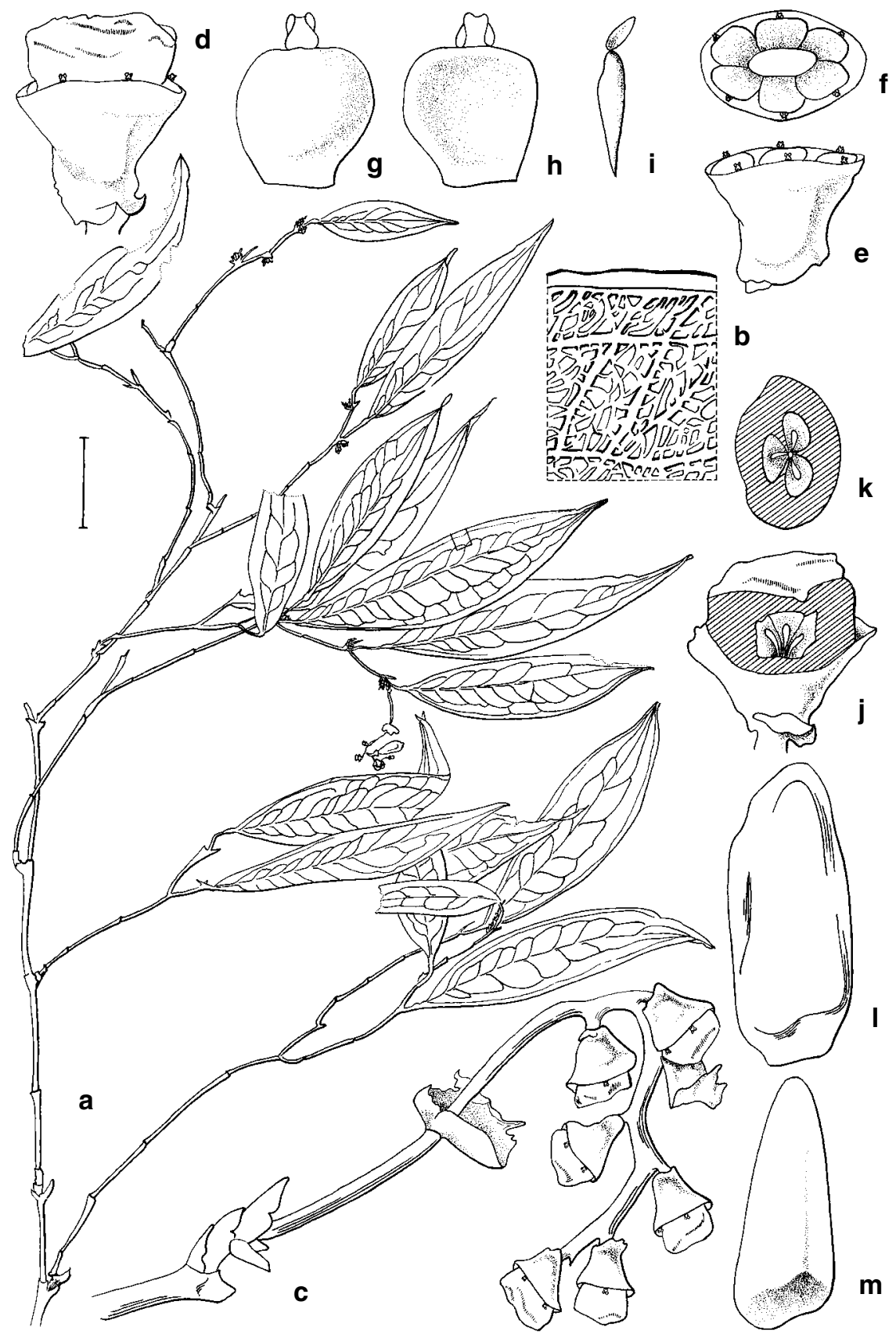

Fig. 50. Pedicellarum paiei. $\mathbf{a}$, fertile shoots; $\mathbf{b}$, venation detail; $\mathbf{c}$, inflorescence; $\mathbf{d}$, whole flower, side view; e, fused tepals, stamen just visible, side view; $\mathbf{f}$, fused tepals, stamens visible, top view; $\mathbf{g}$, stamen, inside view; $\mathbf{h}$, stamen, out view; $\mathbf{i}$, stamen, side view; $\mathbf{j}$, whole flower, ovary longitudinally sectioned; $\mathbf{k}$, ovary, transverse section; $\mathbf{l}$, berry, side view; $\mathbf{m}$, berry, rear view: a-m, Church et al. 1014. Scale bar: $\mathrm{a}=3 \mathrm{~cm} ; \mathrm{b}=1.7 \mathrm{~mm} ; \mathrm{c}, \mathrm{l}, \mathrm{m}=5 \mathrm{~mm} ; \mathrm{d}-\mathrm{f}, \mathrm{j}, \mathrm{k}=3.3 \mathrm{~mm} ; \mathrm{g}-\mathrm{i}=0.5 \mathrm{~mm}$. 
From the scattered provenances of available collections it is quite probable that Pedicellarum paiei is not a rare species and is more likely simply overlooked.

[A combination for this species in Pothos has been made by Grayum (1984: 634; 1992) but was not effectively published; the argumentation presented by Grayum is based on (misidentified) P. oliganthus.]

Other specimens examined: BORNEO: SARAWAK: 1st Div., Matang N.P., Ulu Sg. Rayu, Ismawi $S 54080$ (K, KEP, L, SAN, SAR, US); 1st Div., Bau, Kubah N.P., ridge leading from main road, c, 2 km from park entrance, Boyce 782 (K, M, SAR); 1st Div., G. Matang, 'Native collector' 5178 (UCL). SABAH: Nabawan, Syt. Benawood, Sg. Maadun, Krispinus SAN 104271 (SAN); Sandakan, Ulu Sg. Pinangah, Lassan SAN 107216 (K, SAN). KALIMANTAN: W Kalimantan, Sintang, Bk. Baka N.P., along Sg. Ella, Church et al. 303 (A, BO, K); W Kalimantan, Sintang, HPH km 69-73, W of camp off main (new) logging road, Church et al. 1014 (A, BO, K); CE Kalimantan, W Kutai, no. 28, near Long Liah Leng, Endert 2942 (BO, K, L).

\section{Pothoidium}

Pothoidium Schott, Oesterr. bot. Wochenbl. 7 (1857) 70 \& Aroideae 6 (1856-1857) 26, t.57 \& Gen. Aroid. (1858) 96 \& Prodr. Syst. Aroid. (1860) 575-576; Engl. in A. \& C. DC, Monogr. Phan. 2 (1879) 94-95; Benth. \& Hook.f., Gen. Pl. 3(2) (1883) 999; Engl. \& Prantl, Nat. Pflanzenfam. T.2, Ab.3 (1889) 114-115; Engl. in Engl., Pflanzenr. 21 (IV.23B) (1905) 44-46, fig.18; Merr., Enum. Philippine Pl. 1 (1922) 174; Elmer, Leafl. Philippine Bot. 10(133) (1938) 3627; Mayo et al., Genera of Araceae (1997) 100, pl.7. - Type: Pothoidium lobbianum Schott.

Large, slender to robust, root climbing, homeophyllous, tough, fibrous lianes. Shoot system usually clearly differentiated into adherent, physiognomically monopodial (see Boyce 1998, Boyce \& Nguyen 1995, Boyce \& Poulsen 1994, Boyce \& Hay 1998, Boyce 2000, Hay 1995) non-flowering shoots and free, physiognomically monopodial pendent, flowering shoots; juvenile plants with leaves as for adults but much smaller and more congested; internodes (except at the beginning of branches) much longer than thick. Leaf blades simple, entire, narrowly lanceolate to broadly ovate, with reticulate venation, the primary lateral veins on each side of the midrib traversed by one or more intramarginal veins running \pm from the base and from about midway along the midrib to the apex, or first to the distal margins and then to the apex; petiole broad, flattened and lamina-like with a small apical articulation, the leaf resembling that of some Citrus. Inflorescences several to many, borne in a terminal branching system, lower inflorescences axillary to a foliage leaf, upper ones either subtended by a cataphyll or without a subtending leaf, peduncular axis slender, composed of one to several internodes, sometimes subtended by a prophyll, sometimes also bearing a cataphyll \pm halfway up. Spathe occurrence irregular, often absent, linear-lanceolate, widely spreading, margins usually revolute. Spadix apparently often functionally unisexual, cylindric, sessile to long-stipitate when subtended by spathe. Flowers apparently usually unisexual, sometimes bisexual, congested, with a perianth of 6 free tepals; male flowers with well developed anthers and apparently sterile ovary; female flowers with large fertile ovary and lacking stamens; stamens 3-6, free, number often varying on a single spadix, filaments broad, flattened, anthers extrorse, thecae short, ellipsoid, dehiscing by a broad slit; ovary 1-locular, ovule 1, anatropous on a sub-basal placenta; stigma discoid-hemispheric. Fruit a 1-seeded berry, individually distinct and large relative to size of spadix; seed large, exalbuminous, testa smooth; embryo macropodal. Pollen monosulcate, ellipsoid-oblong, medium-sized [mean $26 \mu \mathrm{m}$. (Grayum 1984, 1992)], exine reticulate, muri-psilate, apertural exine shallowly fossulate or verrucate. Chromosomes: $2 \mathrm{n}=24$ (Petersen 1989). 
Distribution - One species in the Philippines, Sulawesi, Maluku and Taiwan (Lanyu Island).

Habitat - Primary to disturbed lowland to hill forest on a variety of substrates including clays and volcanic-derived soils, 30-500 m altitude.

\section{Pothoidium lobbianum Schott}

Pothoidium lobbianum Schott, Oesterr. Bot. Wochenbl. 7 (1857) 70. - Type: Philippines, Luzon, Manila, Lobb s.n. (K, holo).

Slender to robust, high root-climbing liane. Shoot system well-differentiated into adherent, climbing shoots and free, lateral flowering branches; eocaul not observed; seedling with congested leaves similar in shape to adult, but with blade elliptic and as long as petiole, becoming progressively larger as shoot extends. Leaves mid-green above, slightly paler below, drying variously dull green to orange-brown; petiole $4-17.5 \times 0.4-2 \mathrm{~cm}$, greatly exceeding the blade in length, oblanceolate, distally rounded to truncate to auriculate; blade (0-)1-6 $\times 0.3-1.5 \mathrm{~cm}$, elliptic to narrowly triangularlanceolate, somewhat acute, base rounded to truncate; primary lateral veins very obscure, diverging at c. 30-40 , intramarginal veins nearly invisible, 2 (or 3) on each side of the midrib. Inflorescences several to many, borne in a terminal branching system on either the primary or subsidiary (in which instance primary inflorescence system often accompanied by two or more subsidiary systems) tips of long pendent shoots, branching system 9-41 cm in total length, lower inflorescences axillary to a foliage leaf, upper ones either subtended by a cataphyll or without a subtending leaf; peduncular axis slender to very stout, composed of one to several internodes, sometimes subtended by a prophyll, sometimes also bearing a cataphyll \pm halfway up; peduncle slender, 1-2 cm long. Spathe 2-3 $\times 0.2-0.4 \mathrm{~cm}, \pm$ lorate-lanceolate, spreading to slightly reflexed, greenish white. Spadix long stipitate to sessile; stipe 0-3.5 cm long; fertile portion 1-6 6 0.2-0.4 cm, slender to rather stoutly cylindrical, pale green. Flowers c. 1.3 $\mathrm{mm}$ diam., with 6 free tepals and 6 stamens. Infructescences with many berries; fruit $0.8-1.1 \times 0.5-1 \mathrm{~cm}$, globose-oblong to obovoid, bright red when ripe; seeds ellipsoid, $\mathrm{c}$. $1 \mathrm{~cm} \times 6 \mathrm{~mm}$, mid-brown. - Fig. 51 .

Distribution - As for genus.

Habitat - As for genus.

Note - Unique in the Araceae in the structure of the inflorescence system; fertile material is unlikely to be confused with any other species. Nevertheless, Pothoidium lobbianum is not infrequently collected as Pothos cylindricus, a species with strikingly similar vegetative appearance that occurs sympatrically with Pothoidium lobbianum in the Philippines.

Other specimens examined: PHILIPPINES: Luzon, Cagayan Prov., Callao vicinity of Peñablanca, Adduru 65 (A, MO); Luzon, Cagayan Prov., Littoc, vicinity of Peñablanca, Adduru 114 (A, MO); Luzon, Cagayan Prov., Laguna, vicinity of Peñablanca, Adduru 199 (A, K, MO, US); Luzon, Cagayan Prov., Peñablanca, Bolster 123 (MO); Luzon, Bataan Prov., Lamao River, Mt Mariveles, Borden FB 3053 (K, US); Luzon, Isabela Prov., Palanan, San Isidro, Sierra Madre Mts. E foothills, NW of Diago, c. 1.5 km SSE of Palanan Point, Leonardo Co 3512 (A, K, KEP, L, PNH, US); Luzon, Camarines Sur Prov., Mt Isarog, Convocar 2901 (MO); Luzon, Quezon N.P., Croat 52994 (MO); Luzon, Benguet Prov., Kias, Elmer 6435 (K, US); Mindanao, Agusan Prov., Cabadbaran (Mt Urdaneta), Elmer 13444 (BM, K, MO, US); Luzon, Sorsogon Prov., Irosin (Mt Bulusan), Elmer 14429 (BM, K, MO, US); Luzon, Laguna Prov., Los Baños (Mt Maquiling). Elmer 17887 (K, MO, US); Mindoro, Mindoro Orientale, Pola River, Fénix BS 28231 (PNH); Luzon, Apayao, Gutierrez et al. PNH 117267 (BM); Luzon, Haenke s.n. (B); Luzon, Jager s.n. (B); Luzon, Rizal, Montalban, Loher 2462 (K, US); Luzon, Rizal Prov., Montalban, Loher 7046 (K); Luzon, Rizal Prov., Montalban, Loher 7047 (K, US); Biliran, McGregor BS 18538 (MO); Luzon, Quezon Prov., Hinabaan, Guinayangan, Mendoza 


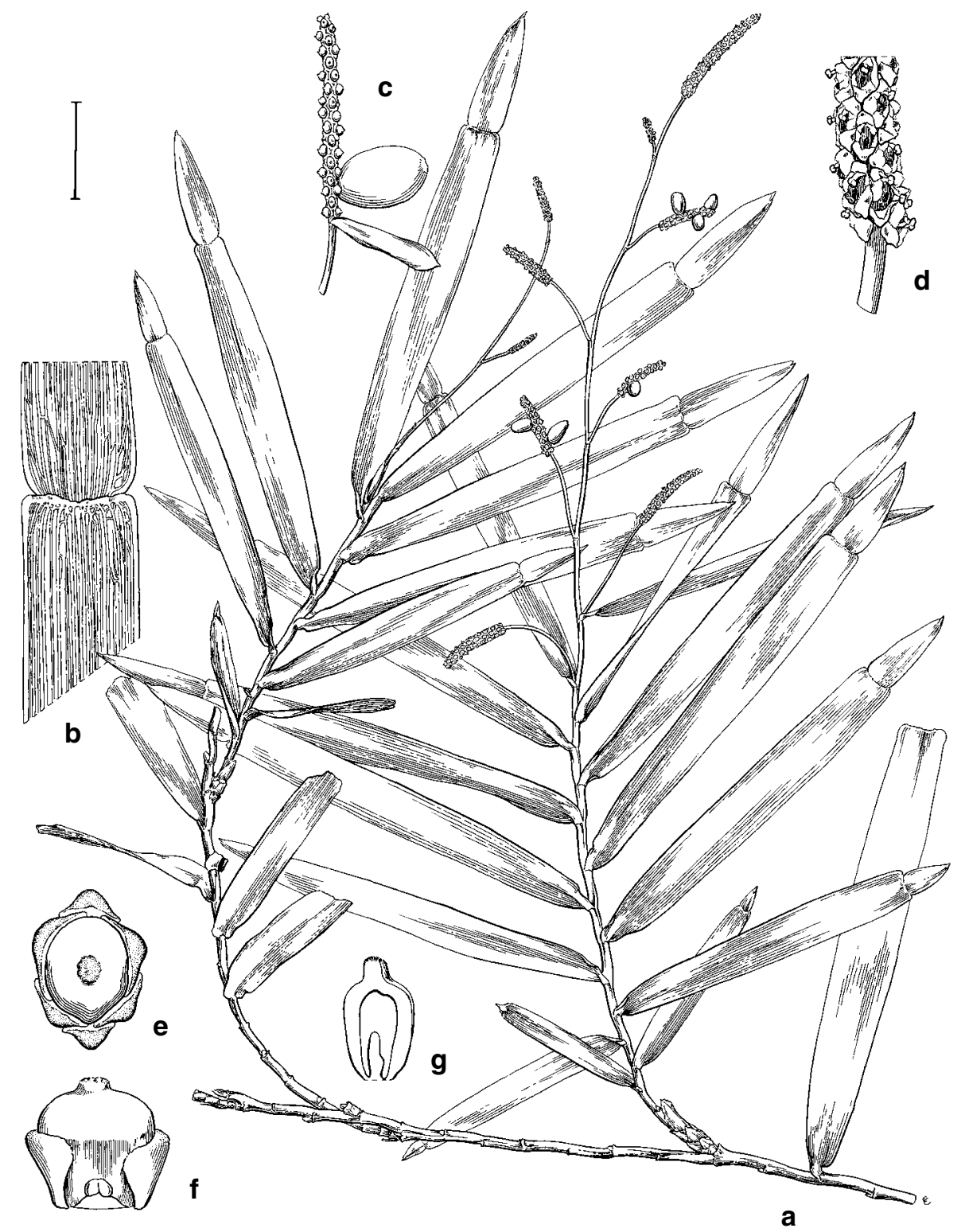

Fig. 51. Pothoidium lobbianum. a, habit; $\mathbf{b}$, detail of leaf blade and petiole venation; $\mathbf{c}$, infructescence; $\mathbf{d}$, detail of basal portion of spadix; e, flower, top view; f, flower,one tepal removed; $\mathbf{g}$, gynoecium, longitudinal section. a-b, de Vogel 3866 (K); c: Loher 7047 (K); d, Merrill 2293 (K \& Kew spirit collection 58025); e-g, Herb. Lugd. Bat. (K). Scale bar: $\mathrm{a}=3 \mathrm{~cm} ; \mathrm{b}=1 \mathrm{~cm} ; \mathrm{c}=1,3 \mathrm{~cm} ; \mathrm{d}=4 \mathrm{~mm}$; $\mathrm{e}-\mathrm{g}=0.7 \mathrm{~mm}$. 
PNH 97846 (K, PNH); Luzon, Tanay, Morong, Merrill 2293 (K, US); Albay Prov., Mt Malinao Tuui, Mucado 1670 (K); Samar, $4 \mathrm{~km} \mathrm{~W}$ of Bagacay Barrio, about $20 \mathrm{~km} \mathrm{~W}$ of Wright, along Ulat River, Nicolson 802 (B, K, US); Negros, Negros Orientale, Mt Canlaon, above Canlaon, Nicolson 831 (US); Luzon, Rizal Prov., Bosoboso, Ramos BS 1015 (US); Luzon, Batangas Prov., Ramos BS 1831 (BM, MO); Samar, Catubig River, Ramos BS 24304 (US); Batan, Batanes Prov., Mt Iraya, Ramos BS 80257 (K); Luzon, Cavite Prov., Ramos \& Deroy BS 22535 (K, US); Mindoro, Mindoro Orientale, Pola River, Reed PNH 170249 (PNH); Luzon, Camarines Norte, Basud, Tuaca, Mt Nilisan, Reynoso et al. PPI 1228 (PNH, US); Luzon, Camarines Norte, Basud, Tuaca, Mt Nilisan, Reynoso et al. PPI 1305 (PNH, US); Luzon, Camarines Sur Prov., Bicol N.P., c. 1 km from Mapolidan, Sinclair 9530 (E, PNH, SING); Luzon, Bataan Prov., Morong, tractor road from Morong to Mt Natib, above Refugee Camp and Morong River, Soejarto et al. 7771 (K, MO, PNH); Luzon, Laguna Prov., Los Banos, Steiner 512 (PNH, US); Luzon, Sorsogon Prov., Mt Bulusan, Sulit PNH 3630 (MO); Mindoro, Mt Yagaw, E slope, Sulit $\mathcal{E}$ Conklin PNH 17686 (BM, K); Luzon, Rizal Prov., Bosoboso, Morong, Vidal 3965 (K); Mindanao, Butuan, Weber 1049 (US); Leyte, Wenzel 510 (BM, E, MO, US); Leyte, Wenzel 992 (BM, MO); Surigao, Wenzel 3013 (K, MO); Mindanao, Butuan, Wester BS 19355 (US); Luzon, Bataan Prov., Lamao River, Mt Mariveles, Whitford 503 (K, US); Mindanao, Davao Prov., Santa Cruz, Williams 2936 (US). SULAWESI: Minahassa, G. Tetawiran, Alston 16403 (BM, BO); Sulawesi Utara, $220 \mathrm{~km}$ W of Manado, $50 \mathrm{~km}$ inland from Pangi, on Sg. Ilanga, Burley et al. 3599 (A, BO, E, K, KEP, MO, US); Sulawesi Utara, $220 \mathrm{~km} \mathrm{~W}$ of Manado, $50 \mathrm{~km}$ inland from Pangi, tributary of Sg. Ilanga, Burley et al. 3738 (A, BO, K, US); Sulawesi Utara, Bolaang Mongondo, between Pinogaluman and Pindol, de Vogel 2552 (BO, L, US); Sulawesi Utara, Bolaang Mongondow, Dumoga Bone N.P., Toraut Dam, along Toraut River, de Vogel E Vermeulen 6599 (BO, K, L, US); Minahassa, Koorders 16135 (BO, K, L); Minahassa, Koorders 16140 (BO, K, L); Sulawesi Utara, Dumoga Bone N.P., Toraut, beside Sg. Tumpah, Martin s.n. (BM); Sulawesi Utara, Dumoga Bone N.P., Whitmore E Sidiyasa 3422 (BO, K). MALUKU: N Maluku, Akelamo, N of Djailolo, Alston 16897 (BM, BO); N Maluku, Halmahera, G. Jailolo, de Vogel 3499 (BO, K, L, MO); N Maluku, Bacan Is., near Amasing Kali, de Vogel 3866 (BO, $\mathrm{K}, \mathrm{L}, \mathrm{MO}$ ).

\section{Insufficiently known species}

44. Pothos longus Ridl., J. Straits Branch Roy. Asiat. Soc. 44 (1905) 188. - Type: Malaysia, Sarawak, $1^{\text {st }}$ Div., four miles from Kuching, Haviland 934 (not found).

Note - There is no material of this collection in SING, and we have been unable to locate a specimen in any of the herbaria to which Haviland is supposed to have sent duplicates. Ridley's description of $P$. longus implies that it is very close to, if not identical with, P. mirabilis; if the latter proves to be true, the name P. longus has priority.

\section{Doubtful species}

Pothos sanderianus Hort., Gard. Chron. n.s. 21 (1884) 711.

Pothos nitens W. Bull, Cat. 1887 (1887) 11.

The descriptions of both are too vague to enable identification and it is not even clear that they are of Pothos plants; it is possible that they are Piperaceae. No types were cited and no authentic material has been located.

\section{Newly excluded species}

\section{Pothos latifolius L.}

Pothos latifolius L. in Stickman, Herb. Amboin. (1754) 25. [- Pothos macrostachyus Moritzi, Syst. Verz. (1846) 83; Schott, Prodr. Syst. Aroid. (1860) 572, nom.superfl. pro $P$. latifolius L.]. - Pothos tener Schott, Aroideae 1 (1856-7) 24 \& Prodr. Syst. Aroid. (1860) 572; Engl. in A. \& C. DC, Monogr. Phan. 2 (1879) 94, nom. illeg. non Wall. (1820). Type: Adpendix arborum Rumph., Herb. Amb. 5 (1747) t. 181, fig.1, see below. = Piper sp. (Piperaceae). 
Linnaeus cited Rumphius' plate of Adpendix arborum (Herb. Amb. 5, t. 181, fig. 1 \& 2) in its entirety in publishing $P$. latifolius. However, and contrary to the interpretation by Merrill (1917), the plate depicts two distinct species. Rumphius' Fig. 1 shows an inflorescence with no spathe and none of the distinctively conspicuous Pothos fruits. The absence of distinct fruits suggests that the inflorescence, if of Pothos, is at anthesis, in which case a spathe is to be expected. Consequently we came to suspect that the plant depicted is not Pothos. More conclusively, Rumphius described the fruit [sic] of this plant as being finger-like and $4-5$ inches long. This firmly places this plant outside Pothos, but is compatible with the aggregate infructescences of some Piper species, in which the habit is often similar to that of Pothos. (Leaf venation is quite different, but it is not depicted in the illustration.) We therefore exclude Fig. 1 from Araceae. In publishing Pothos tener Wallich (see earlier) for Roxburgh's illegitimate Pothos gracilis (non Aublet), only figure 2, which clearly is Pothos, was explicitly cited. In doing so Roxburgh implicitly lectotypified Linnaeus' P. latifolius on figure 1 of Rumphius' plate, here confirmed. We therefore exclude Pothos latifolius L. from Araceae.

Publishing Pothos macrostachyus, Moritzi cited Linnaeus' type concept of P. latifolius as a synonym. Pothos macrostachyus is here treated as a homotypic synonym of $P$. latifolius L. and excluded from Araceae.

\section{Previously excluded species}

Pothos argenteus W.Bull $=$ Scindapsus pictus Hassk.

Pothos argyraeus Engl. = Scindapsus pictus Hassk.

Pothos aureus Linden \& André = Epipremnum pinnatum (L.) Schott 'Aureum'

Pothos bifarius Wall. ex Hook.f. = Rhaphidophora korthalsii Schott

Pothos caudatus Roxb. = Epipremnum pinnatum (L.) Engl.

Pothos celatocaulis N.E.Br. = Rhaphidophora korthalsii Schott

Pothos cuscuaria Aubl. = Scindapsus cuscuaria (Aubl.) C. Presl

Pothos decursivus Roxb. $=$ Rhaphidophora decursiva (Roxb.) Schott

Pothos decursious Wall. = Epipremnum pinnatum (L.) Engl.

Pothos enderianus N.E.Br. = Scindapsus treubii

Pothos giganteus Roxb. $=$ Epipremnum giganteum (Roxb.) Schott

Pothos glaucus Wall. = Rhaphidophora glauca (Wall.) Schott

Pothos hederaceus Zoll. \& Moritzi = Scindapsus hederaceus Miq.

Pothos heterophyllus Roxb. = Lasia spinosa (L.) Thwaites

Pothos lasia Roxb. = Lasia spinosa (L.) Thwaites

Pothos miniatus Zipp. ex Schott = Amydrium zippelianum (Schott) Nicolson

Pothos monopetalus Reinw. ex Miq. = Anadendrum microstachyum (de Vriese \& Miq.) Backer \& Alderw.

Pothos obliquus Wall. ex Hook.f. = Rhaphidophora hongkongensis Schott?

Pothos officinalis Roxb. = Scindapsus officinalis (Roxb.) Schott

Pothos paucinervius Ridl. = Anadendrum sp.

Pothos peepla Roxb. $=$ Rhaphidophora peepla (Roxb.) Schott 
Pothos pertusus Roxb. $=$ Rhaphidophora pertusa (Roxb.) Schott

Pothos pinnatifidus Roxb. = Epipremnum pinnatum (L.) Engl.

Pothos pinnatus L. = Epipremnum pinnatum (L.) Engl.

Pothos pipla Schult. $=$ Rhaphidophora peepla (Roxb.) Schott

Pothos spinosus (L.) Buch.-Ham. ex Wall. = Lasia spinosa (L.) Thwaites

Pothos wallichii Steud. $=$ Rhaphidophora glauca $($ Wall.) Schott

\section{Acknowledgments}

Thanks are due to Emmanuel Papadopoulos, Linda Gurr, Helen Greenop, Kathleen McKeehan and Eleanor Catherine for skillfully executing the illustrations that accompany this article, and to Dr Alan Radcliffe-Smith for the Latin translations of the diagnoses. We would like to express our thanks to the following herbaria and institutions for the loan of material and for their hospitality during visits: $\mathrm{A}, \mathrm{AAU}, \mathrm{B}$, BISH, BKF, BM, BO, BRI, BRUN, BSIP, C, CAL, CANB, E, FI, G, K, KEP, K-WAL, KYO, L, LAE, LE, MAN, MEL, MO, MSC, NSW, P, PNH, QRS, SAI, SAN, SAR, SING, SP, UCL, UKMB, UKMS, UPM, UPNG, US. Additionally we wish to express our thanks to the following people for their invaluable assistance and collaboration during fieldwork: in Peninsular Malaysia, Dr Saw Leng Guan and Dr Lilian Chua (KEP); in Brunei Darussalam and Sabah, Dr Wong Khoon Meng (formerly BRUN and SAN); in Sabah, Dr Jamili Nais (SP), Anthony Lamb, Jain Linton (Taman Pertanian Sabah); in Sarawak Dr Abang Mohtar (SAR). Lastly we thank Dan Nicolson (US) and members of the Telopea editorial committee for critical comment on the manuscript.

\section{References}

Blanc, P. (1977a) Contribution à l'étude des Aracées. I. Remarques sur la croissance monopodiale. Rev. gén. Bot. 84: 115-126.

Blanc, P. (1977b) Contribution à l'étude des Aracées. II. Remarques sur la croissance sympodiale chez l'Anthurium scandens Engl. le Philodendron fenzlii Engl. et le Philodendronspeciosum Schott. Rev. gén. Bot. 84: 319-331.

Blanc, P. (1978) Aspects de la ramification chez des Aracées tropicales. (Thèse pour l'obtention du Diplôme de Docteur de 3é. cycle à l'Université Pierre et Marie Curie: Paris).

Blanc, P. (1980) Observations sur les flagelles des Aracées. Adansonia, sér. 2, 20 (3): 325-338.

Boyce, P.C. (1998) The genus Epipremnum Schott (Araceae-Monsteroideae-Monstereae) in West and Central Malesia. Blumea 43: 183-213.

Boyce, P.C. (2000) The genus Pothos (Araceae-Pothoideae-Potheae) of Thailand and Indochina. Blumea 48: 147-204.

Boyce, P.C. \& Hay, A. (1998) Diversity in shoot architecture in Pothos (Araceae: Pothoideae): Observations towards a new infrageneric classification. Pp. 51-58 in Dransfield, J., Coode, M.J.E. \& Simpson, D.A. (eds) Plant Diversity in Malesia III. Proceedings of the Third International Flora Malesiana Symposium 1995. (Royal Botanic Gardens: Kew).

Boyce, P.C. \& Nguyen, D.V. (1995) Pothos grandis (Araceae: Pothoideae) described and validated and architectural notes on Pothos subgenus Pothos. Kew Bull. 50(4): 753-759.

Boyce, P. \& Poulsen, A.D. (1994) Notes on Pothos insignis (Araceae: Pothoideae). Kew Bull. 49: $523-528$.

Croat, T.B. (1990) Ecology and life forms of Araceae. Aroideana 11(3-4): 1-55.

Engler, A. (1879). Araceae. Pp. 1-681 in A. \& C. de Candolle (eds.), Monographiae Phanerogamarum. Vol. 2. (Masson: Paris).

Engler, A. (1905) Araceae-Pothoideae. In Engler, A. (ed.), Pflanzenreich 21 (IV.23B): 1-330.

Grayum, M.H. (1984) Palynology and Phylogeny of the Araceae. (University Microfilms International: Ann Arbor, Michigan). 
Grayum, M.H. (1992) Comparative external pollen ultrastructure of the Araceae and putatively related taxa. Monogr. Syst. Bot. Missouri Bot. Gard. No. 43. (Missouri Botanical Garden: St.Louis).

Hallé, F., \& Oldemann, R.A.A. \& Tomlinson, P.B. (1978) Tropical Trees and Forests; An Architectural Analysis. (Springer: Berlin).

Hay, A. (1995) The genus Pothos L. (Araceae-Potheae) in New Guinea, Solomon Islands and Australia. Blumea 40: 397-419.

Li, H. (1979) Araceae, Lemnaceae. Pp. 1-242 in Wu, C.Y. \& Li, H., Fl. Reip. Pop. Sinicae vol. 13 (2). (Beijing).

Linnaeus, C. (1753) Species plantarum ed. 1. Stockholm.

Linnaeus, C. (1763) Species plantarum ed. 2. Stockholm.

Madison, M. (1977) A revision of Monstera (Araceae). Contrib. Gray. Herb. 207: 3-100.

Mayo, S.J., Bogner, J. \& Boyce, P.C. (1997) The Genera of Araceae. (Royal Botanic Gardens: Kew).

Nicolson, D.H. (1988) Araceae. Pp. 17-101 in Dassanayake, M.D. \& Fosberg, F.R. (eds), A revised Handbook to the Flora of Ceylon Vol. 6. (Balkema: Rotterdam).

Petersen, G. (1989) Cytology and systematics of the Araceae. Nordic J. Bot. 9: 119-166.

Putz, F.E. \& Holbrook, N.M. (1986) Notes on the natural history of hemi-epiphytes. Selbyana 9: 61-69.

Schimper, A.F.W. (1903) Guilds in Plant-geography upon a physiological basis, part 2, ch. 2, pp. 192-206. (English translation by W.R. Fisher, revised and edited by Groom, P. \& Balfour, I.B.) (Oxford: Clarendon Press).

Schott, H.W. (1832) Araceae. Pp. 16-22 in Schott, H.W. \& Endlicher, S., Meletemata Botanica. (C. Gerold: Vienna).

Schott, H.W. (1856-1857) Aroideae. (C. Gerold, Vienna).

Schott, H.W. (1860) Prodromus systematis Aroidearum. 602 pp. (Typis congregationis mechitharisticae: Vienna).

Sivadasan, M. (1982) Taxonomic study of Araceae of South India. 533 pp. (Unpublished Doctoral Thesis, University of Calicut: Kerala).

Strong, D.R. \& Ray, T.S. (1975) Host tree location behavior of a tropical vine (Monstera gigantea) by skototropism. Science 190: 804-806.

Suresh, C.R., Sivadasan, M. \& Manilal, K.S. (1983) A commentary on Rheede's Aroids. Taxon 32: $126-132$.

Manuscript received 22 January 2001

Manuscript accepted 13 August 2001 


\section{Index of Exsiccatae}

\begin{tabular}{|c|c|c|}
\hline Pothos scandens $=\mathbf{1}$ & Pothos barberianus $=\mathbf{1 6}$ & Pothos laurifolius $=\mathbf{3 1}$ \\
\hline Pothos clavatus $=\mathbf{2}$ & Pothos longivaginatus $=\mathbf{1 7}$ & Pothos brassii $=32$ \\
\hline Pothos gracillimus $=\mathbf{3}$ & Pothos lancifolius $=\mathbf{1 8}$ & Pothos insignis $=\mathbf{3 3}$ \\
\hline Pothos hellwigii $=4$ & Pothos philippinensis $=\mathbf{1 9}$ & Pothos cuspidatus $=\mathbf{3 4}$ \\
\hline Pothos junghuhnii = 5 & Pothos englerianus $=\mathbf{2 0}$ & Pothos polystachyus $=\mathbf{3 5}$ \\
\hline Pothos macrocephalus $=\mathbf{6}$ & Pothos atropurpurascens $=\mathbf{2 1}$ & Pothos falcifolius $=36$ \\
\hline Pothos vertseegii $=7$ & Pothos kingii $=\mathbf{2 2}$ & Pothos beccarianus $=\mathbf{3 7}$ \\
\hline Pothos zippelii $=\mathbf{8}$ & Pothos salicifolius $=\mathbf{2 3}$ & Pothos curtisii $=\mathbf{3 8}$ \\
\hline Pothos papuanus $=\mathbf{9}$ & Pothos brevivaginatus $=\mathbf{2 4}$ & Pothos luzonensis = 39 \\
\hline Pothos longipes $=\mathbf{1 0}$ & Pothos wallichii $=\mathbf{2 5}$ & Pothos motleyanus $=\mathbf{4 0}$ \\
\hline Pothos cylindricus $=\mathbf{1 1}$ & Pothos volans $=\mathbf{2 6}$ & Pothos oliganthus $=\mathbf{4 1}$ \\
\hline Pothos tener $=\mathbf{1 2}$ & Pothos mirabilis $=\mathbf{2 7}$ & Pedicellarum paiei $=\mathbf{4 2}$ \\
\hline Pothos dolichophyllus $=\mathbf{1 3}$ & Pothos oxyphyllus $=\mathbf{2 8}$ & Pothoidium lobbianum $=\mathbf{4 3}$ \\
\hline Pothos ovatifolius $=\mathbf{1 4}$ & Pothos inaequilaterus $=\mathbf{2 9}$ & \\
\hline Pothos leptostachyus = $\mathbf{1 5}$ & Pothos brevistylus $=\mathbf{3 0}$ & \\
\hline
\end{tabular}

Aban $\mathcal{E}$ Saikeh SAN 79445 = 21; Aban et al. SAN $66890=27$; Achmad $375=\mathbf{1}, 1683=\mathbf{1 4}$ $1816=1$; Adduru 65, 114, 43, 199 = 43; Aet $\mathcal{E}$ Idjan 187 = 9, 841 = 36; Agama 664 = 27; Ahmad E Shukor 527 = 38; Ahmad E Sidek SA $638=6$; Ajoeb $486=28$; Alcacid PNH 6043 = 33; Alcasid et al. PNH $1660=39 ;$ Alston $14510=15,15566=1,15831=12,16403,16897$ = 43; Alvins $106=38 ;$ Anderson S 26848, S $31901=33 ;$ Anderson et al. S 27551 = 33; Anon. $B W 9806=4 ;$ Anon. BSIP $13858=4$ or 8; Anon. NGF $16403=4 ;$ Anon. NGF 31973 = 7; Anon. NGF 34132 = 7; Anon. LAE 52888 = 36; Anon. LAE $58597=8$; Anon. LAE $62112=$ 9; Anon. KEP 78970 = 16; Asdat 70 = 28; Ashton 13384, S 18212 = 16; Atasrip 238 = 36; Awa E P.C. Yii S $46634=37 ;$ Awa $\mathcal{E}$ Paie $S 45642=26$

Backer $1276=$ 5, $1875=\mathbf{1 2}, 7457,7499,17013,23376=$ 5; Backhouse s.n. $=\mathbf{1 0}$; Bailey s.n. $=$ 10; Bakhuizen van den Brink $4057=5,4216=28,4910=5,5689,6122=28$; Barbon et al. PPI 8141 = 13; Barnes FB 369 = 19; Bartlett 8450 = 38; Bateson $15=9$; Batten Pooll s.n. $=$ 5; Beaman $8361=\mathbf{2 1}, 8463=\mathbf{1 7}, 10089=\mathbf{3 3}, 10129=\mathbf{1}$; Beccari p.p. s.n. $=\mathbf{8}$, p.p. $16=\mathbf{9}$, p.p. $329=\mathbf{2}$, p.p. $487=\mathbf{2}$, p.b. $953=\mathbf{3 3}$, p.b. $1699=\mathbf{3 7}$, p.b. $3984=\mathbf{3 0}$, Beer's collectors BSIP 6496 = 9; Beguin 2269 = 8; Beumee 534, 722 = 5; Blake 9807, 12686, 15253, 15383, 15389, 19710, 19755, $21595=\mathbf{1 0}$; Bloembergen 4032, 4232, 4464, $4501=\mathbf{1 2}, 4570=\mathbf{1}$; Boden-Kloss s.n. $=$ 4, s.n. = 7, SFN $19293=16$; Boerlage $86=12$, s.n. = 5; Bolster $123=43 ;$ Boorman s.n. = 10; Boraule et al. BSIP $9052=71$ Borden FB $3053=43$; Boyce 304, $316=16,440=17,445=37$, $678=\mathbf{2 8}, 693=6,698=38,699=28,782=42,796=33,1094,1335=38,1336=28,1422$, $1423=14,1435,1437=16 ;$ Brass $2311=32,8242=4,12100=34,13030=36,13876=4$ or 8, 13943, $13958=\mathbf{9}, 20179=\mathbf{1 0}, 23440=9,25609,29186=4$; Brass \& White $278=\mathbf{3 2}$; Bray FRI $11776=\mathbf{1}$; Brongersma s.n. = 8; Brook $16876=12,10030=1,10699=33 ;$ Brunig 4805 = 16; Bünnemeijer 651 = 24; Burck s.n. = 1; Burkill s.n. = 14; Burkill \& Haniff SFN $17194=\mathbf{1}$; Burkill $\mathcal{E}$ Holttum FMS $7827=23$; Burley et al. $1558=6,2350=33,3569=12$, $3599,3738=43,4136=12 ; 4159=1$; Burtt $\mathcal{E}$ Woods $2475=16$; Buwalda $2907=5,4126=$ $\mathbf{1 2}, 5277=8 ; B W 13309=12,13337,13634,13717=36 ;$ Bynum $7500=12$ 
Callery s.n. = 1; Carr 11565, $11566=4,11729=12,12116=2,16162=12 ;$ Castro $7050=$ 21; Castro \& Arionuevo PNH 5721 = 11; Celis PNH $170403=\mathbf{1}$; Chai S $19456=16$, SAN 26034 = 1; Chelliah KEP 104636 = 38; Chew \& Corner RSNB $4977=37$; S.C. Chin $795=1$, $999=6$; Church et al. 303, $1014=42,1685=\mathbf{1 6}$; Clemens $8127=\mathbf{9}, 41333=4$; Clemens $\mathcal{E}$ Clemens $20017=\mathbf{2 5}, 21936=\mathbf{3 0}, 26542=\mathbf{3 3}, 26808=\mathbf{1}, 28514=\mathbf{1 7}, 31126,35003=\mathbf{2 1}$, $50710=17,261542=33 ;$ L. Co $3512=43,3548=19$; Conklin PNH $18976=1$; Conn E Kairo 147 = 9; Convocar PNH 2892 = 14, 2901 = 43; Coode $5378=1$, $7181=$ 21; Coode \& Katik NGF 32785 = 9; Coode et al. NGF 32724 = 4; Copeland $959=\mathbf{1}$; SFN 26102 = 38, SFN 29247, SFN 30994 = 6, SFN 32284, SFN $33493=\mathbf{1}$; Croat $52597=\mathbf{1 0}, 52781 B, 52848=\mathbf{1 2}, 52982$ $=14,52994=43,53004=29,53005=13,53184=33$; Croft $\&$ Lelean LAE $65463=12$; Cuming $682=\mathbf{1}, 908=\mathbf{2 9}, 914=\mathbf{1 1}, 1045=39 ;$ Curran $349=\mathbf{8} ; 3448=\mathbf{1 2}$, FB $5948=\mathbf{3 9}$, $F B 9656=\mathbf{1 3}, F B 12247=\mathbf{1 4}, F B 12250=\mathbf{1 1}$; Curtis $285=\mathbf{1}, 808=\mathbf{3 8}, 1327=\mathbf{2 5}, 2394=$ $\mathbf{1}, 2895=6,2987=38$

d'Albertis s.n. = 9; Dallachy s.n. = 10; Darbyshire $\mathcal{E}$ Hoogland $8077=$ 12; Davis 744 = 4; de Vogel $2552=43,2631=12,3126=8,3321=12,3499,3866=43,3957,4403=8,5061$, 5087 = 12; de Vogel $\mathcal{E}$ Vermeulen $6461=12,6599=43,6660=12 ;$ de Voogt 1303 = 5; de Wilde $\mathcal{E}$ de Wilde-Duyfjes $12315=15,20027$ = 28; Dewol $\mathcal{E}$ Karim SAN 77798 = 30; Didrichsen s.n. = 5; Djamhari $470=\mathbf{1 2}$; Docters van Leeuwen $9129=4,9661,11370=9$; J. Dransfield $6934=\mathbf{1 7}, 6944=\mathbf{3 0}, 6955=\mathbf{2 1}, 7169=37,7169 A=\mathbf{2 6}, 7269=\mathbf{3 0}, 7419=\mathbf{2 6}$; J. Dransfield E Madulid $1048=33 ;$ J. Dransfield E Saerudin $2164=33$; J. Dransfield et al. $7176,7405=\mathbf{1 6}, 7465=\mathbf{1 7}, 7537,7562=\mathbf{1 2} ;$ S. Dransfield $1282=31$

Edaño PNH 3382 = 1, PNH 6774 = 11, PNH 15426, PNH 37152 = 13, PNH 37154 = 11, PNH 37200, PNH 40154 = 14; Edaño \& Gutierrez PNH 37822 = 11; Edwards 228 = 1; Elbert $1816,3549=1,3787=12$; Elmer $6435=43,7240=11,9243=14,9268 a=13,9412=1$, $9618=\mathbf{1 4}, 13039=\mathbf{1 9}, 13444=\mathbf{4 3}, 14014=\mathbf{1 4}, 14429=\mathbf{4 3}, 15204=\mathbf{1 4}, 15854=\mathbf{1 3}, 17050$ $=19,17887=43,18005=1,20364=27 ;$ Elmer $21822=17 ;$ Endert $1761=33,2058,2362$ $=15,2942=42 ;$ Eyma $3173=8,3986=12$

Fa'arodo et al. BSIP $12164=$ 9; Fenix BS $28190=\mathbf{1 9}$, BS $28231=43$; Fidilis SAN $118616=$ 37, SAN 125457 = 16, SAN 125636, SAN 128252 = 37; Fitzalan s.n. = 10; Flecker $7071=32$; Floyd NGF 6969, NGF 7289 = 4; Forbes $407=5$, 2361 = 20; Foreman NGF 45669, NGF 52349 = 12; Foreman $\mathcal{E}$ Katik NGF 48482 = 36; Forman 240 = 12; Fox PNH 4722 = 1; Foxworthy BS 1640 = 19; Fraser s.n. = 10; Frodin UPNG $977=12$, NGF 26941 = 9, NGF 32077 = 36; Furtado SFN 33050 = 6; Furtado sub. Clemens \& Clemens $29155=17$

Gachalian PNH 33692 = 14; Gaerlan et al. PPI 5443 = 14; Gafui et al. BSIP $16967=12$, BSIP $17385=4$, BSIP 18828 = 12; Gambating SAN 114312 = 1; Gaudichaud s.n. = 1; George et al . S 42867 = 16; Gibot SAN 73770 = 21; Gideon LAE 77065 = 4; Gjellerup 512 = 9; Gonzalez 1667 = 1; Goodenough 5108 = 38; Grimes 1217 = 11; Gutierrez et al. PNH $117267=43$; Gwynne-Vaughn $488=16$

Hamzah 6 = 12; Haniff 2715, SFN 14301, SFN 15560, SFN 15994 = 1; Hardial \& Sidek 384 = 1; Hartley TGH 10479 = 4; 11897 = 4; Haviland 625, 938 = 16, 971 = 30; Hay 7053 = 32; Hay et al. $9030=1$; Hellwig $468=4$; Helms $1155=10$; Henderson s.n. = 28, FMS $11462=$ 18, SFN 19557 = 6 SFN 22411 = 22, SFN 23084 = 1, SFN $23835=$ 6, SFN 23844 = 1; Henty NGF 10663, NGF 41828 = 4; Henty $\mathcal{E}$ Frodin NGF $27249=4$; Hewitt A1 = 16; Hill s.n. $=$ 10; Hillebrand s.n. = 20; Hirano $\mathcal{E}$ Hotta 1011 = 21; Hollrung 637 = 9; Holttum $9727=38$, SFN 10912 = 28; Hoogland E Craven $10354=36,10404=7$; Horsfield s.n. = 1; Hose $582=$ 30; Hotta et al. 96 = 5; Hulstyn 23 = 1; Hume 89 = 1; Hunt $2400=12$; Hyland 3792, 5351, $8287=32$

Idjan $\mathcal{E}$ Mochtur 195, 265 = 12; Ijiri \& Niimura 632 = 9; Isles et al. NGF 31481 = 8; Ismawi $S 54080=42 ;$ Iwatsuki et al. $234,243=39$ 
Jackson s.n. $=\mathbf{1 0}, 8779=\mathbf{3 6}, 8986=\mathbf{8}, 9483=\mathbf{3 6}, 9577=4$; Jager s.n. $=43$; Jaheri sub . Nieuwenhuis $996=\mathbf{4 0} ; 1159=\mathbf{1 7}$; Jensen 256 = 8; Jimpin SAN 110325, SAN 119408 = 37; Johns $7657=4$, 7676, $8142=12,8764,9855,10489=4 ;$ NGF 47435 = 4; Joss 101 = 5; Junghuhn s.n. $=\mathbf{5}$

Kaap 87 = 5; Kaimal s.n. = 38; Kairo NGF 30841 = 4; Kajewski $1432=10,1607=12,1808$ = 8, 1813 = 12; Kalkman 3429 = 9; Kasim 122 = 1; Kasim E Zai 2994 = 38; Katik NGF 46898 = 8, NGF 56290 = 12; Keah SFN 32104, SFN 35282 = 6, SFN 35428 = 1; Kiew 3353 = 18; Kiew $\mathcal{E}$ Anthonysamy 2858 = 6; Kjellberg $2274=12$, Koie $\mathcal{E}$ Ølsen $1512=8 ; 1686=12$, Kokawa $\mathcal{E}$ Hotta $572=\mathbf{1 5}, 1300=\mathbf{1 1}$; Kollmann s.n. = 5; Koorders 16135, $16140=43,16151$, $16158,16177,16178 B=12,20433,20433 B, 20434=\mathbf{1}, 22061,22067=5,22539,23671 B=$ $\mathbf{1}, 24129=\mathbf{5}, 25016,26401 B, 29883=\mathbf{1}, 31167=\mathbf{5}, 35003 B=1,44108=5$; Kornassi 1028, $1391=8$; Kostermans $782=36,1092=36,10536=27,18699=1,19339,19349=5$; Kostermans et al. $375=\mathbf{5}$, sub UNESCO $192=\mathbf{2 5}$; Kotali et al. BSIP $11187=\mathbf{1 2}$; Krispinus SAN $104271=$ 42, SAN 121908 = 15; Kulip E Kantil SAN $133565=33$; Kunstler ('Dr King's Collector') $492=\mathbf{6}, 2723=\mathbf{2 2}, 3175=\mathbf{1 6}, 4327,6029=\mathbf{6}, 8274=\mathbf{1}, 2754,3012,3887$, $3903,4221,4236,8493=38$; Kuswata $\mathcal{E}$ Soepadmo $28=\mathbf{1}, 37=12$

Lagrimas PNH 9715 = 1; Lahaie 1061, 2215 = 1; Lam 955, 1036, 1041 = 9, 1566 = 34, 2427 $=\mathbf{1 2}, 3012=\mathbf{1 2}, 7624=\mathbf{1 0} ;$ Lanclasse $40=\mathbf{3 8} ;$ Lantoh SAN $87859=33 ;$ Laravita $\mathcal{E}$ Vinas LAE 62235 = 4; Lassan SAN 71259 = 21, SAN 107216 = 42; Latiff 104 = 1; Lauterbach 533 = 9, 932 = 12; Lavarack \& Ridsdale NGF 31092 = 4, NGF 31188 = 12; Leach NGF $34273=$ 9; Ledermann $6717 a, 7176=9,7411=3,8333,9001=7,11309=36,12696=35 ;$ Lee $S 45534$ = 41; Leichhard $246=10$; Lelean $\mathcal{E}$ Streimann NGF $52542=12 ;$ Leschnault s.n. $=1$; S.P. Lim et al. $576=15,584=33$; Lister Turner $22=4$; Loher $2457=19,2462=43,7033=13$, Loher $7036,7037=39,7044,7045=\mathbf{1}, 7046,7047=43$, Loher $7052=\mathbf{1 3}$, BS $13067=39$, BS 14778 = 1; Longman s.n. = 10; Lörzing 1041, 12349 = 1; Ludong $S 31842$ = 33; Lütjeharms 4457, $4759,4760=14$

Mabesa 836 = 29, BoF 24911 = 1; Mack 509 = 36; Madani SAN 107943 = 27; Madani $\mathcal{E}$ Saigol SAN 90156 = 21; Madani E Sigin SAN 111552 = 15; Madius SAN 49253 = 27; Madulid 6776 = 11, 6913 = 19; Madulid $\mathcal{E}$ Reynoso PNH 121125 = 11; Maikin $\mathcal{E}$ Lideh SAN 131103 = 11; Main 443 = 36, 460 = 9; Maingay 1538, 3041 = 38; Mamit S 32655 = 33; Mangyang 151 = 11; Mantor SAN $120314=37$, SAN $136116=15 ;$ Martin $\mathcal{E}$ Ismawi $S$ 36660 = 41; Mat s.n. = 38; Mauriasi et al. BSIP 8727, BSIP 8727, BSIP $11396=\mathbf{1 2}$, BSIP 13536 = 9, BSIP 14064, BSIP 14313, BSIP 14391, BSIP 15666, BSIP 15764 = 12; McDonald $\mathcal{E}$ Williams 3664 = 10; McGregor BS 18538 = 43, BS 32451 = 11; McKee 1911 = 8; MEDP 1269 = 22; Meijer 9368, 9410, 9463 = 12, SAN $21234=21$, SAN 43823, SAN 124380 = 16; Meijer E Kuripin SAN 51712 = 33; Meijer Drees 309, 324 = 9; Melville 3321A, 3389 = 10; Mendoza PNH 18238 = 13, PNH 41913 = 29, PNH 42452 = 14, PNH 97846 = 43; Mendoza $\mathcal{E}$ Convocar PNH $10237=13$, PNH $10533=29$; Merrill Sp. Blanco. $57=1$, Merrill $2293=$ 43, BA $2792=\mathbf{1}$, BS $7211=\mathbf{1 4}$, BS $9761=13 ;$ Millar NGF 9919, NGF $11798=4$, NGF 35464 = 9; Mk. Ar. 4957 = 38; Mogea 4442 = 16, $5367=12$; Mohtar et al. $S 49292$ = 16; MolesworthAllen 4116 = 6; Moore 132 = 10; Moriarty $873=10$; Moseley (Challenger Exped.) s.n. = 8; Motley 99 = 40, Motley $231=16,1194=1,1197=15$; Moulton's native collector 11 = 27; Mucado $1670=43 ;$ Muroh SAN $70601=16$

Nagle s.n. = 5; Nakisi E Babala BSIP $8240=$ 9, BSIP $8244=\mathbf{1 2}$; 'Native collector' BS $333=$ $\mathbf{1 7}, 1479=27, B S 1680=\mathbf{1}, B S 2176=37,5178=42 ;$ Nedi $524=8 ;$ Nengkat $248=31 ;$ Nernst s.n. $=\mathbf{1 0}$; Nicolson $699=\mathbf{1 3}$, Nicolson $707=\mathbf{1 1}, 708=\mathbf{2 9}, 713,720=\mathbf{1 1}, 748=\mathbf{1}, 758=\mathbf{1 3}$, $759=\mathbf{1 1}, 762=\mathbf{1 4}, 776,777,778,782=\mathbf{1 3}, 802=\mathbf{4 3}, 804=\mathbf{1 3}, 806=\mathbf{1 4}, 808=\mathbf{2 9}, 817=$ $\mathbf{1 1}, 819=\mathbf{1 4}, 821=\mathbf{1 3}, 831=\mathbf{4 3}, 840=\mathbf{1}, 849=\mathbf{5}, 884=\mathbf{1}, 1070,1071=\mathbf{3 8}, 1083=\mathbf{2 8}, 1168$ $=1,1174=23,1185=6,1283=1,1290=33,1381=10,1387,1388,1389=4,1415=4$ or 2, $1424,1447=12,1481,1482=4,1497=12,1519=4,1523=12,1538=4,1548=12$, $1561=\mathbf{9}, 1566,1572=\mathbf{1 2}, 1576=\mathbf{4}$ or $\mathbf{8}, 1579=\mathbf{4}, 1593=\mathbf{8} ;$ Nor FMS $31382=\mathbf{1}$, SFN $11145=\mathbf{1 8}$, SFN $11663=\mathbf{2 3}$, SFN $21753=\mathbf{1 4}$, SFN $32918=\mathbf{1 8} ;$ Nur $\mathcal{E}$ Kiah $7780=25$ 
Ogata KEP 110386 = 38; Ølsen 274 = 19, 355 = 33, 359, 540 = 14; Oro FB 30841 = 39

Paie S 16354 = 42; S 42082, S 42566 = 41; Paie E Yeo S 38478 = 16; Piper BS 481 = 11; Pleyte 723 = 2; Plowman $10747=10 ;$ Poore KL $1169=38 ;$ Porte s.n. = 1; Poulsen $147=17,180=$ 21, 183 = 33; Poulsen E Eri 174 = 37; Primack $S 42411$ = 37; Pulle 360 = 7; Puradyatmika $10441=4 ;$ Puruwansingsiti $\mathcal{E}$ Sanusi $30=12$

Rahim et al. SAN 93283 = 16; Rahmat Si Toroes $5439=\mathbf{5}$; Ramos BS 4 = 1, BS $1015=\mathbf{4 3}$, BS $1260=\mathbf{2 7}$, BS $1529=39$, BS $1831=43$, BS $13622=\mathbf{1}$, BS $14707=13$, BS $19367=\mathbf{1 4}$, BS $22132=13, B S 22143=11, B S 23708, B S 24125, B S 24144=13, B S 24304=43, B S$ $24474=\mathbf{2 9}$, BS $24475=\mathbf{1}$, BS $24543 B S 41549$ BS $42820=\mathbf{1 4}$, BS $80257=43 ;$ Ramos $\mathcal{E}$ Deroy BS $22535=43 ;$ Ramos $\mathcal{E}$ Edaño BS $26414=\mathbf{1 9}, B S 34031=\mathbf{1 9}, B S 44533=39$. BS $28549=14$, BS 49207 = 13, PNH 75424 = 14; Ramos \& Pascasio BS 34871 = 1; Reed PNH 170249 = 43; Regalado \& Sirikolo 730 = 12; Regalado E Takeuchi 1502 = 12; Reillo BS 15435 = 33, BS $19211=1$; Reynoso et al. PPI 1228, PPI $1305=43$; Richards $1452=33$; Ridley 2391 $=\mathbf{2 8}, 2953=\mathbf{1}, 6535,7248=\mathbf{3 8}, 8167=\mathbf{1}, 9014=\mathbf{1 6}, 9696,10318=\mathbf{3 8}, 11285=\mathbf{1 6}, 11420$ = 38, 14371, $14791=\mathbf{1}$; Ridley's collector s.n. = 38; Ridsdale SMHI $362=\mathbf{1 4}$; Ridsdale et al . ISU 556 = 19; Robinson Herb. Rumph. No. 116, Herb. Rumph. No. $117=12$, Pl. Rumph. Amboin. $118=\mathbf{1}$; Robinson $\mathcal{E}$ Johnson 86-151 = 10; Robinson et al. 86-105 = 10; Runikera et al. $B S I P 9916=\mathbf{9}$, BSIP $13073=\mathbf{1 2}$

Saimoendt 11 = 5; Sands $1169=\mathbf{1 2}, 6033=\mathbf{1}$, Sands $6270=\mathbf{1 2}$; Sands et al. 2687, $2778=\mathbf{1 2}$; Santos 4154 = 14; Sayers NGF $19641=4$; Schlechter 16391, 17686, 18353 = 9; Schodde 5617 = 10; Schodde $\mathcal{E}$ Craven $4042=\mathbf{1 2}$; Scortechini $56=\mathbf{1}, 116 \mathrm{~b}=\mathbf{6}, 576 \mathrm{~b}=\mathbf{1 8}, 621,621 \mathrm{~A}=\mathbf{2 5}$, $624 a, 675=38$, Scortechini $1137=1,1450=22$; Shah $\mathcal{E}$ Aban SAN $76765=1$; Shah et al. 3367 = 38; Sharpe 4534 = 10; Shea $\mathcal{E}$ Aban SAN 78765 = 1; Shea $\mathcal{E}$ Minjulu SAN $76257=$ 16; Shirley s.n. = 10; Sinclair $9530=\mathbf{4 3}$, SFN $39378=\mathbf{3 8}$, SFN 40354, SFN $40356=\mathbf{1}$; Sinclair E Edaño $9616=13$; Soedarsono $226=28,243=28,280=6$; Soejarto $\mathcal{E}$ Madulid $6117=33$; Soejarto et al. $7771=43,7823=14 ;$ Soenarko $316=12 ;$ S.P. Soon SAN $131673=$ 15; Steiner $512=43$; Stevens et al. $263=16$; Stone $14025=23,10387$ sub. LAE $53687=12$; Streimann NGF $28802=\mathbf{2}$, NGF $44401=12$, NGF $51738=\mathbf{7}$, NGF $52784=12$; Streimann $\mathcal{E}$ Fasavalu NGF 47741 = 4; Streimann $\mathcal{E}$ Kairo NGF $39265=12 ;$ Streimann $\mathcal{E}$ Katik LAE 51862 = 7; Suharno $189=8,229=1$; Sulit PNH $2623=\mathbf{1 4}$, PNH $3630=43$, PNH $6399=$ 39, PNH 7071 = 1; Sulit $\mathcal{E}$ Conklin PNH 17686 = 43; H.F. Sun $9953=28$; Symington 24246 $=28$

Takeuchi $5419=\mathbf{3 6} ; 7386=\mathbf{1 2}$; Taylor 263, $383=\mathbf{8}, 2164=\mathbf{1 2}$; Teysmann $8100=\mathbf{1}, 12766=$ 12; Townsend 102 = 9; Toxopeus 623 = 12; Tracy 14800 = 32; Treub s.n. = 1; Tuyuk \& Hassan SAN $117169=37$

UNESCO Limestone Exp. $317=\mathbf{1}$; Utteridge $108=\mathbf{1 2}, 309=\mathbf{4}, 311=\mathbf{3 6}, 391=12$

van Balgooy 3051, 4807 = 12; van Borssum Waalkes 1634 = 6; van der Pijl 100 = 5; van Harreveld $684=5$; van Royen $3153=\mathbf{2}, 4030=8,5252=2$; van Royen $\mathcal{E}$ Sleumer $7245=$ 36; van Steenis $456=5,610=28,12509 a=5$; Vendivil $\mathcal{E}$ Juan PNH $126215=33$; Veridinil $\mathcal{E}$ Regnoso PNH 121685 = 39; Versteeg 1782 = 7; Vidal 1950, 1989, 1990 = 1, 3965 = 43, 3966 = 1, 3967 = 39, 3969 = 14; Villan PNH 98071 = 29; Vink BW 15355 = 4; Vink $\mathcal{E}$ Vink BW 15295 = 4; von Mueller s.n. = 10; Vreeken-Buijs 70, $71=38$

Wade s.n. = 3, Wallich 4439A, 4439B = 25; Waterhouse 196-B, 196-B-B = 4, 432-B, 196C-B = 12, 302 = 9; Webb \& Tracey $5575=10,10855=32 ;$ Weber $1044=13.1049=43$; Webster $\mathcal{E}$ Hildreth $15087=4$; Weinland $284=\mathbf{1 2}$; Wenzel $22=\mathbf{1 3}, 265=\mathbf{1}, 357=\mathbf{2 9}, 387=\mathbf{1 1}, 510$, 992, $3013=43,3056=29 ;$ Wester BS $19355=43$; Whitford $341=19,503=43$; Whitmore BSIP 3910 = 12; Whitmore E Sidiyasa $3422=43$; Whitmore et al. $3662=8$; Widjaja $603=$ 12, 2511 = 4; Wilkes s.n. = 1; Wilkie $9540=33$; Williams $486=19,2936=43,2937=11$; Wirawan 444 = 1; Wisse s.n. = 1; Womersley NGF $43681=4 ;$ K.M. Wong $1488=26,1635$ 
= 1; Wray $2338=\mathbf{1 6}, 3277=\mathbf{2 2}, 3322,3332=\mathbf{1}, 4212,4235=\mathbf{1 6}, 4254=\mathbf{6}$; Wright $\mathcal{E}$ Ismawi $S 32296=37$

Yates 1333, $1764=5$; P.C. Yii $S 40139=37, S 43927=16, S 44544=1$; P.C. Yii $\mathcal{E}$ Jegong $S$ $45988=37$

Zainudin $1295=\mathbf{1 5}, 1882=\mathbf{1}, 2793=\mathbf{2 2}$; Zippel s.n. = 8; Zollinger $422=\mathbf{5}, 854 Z, 2275=$ $\mathbf{1}$; Zwickey $171,714=\mathbf{1 4}, 835=\mathbf{1 3}$ 


\section{Index to species}

Names in roman are accepted, names in italics are synonyms.

Batis hermarphoditus Blanco 462

Goniurus luzonensis C. Presl 457

Pedicellarum paiei M. Hotta ............. 556

Pothoidium lobbianum Schott 559

Pothos acuminatissimus Merr. 495

albertisii Engl. 483

angustifolius C. Presl 462

angustifolius Reinw. ex Miq.

atropurpurascens M. Hotta

auriculatus S.Y. Hu

australasicus F. Muell.

barberianus Schott

barberianus Schott var. wallichii (Hook.f.)

Ridl. 541

basilanensis Furtado 538

beccarianus Engl.

borneensis Furtado

brassii B.L. Burtt

brevispathus Ridl.

brevistilus Engl.

brevivaginatus Alderw.

brownii Domin

chapelieri Schott

clavatus auct. non Engl.

clavatus Engl.

cognatus Schott

cumingianus Schott

curtisii Hook.f.

cuspidatus Alderw.

cylindricus auct. non C. Presl

cylindricus C. Presl

decipiens Schott

dolichophyllus Merr. elegans Engl. 481

ellipticus Ridl. non Moon ex Miq. .... 515

engleri Furtado 511

englerianus Alderw. 511

exiguiflorus Schott ............................... 462

falcifolius Engl. \& K. Krause .......... 543

fallax Schott ......................................... 463

gracilis Roxb. ...................................... 490

gracillimus Engl. \& K. Krause ........ 469

grandispathus Ridl. ............................. 515

hellwigii Engl. ....................................... 471

hellwigii Engl. var. latifolius .............. 471

hermaphroditus (Blanco) Merr. .......... 462

horsfieldii Miq. ....................................... 463

hosei Rendle ........................................... 533

inaequalis Ridl. ..................................... 527

inaequilaterus (C. Presl) Engl. ........ 528

insignis auctt. non Engl. ..................... 491

insignis Engl. ......................................... 538

jacobsonii Alderw. ............................... 527

junghuhnianus Schott ......................... 474

junghuhnii de Vriese ......................... 474

kinabaluensis Furtado ......................... 506

kingii Hook.f. ..................................... 515

korthalsianus Schott .............................. 527

kunstleri Hook.f. ................................. 547

lancifolius Hook.f. .............................. 506

latifolius Hook.f. non L. ..................... 547

latifolius L. ........................................... 561

laurifolius P.C. Boyce \& A. Hay .... 533

ledermannii Engl. \& K. Krause ........ 479

ledermannii Engl. \& K. Krause var. ...........

caudatus Engl. \& K. Krause ............ 479

leptospadix de Vriese ........................... 462

leptostachyus Schott ......................... 498

leschenaultii Buchet .............................. 463 
longifolius C. Presl 462

longipedunculatus Engl. 462

longipedunculatus Ridl. 518

longipes Schott 485

longivaginatus Alderw. 503

longus Ridl. 561

lorispathus Ridl. 498

loureiroi ('loureirii') auctt. non Hook. \&

Arn. 486

luzonensis (C. Presl) Schott 550

macrocephalus Scort. ex Hook.f. .... 476

macrophyllus de Vriese 474

macrostachyusMoritzi 561

maingayi Hook.f. 547

melaleucoides Furtado 518

merrillii K. Krause 497

microphyllus C. Presl 462

mirabilis Merr. 523

motleyanus Schott 552

nigrescens Zipp. ex Miq. 481

nitens W. Bull 561

nosibeensis Buchet 463

oliganthus P.C. Boyce \& A. Hay .... 552

ovatifolius Engl. 497

ovatifolius Engl. var. simalurensis Alderw.

oxyphyllus Miq. 527

papuanus Becc. ex Engl. .................. 483

penicilliger Gagnep. ............................ 506

peninsularis Alderw. ........................... 547

peninsularis Elmer ............................ 508

philippinensis Engl. ........................... 508

polystachyus Engl. \& K. Krause .... 540

quinquevenosus Alderw. .................... 483

ridleyanus Furtado ............................ 515

roxburghii de Vriese ......................... 462

rumphii Schott 490 rumphii Schott var. dolichophyllus (Merr.)

Nicolson 495 rumphii Schott var. giganteus Engl. .. 491 salicifolius Ridl. ex Burkill \& Holttum 518

sanderianus Hort. ............................... 561

scandens L. ............................................ 461

scandens L. fm. angustior Engl. ........ 463

scandens L. var. cognatus (Schott) Engl. ..

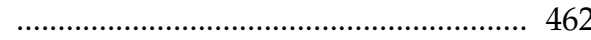

scandens L. var. falconeri Buchet ..... 463

scandens L. var. godefroyi Buchet ...... 463

scandens L. var. helferianus Engl. ...... 463

scandens L. var. javanicus de Vriese .........

scandens L. var. macrospadix Buchet .... 463

scandens L. var. sumatranus de Vriese ....... 462

scandens L. var. zeylanicus de Vriese ..462 scandens L. var. zollingerianus (Schott)

Engl. 462

sumatranus Engl. non Miq. .............. 511

sumatranus Miq. ............................... 527

tener Wall. ................................................ 490

tener Schott ....................................... 461

versteegii Engl. .................................... 479

volans P.C. Boyce \& A. Hay ............ 423

vrieseanus Schott ................................. 474

wallichii Hook.f. ............................... 521

zippelii Schott ..................................... 481

zollingeri Schott .................................. 462

zollingerianus Schott ......................... 462

Scindapsus arborum C. Presl ............. 490

inaequilaterus C. Presl ....................... 530

rumphii (Schott) C. Presl .................. 490

tener (Wall.) C. Presl ........................... 490 